
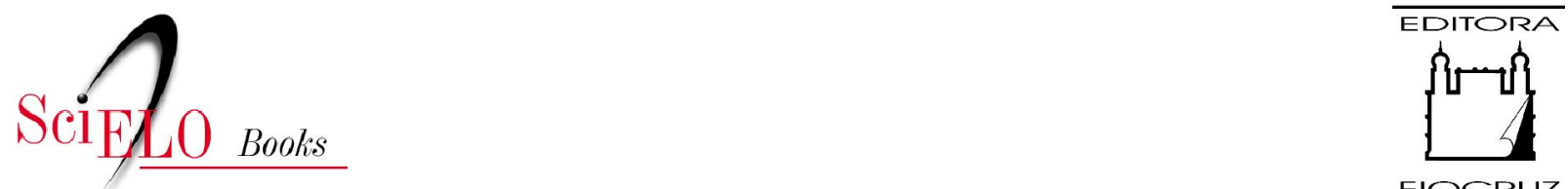

FIOCRUZ

\title{
Bioética e saúde
}

novos tempos para mulheres e crianças?

\author{
Fermin Roland Schramm \\ Marlene Braz \\ (orgs.)
}

SCHRAM, FR., and BRAZ, M., orgs. Bioética e saúde: novos tempos para mulheres e crianças? [online]. Rio de Janeiro: Editora FIOCRUZ, 2005, Criança, mulher e saúde collection, 274 p. ISBN: 978-85-7541-540-5. Available from: doi: 10.747/9788575415405. Also available in ePUB from: http://books.scielo.org/id/wnz6g/epub/schramm-9788575415405.epub

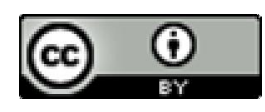

All the contents of this work, except where otherwise noted, is licensed under a Creative Commons Attribution $\underline{4.0 \text { International license. }}$

Todo o conteúdo deste trabalho, exceto quando houver ressalva, é publicado sob a licença Creative Commons Atribição 4.0.

Todo el contenido de esta obra, excepto donde se indique lo contrario, está bajo licencia de la licencia Creative Commons Reconocimento 4.0. 


\section{Bioética e Saúde NOVOS TEMPOS PARA MULHERES E CRIANÇAS?}




\section{FUNDAÇÃO OSWALDO CRUZ}

Presidente

Paulo Marchiori Buss

Vice-Presidente de Desenvolvimento Institucional, Informação e Comunicação

Paulo Gadelha

\section{EDITORA FIOCRUZ}

Coordenador

Paulo Gadelha

Conselho Editorial

Carla Macedo Martins

Carlos E. A. Coimbra Jr.

Charles Pessanha

Gilberto Hochman

Jaime L. Benchimol

José da Rocha Carvalheiro

José Rodrigues Coura

Luis David Castiel

Luiz Fernando Ferreira

Maria Cecúlia de Souza Minayo

Miriam Struchiner

Paulo Amarante

Paulo Gadelha

Vanize Macêdo

Coordenador Executivo

João Carlos Canossa P. Mendes

Coleção Criança, Mulher e Saúde

Editores Responsáveis: Suely Ferreira Deslandes

Maria Elizabeth Lopes Moreira 


\section{Bioética e Saúde NOVOS TEMPOS PARA MULHERES E CRIANÇAS?}

Fermin Roland Schramm Marlene Braz Organizadores




Copyright (c) 2005 dos autores

Todos os direitos desta edição reservados à

Fundaç̃̃o OSWALdo CRUZ / EdTTORA

Capa, Projeto Gráfico e Editoração Eletrônica:

Angélica Mello e Daniel Pose

Imagens da capa:

A partir de pinturas de Candido Portinari: A Greve (1950, óleo/tela, 55 x 46 cm, coleção particular, São Paulo, SP); Índia e Mulata (1934, óleo/tela, 72 x 50 cm, coleção particular, São Paulo, SP); Meninos com Carneiro (1959, óleo/madeira, 172 x 112 cm, coleção particular, São Paulo, SP); Meninos no Balanço (1960, óleo/tela, 61 x 49 cm, coleção particular, Rio de Janeiro, RJ); Moleques Pulando Cela (1958, óleo/tela, 59,5 x 72,5 cm, coleção particular, São Paulo, SP); Retrato de Maria Grávida (1939, óleo com areia/tela, 45,5 x 33,5 cm, coleção particular, Fortaleza, CE). Nossos agradecimentos a João Candido Portinari pela cessão de direitos de uso das imagens das obras nesta coleção.

Divulgação da Coleção Criança, Mulher e Saúde

Nina de Almeida Braga

Revisão:

Ana Lúcia Prôa

Janaina de Souza Silva

Catalogação-na-fonte

Centro de Informação Científica e Tecnológica

Biblioteca da Escola Nacional de Saúde Pública Sergio Arouca

B827b Schramm, Fermin Roland (org.)

Bioética e saúde: novos tempos para mulheres e crianças? / Organizado por Fermin Roland Schramm e Marlene Braz. Rio de Janeiro: Editora Fiocruz, 2005. 276 p. (Coleção Criança, Mulher e Saúde)

1. Bioética. 2. Saúde materno-infantil. 3. Alocação de recursos. I. Braz, Marlene (org.). II. Título.

CDD - 20.ed. - 174.957

2005

EDITORA FIOCRUZ

Av. Brasil, 4036 - 1o andar - sala 112 - Manguinhos

21040-361 - Rio de Janeiro - RJ

Tels: (21) 3882-9039 e 3882-9041

Telefax: (21) 3882-9006

e-mail: editora@fiocruz.br

http://www.fiocruz.br






\section{Autores}

Ana Paula Abreu Borges

Assistente social, especialista em Envelhecimento e Saúde do Idoso

Arnaldo Pineschi de Azevedo Coutinho

Pediatra, coordenador da Comissão de Bioética do Conselho

Regional de Medicina do Estado do Rio de Janeiro (CREMERJ)

Carlos Dimas Martins Ribeiro

Médico, doutor em Saúde Pública pela Escola Nacional de Saúde

Pública Sergio Arouca da Fundação Oswaldo Cruz (Ensp/Fiocruz), professor titular da Faculdade de Medicina da Universidade Severino Sombra

Fermin Roland Schramm (Organizador)

Bioeticista, doutor em Ciências/Saúde Pública pela Escola

Nacional de Saúde Pública Sergio Arouca da Fundação Oswaldo

Cruz (Ensp/Fiocruz), com pós-doutorado em Bioética pela

Universidade do Chile, pesquisador titular da Ensp/Fiocruz 
Gabriel Eduardo Schütz

Biólogo, mestre em Ciências/Saúde Pública pela Escola Nacional de Saúde Pública Sergio Arouca da Fundação Oswaldo Cruz (Ensp/ Fiocruz), doutorando em Ciências/Saúde Pública pela Ensp/Fiocruz

Heloisa Helena Barboza

Professora titular de Direito Civil da Faculdade de Direito da Universidade do Estado do Rio de Janeiro (Uerj), procuradora aposentada de Justiça do Estado do Rio de Janeiro

João Gonçalves Barbosa Neto

Mestre em Saúde da Criança pelo Instituto Fernandes Figueira da Fundação Oswaldo Cruz (IFF/Fiocruz), médico pediatra e geneticista, diretor de Assistência do Instituto Oswaldo Cruz de Seguridade Social da Fiocruz (FioPrev)

José Luiz Telles

Médico, doutor em Ciências/Saúde Pública pela Escola Nacional de Saúde Pública Sergio Arouca da Fundação Oswaldo Cruz (Ensp/ Fiocruz), pesquisador associado da Ensp, coordenador do Comitê de Ética em Pesquisa da Fundação Oswaldo Cruz (CEP/Fiocruz)

Marisa Palácios

Médica, doutora em Ciências pela Coordenação dos Programas de Pós-graduação de Engenharia da Universidade Federal do Rio de Janeiro (Coppe/UFRJ), professora adjunta do Núcleo de Estudos de Saúde Coletiva da Universidade Federal do Rio de Janeiro (Nesc/UFRJ) 
Marlene Braz (Organizadora)

Doutora em Ciências pelo Instituto Fernandes Figueira da Fundação Oswaldo Cruz (IFF/Fiocruz), médica psicanalista e pesquisadora em Bioética no IFF/Fiocruz

Miguel Kottow

Doutor em Medicina, mestre em Sociologia, professor titular da Universidade do Chile - Faculdade de Filosofia e Humanidades, Faculdade de Medicina

Rita Leal Paixão

Médica veterinária, doutora em Ciências pela Escola Nacional de Saúde Pública Sergio Arouca da Fundação Oswaldo Cruz (Ensp/ Fiocruz), professora adjunta do Instituto Biomédico da Universidade Federal Fluminense (UFF)

Sergio Rego

Médico, doutor em Ciências pelo Instituto de Medicina Social da Universidade Estadual do Rio de Janeiro (IMS/Uerj), pesquisador adjunto da Escola Nacional de Saúde Pública Sergio Arouca da Fundação Oswaldo Cruz (Ensp/Fiocruz), editor da Revista Brasileira de Educação Médica 


\section{SUMÁRIO}

Apresentação

1. A Bioética do Início da Vida 19 Miguel Kottow

2. Cuidados em Saúde da Mulher e da Criança, Proteção e Autonomia Fermin Roland Schramm

3. Deontologia e Assistência Materno-Infantil 67 José Luiz Telles \& Ana Paula Abreu Borges

4. Competência Bioética do Profissional na Assistência Materno-Infantil 81

Sergio Rego, Marisa Palácios \& Fermin Roland Schramm

5. Alocação de Recursos na Assistência Materno-Infantil ... 105 Gabriel Eduardo Schütz \& Fermin Roland Schramm

6. Bioética e Biodireito: quem defende os interesses da criança? 125 Heloisa Helena Barboza 
7. Ética em Pesquisa na Área Materno-Infantil

Marisa Palácios, Sergio Rego \& Fermin Roland Schramm

8. Bioética e Reprodução Humana ............................................ 169 Marlene Braz

9. Bioética, Testes Genéticos e a Sociedade Pós-Genômica 195 João Gonçalves Barbosa Neto \& Marlene Braz

10. Bioética e Neonatologia 219 Carlos Dimas Martins Ribeiro

11. Macacos sem Mãe, Pesquisas sem Ética: lições dos estudos de separação materno-infantil e seus desafios à Bioética 237 Rita Leal Paixão

12. Bioética e Pediatria 259 Arnaldo Pineschi de Azevedo Coutinho 


\section{Apresentacẽo}

Esta é uma coletânea de artigos escritos por profissionais que pesquisam e trabalham no campo da Bioética. Optamos por convidar pesquisadores do estado do Rio de Janeiro para tornar público o trabalho que vem sendo feito desde o começo dos anos de 1990 na Fundação Oswaldo Cruz (Fiocruz), em particular na Escola Nacional de Saúde Pública Sergio Arouca (Ensp), na qual se constituiu, posteriormente, o Núcleo de Ética Aplicada e Bioética (Nubea), que integrou também profissionais do Instituto Fernandes Figueira (IFF), onde, desde 2002, é ministrado o Curso de Especialização em Ética Aplicada e Bioética em parceria com a Ensp. Todos os integrantes do Nubea são autores de um ou mais artigos deste livro.

Alguns colaboradores atuam em outras instituições, como a Universidade Estadual do Rio de Janeiro (Uerj), a Universidade Federal Fluminense (UFF) e a Universidade Federal do Rio de Janeiro (UFRJ). Por fim, os organizadores também convidaram um colaborador constante das iniciativas bioéticas no Rio de Janeiro, o exímio bioeticista Miguel Kottow, um dos precursores da Bioética na América Latina e professor da Universidade do Chile. Todos esses especialistas, que ao longo dos anos vêm contribuindo para disseminar a Bioética em nosso estado, foram convidados a participar deste livro escrevendo sobre o tema Bioética da Saúde Materno-Infantil ou, como prefere chamar um dos autores, Bioética da Saúde da Mulher e da Criança.

Nascida no início dos anos de 1970 nos Estados Unidos, a Bioética ganhou um espaço incomensurável por designar um novo âmbito de 
pertinência em que se entrecruzam aspectos teóricos e práticos relativos às ações humanas no campo das ciências e técnicas da vida e da saúde. Portanto, sua área de atuação deve ser considerada mais vasta do que a da tradicional ética médica, pois se preocupa com ações, situações e conseqüências que podem transformar, de maneira substantiva e irreversível, a própria estrutura de qualquer ser vivo e seus contextos bioecológicos. No entanto, esta transformação, tornada possível com a tecnociência e a biotecnociência contemporâneas, vem se tornando paulatinamente objeto de preocupação não apenas de médicos e outros profissionais da saúde, mas também de especialistas das ciências humanas e sociais, como filósofos, teólogos, juristas, sociólogos, antropólogos, e, de maneira geral, da população como um todo, o que torna a Bioética uma espécie de campo-síntese das práticas teóricas e normativas, em que se confrontam e afrontam vários tipos de saber, em um autêntico trabalho pluri, multi, inter e transdisciplinar.

Em particular, os serviços de alta complexidade - como as Unidades de Tratamento Intensivo (UTI) neonatal e pediátrica, as cirurgias reparadoras e a tecnologia envolvida nos testes preditivos genéticos - tiveram um crescimento acentuado nos últimos anos e sua tendência é crescer ainda mais. A questão que se coloca, na realidade, é uma necessidade e um problema. Necessidade: atender aos pacientes com meios ordinários ou extraordinários. Problema: as questões éticas que se apresentam aos profissionais que trabalham nesses setores.

Os problemas ou conflitos éticos com os quais os profissionais da saúde se deparam cotidianamente são basicamente dois: 1) a obrigação moral de salvar a todos, indiscriminadamente e em qualquer circunstância; 2) quando se pode considerar moralmente defensável interromper um tratamento extraordinário, já que o mesmo redunda em sofrimento evitável e os benefícios advindos de seu uso são muito pequenos em relação aos danos ou seqüelas que, de fato, não permitiriam uma qualidade de vida razoável ao paciente.

Esses serviços têm, em seu quadro, profissionais especializados que precisam de um constante aprendizado em função dos sofisticados meios 
diagnósticos e terapêuticos e da própria evolução do aparato tecnológico. Mais especificamente no IFF, em função de seu perfil terciário, a UTI Neonatal está acoplada a uma maternidade de risco e conta com cirurgiões pediátricos que atendem aos bebês necessitados de cirurgia neonatal e um serviço de genética clínica e laboratorial, todos de referência no estado do Rio de Janeiro. O instituto também está voltado para pesquisa na área materno-infantil. Sua pós-graduação stricto sensu situa-se em saúde pública, na subárea de estudos sobre a criança e a mulher. A vocação transdisciplinar do programa gerou uma publicação regular, que consiste em livros-coletânea adotando números temáticos, organizados por pesquisadores da instituição.

Este livro tenta responder aos problemas de ordem ética que surgem a todo momento dentro de uma instituição voltada para um atendimento terciário onde é comum surgirem diferentes conflitos, destacando-se a conflituosidade de tipo moral, que é justamente o objeto da ética e, no caso específico, da Bioética. Assim sendo, três perguntas serviram de orientação para os autores convidados: o que fazer, como fazer e quando fazer?

O público-alvo desta publicação é composto por profissionais da saúde que trabalham na área da saúde da mulher e da criança, estudantes de graduação e pós-gradução e residentes de medicina e de enfermagem, sendo também de interesse para alunos de todos os demais cursos do campo da saúde. A especificidade apontada decorre do forte enfoque nos aspectos clínicos da prática em saúde.

Os artigos foram organizados de modo a trazer os principais problemas com os quais se deparam os profissionais em sua prática cotidiana. No primeiro, "Bioética do início da vida", Miguel Kottow trata de uma questão que perpassa vários temas caros à Bioética, como os relacionados ao início e ao fim da vida. Enfocando a questão do estatuto do embrião, este artigo relaciona o início da vida às questões do aborto, da reprodução assistida, da clonagem terapêutica e reprodutiva e dos conflitos materno-fetais.

No segundo artigo, "Cuidados em saúde da mulher e da criança, proteção e autonomia", Fermin Roland Schramm aborda o tema a partir de 
dois pontos de vista: o da saúde pública e o da Bioética laica. O autor considera que ambos podem ser vistos como sendo ao mesmo tempo distintos - mas não disjuntos - e vinculados - mas não confundidos entre si nem subsumidos um ao outro -, sendo necessário, portanto, encará-los numa relação complexa, a qual deve ser referida ao progresso tecnocientífico (e à conseqüente possibilidade de melhorar a qualidade de vida humana) $\mathrm{e}$ também à persistência da pobreza e da exclusão social. No plano especificamente epistemológico, o autor pretende desconstruir a expressão 'saúde materno-infantil' e propõe substituí-la por 'saúde da mulher e da criança'. Por fim, também aborda as questões relativas ao aborto, à reprodução assistida e à clonagem, principalmente terapêutica, enfocando o conflito entre os princípios da proteção e da autonomia.

Em "Deontologia e saúde materno-infantil", José Luiz Telles e Ana Paula Abreu Borges enfocam o âmbito conceitual e de aplicação da deontologia profissional e pretendem tornar explícitas algumas questões que envolvem o dever do profissional da saúde em face da assistência materno-infantil. Os autores discutem não só os códigos de ética das diferentes profissões em saúde como também os temas levantados por declarações internacionais em relação aos direitos das crianças particularizando o Estatuto da Criança e do Adolescente (ECA) - em função de trazerem desafios para a prática dos profissionais da saúde.

Sergio Rego, Fermin Roland Schramm e Marisa Palácios discutem de que forma é possível contribuir para o desenvolvimento da capacidade dos indivíduos de realizarem julgamentos morais autônomos no artigo "Competência bioética do profissional na assistência materno-infantil". A forma dialógica adotada - em alguns momentos até coloquial - pretende refletir ao mesmo tempo as preocupações práticas, inscritas na formação moral do profissional, e teóricas, embasadas em referenciais apropriados, mas subordinadas à finalidade consistente de responder à pergunta: "De que forma as ferramentas da teoria podem ser utilizadas como referência para a organização de sua ação educativa?".

Em "Alocação de recursos na assistência materno-infantil", quinto artigo desta coletânea, Gabriel Eduardo Schütz e Fermin Roland Schramm 
enfocam um dos problemas mais conflituosos da Bioética, destacando algumas de suas facetas que, em determinadas situações, podem se tornar autênticos dilemas morais quando o tema é discutido no âmbito da saúde da mulher e da criança. A discussão vai desde como deve ser feita a alocação de recursos, quais critérios éticos deverão ser levados em conta, até os recursos necessários para o financiamento da saúde.

No sexto artigo, "Bioética e Biodireito: quem defende os interesses da criança?", Heloisa Helena Barboza aponta, a partir dos princípios da autonomia e beneficência, as dificuldades envolvidas na observância da vontade de pacientes como crianças, adolescentes ou incapazes, que, embora possam estar em "em estado de consciência, de se autodeterminar e de expressar sua livre vontade de forma válida", ainda encontram muitos obstáculos para verem respeitadas as suas autonomias. Desse modo, questões da Bioética que dizem respeito ao poder de decisão dos médicos e dos responsáveis e aos limites desse poder são discutidas ao longo do artigo.

No sétimo artigo, "Ética em pesquisa na área materno-infantil", os autores Marisa Palácios, Sergio Rego e Fermin Roland Schramm introduzem o tema da regulamentação das pesquisas em seres humanos no Brasil, enfocando, a seguir, dois problemas relevantes: o conflito de interesses e a política de duplo padrão proposta por organizações internacionais. Em seguida, os autores apresentam algumas questões específicas do campo da saúde da mulher e da criança, julgando que tais especificidades "relacionamse com a discussão sobre a autonomia das crianças, a vulnerabilidade de crianças e adolescentes, as pesquisas em reprodução humana e na área da genética etc". Tais temas são abordados por outros autores neste livro e, dessa forma, neste artigo, optou-se pela discussão de premissas estabelecidas nas regulamentações brasileiras e em declarações sobre a proteção da criança e do adolescente.

Em "Bioética e reprodução humana", Marlene Braz discorre sobre várias problemáticas envolvidas na reprodução humana: a questão da liberdade da procriação, a infertilidade, a anticoncepção e a reprodução humana assistida. Nesse artigo, são privilegiadas tanto as normas referentes à reprodução medicamente assistida quanto a discussão em torno 
dos principais pontos que vêm sendo debatidos tanto pelos bioeticistas quanto pelos juristas sobre os seguintes itens: 1) em que circunstâncias se deve utilizar o recurso; 2) quem pode se beneficiar da técnica; 3) a gravidez de substituição; 4) quantos embriões podem ser transferidos; 5) o congelamento de embriões e o tempo de congelamento; 6) o destino dos embriões congelados; 7) o diagnóstico pré-implantatório; 8) a questão do sigilo dos doadores de gametas.

João Gonçalves Barbosa Neto e Marlene Braz, em "Bioética, testes genéticos e a sociedade pós-genômica", discutem a polêmica em torno dos testes preditivos em genética que tornam disponível o conhecimento completo dos mecanismos pelos quais mudanças genéticas podem resultar em doenças, estratégias para adiar o início da doença e prover melhores tratamentos. Consideram que a medicina preditiva, que ora está em seus primórdios, sofrerá avanços no sentido de tratamentos personalizados, ponderando uma questão ainda não resolvida: os genes de susceptibilidade, isto é, aqueles que predispõem a uma doença e que necessitam do meio ambiente para serem expressos. Os autores alertam que "um teste confirmando o risco de uma doença séria pode desencadear conseqüências psicológicas graves". Além do que, a questão dos benefícios, das limitações e das conseqüências dos testes genéticos não está pacificada. Em outro ponto discutido, os autores se detêm nos problemas de ordem éticoeconômica dos testes preditivos genéticos, abordando o princípio da proteção, desenvolvido por Schramm e Kottow, no intuito de sua aplicação na denominada sociedade pós-genômica.

No décimo artigo, "Bioética e neonatologia", Carlos Dimas Ribeiro aborda duas questões que preocupam diariamente os profissionais da saúde que trabalham nas UTIs Neonatais: a alocação de recursos em medicina intensiva e a tomada de decisão relativa às tecnologias que sustentam a vida. A partir de uma pesquisa de campo, o autor entrevistou médicos e enfermeiros que trabalham nas UTIs Neonatais, indagando sobre as seguintes questões: 1) a alocação de recursos em medicina intensiva neonatal; 2) a pertinência de se utilizar critérios de seleção de pacientes; 3) os critérios adotados para seleção de pacientes; 4) as justificativas morais 
para a limitação do esforço terapêutico; 5) a participação da família nas decisões médicas.

Rita Leal Paixão, em "Macacos sem mãe, pesquisas sem ética: lições dos estudos de separação materno-infantil e seus desafios à Bioética", traz as questões relacionadas à eticidade das pesquisas que utilizam animais. A partir de estudos relativos, principalmente ao que concerne à utilização de macacos Rhesus em pesquisas de laboratório - notadamente as que implicavam as relações mãe-bebê -, o artigo discorre sobre a ética animal e a inadequação de pesquisas que utilizam o termo errôneo de 'modelo animal'.

Em "Bioética e Pediatria", Arnaldo Pineschi enfatiza a autonomia da criança e do adolescente, contrapondo-a à beneficência do médico, como também em relação aos pais. A partir de conceitos advindos da Bioética, da legislação em vigor e das diversas declarações que visam a proteger a infância e a adolescência, o autor problematiza o princípio da autonomia, alertando, segundo suas próprias palavras, que "o avanço dos estudos e da conceituação sobre a autonomia fez com que se aumentasse também a dúvida de como conduzir situações de conflito, nas quais a análise dos limites da autonomia seja obrigatória".

Por fim, cabe agradecer aos editores da Coleção Criança, Mulher e Saúde pelo convite e pelo apoio que tornaram possível a organização deste livro.

Os Organizadores 


\section{A BioÉtica do lNíCIO dA VIDA}

\section{1}

Miguel Kottow

\section{INTRODUCÃO}

Juntamente com a morte, o início da vida é o tema que se faz mais presente no pensamento humano de todas as épocas. A curiosidade especulativa e científica tem-se interessado por discorrer sobre como se iniciou a vida em geral e quais são os mecanismos que se encontram no começo da gestação de todos os seres vivos, particularmente os da vida humana. Do mesmo modo, esse tema foi incorporado em doutrinas religiosas, as quais elaboraram conclusões autorizadoras ou condenatórias que se chocam com a cultura leiga, com os avanços da tecnologia científica e com as reflexões da Bioética. Tanto o início quanto o fim da vida humana requerem conceitos do que são a vida, a vida humana e a vida pessoal, mas, a partir do momento em que a morte converteu-se em um problema bioético - quando a medicina aprendeu a intervir ativamente no processo de morrer -, os conflitos em torno do começo da vida têm sido objeto de uma preocupação pública mais permanente.

Se o processo de gestação dos seres humanos houvesse permanecido no campo do natural, sendo modulado, mas não radicalmente modificado por artifícios instrumentais, não haveria maior preocupação ética nesse âmbito. Entretanto, os fatos não se deram dessa maneira e, ao contrário, o ser humano sempre interveio na reprodução de sua própria espécie. Já a Bíblia estabelece ditames em várias instâncias sobre essa matéria, a exemplo 
da proibição do onanismo - o coitus interruptus - e da aceitação do adultério e das relações incestuosas com fins reprodutivos (como nos casos de Abraão e Agar ou das filhas de Ló). Maimônides fazia recomendações sobre posturas copulativas que favoreceriam a concepção de filhos varões. Não deixa de ser digno de nota que uma função biológica tão natural quanto a reprodução tenha sido submetida, desde os primórdios da medicina, a preceitos, leis e políticas públicas, a começar pelo juramento hipocrático embora em sua versão cristianizada do século II -, que proscreveu o aborto provocado, e continua a sê-lo até os tempos atuais, quando surgem os dilemas éticos da fecundação assistida e da reprodução artificial.

Na Bioética, o início da vida é debatido a partir de três conceitos, todos incompatíveis entre si e cada qual profundamente convencido das visões a respeito da legitimidade de intervir artificialmente no processo de gestação.

\section{Aborto e Comeco da Vida Humana}

As atitudes perante o aborto provocado têm-se relacionado com o conceito de início da vida adotado pelas diversas culturas, razão pela qual cabe fazermos uma pequena digressão sobre o assunto. Nos primeiros séculos da doutrina eclesiástica, a interrupção voluntária da gravidez foi desigualmente condenada pela igreja católica, conforme o feto já fosse animado ou não, e, posteriormente, com base no critério de ele estar formado à imagem de um ser humano - a centenária discussão 'de animatione foetus'.

Somente a partir de 1869 é que foi decretada pelo Papa Pio IX a proibição absoluta de abortar o produto da concepção, qualquer que fosse seu estado de desenvolvimento. Com isso, gerou-se o temor de uma zona cinzenta, em que a gravidez poderia haver se iniciado, mas sem ter sido confirmada, e em que qualquer manobra para evitar a concepção seria apenas presumivelmente abortiva, por desconhecer se a fecundação havia ocorrido. Em conseqüência, estendeu-se um manto protetor sobre toda gravidez possível, proibindo-se a anticoncepção artificial, de tal sorte que toda relação sexual fosse unitiva e procriadora, 
de maneira voluntária e consciente. No caso de uma relação forçada estupro, violação ou incesto -, o dom da procriação não ficava anulado e, para as posturas dogmáticas, persistia a proibição do aborto. Com isso, pareceu evitar-se o problema de determinar o começo da vida humana, que se iniciaria, presumivelmente, no ato sexual, ficando proibida qualquer interferência no processo reprodutivo.

A rigidez dessa doutrina não resistiu ao decorrer do tempo, tendo havido uma liberalização tanto dos costumes como das leis; restam apenas escassos redutos culturais em que o aborto é ilegal e penalizado (como a América Latina), em alguns casos sem que se aceite qualquer exceção como no Chile. A descriminalização do aborto provocado tem adotado formas muito variadas para determinar os prazos dentro dos quais a gravidez pode ser interrompida, os quais costumam estar pautados de acordo com os riscos trazidos por intervenções abortivas tardias, sem considerações sobre a idade ou o grau de desenvolvimento do feto. A viabilidade tampouco é um critério confiável, uma vez que as técnicas de incubação artificial conseguem completar o desenvolvimento de fetos muito imaturos - com menos de 500 gramas -, nos quais, todavia, há uma alta incidência de patologias graves e irreversíveis, o que é aceitável em uma gravidez desejada, mas não quando o objetivo é abortar voluntariamente, deixando num limbo conceitual o termo 'viabilidade'.

Os antecedentes históricos, sucintamente apresentados, mostram como a determinação do começo da vida, na atualidade, tem apenas uma importância reduzida para regular as condutas de rejeição da gravidez indesejada: ou ela é terminantemente proibida, seja qual for o estágio de desenvolvimento do produto da concepção, incluindo a suspeita de fecundação, ou é permitida, dentro de limites estabelecidos por razões alheias à formação alcançada pelo embrião/feto.

Não obstante, o início da vida continua a ser um dos temas mais controvertidos da Bioética. A razão disso é que os processos de fecundação e reprodução artificializaram-se a tal ponto que é possível iniciar a vida humana em laboratório, modificar sua composição genética, selecionar o produto obtido e dar início a seu desenvolvimento, para depois entregar 
sua evolução e maturação a um útero humano, geneticamente relacionado ou não com o embrião. Todas essas manobras significam uma reprodução sexuada, mas não sexual; uma composição genética dirigida e até programada, porém não mais aleatória; o desenvolvimento de embriões escolhidos segundo critérios de saúde genética, bem como por motivos idiossincráticos - do tipo da ausência de enfermidades ligadas ao sexo -; e a criação de um vínculo artificial e supostamente provisório entre o embrião e o útero acolhedor, que pode não ser o útero da mãe genética nem da eventual mãe social.

Diante de tamanhos artifícios, só pode desencadear-se um intenso debate bioético, que tenta determinar o status moral dos diversos participantes e a conduta ética que cabe adotar em relação a eles. Com isso se explica por que o problema inicial e fundamental é determinar o começo da vida humana e o status moral que ela tem, uma vez que existe um consenso amplo, embora não absoluto, de que toda vida humana, uma vez reconhecida, é, indiscriminadamente, um sujeito moral a quem são conferidos os mesmos direitos fundamentais de preservação, proteção e apoio. A pergunta crucial é em que momento se reconhece o aparecimento da existência humana e quais são os critérios que deverão validar esse reconhecimento.

\section{Conceitos do lníclo da Vida Humana}

O aspecto concretamente controvertido não é em que momento se inicia o processo vital, pois não é difícil admitir que este ocorre, nas formas de reprodução sexuada, no momento da união dos gametas, cuja consolidação ocorre com a implantação ou nidação uterina. Entretanto, essas considerações biológicas, mas não especificamente humanas, afirmam a presença de um processo que é diagnosticado com base no cumprimento de etapas do desenvolvimento embrionário. A questão de fundo é determinar se os processos do início da vida são paralelos e idênticos ao aparecimento da vida humana, inclusive, para alguns, da vida pessoal. 


\section{A VISÃO CONCEPCIONAL}

A perspectiva mais radical e intransigente insiste que a vida humana pessoal se inicia ao se produzir a união do óvulo com o espermatozóide, em um processo de fusão de membranas denominado singamia. A partir dessa união, começam a recombinação genética e a evolução de um novo ser humano, que, por ter uma dotação genética completa e definitiva, é uma pessoa humana. Os traços ainda não-detectáveis são tidos como potencialmente presentes e a eles se atribui o mesmo status moral que receberão quando vierem a se materializar.

Tal postura apresenta um feixe de incertezas que precisam ser analisadas: os conceitos de pessoa, potencialidade, gravidez suposta e etapas anteriores à singamia.

$O$ atributo da potencialidade deve ser entendido em um sentido mais específico do que uma mera possibilidade vislumbrada ou suspeitada. Toda criança de seis a sete anos de idade que tenha aprendido a ler e escrever é, potencialmente, o(a) futuro(a) presidente de seu país, mas as probabilidades de que isso ocorra são tão ínfimas, fazendo com que o termo 'potencialidade' passe a carecer de qualquer força argumentativa.

A teoria hilemórfica de Aristóteles - a realidade constitui-se de matéria e forma - servia-se da idéia de que a matéria é potencialmente realizável mediante a forma. Essa interação é produzida por um princípio dinâmico: a dýnamis, como predisposição ou capacidade, é a potência que age sobre a energeia, a força realizadora ou o ato de produção do ser. A dinâmica desses processos obedece a um programa, tem por causa um ser realizador e, como todo ser, tende para um fim ou uma meta, que é a autorealização. O ser trabalha em sua própria realização como ser humano, e o cumprimento dessa meta conduz à eudemonía - ou felicidade. A visão aristotélica cria uma união causal férrea, mas também uma união temporal entre potencialidade e realização.

No pensamento contemporâneo de Alfred North Whitehead, transparece a preocupação com as probabilidades que dão solvência ao conceito de potencialidade. Ele admite que, em tese, metafisicamente, as 
potencialidades constituem um conjunto infinito de mudanças concebíveis nos objetos eternos. Esse é o mundo das idéias platônicas, a partir do qual há múltiplas possibilidades de dar-se origem a realidades fenomênicas. Esse mundo de realidades perceptíveis já tem um leque delimitado de transformações possíveis, sendo todas essas potencialidades detectáveis.

Como primeira conclusão, deduz-se que a idéia de um novo ser humano certamente pode abarcar todas as potencialidades que já se tenham realizado em algum momento na humanidade, mas, quando se está, aqui e agora, diante de uma gravidez que abriga um embrião ao qual se atribui a potencialidade de vir a ser uma pessoa desenvolvida, a faixa de potencialidades previsíveis se restringe e depende de fatores adicionais que, nesse momento, ainda não são conhecidos: nutrição, vida familiar, socialização e projetos.

Conceder ao embrião um status moral equivalente ao da pessoa, com base numa potencialidade hipotética, não-detectável e sujeita a inúmeras contingências, situa o argumento no plano metafísico de Whitehead, que corresponde à realidade platônica das idéias e só diz respeito aos que compartilham essas crenças, sem conseguir estabelecer-se como uma afirmação que possa ter um caráter normativo universal.

A perspectiva proposta, baseada em um frágil e incerto futuro pessoal, apresenta um segundo ponto fraco ao tentar correlacionar o status moral com a personalidade. Afirmar que existe uma pessoa desde a etapa do zigoto desvirtua o conceito, pois, desde Boécio até a Bioética contemporânea, aceita-se que as pessoas constituem um subgrupo dos seres humanos nem todo membro da espécie Homo sapiens sapiens é, foi ou será uma pessoa.

Todas as definições de pessoa contêm como atributo essencial a racionalidade, sendo paradigmática a asseveração kantiana que assinala que pessoa é todo agente racional e moral. Se a pessoa se caracteriza antropologicamente por ser racional, a ética acrescenta que as pessoas são agentes morais que agem com liberdade e responsabilidade. Portanto, existem seres humanos que ainda não são pessoas (os recém-nascidos), que nunca o serão (os deficientes mentais) ou que deixaram de sê-lo (os que estão em estados vegetativos persistentes ou na demência senil). 
Quando se equipara a pessoa com o status moral, como têm feito insistentemente alguns autores - Peter Singer, Tom. L. Beauchamp, Robert Veatch, John Harris -, cria-se uma discriminação moral em relação a seres que não são pessoas, embora sejam humanos. Para evitar essa conseqüência inaceitável, é preciso reprisar que todos os seres humanos são sujeitos morais que devem ser tratados com o respeito e os cuidados que lhes são devidos como seres humanos, mas que somente as pessoas são, além de sujeitos, agentes morais chamados a responder pelos atos que decidem livremente praticar.

Por conseguinte, o status moral não depende de alguém ser uma pessoa, mas de ser um indivíduo humano, e esse status começa a vigorar no momento do início da vida como humana. Para a visão concepcional, esse momento pode existir, apenas como hipótese, como conseqüência de todo ato sexual, daí resultando o paradoxo de que só há testemunho desse início na fecundação in vitro, mas não em um evento natural - ou seja, a rigor, a lei natural só é aplicável na situação artificial. Dificilmente se poderá exigir um status moral para seres cuja existência não é detectável.

Algumas tentativas de dar um caráter ainda mais seguro e universal à determinação do início da vida acabaram por desestabilizar o critério concepcional. Não é a singamia que marca esse início, afirma-se, porque existem formações zigóticas em que não há fusão de membranas gaméticas, ou essa fusão é artificialmente evitada no método de injeção intracitoplasmática de espermatozóide (ICSI). O que marcaria o começo do processo de individuação vital seria a ativação do ovócito desencadeada pela presença do espermatozóide, mas também nesse caso alguns elementos dessa ativação são rechaçados por serem inespecíficos ou ausentes em algumas espécies.

A conclusão é que a vida individual do novo ser começa quando o citoplasma oocítico "faz ativamente a endocitose do núcleo do espermatozóide e começa a ativá-lo, ou começa a ativar o núcleo (ou material hereditário) que lhe foi injetado" (Valenzuela, 2001: 445). O início da vida em geral e do ser humano, em particular, converte-se em um processo oculto, que só pode estabelecer o começo de um status moral com base em 
suposições e extrapolações. No mais, essa busca de momentos determinantes em um processo contínuo começa a assemelhar-se, conceitualmente, ao critério evolutivo do começo da vida.

\section{A VISÃO EVOLUTIVA}

A aceitação mais geral tem sido a idéia de que a vida humana se inicia em algum momento do processo de desenvolvimento e maturação. A fase evolutiva em que se dá por iniciada a vida humana vem sendo estabelecida de maneiras muito diversificadas. Um critério recente, mas amplamente reconhecido, é o $14^{\circ}$ dia de gestação, no qual o embrião se implanta e se afirma com boas probabilidades de viabilidade. Mas a implantação mais parece um critério de gravidez exitosa do que de desenvolvimento ontogenético, razão pela qual existem diversas opiniões que situam o começo da vida humana em etapas posteriores. Classicamente, o critério tem sido a animação, mas este é tão impreciso, que a Congregação Para a Doutrina da Fé acabou por ratificar a afirmação de Pio XII na Encíclica Humani Generis: "a alma espiritual de cada homem é 'imediatamente criada' por Deus" (1994: 11). Sendo assim, essa variante do critério evolutivo superpõe-se à visão concepcional e restringe sua validade àqueles que confiam na visão metafísica que a fundamenta.

Outro critério de começo da vida que tem antecedentes históricos importantes é a viabilidade fetal, mas, quanto a esta, o desenvolvimento da medicina tem gerado uma situação paradoxal: quanto mais imaturo é o feto, mais precário é seu futuro para desenvolver plenamente os atributos de um ser humano com capacidade de tornar-se uma pessoa.

Outros momentos do desenvolvimento têm sido tomados como determinantes para o reconhecimento do início da vida humana, como o aparecimento da crista neural, a deteç̧ão de movimentos fetais ou o nascimento a termo - ao se completar a gestação natural. Mas todos são momentos arbitrariamente escolhidos e não gozam de reconhecimento generalizado, havendo-se chegado a situações extremas em que só é reconhecido o começo da vida humana depois de manifestar-se a 
racionalidade. Quando se faz o status moral depender do desenvolvimento da capacidade racional, cai-se no absurdo de autorizar o infanticídio de crianças pré-racionais, às quais se negaria o tratamento moral devido aos seres humanos.

\section{A VISÃO SOCIAL}

Pela perspectiva do construtivismo social, não existem essências nem atributos humanos naturalmente dados, mas todos evoluem de acordo com os símbolos culturais elaborados no seio da sociedade. A maneira como o ser humano e a pessoa são determinados e vão adquirindo participação no discurso moral é produto do meio social (Greene, 2001). A chamada escola das conseqüências sociais considera a pessoa como um constructo social, cujos antecedentes genéticos servem de matriz dispositiva. Com base neste ponto de vista e em total contraposição à postura essencialista ou concepcional, as células-tronco não têm status moral próprio, porque seu significado moral é o de células totipotentes, mas não de indivíduos humanos.

\section{A VISÃO RELACIONAL}

Embora seja a menos elaborada das concepções sobre o início da vida humana, essa visão tem maior vigência social no significado que os indivíduos atribuem ao começo de uma vida nova e nas decisões que eles tomam a partir dessa postura do senso comum.

As decisões tomadas na área biomédica e os desafios apresentados à Bioética funcionam, de fato e explicitamente, com base no critério relacional do início da vida humana. Para a perspectiva relacional, o reconhecimento de um novo ser enraíza-se menos nas características ontológicas que ele possua do que no estabelecimento de uma relação com ele. O apoio acadêmico a essa postura ainda é escasso, por mais generalizadamente que a sociologia o detecte. Segundo Grobstein (1981: 102), "a questão é determinar quando o desenvolvimento do embrião ou feto é geralmente reconhecido como humano e evoca empatia em outro ser". 
Maturana (1991: 143) opina, categoricamente, que:

a humanização do embrião ou feto não é um fenômeno que tenha lugar como parte de seu desenvolvimento, mas principia quando a gravidez começa a ser um estado desejado pela mãe e esta se desdobra em seu sentir e sua reflexão, dando origem, em seu ventre, a um ser que tem um nome e um futuro.

Quando sabe estar grávida, a mulher, de acordo com a maioria das legislações contemporâneas, encontra-se em condições de exercer um direito de escolha: assumir a maternidade ou rejeitar a gravidez, buscando o aborto. Quando a gravidez é indesejada ou forçada, a escolha do aborto conta com vasto apoio moral e jurídico, embora este não seja incontestavelmente unânime. Do ponto de vista ético, parece mais válido que a maternidade seja um ato de escolha do que uma imposição natural. O reconhecimento do início de uma vida humana por aceitação e compromisso, como propõe a visão relacional, é uma atitude moralmente louvável e superior à acolhida passiva da gravidez como um fato consumado e irreversível.

Para pensadores como Emmanuel Levinas, a ética nasce no momento do encontro com o outro e de sua aceitação. A ontologia - a consciência de ser entre seres - é precedida pela relação com o outro e pela assunção da responsabilidade por ele. A diaconia, diz Levinas, precede o diálogo. Toda a ética filosófica, pelo menos desde Max Weber, gira em torno do agir de maneira responsável perante os demais, de modo que é coerente propor que a relação mãe/filho se inicie no momento em que a mãe conhece e aceita a presença do outro em seu ventre. Negar esse direito a uma mulher que não esteja disposta a ser mãe constitui, na visão relacional, uma grave falha ética, tanto em função do desprezo por sua autonomia quanto em função das graves conseqüências que pode ter uma gravidez indesejada, ou, mais ainda, produto de um estupro ou uma violação.

Desenvolveu-se toda uma complexa estratégia diagnóstica para detectar a gravidez e também para pesquisar precocemente a presença de malformações severas no embrião. O objetivo não pode ser apenas antecipar o que se confirmará depois, mas sim fornecer à mulher, o mais cedo possível, os elementos necessários para que ela aceite ou descarte a gravidez, isto é, 
antecipar a alternativa de ela gerar ou não uma relação com o possível novo ser, cuja viabilidade dependerá da escolha e que será um ser humano, ou não poderá sê-lo, conforme a disposição da mulher. A assunção da relação mãe/filho, ao dar início à existência de um ser humano, é irreversível, pois, se a mulher resolver dar continuidade à gravidez e mais tarde se arrepender, terá dado vida a um ser humano para depois negá-la, em um ato que, então sim, será de caráter homicida.

\section{Matizes}

Decerto existem modulações nas doutrinas inflexíveis. Com base no pensamento hilemórfico de Aristóteles, procura-se considerar o zigoto como uma matéria que ainda não possui estrutura, e o embrião primitivo, como adquirindo a forma humana que constituirá a base de sua individualidade ao longo de sua vida (Copland \& Gillett, 2003). Para o mundo pragmático, é difícil esse renascimento do hilemorfismo, que não tem tradução em conceitos contemporâneos que possam inspirar prescrições e decisões.

O reconhecimento do início da existência de um ser humano tem uma dimensão temporal e uma dimensão ontológica. Fala-se da ontogênese como um conceito que inclui o ôntico - o ser em si - e a gênese ou devir desse ser. As diversas formas de encarar a formação do ser exibem, todas elas, uma deficiência de um desses aspectos. A visão concepcional ou essencialista simplesmente reconhece o aparecimento do ser desde o momento da concepção, sem levar suficientemente em conta que esse ser se modificará tão radicalmente, ao longo do tempo, que se torna difícil ver o zigoto como essencialmente isomorfo em uma pessoa adulta, como se todos os processos de desenvolvimento, maturação, diversificação e transformação não tivessem importância para determinar o ser.

A concepção evolucionista é cega para o substrato ôntico e vê apenas processos de mudança, sem considerar que o que se modifica é uma realidade ôntica. A valorização do processo comemora as etapas que configuram o ser, mas se esquece de ponderar que tipo de ser existia antes dessas etapas.

A perspectiva social leva essa miopia ôntica à sua expressão máxima, pois tudo o que a pessoa vem a ser é produto de influências externas. 
Ela menospreza o fato de que as circunstâncias se realizam sobre um ser que não é mera disposição e cujas características se modificarão, mas não serão criadas, desde o início, pela modulação social.

O modo relacional de entender o começo da vida não opina sobre a ontogênese, porque o momento do reconhecimento do novo ser não depende de suas características ônticas nem do momento evolutivo. A mulher que toma a decisão de favorecer a vida gera o novo ser através do estabelecimento da relação mãe/filho, sem se preocupar em saber se existe uma crista neural ou se o embrião atingiu ou não uma capacidade senciente. Nesse sentido, seu compromisso é eticamente puro e incondicional, não determinado pelo biológico, tal como o são os atos morais que se praticam sem que se pergunte pelas características do outro.

A reprodução humana é um campo paradigmático para o desenvolvimento da Bioética como ética aplicada, referida, por um lado, ao expressivo desenvolvimento teórico das proposições em torno do começo da vida humana, e enfrentando, no outro extremo, práticas de fecundação assistida e cultivo de células primígenas, mediante técnicas imensamente complexas e variadas que buscam uma fundamentação ética para continuar investigando e se desenvolvendo por caminhos que a imaginação humana ainda não consegue captar por completo.

\section{Fecundação Artificialmente lnduzida}

A fertilização tecnicamente assistida, sobretudo em sua forma de fecundação in vitro, é a mais clara demonstração da vigência de um enfoque relacional para determinar o começo da vida humana. Essa é a nova situação biomédica que exige repensar os conceitos e as significações relacionados ao princípio da vida humana. A fecundação in vitro inicia uma série de processos celulares que implicam a fusão genética, desencadeando uma multiplicação celular ainda indiferenciada. Esses conjuntos celulares terão um destino diverso: alguns perderão sua viabilidade, outros migrarão para câmaras frigoríficas das quais pouquíssimos serão novamente retirados, e outros serão implantados num útero humano, com maior ou menor probabilidade de desenvolverem-se, tendo uma alta probabilidade de 
fracassar ou de serem ativamente eliminados por intervenções de seleção e redução embrionária. Todos esses projetos embrionários, dada a sua enorme percentagem de inviabilidade e destruição, são mais propriamente considerados como material biológico, exceto nos poucos casos em que se consegue uma gravidez bem-sucedida. Como a fecundação artificial é voluntariamente solicitada, seu sucesso cria, indefectivelmente, um vínculo relacional poderoso, o qual, também nesse caso, dá início à vida de um novo ser humano.

A fecundação assistida, no sentido de apoiar medicamente as etapas iniciais da concepção, da migração do zigoto e de sua implantação, não tem merecido nenhum reparo ético. Quando a indicação requer que se faça a fecundação in vitro, começam os primeiros protestos pelo excesso de artificialidade, vista como uma interferência desmedida em processos naturais. Quando se examina essa argumentação naturalista, constata-se que ela não tem uma opinião sobre o começo da vida; trata-se de críticas formais a certas etapas, como ocorreu com a proibição de obter-se sêmen através da masturbação. A tolerância a conceitos sobre o início da vida, mediante instrumentações sofisticadas de reprodução artificialmente induzida, vê-se raramente exigida em função das estratégias utilizadas hoje em dia, que preparam uma quantidade de embriões para uma implantação múltipla, com o objetivo de assegurar o sucesso do procedimento.

A crítica tem-se concentrado menos na fecundação e na implantação do que no fato, para ela inaceitável, de se produzirem embriões em excesso, que acabarão num congelamento eterno, no descarte ou no fornecimento de material biológico para fins de investigação, destinos estes que são todos inaceitáveis para quem valoriza esses embriões incipientes como seres humanos com um status moral irrestrito. Para os demais, trata-se de seres catalogados como pré-embriões, que não podem ser moralmente tomados como homólogos dos seres humanos nem possuem os mesmos direitos. Curiosamente, o aparecimento da técnica ICSI, que evita a produção de embriões supranumerários, tem sido aceito, embora apresente um alto grau de artificialismo instrumental, que, em outros momentos, seria motivo de rechaço. 
A tensão máxima a que se vê submetida a ponderação sobre o começo da vida apresenta-se numa situação criada pela biomedicina contemporânea: a de conseguir a fecundação in vitro e implantar o zigoto num útero emprestado ou alugado. A gestante sucedânea que, por compromisso ou contrato, carregará o feto, numa relação artificial e transitória, será mãe provisoriamente. Essa situação ilustra as turbulências e contradições da aceitação de um critério fixo do início da vida. Que é que se implanta no útero vicário: um projeto de reprodução ou um ser humano? Que status relacional tem o zigoto no útero emprestado: o de um estranho ou o de um filho temporário? Se ele for um ser humano no momento de ser implantado, não poderá ser considerado abrigado numa incubadora humana, porque, durante a gravidez, a mulher gestante adota funções insubstituíveis de mãe, sem sê-lo. Essa mulher, necessariamente, criará um vínculo com o ser a quem protege e nutre, vínculo este que reconhecerá a presença de um ser humano que é relacionalmente seu filho, mas que deverá ser rompido depois do nascimento.

A utilização do útero vicário foi proscrita e considerada nula de direito. Se o direito de ser mãe é tão legítimo para a mãe genética quanto para a mãe gestante e para a mãe social que desencadeou o processo reprodutivo, isso significa que a vida não começa com a concepção, já que três pessoas podem legitimamente reivindicar a maternidade. Não é a biologia, mas o estabelecimento de vínculos, que determina a presença de um novo indivíduo.

\section{A lnvestigação com Células-Tronco e sua UTILIZAÇ̃̃o}

O outro grande cenário em que se desenrola a polêmica em torno dos primórdios da vida humana provém da obtenção e investigação de células-tronco e de sua eventual capacidade de produzir clones terapêuticos e reprodutivos (Robertson, 1999).

Obtidas de tecidos adultos, as células-tronco não são moralmente discutíveis, pois não constituem células totipotentes com dotação genética 
suficiente para formar um novo ser humano, sendo apenas variadamente pluripotentes. Em contrapartida, as células embrionárias, a partir das quais o laboratório impregna um óvulo e configura uma célula capaz de gerar um novo indivíduo da espécie, são consideradas pelos adeptos da visão concepcional como seres humanos moralmente válidos. Por conseguinte, eles proíbem o uso e a investigação dessas células para fins terapêuticos.

Essa hesitação pode ser compartilhada por aqueles que se preocupam com a eventual clonagem reprodutiva e afirmam que as técnicas das células embrionárias, aceitáveis em si, não se restringirão a indicações terapêuticas - a propensão para a ladeira escorregadia que se observa no imperativo tecnológico (Jonas, 1985) trará o risco de que isso se estenda à clonagem de seres vivos que poderão vir a ser humanos. Nisso coincidem duas posturas de origem muito diferente: a dos deontologistas, que repudiam o uso de seres humanos para fins que lhes sejam estranhos, e a dos conseqüencialistas, que aprovariam essa técnica, desde que os fins fossem aceitáveis.

O dilema atual concernente às células embrionárias resume-se no reconhecimento de que as células-tronco adultas não têm um status moral especial, sendo legítimo e isento de riscos o seu uso na investigação e na aplicação terapêutica, porque elas são pluripotentes, mas não totipotentes. A totipotência, que abre importantes vias terapêuticas, inclusive a substituição de órgãos e a possibilidade de se vir a prescindir de transplantes, depende do fato de que essas células sejam embrionárias, isto é, de seres humanos, segundo a postura concepcional. Quão absoluta é essa postura, a ponto de se dispor a repudiar a clonagem de tecidos e órgãos, sob a alegação de que isso só é conseguido mediante o sacrifício de um ser humano em prol de sua utilidade terapêutica? O dilema está em que "a investigação feita com embriões ofenderá profundamente algumas pessoas [que aceitam a humanidade plena do embrião], mas os benefícios médicos potenciais para a geração atual e as futuras gerações ultrapassam a dor sofrida pelos que se opõem a tal investigação" (National Bioethics Advisory Commission, 1999: 51).

Os opositores ofendidos não cedem diante desse argumento, assinalando que uma estratégia utilitarista não pode violentar certos 
deveres básicos. O dever de preservar a vida do embrião é irrenunciável, ou, para sermos mais exatos e fiéis a essa postura, ela afirma que não se fornecem razões suficientemente sólidas para que se sacrifique o embrião. As doenças incapacitantes, como o mal de Parkinson, não dariam motivo para o eventual uso terapêutico de células embrionárias, sendo preferível continuar as investigações tradicionais em busca de uma cura (Doerflinger, 1999; Meilaender, 2001).

Do ponto de vista médico, é difícil aceitar essa negativa absoluta, mas também em termos conceituais cabe indagar por que não se recorre, por exemplo, ao argumento do duplo efeito, que é frágil, mas cômodo para as posturas absolutas e, segundo o qual, a instrumentalização da célula embrionária poderia ser aceita como um efeito secundário, indesejado e não-intencional, porém aceitável em função da intenção terapêutica.

As políticas e legislações referentes às células embrionárias denunciam a debilidade dos argumentos absolutistas contra seu uso. O National Bioethics Advisory Commission aceita a utilização dos embriões supranumerários descartados nos procedimentos de fecundação, mas rejeita sua criação com fins investigativos. Os dispositivos legais de outros países proíbem a preparação de células embrionárias, mas aceitam sua obtenção, importação e utilização, se elas provierem de outras nações. O valor moral das células embrionárias, portanto, depende menos de seu status ontológico do que de sua origem, o que demonstra que o embrião não tem a categoria de pessoa como um fim em si, mas que as circunstâncias permitem usá-lo como meio para atingir certos objetivos, os quais, sendo louváveis, dão primazia ao argumento utilitarista em relação ao deontológico.

Fechando o circuito iniciado com a discussão sobre o aborto, apresenta-se um outro argumento que leva as circunstâncias a primarem sobre o supostamente essencial. O aborto, espontâneo ou provocado, é uma fonte importante de células embrionárias - células germinativas primígenas -, o que é aceito por um número significativo de concepcionalistas, desde que fique demonstrado que não teve por objetivo principal ou por meta secundária a coleta de células. Mais uma vez, o status moral das células provenientes do feto abortado ou inviável só dá 
direito a valorizá-las como seres humanos se seu destino posterior não tiver sido planejado nem previsto.

\section{Dilemas Éticos em Obstetrícia}

Na ética obstétrica, discute-se se a mulher grávida é a única detentora de direitos, se o entendimento é o de duas pessoas com interesses que devem ser considerados de maneira eqüitativa, ou, como terceira alternativa, se haveria uma díade materno-infantil com interesses comuns. Feita exceção do primeiro modelo, os outros dois entendem que as necessidades terapêuticas do feto só podem ser respeitadas com a aprovação da mãe, principalmente se ela sofrer prejuízos em decorrência da intervenção. O poderio materno chega a tal ponto que a justiça norte-americana confirmou o direito de a mãe mentalmente competente recusar uma cesariana na gravidez a termo, mesmo que sua negativa signifique a morte do bebê (Spike, 1999).

Essa é a visão secular e liberal de uma antiga postura religiosa, muito claramente formulada na ética médica judaica, que outorga apenas um status moral parcial ao feto - pessoa potencial (ou sofek nefesh) - e o considera sacrificável, se ele estiver prejudicando a mãe - pessoa (ou nefesh). É o aborto justificado pela idéia de um feto perseguidor ou agressor (rodef).

Entretanto, mesmo essa assimetria entre o status moral da mulher e o do feto pressupõe que a gravidez tenha sido voluntariamente aceita:

A decisão voluntária [de assumir riscos razoáveis, para melhorar as probabilidades de ter um filho sadio] está implícita em sua decisão de não abortar e na opção pela gravidez, o que aumenta a responsabilidade assumida pela mulher em favor do feto, respaldando o dever médico de proporcionar terapia fetal. (Mattingly, 1992: 14)

E, "se uma mulher decidir não abortar, mas levar a gravidez a termo, haverá uma criança que poderá ser prejudicada pelo que a mulher fizer durante a gestação" (Steinbock, 1992: 19). A aceitação da gravidez determina a existência de um novo ser, diante do qual começam a 
responsabilidade ética e as obrigações morais de proteção materna e cuidados médicos.

Vez por outra, a bibliografia da Bioética expõe casos de gestantes que sofrem morte cerebral, dando início à polêmica em torno de ser obrigatório ou legítimo mantê-las vivas, mediante cuidados intensivos que permitam a continuação da gravidez até a viabilidade do feto. Os argumentos variam, indo desde o repúdio da utilização de um corpo declarado morto como incubadora até a aceitação desse procedimento, quando os desejos da mãe são conhecidos ou quando há familiares com interesses e desejos legítimos de dar continuidade à gravidez. É ilustrativo desse caso que a decisão dependa das pessoas envolvidas e não considere se haveria um direito do feto, como pessoa, a ser salvo a qualquer preço e sem prejuízo para a mulher cerebralmente morta, mas competente em termos de gestação. Essa é uma situação extrema e rara, mas ilustra com clareza que a trama relacional é mais determinante do que o suposto direito de nascer do feto (Cantor \& Hoskins, 1993).

\section{CONCLUSÕES}

A polêmica sobre as células embrionárias é representativa dos dois extremos cronológicos da modernidade em que vivemos. Em seus primórdios, o pensamento moderno teve de demonstrar que as perspectivas desenvolvidas pelos seres humanos não podem ser refutadas mediante argumentos absolutos, inevitavelmente baseados na fé ou na opinião. Com isso, eliminaram-se as máximas e os princípios apodícticos, pois o irracional não poderia primar sobre a razão e reivindicar universalidade, ao passo que a razão sempre deveria manter a flexibilidade da contra-argumentação. No outro extremo da modernidade, a que é contemporaneamente vivida como modernidade avançada ou pós-modernidade, abandona-se qualquer tentativa de imposição ou invasão transcultural, aceitando-se a existência de diversos modos de pensar e atribuir valores, desde que eles sejam coerentes e razoáveis e não propiciem políticas lesivas. Isso significa que o pluralismo depende da tolerância e deve, por sua vez, ser tolerante. 
Aplicada ao tema dos primórdios da vida, essa postura exige que todas as doutrinas apresentadas se aceitem mutuamente e que nenhuma pretenda impor suas convicções - pelas vias legislativa, moral ou fáctica a pessoas que pensem de outra maneira. Esse imperativo de tolerância adquire uma importância especial quando se discute a respeito de opções que podem ser benéficas para muitos, como o uso terapêutico de célulastronco. Em palavras claras, isso significa que as legislações que impõem restrições baseadas na idéia concepcional do início da vida, procurando dar-lhes validade universal, estão faltando para com a ética da tolerância e para com o princípio da não-maleficência, situando-se à margem da realidade social e, em contraposição, às práticas médicas vigentes.

\section{ReFERÊNCIAS BIBLIOGRÁFICAS}

CANTOR, J. E. \& HOSKINS, I. A. Brain death in pregnant women. The Journal of Clinical Ethics, 4: 308-314, 1993.

COPLAND, P. \& GILLETT, G. The bioethical structure of a human being. Journal of Applied Philosophy, 20: 123-131, 2003.

DOERFLINGER, R. M. The ethics of funding embryonic stem cell research: a catholic viewpoint. Kennedy Institute of Ethics Journal, 9: 151-158, 1999.

ENCÍCLICA HUMANI GENERIS. Congregación para la Doctrina de la Fe: instrucción sobre el respeto de la vida humana naciente y la dignidad de la procreación. Santiago: San Pablo, 1994.

GREENE, R. M. Does it means to use someone as 'a means only'? Rereading Kant. Kennedy Institute of Ethics Journal, 11: 247-262, 2001.

GROBSTEIN, C. From Chance to Purpose. Reading, Mass.: Addison-Wesley Publishing, 1981.

JONAS, H. Technik, Medizin und Ethik. Frankfurt am Mein: Insel Verlag, 1985.

MATTINGLY, S. S. The maternal-fetal dyad: exploring the two-patient obstetric model. Hastings Center Report, 22: 13-18, 1992. 
MATURANA, H. R. El Sentido de lo Humano. Santiago: Hachette, 1991.

MEILAENDER, G. The point of a ban: or, how to think about stem cell research. Hastings Center Report, 31: 9-16, 2001.

NATIONAL BIOETHICS ADVISORY COMMISSION. Ethical Issues in Human Stem Cell Research. Rockville, Maryland: National Bioethics Advisory Commission, 1999. (v.I: report and recommendations of the National Bioethics Advisory Commission)

ROBERTSON, J. A. Ethics and policy in embryonic stem cell research. Kennedy Institute of Ethics Journal, 9: 109-136, 1999.

SPIKE, J. Brain death, pregnancy, and posthumous motherhood. The Journal of Clinical Ethics, 10: 56-65, 1999.

STEINBOCK, B. The relevance of illegality. Hastings Center Report, 22: 1922,1992 .

VALENZUELA, C. Y. Comienzo ontogénico del individuo humano desde su genoma. Revista Médica de Chile 2001, 129(4): 441-446, 2001. 


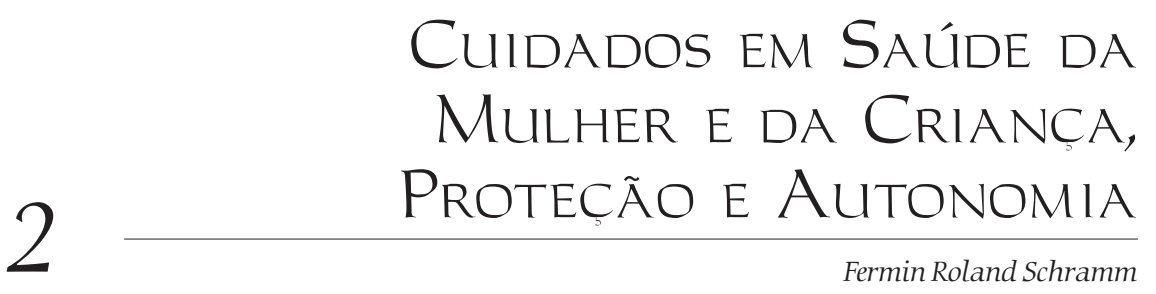

\section{INTRODUCÃO}

O sistema de práticas humanas que dizem respeito ao âmbito dos cuidados em saúde da mulher e da criança é, provavelmente, um dos mais complexos do campo da saúde pública e um dos mais controvertidos da Bioética, em particular da Bioética do começo da vida (Kottow, 2001). É complexo pelo fato de ser constituído por uma série de atividades que precisam de uma multiplicidade de competências, ao mesmo tempo especializadas e vinculadas entre si, necessitando, portanto, estar integradas num 'saber-fazer' capaz de dar conta dos vários desafios que se apresentam aos profissionais em suas práticas de 'cuidar'. Ademais, o sistema é fortemente afetado por emoções, crenças, interesses e valores, muitas vezes conflitantes entre si e que podem, em alguns casos, produzir verdadeiros dilemas morais, como quando se deve escolher entre salvar a vida da gestante ou a do feto em estado avançado de desenvolvimento ou no momento do parto.

Este é também o caso do aborto que, por um lado, mobiliza os militantes 'pró-vida' (pro-lifers) e 'pró-escolha' (pro-choicers) em autênticas guerras e que, por outro lado, é considerado por alguns autores como um autêntico paradigma do conflito de interesses entre mãe e feto (Roden, 1987). Já outros autores julgam ser à primeira vista legítimo, argumentando que não existiria um conflito de interesses de fato, pelo 
simples motivo de um feto não poder ter interesses por ser desprovido da competência de sentir e querer (Feinberg, 1974; Steinbock, 1992).

Conflitos e dilemas também podem surgir na reprodução assistida, sobretudo nos casos das assim chamadas Novas Tecnologias de Reprodução Assistida (NTRA), as quais, por um lado, podem incrementar "a autonomia individual em matéria reprodutiva [e a] eticidade de uma sociedade, (...) contribuindo, por convergência, para algum tipo de mudança na postura ética global" (Segre \& Schramm, 2001: 47) e, por outro, podem também estimular o desejo de "um forte controle público e social da reprodução [limitando significativamente] a própria liberdade de procriação" (Mori, 2001: 57). Um exemplo disso é a recente polêmica da clonagem reprodutiva - tão propagandeada, porém não confirmada -, a qual é praticamente condenada universalmente, mas que pode ser também considerada legítima quando concebida como um caso particular de clonagem terapêutica, geralmente mais aceita (Schramm, 2003a).

Na primeira parte deste texto, será definido o olhar a partir do qual será abordado o âmbito das práticas de cuidados em saúde da mulher e da criança. Trata-se de um olhar duplo: implica tanto o ponto de vista da saúde pública como o da bioética laica. Defende-se, em particular, a pertinência e a legitimidade deste duplo ponto de vista, mostrando o que cada um tem em comum com o outro e em que os dois diferem.

Na segunda parte, serão analisadas a complexidade e a conflituosidade das práticas de cuidados em saúde da mulher e da criança, tentando mostrar em que sentido a transformação semântica e conceitual do âmbito dessas práticas pode ser entendida como um indício desses aspectos.

Na terceira parte, será abordada a dialética entre o princípio da proteção e o princípio da autonomia pessoal, considerados os dois princípios morais mais importantes que entram em jogo no âmbito dos cuidados em saúde da mulher e da criança quando se deve enfrentar os conflitos morais que surgem nos casos do aborto e da reprodução assistida. 


\section{Ponto de Vista SANitÁrio e Ponto de Vista BioÉtico}

O objeto em foco neste livro pode ser abordado a partir de dois pontos de vista considerados pertinentes: o da saúde pública e o da Bioética laica. Os dois podem ser vistos como sendo ao mesmo tempo distintos - mas não disjuntos - e vinculados - mas não confundidos entre si nem subsumidos um ao outro -, devendo-se, portanto, encará-los numa relação que se pode definir como 'complexa' (Schramm, 1997).

Com efeito, se, por um lado, logicamente deve-se manter os dois pontos de vista distintos para não infringir a lei de Hume e evitar incorrer numa falácia naturalista - que interdita inferir normas de comportamento a partir de práticas factuais existentes, isto é, inferir o que deve (ou deveria) ser daquilo que é (ou supostamente é) - considerando também, por outro lado, que o 'saber-fazer' da saúde pública não pode, a rigor e de maneira insofismável, oferecer, intrinsecamente, sistemas normativos objetivos, capazes de avaliar - de maneira racional e imparcial - suas práticas em saúde, pode-se considerar os dois pontos de vista como logicamente complementares. E isso por duas boas razões substantivas.

Em primeiro lugar, porque os dois pontos de vista possuem pelo menos um referente comum, constituído pela preocupação compartilhada do 'bem-estar' das populações humanas (na linguagem sanitária) ou da 'qualidade de vida' (na linguagem da Bioética laica), podendo-se, portanto, considerar tal referente como um denominador comum, ainda que abordado a partir de olhares distintos (mas não separados).

Em segundo lugar, porque os dois pontos de vista podem coexistir num mesmo tipo de ator social - chamado sanitarista -, o qual também pode possuir conhecimentos específicos em filosofia moral - chamado eticista - e que deveria, a rigor, ser chamado de 'bioeticista sanitarista' ou 'sanitarista bioeticista'.

De fato, esta nova figura profissional constitui um tipo de recurso humano recém-adquirido, que algumas instituições acadêmicas tentam formar desde os anos de 1990, como é o caso da Escola Nacional de Saúde 
Pública Sergio Arouca (Ensp) e do Instituto Fernandes Figueira (IFF), ambos pertencentes à Fundação Oswaldo Cruz (Fiocruz). Em outros termos, os dois pontos de vista se coadunam para indicar um tipo de profissional que seja ao mesmo tempo competente no 'saber-fazer' sanitário e no 'saberfazer' bioético. E isso é logicamente possível porque um mesmo sujeito pode ser simultaneamente sujeito epistêmico e sujeito ético, ou seja, competente em um saber específico (neste caso, o sanitário) e em um outro saber também específico (o bioético), delineando, assim, um novo perfil profissional para a academia, para os Comitês de Ética em Pesquisa (CEPs), os Comitês de Ética Hospitalar e as várias comissões de Bioética.

No entanto, para evitar equívocos e confusões de níveis de pertinência, é importante precisar que o bioeticista (e o filósofo moral - o eticista em geral) não pode ser pensado como devendo necessariamente coincidir de fato (embora isso possa ser considerado desejável por motivos de coerência e/ou razões pedagógicas) com a pessoa moral, a qual só poderá ser considerada como tal de acordo com algum sistema de valores vigente (ou eventualmente 'emergente'). O mesmo tipo de identificação vale também, mutatis mutandis, para o sanitarista, entendido como profissional da saúde e que pode ser também a pessoa que respeita, em suas práticas cotidianas, as diretrizes e recomendações sanitárias em suas práticas como cidadão.

Em outros termos, o especialista em ética aplicada não se confunde com a pessoa que é particularmente 'ética' quando julgada devido a seus comportamentos e que poderia, portanto, ser considerada um modelo de moralidade a ser seguido: a figura do eticista e aquela da pessoa moral devem ser distintas, embora não necessariamente separados. O eticista tampouco se confunde com o moralista, que, via de regra, é aquele tipo de sujeito que diz aos outros o que deveriam fazer para poderem ser considerados 'moralmente corretos'.

Esta discrepância, factualmente sempre possível - visto que não existe necessariamente solução de continuidade entre saber algo e pô-lo em prática -, implica, evidentemente, uma série de questões que vão além da ética e da Bioética. No entanto, as mesmas não serão abordadas aqui, para não se fugir do escopo deste artigo. Mas afirmar isso, sem mais, é 
também insatisfatório, pois, para a ética - e, em particular, para a ética aplicada -, teoria e prática não podem em princípio ser disjuntas, ainda que se possa academicamente distinguir âmbitos de pertinência distintos, como as tradicionais 'teorias éticas', a 'metaética' e as várias 'éticas aplicadas', as quais - justamente por serem 'aplicadas' - deverão dar-se ao trabalho de pensar algum tipo satisfatório de vinculação entre teoria e prática; caso contrário, poderão ser legitimamente subsumidas a um dos outros âmbitos de pertinência ou serem consideradas como francamente inúteis. E este é certamente o caso da Bioética laica, como é entendida aqui, e talvez também, em alguma medida, o da saúde pública, à medida que o sanitarista é visto como um profissional capaz de entender os problemas de saúde das populações humanas e, via de regra, capaz de propor medidas para enfrentá-los concretamente e aplicá-las em sua prática - sem esta vinculação entre teoria e prática, tanto o bioeticista quanto o sanitarista se tornariam profissionais sumamente questionáveis.

Assim sendo, e considerando que um ponto de vista implica sempre, também, uma prática que não pode ser meramente teórica, nem, por assim dizer, 'desencarnada', tanto o saber sanitário como o saber bioético são, de fato, formas de 'saber-fazer', isto é, saberes que necessariamente implicam um fazer ou uma 'práxis', entendendo este último termo como a forma de agir de um agente moral sobre eventuais pacientes morais. Com efeito, o principal objetivo prático do sanitarista é saber garantir, em última instância, um certo nível de bem-estar às populações sob sua responsabilidade, desenvolvendo políticas públicas razoáveis de prevenção do adoecimento evitável, de promoção de estilos de vida considerados saudáveis e de predição do adoecimento.

Tudo isso de acordo com a competência em: 1) saber interpretar corretamente os dados biológicos e epidemiológicos confiáveis ou fidedignos; 2) avaliar os recursos efetivamente disponíveis e que devem ser eqüitativamente alocados; 3) ponderar as necessidades e os desejos legítimos da população, as necessidades específicas de grupos e indivíduos (como portadores de patologias particulares) e o que se pode chamar (com um termo talvez demasiado genérico e impreciso) a conjuntura 'global', a 
qual diz respeito às políticas internacionais de tipo econômico, de desenvolvimento, de investimento em Ciência e tecnologia, mas também a outros fatores, como o ecológico.

Portanto, pode-se dizer também que o ponto de vista sanitário tem sempre alguma forma de preocupação com a 'proteção' da saúde e do bemestar das populações humanas, as quais deverão ser consideradas em seus contextos reais, definidos, conjuntamente, pelas necessidades persistentes e emergentes, os desejos, a disponibilidade de recursos em um ambiente globalizado, amplamente definido e que pode retroagir, positiva ou negativamente, sobre uma situação sanitária específica.

Por sua vez, a Bioética de inspiração laica considera conceitualmente pertinentes e moralmente legítimos o princípio de autonomia das pessoas (que lhes outorga o direito de decidir sobre questões essenciais referentes a suas vidas) e o pluralismo democrático (consubstancial às sociedades seculares e cujas instituições devem necessariamente ser laicas). Com efeito, ambos parecem se coadunar melhor à assim chamada 'condição pósmoderna' das sociedades seculares e complexas contemporâneas (Lyotard, 1979). Nestas não vigoraria mais um único metarrelato geral capaz de dar conta, em seu conjunto, dos vários relatos particulares, nem um único paradigma ético capaz de subsumir as várias éticas específicas. Estas, de fato, constituiriam sempre uma pluralidade de sistemas, evidentemente coerentes, de valores, normas, deveres e direitos, nem sempre comensuráveis entre si a priori, mas, eventualmente, 'negociáveis' e, portanto, tão-somente válidos a posteriori, desde que também fossem respeitados, pelo menos, a desejável tolerância das diferenças ou o mais engajado reconhecimento recíproco entre agentes e diferentes comunidades morais (Taylor, 2000), considerados indispensáveis para tentar resolver as inevitáveis controvérsias destacadas pelos filósofos 'pós-modernos' (Lyotard, 1983).

Em suma, considerando que nas sociedades secularizadas e multiculturais contemporâneas é, ao menos, contra-intuitivo pressupor um único sistema de valores ou de normas morais que seja válido para todos os cidadãos e em qualquer circunstância - isto é, valores de fato 'absolutos' e supostamente 'eternos' -, a Bioética laica acaba coincidindo 
com a percepção de quem pensa que, nestes tipos de sociedades, só podem existir sistemas de comportamento e diretrizes não mais 'fortes', mas tãosomente 'fracos', pois esta seria a única maneira de resolver pacificamente seus conflitos (Vattimo \& Rovatti, 1983).

Entretanto, a forma de ética aplicada chamada Bioética - em particular, sua vertente laica - considera cognitivamente pertinente e moralmente legítimo que sua função social seja tanto de tipo analítico (ou crítico) como de tipo normativo (Mori, 2002). Ou seja, ao mesmo tempo capaz de analisar (de maneira racional e, até onde for possível, imparcial) os conflitos de interesses e valores que inevitavelmente surgem nas sociedades complexas, seculares, democráticas e pluralistas atuais; de prescrever os comportamentos desejáveis e de proscrever aqueles que podem ser considerados prejudiciais a um convívio aceitável por qualquer agente moral suficientemente racional, razoável e disposto ao diálogo e a acordos.

Por conta disso, pode-se dizer que tanto a autonomia pessoal quanto o pluralismo ético devem necessariamente ser respeitados de fato (Flamigni et al., 1996). Mas isso traz, inevitavelmente, novos problemas e desafios, pois não é intuitivamente evidente que o respeito simultâneo de todas as autonomias individuais (ou pessoais) e, conseqüentemente, a consideração imparcial de cada interesse legítimo (é isso que a princípio define uma sociedade democrática e pluralista) sejam suficientes para equacionar os conflitos que surgem em tais sociedades e que não podem, sem mais, ser resolvidos por alguma instância de autoridade válida a priori e em qualquer circunstância.

Por fim, a Bioética laica (assim como a saúde pública) se preocupa com a 'qualidade de vida' (ou 'bem-estar') tanto individual como coletiva, considerando que isso lhe outorga suficiente legitimidade social para analisar, de maneira crítica, os conflitos de interesses e de valores que surgem no tecido social e propor ferramentas normativas, razoáveis e socialmente aceitáveis, capazes de dirimir tais conflitos.

No entanto, as funções analítica e normativa da Bioética também podem ser vistas como tendo uma outra função - ao mesmo tempo anterior às duas primeiras e resultado delas (Schramm, 2002) -, que consiste em 
preservar (pela proteção dos atores envolvidos) a complexidade das sociedades democráticas contemporâneas, nas quais os conflitos de interesses e valores não podem ser dirimidos, simplesmente, a priori, pela satisfação da vontade do mais forte ou o poder da maioria, mas sim, e mais razoavelmente, a posteriori, por acordos 'pacíficos' entre os indivíduos e grupos humanos diretamente envolvidos em conflitos de interesses e valores.

Ademais, tanto o ponto de vista da saúde pública como o da Bioética laica admitem como válido que o progresso da cultura tecnocientífica constitui um bem com valor ético fundamental. Tal progresso corresponde a uma aspiração legítima do ser humano, ainda que também se possa, pertinentemente, levantar suspeitas sobre os reais benefícios, em termos de bem-estar para todos, da incorporação de ciência e tecnologia nas políticas sanitárias - sobretudo ao se considerar que muitos dos problemas em saúde pública dependem menos da incorporação de novos saberes e técnicas, mas sim da solução de antigas 'mazelas' decorrentes da situação de pobreza e exclusão social, além de dependerem da incompetência e de outras razões conhecidas, que, no entanto, não são específicas das políticas de saúde.

Assim sendo, mesmo aceitando este argumento como válido, podese também contra-argumentar alegando que o verdadeiro desafio, tanto para a saúde pública como para a Bioética laica, não é escolher entre a incorporação tecnológica e resolver os problemas decorrentes do subdesenvolvimento, mas sim agir nas duas frentes. Se o homem deixar de utilizar as possibilidades oferecidas pelas novas tecnologias, isso poderia implicar no fato de ter de responsabilizar-se pelo bem que deixa de fazer e que poderia ter feito (Harris, 1998). Este é certamente um argumento moral cogente, mesmo que deva ser mais bem equacionado tendo em conta a polêmica questão da alocação dos recursos efetivamente disponíveis em uma situação determinada. Deve-se, portanto, ponderar, em cada caso específico, a escolha entre as políticas sanitárias de vocação universalista e aquelas que privilegiam a focalização sobre populações específicas em nome da eqüidade. 
Em outros termos, esta última questão remete - de acordo $\operatorname{com} A$ Política e a Ética a Nicômaco, de Aristóteles - ao problema de como realizar concretamente a assim chamada 'virtude arquitetônica' que deve reger as relações interpessoais e cidadãs. Remete, portanto, ao ponto de vista da 'justiça' e das suas reinterpretações contemporâneas em termos de eqüidade. Ou seja, aquelas que defendem a satisfação de um 'pacote' de supostas necessidades básicas - como na teoria da justiça, de John Rawls (1997) ou aquelas que tentam corrigir a posição 'igualitária' anterior pela incorporação de legítimas aspirações individuais - como na teoria das capabilities ou 'aptidões', de Martha Nussbaum e de Amartya Sen (1996).

Desse modo, a Bioética laica considera que os progressos tecnocientífico e biotecnocientífico constituem uma legítima aspiração humana, tanto individual como coletiva. Não só porque o desejo de saber acerca do mundo e de saber sobre si mesmo é, por assim dizer, uma característica 'ontológica' do Homo sapiens sapiens, visto que "o homem, como parte da natureza, a modifica, e isso é inevitável porque o artifício faz parte da natureza, 'naturaliza-se' em continuação" (Prodi, 1989: 153-154), mas também porque o conhecimento permite, a princípio, evitar sofrimentos desnecessários e ampliar o espaço das liberdades individuais através da redução das limitações devidas à necessidade. Ou seja, porque aumenta a competência ou 'aptidão' de cada indivíduo em poder explicitar suas potencialidades e ser livre para escolher objetivos que julgar importantes e de acordo com suas aspirações, não necessariamente redutíveis a supostas necessidades básicas padrão (Sen, 1992).

Resumindo, tanto o ponto de vista da saúde pública como aquele da Bioética laica reconhecem - explícita ou implicitamente - o direito humano, válido prima facie, de transformar os fenômenos naturais, inclusive a própria natureza humana, de acordo com programas de preservação e/ou melhora do bem-estar, desde que sejam respeitadas, com responsabilidade, determinadas condições de biossegurança e de vida em comum regrada, inclusive preservando os equilíbrios necessários à qualidade de vida das gerações futuras, o bem-estar dos animais sencientes e a qualidade dos ambientes naturais. 


\section{Complexidade e Conflituosidade dos Cuidados em Saúde da Mulher e da Criança}

Como foi apresentado rapidamente na introdução, o âmbito dos cuidados em saúde da mulher e da criança é cognitivo e operativamente complexo, moralmente problemático e conflituoso. Para tentar mostrar detalhadamente em quê, por quê e como pode ser considerado complexo tanto teórica como praticamente -, pode-se, idealmente, atribuir-lhe as seguintes características dos sistemas auto-organizados complexos: "(1) a grande variedade de componentes com funções especializadas; (2) a organização desses componentes em níveis de valor diferentes; (3) a alta conectividade entre tais níveis; (4) as forças de interação entre [tais] níveis", o que permite detectar "um vínculo entre heterogeneidade dos componentes - que pode ser abordada pela multi e pluridisciplinaridade - e a homogeneidade do sistema total, dado pela mútua dependência dos subsistemas - que só pode ser abordado pela inter e transdisciplinaridade" (Schramm, 1996: 80).

Em outros termos, o subsistema da saúde pública - identificado pelo âmbito dos cuidados em saúde da mulher e da criança - pode ser definido como sendo formado (ou 'construído'), simultaneamente, por diversos 'componentes' que, por sua vez, devem ser pensados ao mesmo tempo como 'distintos' - para não perder sua especificidade ou 'identidade ontológica', nem sua pertença no nível organizacional que lhes compete e que atribui, sistemicamente, um valor diferencial ao conjunto, e que permite ter um valor informacional qualificado - e 'relacionados' - para não perder sua 'conectividade' e sua potencialidade de gerar sentido e admitir novas emergências de sentido ou 'criatividade' para enfrentar o 'novo'. Esta dupla operação pode ser sintetizada pela 'fórmula' do pensamento complexo dada por Edgar Morin e definida pelo conectivo anfibológico 'e/ou': "[o pensamento complexo] é o pensamento capaz de juntar, contextualizar, globalizar, mas também de reconhecer a singularidade, o individual, o concreto. (...) O pensamento complexo não se reduz nem à ciência nem à filosofia, mas permite a comunicação entre elas" (Morin, 1997: 95). 
Ao considerar, ao mesmo tempo, a diversidade e a especificidade de âmbitos (apontadas pelas primeira e segunda características) e suas interrelações (apontadas pelas outras duas características), pode-se referir esta caracterização complexa - indicada pelo conectivo "anfibológico" ‘e/ou' a uma série de fatos (cultural e socialmente 'construídos') da saúde materno-infantil e da saúde pública como um todo. Um primeiro fato a ser destacado é a sinergia entre persistência de antigos problemas de saúde evitáveis (derivados da falta de informação, dos estilos de vida 'nãosaudáveis' conhecidos e das condições socioeconômicas precárias, entre outras variáveis) e a emergência de novos problemas de saúde (indicados por novos possíveis determinantes no processo de adoecimento e construídos a partir de novas ferramentas teóricas e práticas para entendê-los e enfrentálos), que caracteriza a assim denominada 'hipercrise sanitária'.

Um segundo fato é o chamado 'imperativo tecnológico', supostamente independente de decisões individuais e sociais e que estruturaria a contínua e (supostamente) independente inovação científica e tecnológica - indicada pela metáfora heideggeriana Ge-stell, que tem o sentido seja de 'armação', seja de 'arrazoamento', isto é, uma espécie de lógica intrínseca à técnica, ou sua 'essência', independentemente de qualquer vontade e liberdade humana (Heidegger, 1990) - e a necessidade de incorporá-la, de forma razoável, nos procedimentos diagnósticos e terapêuticos.

Um terceiro fato é representado pela conseqüente pressão crescente sobre os recursos disponíveis - cada vez mais consensualmente considerados como finitos e escassos, implicando, portanto, uma autolimitação de nossas exigências (Callahan, 1987).

Existem, ainda, outros fatos, como aquele representado pelos riscos e eventuais perigos relacionados à manipulação da vida humana em condições de incerteza e de poder tecnológico e biotecnológico não necessariamente controlado e talvez não-controlável (Jonas, 1987). E, sobretudo, o fato de os vários tipos de know-how existentes e incipientes estarem codificados em diversas especializações - tais como pediatria, obstetrícia, genética, neonatologia, cirurgia pediátrica, medicina intensiva pediátrica, neurocirurgia pediátrica - nem sempre concretamente integradas 
em um 'saber-fazer' comum, seja porque não traduzidas numa linguagem inteligível para o especialista de uma outra disciplina, seja porque não integradas em uma prática comum. Por tudo isso, considera-se pertinente afirmar que o âmbito dos cuidados em saúde da mulher e da criança é um representante significativo da chamada 'complexidade sanitária'.

O âmbito dos cuidados em saúde da mulher e da criança é também problemático - teórica e praticamente - do ponto de vista da Bioética laica, porque a nova dupla competência - consistente em saber entender cada vez mais os mecanismos intrínsecos dos processos vitais e em intervir neles para transformá-los e até recriá-los de acordo com nossos projetos parece estar apontando para uma verdadeira revolução antropológica, com conseqüências ainda incalculáveis e que, talvez, só possa ser concebida provisoriamente e de forma metafórica como um 'Jano de duas faces' (Schramm, 2000). Metáfora que indica uma situação inicial e incerta, que pode evoluir para o aprimoramento das potencialidades positivas do humano ou, ao contrário, para as negativas e destrutivas.

Ainda não é possível vislumbrar os prováveis rumos de tal revolução e, menos ainda, compreendê-la suficientemente em suas várias e articuladas conexões (complexidade), nem em suas implicações morais e éticas (conflituosidade). Isso se deve a dois motivos: 1) porque talvez se estejam reconfigurando conceitualmente e ressemantizando as tradicionais categorias filosóficas de vida e morte, corporeidade e espiritualidade, natureza e cultura, doença, sofrimento e saúde (Piana, 2002); 2) porque, talvez, os homens sejam ainda incapazes de traduzir esta competência logotécnica em ferramentas operativas, isto é, fidedignas e confiáveis, que possam responder aos anseios humanos, à sua vulnerabilidade e ao seu desamparo, sempre presentes, apesar do crescente poder tecnocientífico e biotecnocientífico adquirido, que parece transformar o Homo sapiens sapiens em Homo creator - ser capaz de transformar a si mesmo em mero ente ou matéria-prima, podendo tornar-se, assim, pela sua própria prática desconsiderada, um ser literalmente 'obsoleto' (Anders, 1992).

De fato, nas sociedades complexas, seculares, democráticas e pluralistas contemporâneas, este tipo de revolução 'total' (no sentido de 
implicar praticamente todas as dimensões do humano e do ser, por princípio não redutível à dimensão de puro ente ou 'coisa') traz como conseqüências: 1) 'cosmovisões' (Weltanschauungen) não necessariamente comensuráveis entre si (pelo menos não a priori, mas, eventualmente, a posteriori); 2) sistemas de valores e interesses contrastantes e que podem excluir-se mutuamente no caso de conflitos de interesses e, sobretudo, diante de autênticos dilemas morais; 3) emoções e razões dificilmente integráveis; 4) concepções diferentes sobre o que pode ser considerado ético ou nãoético, justo ou injusto, virtuoso ou vicioso, moral ou amoral ou imoral, e sobre os vários referentes possíveis desses conceitos, divergindo, inclusive, sobre o sentido das palavras a serem utilizadas em cada operação cognitiva requerida em uma situação moral específica, como será apresentado a seguir.

\section{Saúde Materno-lnfantil ou Saúde da Mulher e da Crianca?}

Um indício que parece sintetizar bastante bem a complexidade e problematicidade do objeto aqui em foco é o fato de que a tradicional denominação hifenizada 'saúde materno-infantil' (que ainda aparece no portal do IFF, definido como 'unidade materno-infantil da Fiocruz') vem sendo acompanhada - quando não paulatinamente substituída - pelas expressões não-hifenizadas 'saúde da criança, da mulher, do adolescente e da família' e 'saúde da criança e da mulher numa perspectiva interdisciplinar', quando referidas às atividades de ensino e de pesquisa (IFF/Fiocruz, 2004).

Esta transformação lexical parece ser indício de uma mutação semântica, a qual, por sua vez, poderia estar indicando que se está passando de uma denominação tradicional, que simplificava - amalgamando sem mais - os vários tipos de problemas envolvidos pela 'saúde materno-infantil' (e os saberes específicos necessários para enfrentá-los) e os vários, e não necessariamente coincidentes, interesses dos diversos atores envolvidos (criança, mulher, adolescente, família), para uma nova denominação que, ao contrário, abre a possibilidade de considerar a real complexidade do campo; a variabilidade e o antagonismo dos interesses e sistemas de valores 
dos diferentes atores participantes; e seu caráter moralmente conflituoso e às vezes dilemático. Mas, se o que se está afirmando é uma interpretação correta de um fato que está ocorrendo, isso parece requerer fazer apelo a um pensamento não-reducionista, isto é, complexo, que teria - no estágio atual de nossos conhecimentos - uma maior probabilidade de dar conta das características pertinentes do conjunto 'saúde da criança, da mulher, do adolescente e da família'.

Existem, provavelmente, muitas outras razões - historicamente qualificadas - que permitem entender esta mutação lexical e semântica e o fato de ela ser o possível indício de uma verdadeira transformação em curso deste âmbito concreto do campo da saúde. Mas a intenção deste texto não é tentar aprofundar esta questão (até porque, certamente, não se tem a competência necessária para esta tarefa historiográfica ou arqueológico-genealógica). O que se quer - mais realisticamente - ressaltar é que todas essas possíveis razões e explicações dizem respeito a problemas ao mesmo tempo distintos e relacionados, mas que podem também ser encarados a partir de um duplo ponto de vista: o ponto de vista sanitário (ou da saúde pública) e o ponto de vista bioético (ou mais precisamente da Bioética laica), sem, com isso, pretender substituir outros pontos de vista, igualmente pertinentes, e que já fazem parte - de direito e de fato - da tradição da cultura sanitária.

Com efeito, do ponto de vista da saúde pública, é possível relembrar: 1) a transição epidemiológica em curso nas sociedades contemporâneas (redução da mortalidade materno-infantil, relativo aumento da esperança de vida, aparente redução da incidência das doenças infecto-contagiosas e aumento das doenças crônico-degenerativas); 2) o avanço do conhecimento científico e técnico no campo das ciências da vida e da saúde; 3) a complexificação e a inevitável especialização dos saberes, assim como a conseqüente necessidade de colocá-los em relação entre si, recorrendo à metodologia da multi, pluri, inter e transdisciplinaridade que em princípio permitiriam não perder de vista o todo; 4) a carga cada vez mais insustentável da saúde pública sobre os orçamentos de praticamente todas as nações que dispõem de algum sistema 
minimamente racional e aceitável de prevenção e proteção da saúde de seus cidadãos, entre outras.

Já do ponto de vista da Bioética laica, pode-se relembrar: 1) a secularização progressiva dos valores éticos e dos sistemas de valores em geral - característica das sociedades multiculturais e multiconfessionais contemporâneas -; 2) a formação de um imaginário social cada vez mais atravessado por exigências cidadãs e pela chamada cultura dos direitos naturais, humanos, sociais, das gerações futuras, entre outros ; 3) o suposto narcisismo individualista contemporâneo e sua pretensa e 'endêmica' incapacidade crescente de lidar com o sofrimento e as frustrações inevitavelmente implicadas pela vida em comum - sintetizáveis pela expressão de uma 'sociedade sem dor' - e que podem ser interpretadas como uma autêntica 'transição paradigmática em ética' (Almeida \& Schramm, 1999).

\section{Reproducão Assistida e Abortamento à lUZ da DialÉTICA ENTRE Autonomia e Proteç̃o}

Entretanto, todas as razões anteriormente mencionadas, provavelmente pertinentes quando referidas às profundas transformações advindas nas sociedades contemporâneas a partir da segunda metade do século XX - aqui apontadas pelo termo sintético de 'revolução antropológica' - parecem ser insuficientes, isto é, não substantivas e sui generis, quando referidas ao campo tradicionalmente definido como o da 'saúde materno-infantil'. Como foi visto, define-se de maneira mais pertinente e atualizada como 'saúde da mulher e da criança', 'cuidados em saúde da mulher e da criança' ou 'cuidados em saúde da mulher, da criança, do adolescente e da família'.

De fato, neste caso, o imaginário transformador parece ser muito melhor indicado pelo fenômeno (ao mesmo tempo individual e social) que, a partir dos anos de 1960, viu emergir uma série de movimentos reformadores e até revolucionários, tais como o movimento feminista ou das mulheres; o movimento dos direitos humanos e civis; o movimento 
ecologista; o movimento dos 'direitos' dos animais (ou do 'bem-estar' animal) e o próprio 'movimento da Bioética' (Mori, 1994). Este último, em campo moral, constitui uma espécie de síntese de todos os outros, se é verdade - como se pensa - que representa uma autêntica transição paradigmática em ética (Almeida \& Schramm, 1999).

Na prática, esses movimentos (reformadores ou revolucionários) se concretizaram em uma série de lutas, como as lutas das mulheres pelos direitos reprodutivos e, em geral, pelo poder de decidir 'autonomamente' e a 'autogestão' do próprio corpo - sintetizado pelo neologismo 'empoderamento' (enpowerment) - e pela distinção entre sexualidade e reprodução, explicitada pelo direito de ter ou não ter filhos, quando tê-los e como, inclusive recorrendo aos meios da reprodução assistida e, quando julgado necessário e como produto de uma decisão consciente, à prática do abortamento.

No entanto, as transformações culturais e sociais em ato (nesta possível 'revolução antropológica') implicam não somente a manipulação da biologia humana propriamente dita - com possíveis efeitos imediatos sobre os delicados equilíbrios que regulam qualquer processo vital -, mas também uma inevitável e profunda transformação do sentido da vida humana (como parece ser o caso da saúde reprodutiva e, em particular, o âmbito dos cuidados em saúde da mulher e da criança).

Esta transformação 'antropo-biológica' pode ter um impacto significativo sobre o capital simbólico acumulado ao longo do tempo e codificado em normas e rituais aparentemente consolidados. É razoável, portanto, pensar que a ruptura com o passado não é somente de tipo técnico (ou tecnocientífico e biotecnocientífico) - eventualmente no sentido de uma 'imposição' ao antropos vinda de 'fora' dele na modalidade da 'armação' heideggeriana -, mas também, e talvez de maneira mais radical, uma ruptura que envolve "a esfera íntima do humano e (...) a questão do sentido" (Piana, 2002: 13).

Reprodução assistida e abortamento são certamente dois problemas importantes tanto para a saúde pública como para a Bioética, ainda que não esgotem todo o campo dos complexos e conflituosos problemas morais dos 'cuidados em saúde da mulher, da criança, do adolescente e da família'. 
Contudo, aqui eles são considerados como dois paradigmas constitutivos da Bioética do começo da vida, pois envolvem a chamada 'dialética entre princípio da autonomia e princípio da proteção'.

\section{OS DOIS PARADIGMAS DO ABORTO E DA REPRODUCÃO ASSISTIDA}

Pode-se falar em 'paradigma' não no sentido técnico de 'matriz disciplinar', mas de 'modelo' (Kuhn, 1962), porque tanto o aborto como a reprodução assistida constituem 'temas' (themata) geradores de controvérsias (Holton, 1973) entre os mais debatidos e polêmicos da história da Bioética. Em particular, o aborto pode ser considerado ainda hoje como "uma verdadeira controvérsia moral (...) uma das poucas capazes de provocar profundas divisões sociais, comparável somente às guerras religiosas" (Mori, 1997). A reprodução assistida, por sua vez, é também um dos temas mais debatidos atualmente, sobretudo quando se pensa em um de seus possíveis desdobramentos mais polêmicos: a clonagem humana reprodutiva, praticamente condenada universalmente, seja por razões de biossegurança, seja por razões éticas, mas que, de fato, permanece uma questão a ser mais bem analisada e avaliada, principalmente levando em conta as esperanças e promessas regenerativas de órgãos e tecidos com a incipiente biotecnologia das células-tronco (Schramm, 2003a).

Apesar de aborto e reprodução assistida terem o denominador comum de referirem-se à liberdade reprodutiva (e a alguma forma de limitação dela), é possível situá-los conceitualmente também em pólos opostos no âmbito mais restrito da saúde da mulher e da criança, pois a reprodução assistida diz respeito à questão da liberdade reprodutiva e do desejo da mulher de ter filhos, ao passo que o aborto diz respeito à liberdade reprodutiva no sentido de respeitar o desejo de não tê-los. Em suma, no caso do aborto, tem-se uma "liberdade de não procriar" ou "liberdade negativa" e, na reprodução assistida, uma "liberdade de procriar" ou "liberdade positiva" (Mori, 2001: 57 - grifos do autor).

O reconhecimento de ambos os tipos de liberdades é fato historicamente bastante recente e representa uma das conquistas mais 
importantes do movimento em defesa dos direitos civis da segunda metade do século XX, quando, nas sociedades seculares ocidentais, afirma-se uma cultura moral fortemente moldada pelo princípio da autonomia individual e se aceita a separação entre sexualidade e reprodução, e - de forma mais geral - o direito da pessoa decidir sobre o que fazer com seu corpo, a tal ponto que hoje se admite que os dois tipos de liberdade podem pertencer a um mesmo direito civil fundamental relativo à pessoa humana.

No entanto, existem também oposições e tentativas de restringir e até de proibir ambos os tipos de liberdade, baseando-se em vários tipos de argumentos morais. Eles vão desde as proibições absolutas de tipo religioso - inclusive sua variante consistente na proibição de 'fazer o papel de Deus' (playing God) - e a proibição de interferir nos processos teleológicos naturais, passando pela proibição em prol da defesa dos direitos do ente presumivelmente mais frágil e desprotegido, o qual pode ser - em algumas interpretações - indiferentemente o feto (independentemente de seu estágio de desenvolvimento), o embrião ou o pré-embrião, e vão até argumentos aparentemente menos cogentes, como aqueles que consideram, por exemplo, moralmente ilícita e até 'fútil' a reprodução diante da possibilidade de adoção de crianças e recém-nascidos abandonados em nome do amor ao próximo ou da solidariedade social. Todos esses argumentos têm também seus contra-argumentos cogentes, mas que não podem ser aqui apresentados porque este capítulo pretende limitar-se a abordar o argumento 'naturalista' por ser considerado o mais genuinamente polêmico do ponto de vista da Bioética laica aqui adotado.

\section{Naturalidade E ANTINATURAlidAdE DA REPRODUÇ̃̃O ASSISTIDA E DO ABORTO}

Embora reprodução assistida e aborto se refiram a práticas que tentam corrigir um processo que pode ser considerado natural (a infertilidade, no primeiro caso, e a gravidez, no segundo), visto que tanto a infertilidade quanto a gravidez indesejada fazem parte da condição humana, pode-se argumentar que ambas colocam a questão, moralmente relevante, 
de saber se o humano pode ou não infringir uma lei natural (ou suposta como tal), e se isso pode ser traduzido em termos de direitos humanos.

No primeiro caso, tem-se implicitamente um direito 'positivo' referido ao fato de querer criar vida a partir dos meios fornecidos pela Ciência e a técnica, ao passo que, no segundo, há um direito 'negativo' referido ao fato de querer suprimir uma vida ou evitar que uma vida (indesejada) se desenvolva, de acordo com a própria filologia da palavra aborto, cujo sentido é 'não-nascido' (do latim abortus, particípio passado de aboriri, formado pelo prefixo privativo ab e o verbo oriri, que significa 'nascer').

Assim sendo, seria possível inferir que tanto a reprodução assistida quanto o aborto correspondem a processos antinaturais. Este argumento é muitas vezes utilizado por aqueles que se opõem a ambas as práticas, inclusive por aqueles que julgam que uma vida é, por princípio, melhor do que uma morte ou uma não-vida, ou ainda - utilizando um antigo argumento filosófico que remonta a Parmênides - que o Ser é sempre preferível ao Nada.

Entretanto, a reprodução assistida e o aborto podem ser encarados como práticas muito menos antinaturais do que parecem, apesar do fato de ambas serem também necessariamente inscritas na ordem simbólica, na qual os seres humanos se reproduzem e se sucedem e que lhes permite ocupar seus lugares específicos de mãe, pai e filho(a), em um processo que não pode ser reduzido à mera reprodução biológica da espécie.

Com efeito, a reprodução assistida pode ser vista, mutatis mutandis, como o incremento de uma competência que, via de regra, a mulher tem 'naturalmente', isto é, a competência biológica, emocional e racional de escolher o momento fértil para engravidar ou, ao contrário, o momento não-fértil para exercer sua sexualidade e evitar uma gravidez indesejada. Nesse sentido, a reprodução assistida pode ser vista como um aprimoramento, pela Ciência e a técnica, de uma competência já possuída 'naturalmente' pela própria mulher. Por sua vez, o aborto é também um processo que pode ser visto como 'natural' se for levado em conta que, estatisticamente, nem todos os óvulos fecundados originarão um novo ser, acontecendo, de fato, muitos abortos espontâneos, isto é, não- 
intencionais e, portanto, que podem ser vistos como pertencentes à ordem natural das coisas. Parece, assim, que o argumento 'naturalista' não permite 'desempatar' a questão da licitude, ou não, do aborto e da reprodução assistida.

\section{Para alÉm do debATE NATURALIDADE/ANTINATURALIDADE}

A argumentação se complica se, ao invés de enfocar-se a 'naturalidade' como elemento pertinente para enfrentar a moralidade da reprodução assistida e do abortamento, pensar-se, ao contrário, estas duas práticas a partir da ordem simbólica constitutiva do humano e, em particular, a partir da característica peculiar do Homo sapiens sapiens, que é a moralidade constitutiva de seu ser e que pode ser vista até como parte da própria biologia humana (Prodi, 1989; Schramm, 1996; Atlan, 2002).

Com efeito, neste caso, os dois problemas devem ser considerados a partir de outros parâmetros, que são de tipo moral, como: 1) o problema da antinomia entre 'princípio da sacralidade da vida' versus 'princípio da qualidade da vida' (Singer, 1983) , isto é, perguntando se a vida deve ser sempre preservada ou se devem ser preservadas tão-somente determinadas formas dela; 2) o problema de saber qual estatuto deve-se necessariamente atribuir - ou pode-se razoavelmente atribuir - a gametas, óvulos, préembriões, embriões, fetos e recém-nascidos (Schramm, 2003a; 2003b); 3) o problema do conflito de interesses entre uma pessoa que tem por princípio 'direitos atuais' (como a gestante) e uma 'pessoa' que, de fato, ainda não é pessoa e só pode, portanto, ter 'direitos potenciais', como é o caso de embriões e fetos, que podem também não se tornar pessoas atuais por não nascerem nunca, mas cuja vida mereceria ser considerada um 'bem jurídico' a ser protegido (Dallari, 2004), entre outros tantos problemas que não podem ser aqui analisados detalhadamente. Entretanto, uma maneira de não evitar todos esses problemas consiste em subsumi-los àquela que, aqui, é considerada a questão moral principal abordada: a 'dialética entre autonomia e proteção'. 


\section{A DIALÉTICA ENTRE PRINCÍPIO DA AUTONOMIA E PRINCÍPIO DE PROTECÃO}

Quando Friedrich Nietzsche (2000) sintetizou a condição humana de seu tempo (final do século XIX), utilizando a metáfora do 'humano demasiado humano' para indicar o humano atrelado a suas limitações e a seus 'ressentimentos' contra a vida, queria mostrar também que esta condição não seria necessariamente perpetuável e que, 'para espíritos livres', pode ser ultrapassada, atingindo, desta maneira, um novo patamar de humanização, em que o homem tentaria ser um autêntico ser livre - o que ele sintetizou pela imagem do Sobre-homem ou Ultra-homem (Übermensch). Em outros termos, ao mesmo tempo em que o filósofo alemão - considerado por muitos como um autêntico precursor de muitos dos temas e movimentos que marcaram o século XX - estigmatizava as limitações humanas, indicava também um possível caminho para libertar-se delas: o caminho para a evolução do humano à condição talvez 'pós-humana'.

A dialética entre proteção e autonomia tem a ver com este processo evolutivo de possível aprimoramento do Sobre-homem. De fato, o 'princípio de proteção' é, provavelmente, o mais antigo princípio moral conhecido existente na cultura ocidental, pois se refere, possivelmente, à primeira ocorrência escrita da palavra grega ethos, a qual já se encontra nos poemas homéricos com o significado de 'guarida' ou 'abrigo', e que remete, justamente, ao sentido de 'proteção' (Schramm \& Kottow, 2001).

Assim sendo, 'proteger' (muito próximo semanticamente de 'cuidar') refere-se a um tipo de relação humana particular de reconhecimento, cujo modelo pode ser detectado na relação buberiana 'eu-tu' (Buber, 1974) diferente, por exemplo, da agressão e da autodefesa existentes basicamente no modelo 'eu-outro', entendendo o outro não no sentido de quem merece a consideração de seu semelhante e que o obriga moralmente a se ocupar dele, mas o outro entendido como quem pode eventualmente ameaçá-lo e que diz respeito às práticas que fazem com que o Homo sapiens sapiens não passe, no fundo, de um mamífero, o qual, em condições 'normais', cuida de suas crias, por assim dizer, 'naturalmente'. Já o 'princípio de 
autonomia' é, provavelmente, o princípio moral que rege as inter-relações humanas mais recentes na evolução da cultura moral ocidental, pois foi codificado, de fato, a partir da Idade Moderna para dar conta da emergência da figura do indivíduo e de seus direitos frente ao grupo, à comunidade e ao Estado (Segre, Silva \& Schramm, 1998).

De fato, na situação complexa e crescentemente conflituosa das inter-relações humanas, a tensão - à primeira vista não eliminável - entre os princípios da proteção e da autonomia incita a pensá-los e a aceitá-los como dois pólos co-necessários de uma 'dialética', que diz respeito tanto à condição 'demasiadamente humana' (que precisa de 'proteção') quanto à possibilidade de ultrapassá-la pela evolução rumo a um patamar de moralidade atento não só aos deveres e obrigações impostos pelo grupo à comunidade e à sociedade, mas também aos direitos dos indivíduos (representados aqui pelo princípio de 'autonomia', que é a versão moderna do antigo princípio de 'autarquia' desenvolvido no âmbito da pólis grega).

Em outros termos, como escreve Norberto Bobbio (1992: 57):

[se o] problema da moral foi originariamente considerado mais do ângulo da sociedade que daquele do indivíduo [visto que] aos códigos de regras de conduta foi atribuída a função de proteger mais o grupo em seu conjunto do que o indivíduo singular, [para se poder passar] do código dos deveres para o código dos direitos (...) o problema da moral [deve] ser considerado não mais do ponto de vista apenas da sociedade, mas também daquele do indivíduo.

\section{CONCLUSÕES}

Os dois princípios bioéticos da proteção e da autonomia (o princípio ético mais antigo e o mais recente), quando referidos ao âmbito dos cuidados em saúde materno-infantil ou da 'saúde da mulher e da criança', abrem a possibilidade de pensar-se este âmbito de maneira 'dialética' no sentido próprio deste termo.

Com efeito, no caso da relação entre proteção e autonomia, pode-se considerar que esta última surge - como princípio moral - como uma 
tentativa de ultrapassar o antigo princípio da proteção, de acordo com o individualismo moderno. Isso é bastante claro, no campo da saúde, ao se considerar que o princípio de autonomia vem, paulatinamente, se opondo aos tradicionais princípios de beneficência e não-maleficência que, em muitos casos (como em muitas situações da relação médico-paciente), se identificam com um verdadeiro 'paternalismo', consistente na infantilização do outro, e que hoje é cada vez mais criticável e criticado, inclusive pela cultura dos direitos humanos. Em suma, a vigência do princípio de autonomia corresponderia ao momento 'antitético' de emergência do Sobre-humano nietzschiano sobrepujando a antiga condição 'demasiadamente humana', representada pela sobrevivência do princípio de proteção, identificado com o 'paternalismo', ou pela tese relativa à tradicional relação 'eu-tu'.

No entanto, existe também, atualmente, um movimento de recuperação e ressemantização da palavra 'proteção', sobretudo no campo da saúde e, em particular, da saúde pública. Isso é possível porque a ressemantização desta palavra consiste, em substância, em considerar a pertinência moral da 'autonomia', mas em considerar também que sua pertinência - como para qualquer outro princípio moral numa sociedade secular e pluralista - só vale de maneira não absoluta, pois em muitos casos (nos quais a competência ao real exercício da autonomia pode ser razoavelmente questionada) pode-se recuperar o princípio de proteção como uma maneira de garantir os interesses do indivíduo particularmente vulnerável ou desamparado, como podem ser crianças, recém-nascidos, gestantes e puérperas, até que adquiram a competência autonomista ou a recuperem.

Concluindo, tanto do ponto de vista dos cuidados em saúde da mulher e da criança como daquele da Bioética laica e secular, pode-se dizer que existe de fato uma dialética entre os dois princípios da proteção e da autonomia. Por um lado, a proteção visa a dar ao indivíduo ou à população de indivíduos - objeto da proteção - as condições necessárias para adquirir a competência da autonomia e poder exercê-la (o que também é, em última análise, uma maneira de responsabilizá-los pelas suas escolhas e práticas); 
por outro, a proteção - ao incorporar em suas finalidades o aprimoramento da autonomia - acaba garantindo, a princípio, o bem-estar e a qualidade de vida de seus 'protegidos', justamente por preservar e garantir que eles se tornem cada vez mais autônomos em suas escolhas sobre o que lhes diz respeito. Nesse sentido, não existe mais oposição entre os dois princípios, mas sim uma relação chamada aqui de 'dialética'. Esta hipótese deve, evidentemente, ser verificada - por confirmação ou refutação - pelas práticas concretas no âmbito dos cuidados em saúde da mulher e da criança. Mas esta é uma outra questão.

\section{ReFERÊNCIAS BiBLIOGRÁfiCAS}

ALMEIDA, J. L. T. \& SCHRAMM F. R. Paradigm shift, metamorphosis of medical ethics, and the rise of bioethics. Reports in Public Health/Cadernos de Saúde Pública, 15(1): 15-25, 1999.

ANDERS, G. Die Antiquiertheit des Menschen II. Über die Zerstörung des Lebens im Zeitalter der dritten industrielle Revolution. München: CH Beck Verlag, 1992.

ATLAN, H. La Science Est-elle Inhumaine? Essai sur la libre necessite. Paris: Bayard, 2002.

BObBiO, N. A Era dos Direitos. Rio de Janeiro: Campus, 1992.

BUBER, M. Ich und Du. Leipzig: Insel Verlag, 1974.

CALLAHAN, D. Setting Limits: medical goals in an aging society. New York: Simon \& Schuster, 1987.

DALlARI, D. Bioética e direitos humanos. Disponível em: http:// www.dhnet.org.br/direeitos/militantes/dalmodallari/dallari_Bio.htm. Acesso em: 12 fev. 2004.

FEINBERG, J. The rights of animals and unborn generations. In: BLACKSTONE, W. T. (Org.) Philosophy and Environmental Crisis. Athens GA: University of Georgia Press, 1974.

FLAMIGNI, C. et al. Manifesto di bioética laica. Sole 24 Ore. jun. 1996. 
HARRIS, J. Clones, Genes and Immortality: ethics and the gene revolution. Oxford: Oxford University Press, 1998.

HEIDEGGER, M. Die Frage nach der Technik. In: Vorträge und Aufsätze. Pfullingen: Günther Neske Verlag, 1990.

HOLTON, G. Thematic Origins of Scientific Thought. Cambridge MA: Harvard University Press, 1973.

INSTITUTO FERNANDES FIGUEIRA/FUNDAÇÃO OSWALDO CRUZ (IFF/ FIOCRUZ). Pós-Graduação em Saúde da Criança e da Mulher. Disponível em: http://www.iff.fiocruz.br. Acesso em: 21 jan. 2004.

JONAS, H. Technik, Medizin und Ethik: Práxis des prinzips verantwortung. Frankfurt: Suhrkamp Verlag, 1987.

KOTTOW, M. Bioética del comienzo de la vida. ¿Cuántas veces comienza la vida humana? Bioética, 9(2): 25-42, 2001.

KUHN, T. S. The Structure of Scientific Revolution. Chicago: Chicago University Press, 1962.

LYOTARD, J. F. La Condition Postmoderne: rapport sur le savoir. Paris: Editions de Minuit, 1979.

LYOTARD, J. F. Le Différend. Paris: Editions de Minuit, 1983.

MORI, M. A Bioética: sua natureza e história. Humanidades, 9(4): 333$341,1994$.

MORI, M. A Moralidade do Aborto: sacralidade da vida e o novo papel da mulher. Brasília: UnB, 1997.

MORI, M. Fecundação assistida e liberdade de procriação. Bioética, 9(2): $57-70,2001$.

MORI, M. Bioética: 10 temi per capire e discutere. Milano: Edizioni scolastiche Bruno Mondadori, 2002.

MORIN, E. Le besoin d'une Pensée Complexe. In: MENDES, C. (Org.) Représentation et Complexité. Rio de Janeiro: Educam/Unesco/ISSC, 1997.

NIETZSCHE, F. Menschliches, Allzumenschliches. [1876]. Frankfurt a/ Main: Insel Verlag, 2000. 
NUSSbAum, M. \& SEN, A. La Calidad de Vida. México: Fondo de Cultura Econômica, 1996.

PIANA, G. Bioética: alla ricerca di nuovi modelli. Milano: Editore Garzanti, 2002.

PRODI, G. L'individuo e la sua Firma. Bologna: Il Mulino, 1989.

RAWLS, J. Uma Teoria da Justiça. São Paulo: Martins Fontes, 1997.

RODEN, N. Cesareans and samaritans. Law, Medicine and Health Care, 15: $118-125,1987$.

SCHRAMM, F. R. A Terceira Margem da Saúde: ética natural, complexidade, crise e responsabilidade no saber-fazer sanitário. Brasília: UnB, 1996.

SCHRAMM, F. R. Eugenia, eugenética e o espectro do eugenismo. Considerações atuais sobre biotecnociência e Bioética. Bioética, 5(2): 203-220, 1997.

SCHRAMM, F. R. Genética: um Jano de duas faces? In: GARRAFA, V. \& COSTA, S. I. (Orgs.) A Bioética no Século XXI. Brasília: UnB, 2000.

SCHRAMM, F. R. Bioética para quê? Revista Camiliana da Saúde, 1(2): 14$21,2002$.

SCHRAMM, F. R. A clonagem humana: uma perspectiva promissora. In: ARRAFA, V. \& PESSINI, L. (Orgs.) Bioética: poder e injustiça. São Paulo: Loyola, 2003a.

SCHRAMM, F. R. Bioética de la protección, vulnerabilidad y amenaza desde una perspectiva laica. Diálogo Político, I(1): 33-48, 2003 b.

SCHRAMM F. R. \& KOTTOW, M. Princípios bioéticos en salud pública. Cadernos de Saúde Pública, 17(4): 949-956, 2001.

SEGRE, M. \& SCHRAMM, F. R. Quem tem medo das (bio)tecnologias de reprodução assistida? Bioética, 9(2): 43-56, 2001.

SEGRE, M.; SILVA, F. L. \& SCHRAMM F. R. O contexto histórico, semântico e filosófico do princípio de autonomia. Bioética, 6(1): 15-25, 1998.

SEN, A. K. Inequality Reexamined. Oxford: Oxford University Press, 1992.

SINGER, P. Sancity of life or quality of life? Pediatrics, 72: 128-129, 1983. 
STEINBOCK, B. Life Before Birth: the moral and legal status of embryos and fetuses. New York: Oxford University Press, 1992.

TAYLOR, C. A política do reconhecimento. In: TAYLOR, C. (Org.) Argumentos Filosóficos. São Paulo: Loyola, 2000.

VATTIMo, G. \& ROVATTI, P. A. Il Pensiero Debole. Milano: Editore Feltrinelli, 1983. 


\section{Deontologia e AssistênCia MATERNO-lNFANTIL}

\section{3}

José Luiz Telles

Ana Paula Abreu Borges

\section{INTRODUCÃO}

As aplicações tecnológicas em saúde, aliadas às novas demandas sociais, em particular na área da assistência materno-infantil, têm colocado sérios desafios éticos para a prática dos profissionais em saúde. A Bioética tem sido um recurso importante para a reflexão e prescrição de ações moralmente justificáveis perante a sociedade. Isso não quer dizer, no entanto, que os códigos de ética profissionais ou códigos de deontologia profissional tenham perdido sua validade. A ética profissional, consubstanciada nos diferentes códigos deontológicos, representa um subconjunto da Bioética, isto é, a ética deontológica está inserida no campo maior de análise moral que é a Bioética.

Este artigo tem por objetivo discutir o âmbito conceitual e de aplicação da deontologia profissional e explicitar algumas questões que envolvem o dever do profissional da saúde perante a assistência maternoinfantil. Além dos códigos de ética das diferentes profissões em saúde, os temas suscitados por declarações internacionais e, em particular, pelo Estatuto da Criança e do Adolescente (ECA) em vigor no Brasil, são discutidos na medida em que trazem desafios éticos importantes para as profissões em saúde.

Na primeira parte, delimitou-se o conceito de deontologia buscando caracterizar sua importância para a 'boa' prática profissional. Não se trata de uma discussão de cunho filosófico, mas que tão-somente visa a 
estabelecer os limites que a deontologia possui para a reflexão sobre os conflitos e dilemas morais contemporâneos referentes às práticas no campo das ciências da vida e da saúde. Em um segundo momento, buscou-se trazer para a realidade brasileira alguns desafios que se impõem no plano da assistência materno-infantil, tendo por referência alguns deveres profissionais postos por legislações específicas, declarações ou consensos internacionais.

\section{A Deontologia e as Profissóes em Saúde}

A etimologia da palavra deontologia vem do grego déontos, que significa 'o que é obrigatório, necessário', acrescido do termologia, que, do grego logos, significa 'discurso' e 'estudo'. Tendo por referência sua etimologia, a deontologia pode ser entendida - de acordo com o dicionário - como "1. o estudo dos princípios, fundamentos e sistemas de moral; 2. Tratado dos deveres" (Ferreira, 2003).

Correntemente se fala da deontologia ou 'ciência dos deveres', em sentido jurídico, como uma extensão do direito profissional. Daí que é comum a palavra deontologia vir acompanhada de adjetivo que designa profissão. Dessa maneira, como afirma Sandro Spinsanti (1990: 11), a deontologia chamaria a "atenção para a conveniência ou a necessidade de que a profissão tenha determinadas características, as quais constituem o estilo de seu exercício". A deontologia se ocuparia, então, de um conjunto de regras tradicionais que indicam como alguém deverá se comportar na qualidade de membro de um determinado corpo social. Este conjunto de regras é definido pela própria corporação profissional.

A primeira atividade social a instituir um corpo de normas e deveres foi a medicina. A partir de Hipócrates de Cós (460-390 a.C.), fundamentamse as bases da ética tradicional da medicina, ordenadas no Juramento Hipocrático e nos livros deontológicos ou normativos do Corpus Hippocraticum. No juramento, o médico comprometia-se a: 1) usar a medicina em benefício dos pacientes; 2) manter sigilo sobre os fatos ocorridos com seus pacientes; 3) conservar em segredo os conhecimentos médicos, 
exceto para os seus pares; 4) não manter relações sexuais com os pacientes; 5) não administrar substâncias que poderiam levar à morte ou provocar efeitos abortivos (Souza, 1981; Keyserlingk, 1998).

A instituição de um código deontológico foi de fundamental importância para o reconhecimento e a credibilidade pública da prática profissional, na medida em que esse compromisso é firmado publicamente por meio de um juramento. O primeiro código profissional moderno foi instituído pela Associação Médica Norte-Americana, em 1847, e, após diversas revisões, acabou servindo de modelo não só para as corporações médicas no mundo inteiro como também para as outras profissões em saúde.

No ano de 1867, a Gazeta Médica da Bahia publicou o "Código de Ethica Medica Adoptado pela Associação Medica Americana". Somente em 1931 é que surge a primeira iniciativa de se instituir um código de ética próprio no Brasil. No I Congresso Médico Sindicalista, o Código de Deontologia Médica foi elaborado e tornado público no Boletim do Syndicato Médico Brasileiro.

Em 24 de outubro de 1945, o IV Congresso Sindicalista Médico Brasileiro aprovou o Código de Deontologia Médica, oficializado como Anexo pelo Decreto-Lei n. 7.955, de 13 de setembro de 1945, revogado posteriormente pela Lei n. 3.268, de 30 de setembro de 1957. Esta lei foi assinada pelo então presidente da República, e médico de formação, Juscelino Kubitschek, e instituía os Conselhos de Medicina (França, 1994a).

Em seu artigo 30, a Lei n. 3.268 determinou a adoção do Código de Ética da Associação Médica Brasileira, aprovado na IV Reunião do Conselho Deliberativo da entidade, ocorrida no Rio de Janeiro em 30 de janeiro de 1953, até que o Conselho Federal de Medicina elaborasse o seu próprio. Esta situação perdurou até 24 de setembro de 1964, quando foi aprovado o primeiro Código de Ética do Conselho Federal de Medicina, o qual foi publicado no Diário Oficial da União, de 11 de janeiro de 1965.

A partir de então, todas as profissões em saúde, para se regulamentarem, têm, por lei, a obrigação de instituir um conselho profissional em nível federal e conselhos em nível regional. Esses conselhos são, em seu conjunto, "uma autarquia especial, dotada de personalidade 
jurídica de direito público, gozando cada um deles de autonomia administrativa e financeira" (França, 1994b: xviii). Cabe ao conselho federal da profissão votar qualquer alteração do Código de Ética.

Os conselhos regionais, por sua vez, têm as seguintes atribuições: 1) deliberar a respeito da inscrição dos profissionais legalmente habilitados;

2) manter um registro de profissionais numa determinada região; 3) fiscalizar o exercício profissional e impor as devidas penalidades; 4) velar pela preservação da dignidade e da independência do conselho; 5) apreciar e decidir sobre ética profissional, impondo as penas cabíveis; 6) proteger e contribuir para o perfeito desempenho técnico e moral da profissão; 7) exercer atos para os quais a lei lhe confere competência.

Cabe-lhes, ainda, elaborar proposta de regimento interno, expedir carteiras profissionais com valor legal de carteira de identidade, fiscalizar o exercício profissional de pessoa física e de pessoa jurídica de direito público ou privado, criar delegacias regionais e comissões de ética nos estabelecimentos de saúde públicos ou privados em sua jurisdição (no caso da medicina) e expedir normas ou resoluções para o pleno cumprimento do Código de Ética profissional (França, 1994b).

Os códigos de ética das profissões em saúde se estruturam, com poucas variantes, em: 1) deveres dos profissionais para com seus pacientes/ clientes e obrigações destes para com os profissionais; 2) deveres dos profissionais para com os seus pares e para com a profissão; 3) deveres da profissão para com o público e do público para com a profissão.

Como ressalva Spinsanti (1990), à medida que os interesses da corporação têm a possibilidade de se sobrepor aos interesses do coletivo, as normas deontológicas podem facilmente passar de meio para orientar a conduta dos médicos a meio para legitimar privilégios monopolizadores da profissão em relação ao Estado e ao público.

Vale ressaltar que os códigos de ética profissionais não se limitam apenas aos preceitos morais, mas dizem respeito a aspectos penais, civis e administrativos. Portanto, em geral, os códigos deontológicos tendem a refletir valores morais de uma sociedade em determinado período histórico. 
Dessa maneira, no âmbito da assistência materno-infantil, os preceitos deontológicos buscam garantir a saúde e a vida da mulher e do futuro nascituro. Tais preceitos estão inscritos nas legislações de nosso país e em declarações internacionais.

\section{Saúde Materno-lnfantil e as Obrigacões dos Profissionais da Saúde}

O conceito de saúde deve ser entendido além da simples ausência de doença, isto é, como resultante das adequadas condições de alimentação, habitação, saneamento, educação, renda, meio ambiente, trabalho, emprego, lazer, liberdade, acesso e posse da terra e acesso a serviços de saúde. Todos os códigos deontológicos das profissões em saúde no Brasil assumem o compromisso ético com 'a saúde e a dignidade do ser humano'.

O entendimento do conceito ampliado de saúde implica a superação e o redimensionamento da relação profissional de saúde-paciente/cliente. Ou seja, a responsabilidade do profissional da saúde não se limitaria ao 'corpo' do paciente/cliente, mas estaria engajado, também, na perspectiva de conquistas coletivas de melhores condições de vida para todos os brasileiros. Nesse sentido, o papel dos conselhos profissionais assume relevância na luta por melhores condições de assistência à nossa população, não ficando restrito à luta pela defesa da profissão isoladamente.

O desafio, no Brasil, de garantir a proteção e o desenvolvimento das crianças, consiste no dever primário de informar e dar apoio às famílias, para que estas estejam aptas a cuidar de suas crianças, e também de assegurar qualidade nos serviços públicos destinados a esse segmento da população.

Há 16 anos, foi aprovada uma nova Constituição Federal, na qual está previsto, no artigo 227, como dever da família, da sociedade e do Estado, tornar garantido à criança e ao adolescente, com prioridade absoluta, o direito à vida, à saúde, à alimentação, à educação, ao lazer, à profissionalização, à cultura, à dignidade, ao respeito, à liberdade e à convivência familiar e comunitária, além de colocá-los a salvo de toda 
forma de negligência, discriminação, exploração, violência, crueldade e opressão.

Em 1990, foi aprovado o ECA, através do qual crianças e adolescentes tiveram seus direitos garantidos em uma doutrina Sociojurídica de Proteção Integral, preconizada pela Organização das Nações Unidas (ONU) e tendo o Brasil como seu seguidor. O ECA, instituído pela Lei Federal n. 8.069/90, é um dos instrumentos fundamentais para a defesa e para o atendimento dos direitos dessa população.

O compromisso com o ECA é fazer com que suas normas legais sejam implementadas para que as crianças e os adolescentes possam, realmente, se tornar sujeitos do seu próprio destino, como preconiza nossa Constituição. Na prática, isso implica garantir o direito igual de todas as crianças a um nome e à nacionalidade, a uma boa alimentação, a bons serviços de saúde, à educação básica e à igualdade em sua condição de seres humanos.

Apesar de se constatar uma melhora significativa, nos últimos 15 anos, na situação de saúde das mulheres e das crianças do mundo, é verdade também que muito ainda pode ser feito pelo Estado, pela família e pela sociedade em geral para que se tornem efetivos os direitos das crianças, buscando dar-lhes uma vida digna e saudável (Unicef, 2001). É como afirma o artigo $4^{\circ}$, do ECA (2003):

É dever da família, da comunidade, da sociedade em geral e do Poder Público assegurar, com absoluta prioridade, a efetivação dos direitos referentes à vida, à saúde, à alimentação, à educação, ao esporte, ao lazer, à profissionalização, à cultura, à dignidade, ao respeito, à liberdade e à convivência familiar e comunitária.

A despeito de, nos últimos dez anos, o índice de mortalidade infantil ter manifestado uma tendência geral de declínio, ainda é alarmante o número de crianças que morrem no Brasil. A taxa de mortalidade infantil, em 1990, era de 47,8 mortes para cada mil crianças nascidas vivas. Em 1998, esta taxa caiu para 31,9 para cada mil (Unicef, 2001). Este índice é considerado como um indicador importante da qualidade de vida e das 
condições de saúde da população infantil, bem como do nível de desenvolvimento de uma população. Apesar da queda geral no índice, as regiões do Brasil apresentam diferentes taxas que expressam as desigualdades econômico-sociais existentes em nosso país.

A falta de acesso aos serviços de saúde e a precariedade desses serviços são fatores importantes que estão relacionados com as altas taxas de mortalidade infantil. Estima-se que 50\% das mortes de crianças com menos de um ano de idade aconteçam por causas perinatais (relacionadas ao parto e pós-parto). No entanto, segundo o Ministério da Saúde (MS), 11,9\% de óbitos infantis no Brasil são decorrentes de causas mal definidas. A falta de explicações médicas para estes óbitos é um indicador para avaliar a qualidade dos serviços materno-infantis oferecidos, pois revela falta de equipamentos nas unidades públicas de saúde e também carência de profissionais capacitados para verificação de óbitos e realização de diagnósticos.

As diferenças regionais quanto às causas de mortalidade, por sua vez, são bastante expressivas e refletem as desigualdades regionais. Em estados como Acre, Amazonas, Pará, Tocantins, e em toda a região Nordeste, causas mal definidas e não declaradas são as mais freqüentes nos atestados de óbito. Em alguns estados do Nordeste, como Maranhão, Paraíba e Sergipe, elas chegam a representar mais de 50\% dos óbitos. Provavelmente, estes óbitos estão associados à mortalidade infantil e a doenças infecciosas e parasitárias, ocorridas em localidades onde a oferta de serviços de saúde é ainda incipiente.

Um outro dado que deve chamar a atenção de todos os profissionais em saúde diz respeito ao número de crianças que nascem com baixo peso. Calcula-se que cerca de 270 mil bebês nascem, por ano, com baixo peso. Apesar do declínio em um terço da prevalência no retardo de crescimento na população infantil no geral, aproximadamente 20\% das crianças (menores de cinco anos) das áreas rurais apresentam disparidade entre a altura e a idade. As principais causas desses problemas estão relacionadas ao estado nutricional das mães e das crianças. O desenho adequado dos programas nutricionais, o aumento das atividades de 
supervisão desses programas e o envolvimento das comunidades na gestão dos mesmos poderão ajudar a melhorar seu desempenho. Esforços conjuntos devem ser envidados para a criação de meios adequados de educação alimentar e de acesso a alimentos em comunidades de baixa renda.

Tal perspectiva se torna relevante na medida em que boa parte das pesquisas sobre aporte nutricional revelam que a dieta da população de baixa renda no Brasil caracteriza-se por ser mais pobre em termos protéicos do que calóricos, gerando um descompasso entre a quantidade consumida e os nutrientes para uma alimentação adequada. Programas governamentais de aumento de renda desses segmentos da população e incremento de postos de trabalho podem ter impactos significativos nessa realidade social. No entanto, o papel dos profissionais da saúde nessa área ainda é crucial para a reversão dos índices de subnutrição que atingem, principalmente, a população infantil.

Em uma projeção para o futuro, Barros e Mendonça (1990) ressaltam que, ao se permitir que crianças nascidas em famílias pobres sejam afetadas de forma a comprometer seu desempenho econômico futuro, fecha-se o círculo da pobreza, isto é, as crianças pobres de hoje constituirão, com maior probabilidade, as unidades familiares pobres de amanhã.

Verifica-se que as crianças são o segmento da população mais atingido pelos efeitos da pobreza, que é a causadora de milhares de mortes que poderiam ser evitadas. Intimamente relacionados à pobreza estão as oportunidades de acesso aos serviços públicos de saúde, educação, saneamento, habitação e água. Apenas um terço dos domićlios pertencentes aos $40 \%$ mais pobres contam com o abastecimento adequado de água e esgotamento sanitário.

Outro desafio importante é a ampliação dos serviços de acompanhamento pré-natal e a melhoria da qualidade destes serviços. De acordo com o artigo $8^{\circ}$ do ECA (2003): "É assegurado à gestante, através do Sistema Único de Saúde, o pré-atendimento e perinatal". No ano de 1997, dos atuais 26 estados brasileiros e do Distrito Federal, somente dez (MG, SE, GO, MT, MS, PR, RJ, SP, ES e PB) alcançaram o índice de 50\% das mulheres grávidas que realizaram pelo menos as seis consultas pré-natais 
recomendadas. Esses dados representam um déficit de nove milhões de consultas a cada ano. Vale ressaltar que, mesmo nesses estados onde foi verificado esse índice, existem graves distorções dependendo do nível socioeconômico da população.

A precariedade nos serviços de acompanhamento contribui para uma das mais trágicas estatísticas brasileiras na área materno-infantil: a mortalidade materna. Segundo a Organização Mundial da Saúde (OMS), 99\% das 600 mil mortes maternas anuais ocorrem nos países do terceiro mundo, onde o risco é de 100 a 200 vezes maior do que nos países ricos. $\mathrm{O}$ Brasil ocupa a $65^{\mathrm{a}}$ posição no ranking mundial, com 140 mortes maternas/ 100 mil nascidos vivos. Se comparado com os Estados Unidos (9/100 mil) e Canadá (4/100 mil), o índice brasileiro se configura como um verdadeiro escândalo (Rosas, 2004).

Com efeito, só em 1998 foram registrados 2.051 óbitos de mulheres vítimas de complicações na gravidez, no parto e no pós-parto (Unicef, 2001). Segundo a Organização Pan-Americana da Saúde (Opas), calculase que 95\% das mortes maternas na América Latina seriam evitadas com os conhecimentos tecnológicos e médicos que temos atualmente e com medidas de impacto social. A melhoria desses serviços poderá reduzir esses números alarmantes, pois, na maioria dos casos, as mulheres morrem por causas facilmente detectáveis e com possibilidades de prevenção, como infecções e hipertensão arterial no período gestacional. A qualidade da assistência pré-natal e do parto depende não somente da instituição de saúde, mas também do profissional que presta atendimento.

Um outro fator que afeta a mortalidade na infância diz respeito à escolaridade da mãe. Pesquisas nesta área constataram que, se a mãe tem menos de um ano de estudo, a taxa é de 93 mortes para cada mil crianças nascidas vivas. Quando a mãe tem entre um e três anos de estudo, este índice cai para 70 por mil, e quando tem entre nove e 11 anos de estudo, a taxa média é de 28 por mil. Tais dados são relevantes tendo em vista que o nível de escolaridade da gestante/mãe representa um importante dado para a organização dos serviços de assistência materno-infantil. 
Um outro dado importante para a organização da assistência é o número de crianças e adolescentes que ficam grávidas. Segundo dados do Sistema Único de Saúde (SUS), são realizados por ano mais de 730 mil partos de meninas com idade entre 10 e 19 anos. Estudos nesta área vêm demonstrando que as adolescentes grávidas são mais pobres, têm nível de escolaridade mais baixo, menor atenção durante o pré-natal, filhos com maiores taxas de baixo peso ao nascer e maiores taxas de mortalidade neonatal e infantil (Simões et al., 2003; Gama, Szwarcwald \& Leal, 2002). Esforços tanto na prática de educação em saúde voltada para esse segmento populacional quanto numa assistência diferenciada no pré-natal e no parto devem ser envidados no sentido da prevenção de complicações e precoces óbitos.

Segundo pesquisa do MS, de 1999, as mães brasileiras amamentam seus filhos com leite materno por apenas 33,7 dias em média, embora o art. 90 do ECA (2003) assegure: "O Poder Público, as instituições e os empregadores propiciarão condições adequadas ao aleitamento materno, inclusive aos filhos de mães submetidas à medida privativa de liberdade". O aleitamento materno é um exemplo de política pública que envolve a família, a comunidade, os governantes e a sociedade civil, com baixo custo e excelente impacto sobre o desenvolvimento infantil.

Estima-se que, melhorando as práticas de amamentação em todo o mundo, as mortes de cerca de 1,5 milhão de crianças seriam evitadas todos os anos. Contudo, poucos dos 129 milhões de bebês que nascem todo ano recebem aleitamento materno exclusivo e alguns não são amamentados de forma alguma. O desmame precoce, o uso de suplementos desnecessários e a introdução de alimentos complementares antes da hora, infelizmente, ainda são práticas bastante comuns.

Com a implementação de programas simples, com o objetivo de informar às mães sobre os benefícios do aleitamento materno de preparar melhor os profissionais da saúde, pais e seus empregadores para dar condições e apoio às mães, pode-se aumentar o tempo de aleitamento dos bebês, trazendo impactos importantes para a saúde infantil.

De acordo com o art. $11^{\circ}$ do ECA (2003), "é assegurado atendimento médico à criança e ao adolescente, através do Sistema Único de Saúde, 
garantindo o acesso universal e igualitário às ações e serviços para promoção, proteção e recuperação da saúde". O Programa Saúde da Família (PSF), implementado pelo MS a partir de 1994, em parceria com o Fundo das Nações Unidas para a Infância (Unicef), tem sido uma estratégia para ampliar o acesso da população às ações básicas de saúde. O número de equipes de PSF cresceu de 328, em 1994, para 10.025 em setembro de 2000, quando o programa alcançou 3.059 municípios brasileiros. Tal estratégia vem pondo em questão não só a adequação da formação dos profissionais da saúde como também a própria organização dos serviços de referência para a assistência especializada.

Um outro indicador de dificuldade no acesso aos serviços de saúde está relacionado à falta de registro civil. Segundo dados de 1996, do MS, cerca de um milhão de crianças não foram registradas no primeiro ano de vida. O problema do sub-registro dificulta o acesso a serviços de saúde e de educação infantil e compromete o planejamento de prefeituras e estados, além de ser uma violação a um importante direito dessa população tão singular - "A criança tem direito, desde o seu nascimento, a um nome e a uma nacionalidade" - visto o Princípio III da Declaração dos Direitos da Criança, proclamada em 20 de novembro de 1959 pela Assembléia Geral das Nações Unidas, reafirmada na Convenção Sobre os Direitos da Criança, aprovado em 1989 pela Assembléia das Nações Unidas e ratificada pelo Brasil em 1990.

Segundo o relatório Situação da Infância Brasileira (SIB), feito pelo Unicef em 2001, uma das maiores conquistas do Brasil nos últimos anos foi o aumento nos índices de imunização contra coqueluche, difteria, tétano, sarampo, tuberculose e poliomielite. Esta vitória faz jus ao que é preconizado no art. 14º do ECA (2003): "É obrigatória a vacinação das crianças nos casos recomendados pelas autoridades sanitárias". Em 1994, foi concedido ao país, pela Opas, o certificado de erradicação da poliomielite. A imunização é um exemplo de intervenção, com custos relativamente baixos e com um enorme impacto no desenvolvimento infantil, que ajuda a assegurar o crescimento seguro da criança, deixando-a livre de doenças perigosas, mesmo quando vive em ambientes onde há risco para sua saúde. 


\section{CONClusões}

Vivemos em um país de graves desigualdades econômicas e sociais. Neste contexto, a ação dos serviços e dos profissionais da saúde assume extrema relevância. O compromisso ético de garantir uma assistência adequada e atenta às especificidades de nossa população materno-infantil é um imperativo para todas as categorias profissionais em saúde.

Os códigos de ética, as legislações específicas e os acordos internacionais impõem o dever ético e legal de proteção à saúde maternoinfantil. O arcabouço jurídico-institucional do SUS, que garante o controle social e o alcance de um nível de saúde e de dignidade de vida, só será possível com a participação ativa de toda a sociedade, para que seus direitos de fato sejam garantidos.

\section{REFERÊNCIAS BIBLIOGRÁFICAS}

BARROS, R. P. \& MENDONÇA, R. Infância e Sociedade no Brasil: as conseqüências da pobreza diferenciadas por gênero, faixa etária e região de residência. (Textos para discussão, n. 202) Rio de Janeiro: Ipea, 1990.

BOLETIM DO SYNDICATO MÉDICO BRASILEIRO. 8 ago. 1931. Disponível em: http://www.wplastia.com.br. Acesso em: 11 nov. 2003.

ESTATUTO DA CRIANÇA E DO ADOLESCENTE (ECA). In: CRESS $7^{\mathrm{a}} \mathrm{R}$. Assistente Social: ética e direitos - coletânea de leis e resoluções. Rio de Janeiro: 2003.

FERREIRA, A. B. H. Novo Aurélio. Versão eletrônica 3.0, 2003. CD-ROM

FRANÇA, G. V. Direito Médico. São Paulo: BYK, 1994a.

FRANÇA, G. V. Comentários ao Código de Ética Médica. Rio de Janeiro: Guanabara Koogan, 1994b.

FUNDO DAS NAÇÕES UNIDAS PARA A INFÂNCIA (UNICEF). Situação da Infância Brasileira (SIB), 2001. Disponível em: http://www.unicef.org/ brazil/sib2001. Acesso em: 9 dez. 2003. 
GAMA, S. G. N. da; SZWARCWALD, C. L. \& LEAL, M. C. Experiência de gravidez na adolescência, fatores associados e resultados perinatais entre puérperas de baixa renda. Cadernos de Saúde Pública, 18(1): 153$161,2002$.

GAZETA MÉDICA DA BAHIA, ano 2, n. 32-34, 1867.

KEYSERLINGK, E. W. Medical codes and oaths. In: CHADWICK, R. F. (Ed.) Encyclopedia of Applied Ethics. London: Academic Press, 1998. V. 3.

ROSAS, C. F. Mortalidade Materna - uma questão social: medidas para a redução da mortalidade materna. Disponível em: http://www.ipas.org.br/ arquivo/cristiao/mortalidade.doc. Acesso em: 10 mar. 2004.

SIMÕES, V. M. F. et al. Características da gravidez na adolescência em São Luiz, Maranhão. Revista de Saúde Pública, 37(5): 559-565, 2003.

SOUZA, A. T. Curso de História da Medicina: das origens aos fins do século XIV.

Lisboa: Fundação Calouste Gulbenkian, 1981.

SPINSANTI, S. Ética Biomédica. São Paulo: Paulinas, 1990.

\section{Sites relacionados à crianca e ao adolescente}

CONSELHO NACIONAL DOS DIREITOS DA CRIANÇA E DO

ADOLESCENTE - WWW.mp.sp.gov.br/caoinfancia.

DEPARTAMENTO DE INFORMÁTICA DO SUS (DATASUS)

-WWw.datasus.org.br.

DECLARAÇÃO DOS DIREITOS DA CRIANÇA adotada pela Assembléia da ONU em 20 de novembro de 1959

- www.direitoshumanos.usp.br/documentos/tratados/crianças/ declaracao_dos_direitos_da_crianca.html.

FUNDO DAS NAÇÕES UNIDAS PARA A INFÂNCIA (UNICEF)

- wWw.unicef.org.br/brazil

SIMPÓSIO INTERNACIONAL SOBRE A BIOÉTICA E OS DIREITOS DAS

CRIANÇAS (Declaração de Mônaco)

- www.ensp.fiocruz.br/etica/Arq/resout.htm. 


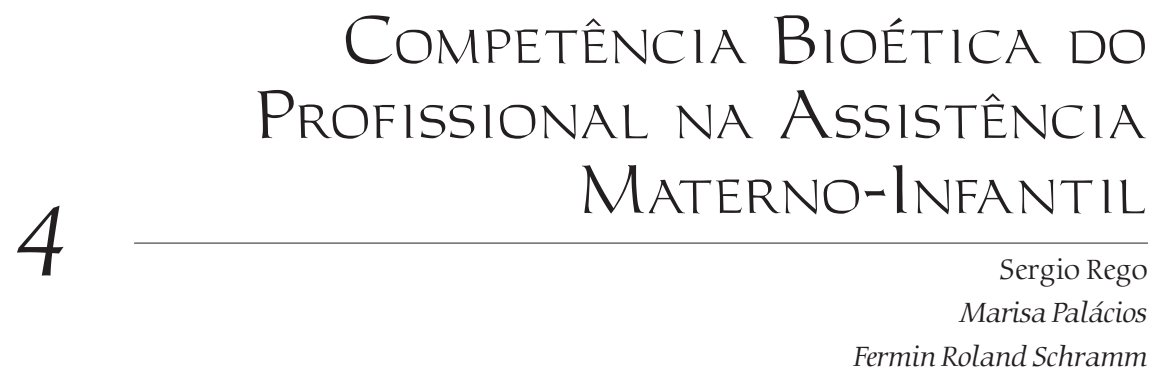

INTRODUCÃO

Neste texto, procura-se discutir de que forma é possível contribuir para o desenvolvimento da capacidade de os indivíduos realizarem julgamentos morais em princípio autônomos, considerando que tal tipo de julgamento é, em nossa maneira de ver, uma condição para considerar corretamente a situação dos possíveis conflitos que permeiam o campo da saúde materno-infantil.

Optou-se por uma abordagem essencialmente prática, embora respaldada pelos referenciais teóricos apropriados; ou seja, mais do que desenvolver novas concepções teóricas, optou-se por apontar de que forma as ferramentas da teoria podem ser utilizadas como referência para a organização de sua ação educativa. Assim, inicia-se discutindo, brevemente, as distinções entre os diferentes domínios (moral, convencional e pessoal), seguidos de um resumo das diferentes explicações sobre como um indivíduo adquire a capacidade de realizar um julgamento moral e, finalmente, analisa-se de que forma é possível utilizar as discussões de casos e/ou dinâmicas para o desenvolvimento da almejada competência.

\section{ENTENDENDO O DOMínIO MORAL}

É comum, quando se inicia uma discussão sobre moral e ética, haver uma dificuldade de identificar, ou reconhecer, qual determinado tema ou 
situação pertence ao campo da moral. Ou seja, o que é, afinal, uma questão do campo da moral? O que merece (ou é passível de) uma análise ética? O que significa moral e ética? Na verdade, existe uma razoável diversidade de compreensão desses conceitos e ela expressa os diferentes referenciais teóricos que podem ser legitimamente assumidos.

Resumidamente - por não ser este o objetivo principal desse artigo pode-se dizer que a moral refere-se aos conteúdos ('normas morais', 'princípios morais') e a ética, a aspectos formais e teóricos ('teorias éticas', 'métodos da ética'); que a moral refere-se às normas de conduta vigentes (intuitivas e 'vindas de fora' do indivíduo) e a ética, às normas de conduta resultantes do exercício da razão crítica; que a moral refere-se à dimensão subjetiva da conduta humana, à autodeterminação da vontade e à intencionalidade para o bem (características do caráter 'bom') e a ética, ao conjunto de normas e instituições (família, comunidade moral, sociedade civil, Estado) nas quais se realiza o ethos ('morada', costumes, hábitos) de um povo (características do 'bem-viver' institucionalizado).

Estas definições, entretanto, são insuficientes para ajudar a responder à primeira pergunta: como reconhecer se determinado comportamento ou acontecimento está inscrito no campo da moral? Inicialmente, é necessário reconhecer que nem todos os atos humanos pertencem ao campo da moral. E isso não somente porque - de acordo com uma antiga distinção feita por Aristóteles - existem atos humanos que são essencialmente poiéticos, isto é, que visam à construção de objetos (como fazer parafusos que apertem melhor, construir cadeiras para poder me sentar melhor, escrever poemas ou pensar em lógicas complexas para entender melhor porque estou vivo, ou projetar uma casa para poder viver melhor sozinho), mas, sobretudo, porque, em minha práxis (que, ao contrário da poiésis, envolve sempre outros seres vivos, em particular, humanos), existem atos que afetam de maneira significativa, ou não, os outros.

Isso nos leva a distinguir o que chamamos, aqui, 'ética' e 'etiqueta'. Ao se pensar na forma como se dirige, por exemplo, ao reitor de uma universidade - chamando-o de Magnífico Reitor -, está claro que não chamálo dessa forma não é um comportamento moralmente reprovável, na medida 
em que esta forma de tratamento é, na verdade, um costume que se caracteriza como uma convenção social. Tal convenção, particularmente, se inclui entre os padrões de comportamento classificáveis como de 'etiqueta'. Da mesma forma que chamar um enfermeiro de 'doutor', até alguns anos atrás, era um erro (convencional e não moral), mas hoje não o é mais.

Considere, agora, a roupa que você está usando neste momento. Ao escolhê-la (ou não escolhendo, mas pegando a primeira que viu no armário), estava ou não fazendo uma escolha moral? Se preferiu a camisa vermelha ou a amarela, se escolheu uma saia curta ou não, uma roupa branca ou colorida, você fez tais escolhas com base em suas preferências pessoais ou, também, em convenções sociais (no caso da cor branca para trabalhar ou na altura da saia). Essas escolhas não podem e não devem ser confundidas com escolhas morais, que pertencem não mais à mera 'etiqueta', mas sim à ética propriamente dita. Certo? Ou não?

Vale especular: considere a existência de uma seita religiosa que associe o vermelho à cor das entidades que representam o mal e que seu uso esteja, conseqüentemente, associado a provocar o 'mal'. Se você optar pelo uso de uma roupa dessa cor para comparecer a uma reunião com membros dessa seita, a sua escolha pessoal terá ou não uma dimensão moral? Estará contrariando uma mera convenção social ou provocando um dano moral?

Deve-se analisar estas questões com mais calma. Acredita-se que a maioria das pessoas aceita a idéia de que assassinar alguém é uma questão inscrita no campo da moral. Mas, e ao se pensar no ato de sacrificar um animal? Nesse caso, a maior parte das pessoas entende que matar um animal (como uma galinha) para alimentação não é uma questão moral. No entanto, existem aquelas que, sem pestanejar, afirmarão que não importa qual animal ou com que propósito: matar é sempre uma questão moral, pois implica eliminar um dos atores necessários para que exista uma questão moral, isto é, eliminar o outro - que pode ser um humano ou um ser vivo que possui determinadas características, como 'sentir dor' -, o qual deve existir para que uma questão moral se coloque e seja resolvida. 
Não havendo consenso a este respeito, surge outra hipótese. Pode-se supor que estão inscritos no campo da moral todos os atos possíveis de serem classificados utilizando-se a linguagem moral, isto é, aqueles que pertencem ao universo de objetos que fazem parte do campo da assim chamada análise conceitual dos fatos morais, a 'metaética'.

Agora, para que esta afirmação não se reduza a uma mera tautologia, deve-se responder à questão: o que é a linguagem moral? Esta questão refere-se à classificação entre bom ou mau, certo ou errado, justo ou injusto, deveres ou obrigações. Mas é claro que nem tudo capaz de ser classificado dessa forma pode ser referido ao campo da moral, já que nem todas estas duplas (bem/mal, correto/incorreto etc) referem-se exclusivamente ao domínio da moral. Para tanto, imagine a quantidade de atos corriqueiros que você pratica em seu cotidiano (como apontar um lápis ou conectar um aparelho eletrônico em uma tomada) e que podem ser classificados com algumas daquelas palavras referidas como pertencentes à linguagem moral e, nem por isso, seriam considerados como uma questão moral, visto que são atos essencialmente poiéticos. Assim, embora o uso da linguagem moral seja um caminho para a resposta, ela é insuficiente.

Ademais, passando do domínio das relações interpessoais para o das relações coletivas - que dizem respeito a um bem comum -, seria possível supor que pertença ao campo da moral tudo aquilo que uma determinada sociedade reconheça como tal para si própria (o que remete à relação da moral com a cultura - tema que não será abordado aqui). Mas, neste caso, existem dificuldades para se reconhecer, de forma irrefutável, o que seria este 'bem' compartilhado pelo senso comum - as quais já foram parcialmente demonstradas com o exemplo anterior sobre matar animais. Ou seja, este pode ser um caminho para se obter a resposta sobre o que é a moralidade, mas, de fato, é ainda insuficiente para que a resposta possa ser considerada satisfatória. Isso porque tanto para a relação 'eu-outro' quanto para a 'eu-socius' falta um denominador formal comum capaz de torná-las congruentes entre si e - o que é mais importante - abertas a novos atores que podem entrar no domínio da 
consideração moral, como podem, eventualmente, ser os animais 'sencientes' (que sentem dor e prazer) outros seres merecedores de nossa consideração.

Pode-se, então, tentar recorrer às doutrinas que procuram amparo nas chamadas 'regras de ouro' para tentar identificar o que está inscrito no campo da moral. De fato, estas ajudam a reconhecer formalmente possíveis fundamentos de ações, mas não esclarecem sobre o que estas ações ou julgamentos devem dizer respeito, isto é, sobre os conteúdos substantivos capazes de dar 'corpo' à forma. Por exemplo: pensando em 'imperativos categóricos' - que para Kant devem sempre ser respeitados -, que parecem ser, intuitivamente, os melhores representantes formais das 'regras de ouro', por que não incluir nesta reflexão o imperativo kantiano "[a]ge só, segundo uma máxima tal, que possas querer ao mesmo tempo que se torne lei universal" (Kant, s.d.: 70)?

Este imperativo moral, assim como cada uma dessas regras morais que pretendem ter uma validez, senão universal, pelo menos universalizável, não explicita em que temas específicos deve ser aplicado. Em outros termos, será que, se for aplicado a um tema como o tipo de penteado ou de corte dos cabelos, ele se aplica não só formalmente, mas também no nível dos conteúdos, isto é, substancialmente? Ou, ainda, será que o preceito muçulmano de cobrir os cabelos deve ser considerado em termos morais? Raspar os cabelos como os neonazistas, cobri-los como os sikhs ou trançálos como os rastafáris são questões morais? Em suma, esses conteúdos, certamente pertinentes para aqueles que pertencem a uma comunidade determinada existente, e que tiram dela as razões de seu agir, podem funcionar como 'regras de ouro' aceitáveis por aqueles sujeitos morais que não compartilham das premissas iniciais? Ou, dito em outros termos, será possível fazer com que os chamados 'estranhos morais' tornem-se 'amigos morais' (Engelhardt Jr., 1998) graças a algum referente formal supostamente universal, como poderia eventualmente ser uma 'regra de ouro'? Uma resposta simples a esta pergunta não é, evidentemente, possível.

Uma outra possível resposta à pergunta inicial pode ser dada por aqueles que dizem ser do campo da moral todo ato que possa afetar o bem- 
estar ou provocar o sofrimento de humanos ou de todos os seres sencientes, direta ou indiretamente, imediata ou tardiamente. Tal enunciado resolve uma série de problemas levantados pelas respostas anteriores, mesmo aquelas em que questões pessoais estão em jogo, como a da cor da roupa ou do que fazer com os cabelos. Resolve, igualmente, as questões relacionadas com as que incluem os animais ou o meio ambiente entre suas preocupações. Mas, mesmo assim, não é uma resposta que não tenha senões, já que não é passível de ser universalizável.

Considere, por exemplo, a situação de um pai guiando seu carro, indo para a praia com a esposa e os filhos. Imagine, também, que este pai esteja fumando. Embora não haja dúvidas de que o fumo cause danos à saúde de seus filhos, poucas pessoas afirmariam, intuitivamente, que este caso representa um problema de ordem moral. De fato, pode ser um comportamento socialmente reprovável, mas dificilmente, mesmo o mais ardoroso combatente do fumo iria dizer que esta questão pode ser percebida pela sociedade (ou pelo militante antitabagista 'comum') como uma questão moral.

Dizer que o que está no campo da moral é todo ato que possa afetar o bem-estar ou provocar o sofrimento de humanos ou de todos os seres sencientes (capazes de sentir dor), direta ou indiretamente, imediata ou tardiamente, é, de fato, uma definição mais apropriada do que as apresentadas anteriormente (por permitir uma melhor distinção com os campos convencionais e pessoais). Contudo, ainda assim, não é válida universalmente porque admite exceções.

Mas isso não é tudo. Resta ainda um problema a ser resolvido nesta abordagem inicial: por que as pessoas têm compreensões tão distintas sobre o que está ou não incluído no domínio da moral? Para responder, talvez indiretamente, a esta pergunta, seria interessante recordar uma situação descrita por Humberto Maturana (1998) em um de seus livros.

Conta ele que havia ido, com um grupo de amigos, visitar uma exposição sobre o holocausto nuclear, ocorrido no Japão no final da Segunda Guerra Mundial. Ao terminarem a visita, um de seus amigos comentou que não o incomodava que milhares de japoneses houvessem morrido naquele episódio, uma vez que ele não conhecia nenhum dos que morreram. 
Maturana conta que levou um susto com a afirmativa do amigo, mas que, depois, refletindo melhor, compreendeu o sentido da questão levantada. Para ele, se um indivíduo não inclui o outro como objeto de suas preocupações sobre as repercussões de seus atos, ele jamais terá uma questão ética em relação a esses acontecimentos, e isso independentemente do fato de outros (como ele antes de ouvir os argumentos do outro) considerarem este um 'fato moral'.

Traduzindo: para que se tenha uma questão ética, para que se inscreva essa questão no campo da moral, é preciso que você reconheça no outro alguém que mereça sua preocupação. Assim, parece mais fácil entender este quadro tão diverso: existem pessoas que estão apenas preocupadas, pelo menos aparentemente, consigo próprias; outras que incluem seus familiares; outras, seus concidadãos; outras, a humanidade inteira; outras, os seres sencientes; outras, a biosfera; e outras, o universo inteiro, preocupando-se, por exemplo, com as conseqüências do lixo espacial para o equilíbrio do universo, rejeitando a idéia de utilizar o espaço como depósito de lixo nuclear. Como as pessoas e as diferentes sociedades refletem de forma desigual esta percepção e inclusão, Maturana defende a importância dos pactos mundiais de reconhecimento do outro, como é o caso, por exemplo, do pacto que deu origem à Declaração Universal dos Direitos do Homem ou, mais recentemente, o do Genoma Humano.

Mas incluir o outro como objeto de suas preocupações quanto à repercussão de seus atos ainda não explica o ato moral. O que seria, então, um ato moralmente significativo?

Imagine, agora, um ato que você considere moralmente significativo. Talvez o que tenha pensado seja, de alguma forma, semelhante ao que será descrito a seguir. Imagine uma situação em que uma pessoa esteja andando numa rua e vê, a uns 20 metros à sua frente, uma mulher distraída, falando ao celular parada. Quando esta pessoa pára e se vira para atravessar a rua, vê, também a uns 20 metros, um homem com um revólver que se prepara para atirar na direção da mulher. A pessoa de nossa história, horrorizada com a cena, dá um passo adiante e grita "- Não atire!", no exato momento em que o homem atira e acaba atingindo-a no braço. 
Embora tenha ficado ferida, o seu ato de gritar salvou a mulher que falava ao telefone.

Você possivelmente concorda que esta atitude pode ser considerada como um ato moralmente relevante, não? Pois então imagine a mesma cena, mas com a pessoa que caminha não percebendo o atirador e se abaixando para amarrar os sapatos no exato momento em que o tiro é disparado. Ela igualmente recebe o tiro no braço, salva a vida da mulher, mas... será que este ato também pode ser considerado moralmente relevante? Provavelmente você acha que não - este ato não é comparável ao outro, apesar de o resultado ter sido semelhante. Agora, numa avaliação moral, a diferença significativa é que em um deles ocorreu um ato motivado por uma decisão pessoal e, no outro, a mesma conseqüência foi resultado de um ato fortuito, acidental (Nucci, 2001).

Alguém poderia argumentar que, na verdade, aquele ato não foi provocado pelo uso da razão, mas sim por uma reação tipicamente instintual ou emocional. Há muito que poderia ser dito sobre a emoção e a tomada de decisão ética, mas esta discussão extrapolaria os limites a que este artigo pretende se ater. É importante lembrar apenas que, segundo Kilcullen (1996), para Adam Smith o sentimento moral é base suficiente para o julgamento moral, entendendo sentimento no sentido de emoção, isto é, de um eu sentir 'algo' e de eu sentir algo para (com) 'alguém'. Compreensão aparentemente semelhante a que tinha David Hume, filósofo escocês que também viveu no século XVIII e que afirmou: "as avaliações morais envolvem nossas emoções e não nossa razão" (Hume apud Fieser, 2003). Para ele, as pessoas podem acumular todas as razões que querem, mas, sozinhas, elas não resultarão em uma única avaliação moral. Em suma, necessita-se de uma reação especificamente emocional para fazer um pronunciamento moral. Em outros termos, a razão poderia ser de alguma utilidade ao fornecer os dados relevantes, mas, nas palavras de Hume, "a razão é, e deve ser, a escrava das paixões" (apud Fieser, 2003).

Já o filósofo alemão Immanuel Kant (s.d.), embora reconhecesse que os fatores emocionais usualmente influenciam nossa conduta (o que ele tinha, reconhecidamente, aprendido com Hume), afirmou sobre a necessidade 
de resistir a tais fatores. Segundo ele, a verdadeira ação moral é aquela motivada apenas pela razão, quando ela estiver livre de emoções e desejos.

É interessante assinalar, no entanto, que parece difícil aceitar a possibilidade da existência de uma ação moral sem que esta envolva algum componente emocional, até porque este é um componente talvez necessário para que exista uma relação entre um 'eu' e um 'outro'. Todavia, entendese também que isso não é 'suficiente': embora os sentimentos e as emoções devam ser levados em consideração, não se pode deixar que as paixões ou os vícios configurem os atos das pessoas de forma independente - sem alguma instância capaz de conformá-los de acordo com uma maneira que os torne inteligíveis para além do sentir individual e, eventualmente, da mera relação emocional interindividual - para que o 'emocionar-se' tornese inteligível por todos aqueles envolvidos diretamente na situação. Em outros termos, os homens também são seres racionais, capazes de usar o raciocínio - e devem usá-lo, inclusive para analisar as emoções; sobretudo para entender o emocionar-se dos outros, relação da qual podem, provisoriamente, estar excluídos. Emoções estas que, respeitadas determinadas condições, podem ser resultantes da análise racional. Como afirmaram Cohen e Segre (1994):

Muitos crêem que a eticidade, ou condição de vir a ser ético, significa apenas a competência para ouvir o que o coração diz. Acreditamos que essa seja apenas uma característica de sensibilidade emocional, reservando-se o ser ético para os que tiveram a capacidade de percepção dos conflitos entre o que o coração diz e o que a cabeça pensa, podendo-se percorrer o caminho entre a emoção e a razão posicionando-se na parte desse percurso que se considere mais adequada.

Retomando, portanto, a discussão original, deve-se assinalar que o fato de alguém responder, de forma automática, ao valor resultante de uma soma de dois mais dois, não significa que sua resposta não tenha sido um resultado de seu pensamento. Da mesma forma, a decisão de interferir na situação descrita, tentando impedir que a mulher fosse baleada, também é resultado do raciocínio. 


\section{Desenvolvimento da Capacidade de Realizar Julgamentos Morais}

Entendendo, assim, que a realização de julgamentos morais é uma atividade cognitiva, resta perguntar como um indivíduo adquire esta capacidade. Existirá alguma relação entre o desenvolvimento intelectual e a capacidade de julgar? Qual a importância que uma autoridade constituída exerce no processo de julgamento moral? O que significa tomar uma decisão autonomamente? Qual a influência que os pais, os professores e a sociedade em geral têm no desenvolvimento da capacidade de um indivíduo em realizar julgamentos morais? E, finalmente, após ter atingido a idade adulta, ainda é possível algum tipo de mudança nos padrões ou tipos de julgamentos que fundamentam as tomadas de decisões dos indivíduos em termos morais?

As respostas a essas questões variam, prevalentemente, de acordo com a afiliação teórica de quem esteja respondendo. As correntes teóricas mais significativas são as teorias psicanalíticas, as teorias da aprendizagem social e as teorias do desenvolvimento sociomoral cognitivo (Rego, 2003). Cada uma dessas diferentes abordagens teóricas contribui para a compreensão desse processo, não sendo possível desprezar qualquer uma para o seu efetivo entendimento. Por isso será apresentada uma brevíssima síntese dos fundamentos das correntes principais, com ênfase na abordagem cognitivista que, em nosso entendimento, oferece, a partir dos estudos de Jean Piaget (1993, 1994, 1996), a explicação mais consistente e completa, embora não excludente.

Para a abordagem psicanalítica freudiana, a consciência moral é a manifestação do superego, que age avaliando ou censurando o ego. O superego é formado pelo distanciamento do ego, resultante da interiorização de forças repressivas que o indivíduo encontrou durante seu desenvolvimento, "pela identificação bem-sucedida com a instância parental" (Laplanche \& Pontalis, 1992: 499). Segundo estes autores, a referência à 'instância parental' significa que não está sendo feita uma referência à identificação com pessoas ou, como referem, "o superego da criança não se forma à imagem dos pais, mas sim à imagem do superego deles; enche-se do mesmo 
conteúdo, torna-se o representante da tradição, de todos os juízos de valor que subsistem assim através das gerações" (Laplanche \& Pontalis, 1992: 499). Outros autores, como Bourdieu (1996), explicarão a reprodução de valores através da educação, utilizando-se, por exemplo, de seu conceito de habitus.

As raízes das teorias da aprendizagem social estão fundamentadas no empirismo de John Locke, que comparava a mente de um indivíduo a uma tábula rasa, na qual se registram os estímulos do meio que, por sua vez, determinam suas respostas comportamentais (Rosa, 1996). Para esta corrente, é considerado 'estímulo', no âmbito do comportamentismo ou behaviorismo, qualquer evento que atua sobre um organismo, e 'resposta', qualquer comportamento produzido por aquele organismo. $\mathrm{O}$ 'condicionamento' seria a base do aprendizado e pode ser de três tipos: 1) o clássico, tipicamente pavloviano, configurando-se no modelo de respostas incondicionais (modelo estímulo-estímulo); 2) o 'operante', também chamado de instrumental (modelo estímulo-resposta), pelo fato de a resposta servir como instrumento para a obtenção do reforço; 3) o por 'imitação' de modelos.

Para essas teorias, são fundamentais os conceitos de reforço positivo (onde existe maior possibilidade de se obter uma repetição do evento), reforço negativo (que, quando suprimido, aumenta a probabilidade de o evento se repetir) e punição (a ação que diminui a chance de um determinado evento ocorrer ou se repetir).

O psicólogo canadense Albert Bandura, que trabalha na Universidade de Stanford, promoveu com seus estudos a maior mudança nesta teoria. Incorporando a ela elementos cognitivistas, ampliou sua aceitação nos meios acadêmicos e terapêuticos, desenvolvendo sobremaneira os processos terapêuticos de fobias, por exemplo. Bandura introduziu os conceitos de sistema auto-regulatório e de auto-eficácia, enfatizando a importância do reforço positivo para a repetição dos eventos e apontando para a possibilidade de existir um diferencial de tempo entre estímulos e respostas. As mudanças foram tão acentuadas que Bandura passou a chamar sua teoria de teoria cognitiva social. Seus principais méritos estão nas explicações 
sobre os comportamentos assumidos. Ela tem sido muito usada na discussão sobre a relação entre televisão e violência, a qual destaca que a repetição de exemplos de comportamentos socialmente indesejáveis tratados como aceitáveis, ou vitoriosos, na televisão ou no cinema, poderia reforçar o comportamento anti-social (Biaggio, 1975).

Por fim, há as teorias cognitivistas do desenvolvimento sociomoral, que têm suas origens na filosofia de Immanuel Kant e nos estudos empíricos e na teoria de Jean Piaget (1996). Este último estava interessado, inicialmente, em estudar a gênese e a evolução do pensamento humano, e entendeu que poderia compreender este tema se estudasse de que forma as crianças constroem as noções fundamentais de conhecimento lógico, tais como tempo, espaço, objeto e causalidade. Sua teoria é composta por conceitos como o de 'estrutura', que é a forma de organização (física ou abstrata) responsável pelas ações do indivíduo. A partir daí, então, é que resultaria uma autêntica co-construção do sujeito cognitivo e do mundo conhecido, construção feita pelo sujeito epistêmico em sua interação com este mundo, de acordo com as estruturas biológicas, mentais, psicológicas ou cognitivas da própria autoformação do indivíduo em seus embates com o contexto no qual atua e pensa.

Em outros termos, uma estrutura psicológica é composta por um 'esquema' integrado (ou até mais de um), que, por sua vez, é considerado a unidade estrutural básica do pensamento. Um esquema pode ser constituído desde uma seqüência específica de atividades motoras que são usadas - como abrir uma garrafa de vinho - até estratégias mentais utilizadas para a solução de problemas abstratos, como resolver uma equação matemática complexa. Em suma, no entender de Piaget, a criança busca organizar suas estruturas cognitivas em um sistema que possibilite a ela adaptar-se à realidade e, também, integrar a realidade às suas estruturas cognitivas, em um processo chamado 'equilibração'.

O desenvolvimento, portanto, é entendido como um processo que busca atingir equilíbrios cada vez melhores por meio da interação com o ambiente (físico e social). A todo momento, as crianças (e, por que não dizer, as pessoas) são solicitadas a solucionar problemas novos. Esta 
demanda, provocada por novos desafios, leva a um desequilíbrio que resultará em uma maneira mais eficiente de lidar com o ambiente. Como resultado de suas pesquisas empíricas, Piaget (1996) observou que existem diversos padrões de interação com o ambiente e na forma de pensar e agir nas diferentes faixas etárias. Assim, identificou o que ele chamou de 'estágios do desenvolvimento cognitivo', embora reconhecesse que as faixas etárias desses estágios eram mais variáveis do que se poderia afirmar peremptoriamente. Em suma, os estágios são integrativos, ou seja, somam os novos esquemas e estruturas aos que já existiam no estágio anterior.

A partir de seus estudos sobre o desenvolvimento cognitivo, Piaget passou a se perguntar sobre de que maneira as pessoas realizam julgamentos morais. Para tal, estudou a forma como as crianças se comportam durante jogos, em relação ao entendimento das regras e ao respeito a elas. Observou que havia alguma similaridade com o processo que ele havia identificado para o desenvolvimento cognitivo. Notou, igualmente, que as crianças evoluíam de um respeito absoluto à autoridade externa a um processo de progressiva autonomia na realização dos julgamentos, sendo que a autonomia, para Piaget, se refere à liberdade do constrangimento causado pela heteronomia (ausência de autonomia).

Para ele, toda moral se desenvolve no respeito que o sujeito nutre a favor das regras: não se trata de simplesmente aceitar as regras como uma força externa ao indivíduo (comportamento heterônomo), mas de aceitálas como a melhor opção. Imagine um sinal de trânsito. Por que você não avança o sinal? Será que é porque existe um radar e você pode ser multado? Ou porque a lei não permite e ninguém é livre para ir contra ela? Ou seria porque você entende que se todos fizerem o mesmo seria impossível andar de carro na cidade e, portanto, a lei é boa, e você deseja cumpri-la para o maior interesse da sociedade e, por conseguinte, seu próprio? Existem diferentes razões que podem motivar alguém a desrespeitar ou não um sinal de trânsito e, de acordo com a teoria piagetiana, elas podem ser em decorrência de uma razão interna ou externa à pessoa. Para essa abordagem teórica, quanto mais heterônomo, menos desenvolvidas são as estruturas mentais do indivíduo. 
O psicólogo norte-americano Lawrence Kohlberg avançou nos estudos de Piaget ao incluir, nas populações estudadas, adolescentes e adultos jovens, identificando, assim, uma seqüência de seis estágios de desenvolvimento moral cognitivo que evoluem da motivação heterônoma da decisão para a fundamentação autônoma e dos interesses egoístas aos interesses da sociedade, baseados em princípios éticos na fundamentação das decisões.

Diversos autores têm dado continuidade aos estudos empíricos de Piaget e Kohlberg, revendo alguns pontos teóricos que não serão apresentados aqui. ${ }^{1}$ No momento, é suficiente citar, por exemplo, que Carol Gilligan (1998) apontou - com propriedade - um certo viés de gênero no arcabouço teórico, devido, especialmente, a problemas de método nos trabalhos empíricos, consistentes em enfocar, preferencialmente, formas de pensar que, supostamente, privilegiariam determinadas maneiras de considerar a relação com o mundo (essencialmente 'masculinas') em detrimento de outras (essencialmente 'femininas').

Elliot Turiel (2002) destacou-se entre os novos teóricos quando apontou as diferenças existentes nos domínios moral, social e pessoal (abordados no início desse artigo) e ao enfatizar a importância de ser considerado de forma particular o meio ambiente dos indivíduos, tanto quando forem pesquisados como quando estiverem sendo programadas ações educativas.

Com base nas concepções teóricas desenvolvidas por Turiel, entendese que é indispensável que se atente para uma contextualização adequada das situações que serão usadas em pesquisas ou em atividades educacionais. Nesse sentido, é fundamental que sejam usados problemas particularmente conflitivos ou mesmo os chamados dilemas (que são aqueles que, em princípio, são sem solução a priori), capazes de provocar o desequilíbrio cognitivo anteriormente mencionado, propiciando, assim, que o indivíduo busque nova adaptação, evoluindo na construção de suas estruturas responsáveis pelo julgamento moral.

Embora possa haver alguma utilidade - como é exposto na próxima seção - no uso de situações dilemáticas clássicas ou prototípicas, o mais 
eficaz deve ser o uso de situações nas quais os indivíduos sejam capazes de se envolver mais completamente, até emocionalmente. Um dilema sobre 'suborno de autoridades estrangeiras para obtenção de vantagens na legalização de empresas', apresentado a estudantes de medicina ou de enfermagem, terá uma possibilidade remota de mobilizá-los.

De fato, o indivíduo, para poder refletir corretamente, deverá enfocar um conflito, ou um dilema, diretamente relacionado com o tipo de trabalho em que atua. Adiante, procura-se desvendar de que forma é possível interferir no desenvolvimento da competência moral de adultos, no caso adotado para reflexão: médicos e enfermeiros.

\section{DESENVOLVIMENTO DA COMPETÊNClA eM BIOÉTICA²}

A maioria dos não-especialistas no tema, quando pensa em educação moral, possui uma compreensão bastante distorcida do que trata este assunto. A maior parte deles ainda traz na memória as recordações, por vezes terríveis, das suas experiências de catecismo, da antiga disciplina educação moral e cívica ou mesmo religião, ou ainda, da disciplina de ética deontológica nos cursos de graduação. Essas recordações são, quase que invariavelmente, de pessoas apresentando a eles uma série de comportamentos desejáveis ou os quais a sociedade esperaria deles. São comportamentos virtuosos, sem dúvida, mas esse modelo 'educativo' - com base na transmissão unilateral de um saber - é criticado até mesmo para o ensino da matemática e, ainda mais, para qualquer tipo de educação moral que aponte para a formação de indivíduos mais autônomos.

Esta é a questão central no modelo de ensino: o objetivo é apenas informar uma série de conteúdos a dóceis aprendizes ou espera-se estar contribuindo, de forma efetiva, na mudança de comportamentos que levem os indivíduos a se tornarem cada vez mais senhores de suas próprias razões, compartilháveis com qualquer outro ser racional e razoável? E o que as pessoas interessadas em Bioética têm a ver com isso, particularmente quando se pensa em profissionais já formados e em plena atividade profissional? 
O que tem sido defendido nos mais diversos fóruns é que a educação moral deve tornar-se uma preocupação permanente para todos os que estejam envolvidos em atividades educacionais ou mesmo para aqueles que acreditam na possibilidade de deixar um mundo melhor para as próximas gerações. Neste caso específico - nos limites propostos para este texto -, a educação moral deve ser vista como uma obrigação daqueles que coordenam programas de pós-graduação na modalidade de residência ou mesmo para aqueles que apenas participam do programa como preceptores ou docentes.

O compromisso com a preparação de profissionais da saúde não pode, sob pena de comprometer sua excelência, limitar-se aos aspectos técnicos do exercício profissional. Não se pode repetir na pós-graduação os erros que vêm sendo cometidos nas graduações, que é o de acreditar que o bom senso pessoal irá prevalecer ou que exista uma benevolência natural entre os homens. Mas como entender esse 'bom senso'?

Tem-se encontrado diversas referências ao bom senso, mas sem definições satisfatórias. Será que o bom senso pode ser considerado teoricamente da mesma forma como Freud tratou o conceito de consciência psicológica, segundo Laplanche e Pontalis (1992)? Isto é, como "um fato sem equivalente que nem se pode explicar nem se pode descrever" e que, no entanto, "quando se fala de consciência, todos sabem imediatamente, por experiência, do que se trata" (Freud apud Laplanche \& Pontalis, 1992: 93).

Tal abordagem não parece ser a mais adequada e, portanto, é preciso que se faça uma tentativa de conceituação do termo bom senso: este pode ser definido como uma espécie de guia pessoal que orienta a ação do indivíduo no sentido da pretensa manutenção do bem-estar da sociedade ou - em uma outra tentativa de conceituá-lo - pode ser entendido como um guia pessoal para que o indivíduo o perceba como sendo a moral dominante ou a moral que ele deseja que seja a dominante. Por lidar com dimensões subjetivas e imprecisas, o bom senso não pode ser o único parâmetro-guia para a tomada de decisões no campo da ética, campo em que se considera, necessariamente, a repercussão de ações no bem-estar de todos os seres sencientes. 
Com freqüência, são feitas referências às dificuldades que os cursos de graduação têm enfrentado para introduzir disciplinas ou conteúdos de Bioética em seus programas. Essas dificuldades são bastante semelhantes quando se pensa nos programas de pós-graduação e, particularmente, nos programas de residência médica que - seguindo as diretrizes da Comissão Nacional de Residência Médica - devem obrigatoriamente introduzir esses conteúdos em seu programa. Mas quais são eles?

A primeira dificuldade está na percepção da relevância desta formação específica por parte de docentes, alunos e encarregados do planejamento educacional ou das atividades. Estudantes em qualquer nível de sua formação desejam se dedicar a atividades e conteúdos que venham a ser significativos para o seu futuro profissional; existe uma percepção - a qual não se sabe se é majoritária ou não - de que o importante é o conhecimento técnico e de que discussões éticas, ou sobre aspectos psicológicos de pacientes, são supérfluas.

Para a maioria dos médicos representados na pesquisa "Perfil dos Médicos no Brasil" (Machado, 1996), ser ético no exercício profissional significa tão-somente seguir o Código de Ética (embora cerca de 10\% dos médicos, na época, confessaram nunca o ter lido). Isso significa que é indispensável um trabalho de sensibilização dos profissionais da saúde para que entendam que o exercício ético de uma profissão não pode ser compreendido como mero cumprimento acrítico de um código. Este comportamento nega a potencialidade do indivíduo, como agente moral autônomo, de realizar seus próprios juízos e de tomar suas decisões de forma consciente. Até porque os códigos de ética não possuem respostas para tudo, visto que um código, por definição, só pode referir-se, na melhor das hipóteses, a uma casuística já pensada, ordenada e sistematizada, que, por isso mesmo, só pode referir-se a algo que já passou. Em suma, as diretrizes prescritivas dos códigos não ajudam alguém a tomar decisões na complexidade e diversidade da vida e do exercício profissional, nas quais, inevitavelmente, encontra situações inéditas.

Mas, supondo que não houvesse problemas de motivação para a incorporação plena da temática e dos métodos da Bioética nos currículos 
dos cursos de graduação e de pós-graduação, isso não significaria o fim dos problemas, mas apenas uma mudança de tipos. Deve-se considerar, ainda, as questões relacionadas à docência, incluindo os problemas com docentes, método de ensino e conteúdos.

Os problemas de conteúdos podem ser vistos como uma estratégia para se abordar os demais. O que incluir em um programa? A primeira dificuldade está na percepção sobre o que seja Bioética por parte da comunidade de não-especialistas no tema. Como demonstrou Rego (2001), os documentos que compõem as Diretrizes Curriculares para os cursos de graduação na área da saúde, elaborados por parte da elite acadêmica do país, confundem Bioética com o principialismo. Ou seja, identificam o todo pela parte. ${ }^{3}$

De uma outra forma, o fenômeno do desconhecimento sobre a Bioética também pode ser observado ao se considerar alguns dos conteúdos de disciplinas de Bioética que têm surgido em diversas faculdades. Eles apresentam, quase exclusivamente, conteúdos deontológicos! Há dúvidas se são apenas equívocos de pessoas bem-intencionadas ou se existe, efetivamente, uma má fé por parte de escolas e/ou docentes, que apresentam esses conteúdos com uma nova roupagem para que assim pareçam estar atualizados. Um exemplo disso aconteceu com estudantes de uma faculdade carioca. Eles receberam um exemplar que lhes foi apresentado como um Manual de Bioética, o qual teria o objetivo de orientá-los sobre como agir. Depois foi constatado que o referido 'manual' era, na verdade, o Código de Ética Médica!

Ultrapassado o mero reconhecimento sobre o que é a Bioética, existem outras limitações significativas, como o conhecimento efetivo do campo. Ainda que consiga reconhecer o que está no campo, uma significativa proporção dos profissionais que já se dedica à Bioética no Brasil ainda não possui uma formação específica nos conteúdos filosóficos e nos métodos da Bioética. Este é um limitante que compromete a qualidade da prática. É importante assinalar que não está sendo defendida aqui a necessidade da formação em nível de graduação ou pós-graduação em filosofia para atuar na área, mas sim que haja uma dedicação ao estudo do campo. 
De fato, a Bioética não é um 'campo do bom senso', mas um ramo da filosofia ou, mais especificamente, da filosofia moral aplicada, com suas ferramentas teóricas e práticas específicas que podem, eventualmente, ser construídas e compartilhadas com outros saberes do campo das ciências humanas e sociais e, talvez, das ciências naturais, razão pela qual muitos autores considerem, pertinentemente, a Bioética como um campo interdisciplinar e até transdisciplinar. E é neste segundo sentido que ela precisa ser considerada, pois somente assim pode exercer seu papel crítico, inclusive no sentido de crítica do senso comum e de especialização entendida como saber constituído que não se questiona incessantemente sobre sua ignorância frente ao mundo da vida que se faz e se desfaz.

Em outros termos, não é possível existir a disciplina 'Bioética' sem que sejam contempladas as diferentes correntes teóricas, assim como seus diferentes métodos e seus referentes da vida de relação. É claro que existe uma outra possibilidade consistente em adotar uma perspectiva particular. Algo como um curso de Bioética principialista ou utilitarista, por exemplo. Mas as opções devem ser conscientes, explicitadas e sérias do ponto de vista acadêmico; ou seja, deixando claro qual é a opção teórica adotada e, sobretudo, que esta é somente uma das opções possíveis. Isso implica que se deva escolher 'sua turma'.

Kottow (2002), por exemplo, assume a questão dos conteúdos como a de maior significância. Justifica a necessidade de fortalecer um discurso que dê fundamento a uma dinâmica docente reflexiva da Bioética, fundamentalmente por seis circunstâncias em que a medicina é exercida na América Latina: 1) dependência econômica dos serviços médicos; 2) sofisticação da medicina; 3) erosão dos limites entre saúde e doença; 4) erosão da diferença entre necessidade e desejo; 5) ênfase na medicina preventiva e pública; 6) a situação específica da América Latina.

Superada, nestas breves considerações, a questão do tema, surge a inevitável questão sobre como ensinar, que foi abordada rapidamente no início dessa seção. Houve um tempo, não muito distante no Brasil, em que o ensino da ética estava reservado aos docentes de moral ilibada, capazes de realizar preleções e conferências doutrinárias, talvez por se acreditar 
que conhecer virtudes desejáveis fosse o suficiente para que os indivíduos as adotassem como regra em seu agir ou por se entender que as pessoas serão virtuosas porque assim requer a sua prática profissional ou os seus professores. Mas estas são compreensões típicas dos que são incapazes de distinguir vontade de saber, entendendo que bastaria conhecer a virtude para ser virtuoso, conhecer a justiça para ser justo...

Se uma atividade educativa sobre ética não pode se limitar a um discurso sobre virtudes, muito menos deve ser limitada à discussão de casos, por mais ricos que possam ser. É necessário que também seja dado aos indivíduos acesso à caixa de ferramentas da disciplina. Os casos serão indispensáveis para a construção da competência em Bioética, mas devem também ser escolhidos com o propósito de desenvolver a competência moral, propriamente dita. Distingue-se, aqui, a competência em Bioética da competência moral, uma vez que um indivíduo pode ser competente no uso da caixa de ferramentas da Bioética e, no entanto, incompetente na realização de julgamentos morais autônomos, por razões que chamaremos, sem mais, de idiossincráticas. Assim, a competência moral está diretamente associada à capacidade de o indivíduo realizar julgamentos morais de forma autônoma e, também, de se comprometer na defesa de seus princípios.

Em uma certa ocasião, foi publicada uma charge em uma revista de Bioética que chamou muito a atenção: havia um balcão e, nas prateleiras atrás deste, estavam colocadas diversas estatuetas como se fossem indivíduos, cada um segurando um pequeno cartaz com sua identificação de acordo com uma suposta linha de pensamento - utilitarista, conseqüencialista, principialista, católico, judaico, deontológico etc. Do lado de fora do balcão, um cliente é atendido pelo balconista que lhe oferece: "que opinião o senhor deseja para o seu caso?".

A discussão de casos não se dá através do confronto de idéias ou argumentos do professor com os seus estudantes. O papel do professor não é, e não pode ser, o de incutir nos alunos o seu sistema de valores ou suas crenças. O papel do professor é o de provocar conflitos cognitivos em seus estudantes. É o de estimular que eles se questionem sobre seus valores, isto é, o de questionar o senso comum. É o de surpreendê-los com teses 
que contradizem o senso comum ou o 'politicamente correto'. É este constante desafio intelectual que é a principal função do professor, e não o repasse de teorias ou valores.

Para tal, é fundamental que o docente respeite o processo de construção da autonomia do estudante. É indispensável que o professor compreenda que a sua opinião sobre determinado assunto não terá de prevalecer ao final de uma discussão. O professor tem de respeitar o outro. Se as convicções de um indivíduo sobre determinado tema são tão fortes para ele a ponto de não conseguir aceitar que alguém tenha uma posição diferente, a sugestão é: não seja um professor! O professor não está ali em situações de igualdade com o estudante e, portanto, não pode ser equiparado a ele quanto à liberdade argumentativa. O estudante pode até tentar desqualificar o argumento do professor e este deverá demonstrar ao estudante que este subterfúgio em um debate é típico dos que não têm argumentos, mas jamais o professor poderá fazer o mesmo!

Antes da conclusão, é interessante tratar brevemente da questão religiosa. Como a sociedade brasileira atual se pretende democrática e laica, e isso apesar das contingências mundiais de um 'retorno do recalcado' que se manifesta, aqui e acolá, no mundo atual de conflitos entre 'fundamentalismos' (econômicos ou religiosos que sejam), defende-se a idéia que toda política pública seja balizada no reconhecimento do caráter laico do Estado. Isto significa que toda decisão que afete apenas a vida de um indivíduo pode ser fundamentada com argumentos religiosos, mas estes argumentos nunca devem ser válidos quando o que está em jogo é uma parcela da sociedade ou, especificamente, a sociedade inteira.

Assim, o professor não pode jamais permitir que suas conviç̧ões religiosas (ou a falta delas) sejam impeditivas do reconhecimento do direito do outro fundamentar suas opiniões de forma diferente. O que não quer dizer que se deva, por exemplo, apenas aceitar verdades de fé sem as questionar. É função do professor questionar argumentos para possibilitar que os indivíduos - os alunos - desenvolvam sua capacidade de refletir eticamente, mas o docente não poderá jamais humilhar ou ofender de qualquer forma o outro devido às suas convicções. Em uma certa medida, 
esta forma de atuação do professor assemelha-se ao chamado método socrático, descrito por Elkins (2002) como:

Comprometido com o exame rigoroso da fé e moralidade do seu tempo, dando lugar de destaque a essas convicções que são compartilhadas amplamente e raramente questionadas. A confiança em consensos e em paradigmas prestigiosos são alvos prioritários. No ensino socrático, exploramos 'alternativas compelativas dos modelos atuais'. Nós 'perguntamos como várias ortodoxias de nosso tempo parecem quando vistas do exterior, quão bem fundamentados é o nosso bom senso e todos os tipos de escolástica, bem como também os consensos não-acadêmicos e o que poderia ser dito a favor e contra cada alternativa'.

Finalizando, é importante enfatizar a possibilidade de se contribuir efetivamente, através de processos educativos organizados sem amadorismo ou espontaneísmo, para a melhoria da qualidade da assistência atuando diretamente com os profissionais envolvidos nela. Não há por que imaginar que não existe saída, aceitando o atual quadro de perversidade na assistência com desesperança. Só não se pode ficar com os braços cruzados.

NOTAS

1 Para maiores informações sobre essas abordagens, ver Rego (2003).

2 As idéias apresentadas aqui estão amplamente inspiradas no pensamento de Paulo Freire (2003).

3 Ver dois exemplos dos textos em Brasil $(1999,2001)$. Bem diferente de Brasil (1997), que apresenta o trabalho desenvolvido para o Ensino Fundamental e o Ensino Médio.

\section{REFERÊNCIAs BIBLIOGRÁfICAS}

BIAGgiO, A. M. B. Psicologia do Desenvolvimento. Petrópolis: Vozes, 1975.

BOURDIEU, P. Razões Práticas: sobre a teoria da ação. Campinas: Papirus, 1996. 
BRASIL. Secretaria de Educação Fundamental. Parâmetros Curriculares Nacionais: apresentação dos temas transversais, ética/Secretaria de Educação Fundamental. Brasília: MEC/SEF, 1997.

BRASIL. Portaria 126, 1 fev. de 1999, publicada no Diário Oficial de 2 de fevereiro de 1999. Diretrizes Curriculares Nacionais dos Cursos de Graduação em Medicina. Secretaria de Ensino Superior do MEC. Disponível em: http://www.mec.gov.br/sesu/ftp/Medicina-DC.rtf. Acesso em: 29 abr. 2004.

BRASIL. Resolução n. 3, 7 nov. de 2001. Diretrizes Curriculares Nacionais dos Cursos de Graduação em Enfermagem. Disponível em: http:// www.ccs.uel.br/nesco/observatorio/enfermagem.asp. Acesso em: 29 abr. 2004.

COHEN C. \& SEGRE M. Breve discurso sobre valores, moral, eticidade e ética. Bioética, 2(1): 1994. Disponível em: www.portalmedico.org.br/ revista/bio1v2/brevedis.html. Acesso em: 29 abr. 2004.

ELKINS, J. R. Socrates and the Socratic Method, 2002. Disponível em: http:/ /www.wvu.edu/ lawfac/jelkins/pmpl99/teachvirtue/socrates.html. Acesso em: 29 abr. 2004.

ENGELHARDT JR., H. T. Fundamentos da Bioética. São Paulo: Loyola, 1998. FIESER, J. Psychological Issues in Metaethics, 2003. Encyclopedia of Philosophy. Disponível em: http://www.iep.utm.edu. Acesso em: 10 jan. 2004.

FREIRE, P. Pedagogia da Autonomia - saberes necessários à prática educativa. Rio de Janeiro: Paz e Terra, 2003.

GILLIGAN, C. In a Different Voice: psychological theory and women's development. Massachusetts: Harvard University Press, 1998.

KANT, I. Fundamentos da Metafísica dos Costumes. Rio de Janeiro: Ediouro, s.d.

KILCULlEN, R. J. Adam Smith: the moral sentiments, 1996. Disponível em: http://www.humanities.mq.edu.au/Ockham/Opge6 764.html. Acesso em: 10 fev. 2003. 
KOTTOW, M. Ensinando Bioética: prioridade de substância sobre método. Revista Brasileira de Educação Médica, 26(2): 132-139, 2002.

LAPLANCHE, J. \& PONTALIS, J. B. Vocabulário da Psicanálise. São Paulo: Martins Fontes, 1992.

MACHADO, M. H. Médicos no Brasil: um retrato da realidade. Rio de Janeiro: Fiocruz, 1996.

MATURANA, H. Emoções e Linguagem na Educação e na Política. Belo Horizonte: UFMG, 1998.

NUCCI, L. P. Education in the Moral Domain. New York: Cambridge University Press, 2001.

PIAGET J. A Linguagem e o Pensamento da Criança. São Paulo: Martins Fontes, 1993.

PIAGET J. O Juízo Moral na Criança. São Paulo: Summus, 1994.

PIAGET, J. A Construção do Real na Criança. Rio de Janeiro: Ática, 1996.

REGO, S. Novas diretrizes curriculares: e a educação moral? Caderno de Currículo e Ensino, 2(4): 22-36, 2001.

REGO, S. A Formação Ética dos Médicos: saindo da adolescência com a vida [dos outros] nas mãos. Rio de Janeiro: Fiocruz, 2003.

ROSA, M. Psicologia Evolutiva. 8.ed. Petrópolis: Vozes, 1996. v.1 - Psicologia do Desenvolvimento.

TURIEL, E. The Culture of Morality: social development, context, and conflict. New York: Cambridge University Press, 2002. 


\section{Alocacão de Recursos na AssistênCla Materno-lNFANTIL}

5

Gabriel Eduardo Schütz

Fermin Roland Schramm

INTRODUCÃO

Poucos assuntos pertencentes ao campo de interesse da Bioética conseguem ser tão complexos e conflituosos quanto o da problemática da saúde materno-infantil, que inclui temas de grande relevância, como reprodução humana, controle da natalidade, direitos do feto, discriminação étnica e de gênero, entre outros.

Ademais, o panorama se complica ao assumir, em alguns casos, o caráter de um autêntico dilema moral, como o que consiste em discutir como deve ser feita, e a partir de quais critérios éticos, a alocação dos recursos necessários para financiar a saúde materno-infantil, pois é a partir desses critérios e das conseqüências práticas daí resultantes que a alocação poderá ser considerada moralmente correta ou não. Mas isso, embora necessário, ainda não é suficiente, visto que uma política de alocação de recursos deve também ser socialmente aceitável, tendo, portanto, uma inevitável interface com a política.

Com efeito, quando uma comunidade começa a discutir a implementação de um programa de assistência em saúde - principalmente no caso materno-infantil -, rapidamente percebe que, para alcançar o sucesso, a preocupação com a qualidade da assistência dos profissionais e dos equipamentos envolvidos no projeto não é suficiente. Também é preciso conhecer muito bem o contexto socioeconômico do público-alvo, suas características culturais, seus valores, suas crenças e sua capacidade de auto-organização. Em outras palavras, a discussão sobre como devem ser 
alocados os recursos públicos para atender as demandas da saúde maternoinfantil não começa nem termina na avaliação dos custos da montagem e manutenção do serviço médico em si próprio, pois é também preciso considerar as políticas sobre educação, adolescência, emprego, moradia, gênero, migração interna, entre outras, que são sempre, de alguma maneira, correlatas de uma política sanitária ética e socialmente aceitável.

\section{A RefleXÃo Bió́tica sobre Alocaç̃o de Recursos}

A reflexão bioética - implicando a pesquisa de regras de comportamento e análise crítica de valores morais - preocupou-se, de uma maneira muito ampla, com a questão da alocação de recursos, procurando compreender os princípios morais envolvidos nas tomadas de decisão no campo da saúde. Este interesse aumentou nas últimas décadas do século $\mathrm{XX}$, como conseqüência do constante e progressivo incremento dos gastos sanitários observados na maioria dos países, inclusive no Brasil, ao mesmo tempo que os recursos disponíveis para custeá-los mostraram-se não só finitos como também escassos (Schramm, 2000; Fortes, 2001).

A alocação de recursos para a saúde tornou-se, assim, um problema complexo cuja solução envolve, simultaneamente, aspectos sanitários, econômicos, políticos e morais não comensuráveis entre si, a princípio, visto que seu correto equacionamento deve satisfazer as necessidades de saúde da população e outras necessidades legítimas, tais como educação, segurança, trabalho e todas aquelas imprescindíveis para que se possa falar em vida decente, devendo-se, ainda, otimizar os meios disponíveis para a satisfação das necessidades de saúde no contexto das demais necessidades. Isto suscita, inevitavelmente, debates éticos e políticos sobre quais deveriam ser as escolhas mais razoáveis, moralmente legítimas e politicamente aceitáveis a serem feitas.

A abundante bibliografia que aborda a questão da alocação dos recursos desde o enfoque bioético distingue duas dimensões desse problema (Harris, 1998; Wikler \& Marchand, 1998; Fortes, 2001): 
- Microalocação - diz respeito à análise e discussão dos critérios de alocabilidade, assim como às conseqüentes formas de seleção individualizada de pessoas que poderão ser beneficiadas com os serviços médicos. Envolve, por exemplo, os critérios de seleção de pacientes nos casos de vagas insuficientes em hospitais ou serviços de terapia intensiva, recebimento de órgãos para transplantes, utilização de hemodiálise, entre outros.

- Macroalocação - diz respeito também aos critérios de alocabilidade e às respectivas conseqüências da alocação e distribuição dos recursos financeiros, mas referindo-se à saúde coletiva, com especial enfoque nas políticas públicas de saúde e na organização dos sistemas de serviços médicos.

Para o bioeticista Miguel Kottow (2000), entre microalocação decidida no nível profissional - e macroalocação - decidida no nível das políticas públicas - existiria uma dimensão intermediária, constituída por uma mesoalocação. Neste nível de decisão, os gestores/administradores de serviços públicos de saúde deveriam encontrar critérios de alocação que sejam ao mesmo tempo moralmente legítimos e tecnicamente eficazes para garantir o funcionamento dos seus serviços com a verba orçamentária que lhes foi destinada.

Na prática, muitas vezes, este 'tomador de decisões' de nível intermédio não pode respeitar qualquer planejamento orçamentário racionalmente discutido, visto que deve atender primeiro ao cumprimento de sentenças judiciais em benefício de pacientes que procuraram a justiça na busca de garantir os benefícios que a Constituição lhes dá direito.

Querendo contextualizar historicamente esta discussão, seria possível dizer que a problemática da microalocação pertence à chamada primeira fase da Bioética, ou 'Bioética privada' (também conhecida como 'clínica'), que envolve os conflitos da relação entre médico e paciente e cuja característica principal é a utilização conceitual do principialismo ${ }^{1}$ (Schramm, 1997). Mais precisamente, o fato considerado como marco do nascimento da Bioética envolveu a microalocação de um serviço médico, pois houve uma grande comoção pública depois que a mídia publicou um 
artigo $^{2}$ em que se contava a história de um comitê - estabelecido em 1961, na cidade de Seattle, nos Estados Unidos - cuja missão era selecionar os pacientes que receberiam tratamento de hemodiálise (naquele tempo, uma nova tecnologia e raramente usada). Os responsáveis pelo serviço logo perceberam que havia muitas pessoas que precisavam do tratamento, mas era evidente que nem todas poderiam ser atendidas. A solução encontrada foi encomendar a um grupo de pessoas, de preferência não-médicos, a delicada tarefa de selecionar, com base em critérios diferentes dos clínicos, quem deveria ser beneficiado e quem não (Lolas Stepke, 1997).

Na atualidade, os polêmicos conflitos emergentes da microalocação de serviços médicos de alta complexidade ainda não encontraram um caminho inequívoco de resolução. Muito pelo contrário, o rápido avanço da tecnologia e, conseqüentemente, dos custos destes serviços, faz crescerem situações em que enfermeiros, médicos e gestores de saúde devam enfrentar este tipo de 'escolhas trágicas'. Em contextos de escassez de recursos muito severa, tal como é o caso de muitos serviços de saúde na América Latina, os conflitos de microalocação estendem-se à maioria das práticas médicas, inclusive às de baixa complexidade. Em particular, os profissionais da saúde envolvidos na saúde materno-infantil conhecem de perto estes dilemas morais quando devem decidir como ocupar, por exemplo, as vagas nas unidades de tratamento intensivo (UTIs) neonatal e pediátrica.

Caberia esperar que a gestão e o planejamento em saúde pública desenvolvam ações tendentes a resolver, ou pelo menos aliviar, os problemas de alocação nos serviços médicos em que a procura pelas práticas da atenção costuma exceder a capacidade de resposta técnica e/ou humana disponível. Porém, a realidade indica que não há disponibilidade de recursos públicos suficientes para atender a toda possível demanda em saúde. Com efeito, de acordo com Schramm (2000), os sistemas sanitários com vocação universalista $^{3}$ não podem incorporar indefinidamente despesas, sob o risco de irem à falência. Ao mesmo tempo, também não podem restringir a 'integralidade' da assistência médico-hospitalar para não perder sua identidade e legitimidade, visto que ela constitui uma das três diretrizes fundamentais do Sistema Único de Saúde (SUS) brasileiro, garantido por lei. 
Entretanto, não existindo recursos suficientes para dar resposta à totalidade das necessidades de saúde e tendo de se estabelecer prioridades na alocação e na distribuição dos recursos, surgem as seguintes perguntas: quais os critérios técnicos e os valores sociais e éticos a serem levados em conta na tomada de decisão? Deve o Estado restringir o acesso de determinadas e custosas tecnologias para prover as necessidades 'básicas' da maioria? Neste caso, como estabelecer quais são as necessidades 'básicas'? Pode-se contrapor a prática de procedimentos onerosos destinados a poucas pessoas a outra, destinada a mais pessoas, e isso tão-somente devido a razões orçamentárias? Ou será necessário lançar mão de outras razões? Como se compreende o que seja utilidade social? Ela deve ser avaliada em termos médicos ou sociais? Como medir benefícios em saúde (Fortes 2001)?

Todas essas perguntas delineiam um conjunto de conflitos morais que adquirem paulatinamente relevância pública - e isso em um momento em que a tradicional abordagem principialista, aplicada com relativo sucesso e resolutividade na Bioética clínica, mostra-se insuficiente como método confiável para resolver conflitos públicos envolvendo uma série de valores e princípios, de fato inconciliáveis entre si (Schramm \& Kottow, 2001).

Ainda segundo Schramm (1997), uma nova fase da Bioética - a fase 'pública' ou 'fase dos conflitos' - teria de fato começado a ser discutida no início da década de 1990 ao introduzir a problemática da macroalocação e, com ela, as demandas da justiça social nas pautas dos debates bioéticos. E não poderia ser de outra maneira no contexto sanitário da América Latina, pois a região tem sido caracterizada, por várias fontes fidedignas nacionais e internacionais, como a de maior iniqüidade do mundo. Existem evidências mostrando que a desigualdade social tem aumentado em muitos países da região, e até na região como um todo, durante os últimos 20 anos, agravando, portanto, os problemas de exclusão social, que se têm tornados crônicos (Larrea, 2002).

Tais disparidades sociais na América Latina têm um reflexo direto nos dados estatísticos sobre mortalidade e desnutrição infantil, gravidez na adolescência, violência contra mulher e a criança etc. Neste contexto, 
expressões como 'direito à vida (digna)', 'direito à saúde' e 'justiça sanitária' costumam aparecer nos discursos sobre a saúde na região. Porém, o significado conferido a estes termos é bastante ambíguo tanto no mundo acadêmico quanto no político. De fato, existe algum dever moral que obrigue a dar assistência médica a alguém? Se sim, a quem? Por quê? Em quais circunstâncias? Ademais, quem deve assumir a responsabilidade desta obrigação? E, de forma mais geral, qual é o papel do Estado na assistência à saúde?

A análise histórica indica que no período pré-moderno existiram alguns modelos de assistência coletiva à saúde, mas que estes eram do tipo solidariedade local ou comunitária, baseados em laços de pertença, tradição e parentesco, e, também, com um forte apelo religioso (Walzer, 2001; Giddens, 1991). Na Idade Média, por exemplo, existiram serviços de assistência sanitária financiados pelo poder central, mas eram inspirados em sentimentos de piedade e caridade cristã - este foi o caso do rei Luís IX, da França (1215-1270), que se tornou São Luís (Grinberg \& Svanström, 1984). Porém, em nenhum período pré-moderno chegou a existir um orçamento organizado pelo Estado (Weber, 1980). Foi preciso que as revoluções científicas e democráticas da modernidade se consolidassem para que o Estado, propriamente dito - isto é, secularizado -, assumisse o compromisso de garantir os direitos sociais ${ }^{4}$ de todos os seus cidadãos (Schütz, 2003).

Contudo, resta mais uma questão: qual ó lugar da saúde nos direitos sociais? A Constituição da Organização Mundial da Saúde, em julho de 1948, interpretou a saúde como "um estado de bem-estar físico, mental e social, e não unicamente a ausência de doença ou enfermidade", e proclamou o que seria o 'direito à saúde': "poder gozar do mais elevado nível de saúde possível é um dos direitos fundamentais de cada ser humano, sem distinção de raça, religião, ideologias políticas, condições econômicas e sociais" (OPS, 1990: 241). Por sua parte, a Declaração Universal dos Direitos do Homem da Organização das Nações Unidas (ONU), também assinada em 1948, no comumente apontado artigo 25 , refere-se ao "direito a um nível de vida que lhe permita assegurar a saúde para si e para sua família [cujas condições 
indispensáveis de efetivação apontam] a alimentação, o vestuário, a habitação, os cuidados médicos, assim como os serviços necessários" (OPS, 1990: 242). Desde este enfoque, a saúde apresenta-se, portanto, como indissociável de outros bens de ordem social e vem, conseqüentemente, integrar a categoria dos direitos sociais que devem ser garantidos pelo Estado. A partir disso, saúde já não é mais só uma questão privada, do âmbito do indivíduo ou da relação médico-paciente, mas uma questão de política pública, que implica, portanto, considerar o contexto público. Em especial depois da Segunda Guerra Mundial a saúde passou a ser considerada como um dos mais importantes direitos sociais.

Porém, não existem tais direitos sociais até não serem encarnados em instituições concretas através da lei (Daniels, 1998). Com efeito, para realizá-los na prática, toda a comunidade envolvida, isto é, propriamente 'cidadã', deve discutir a maneira em que a lei-que, por princípio, garante os direitos - deve ser interpretada e aplicada nos casos e contextos concretos.

No caso específico do direito à assistência médica - incluindo os cuidados à saúde materno-infantil -, é necessário diferenciar rigorosamente o 'direito à vida e à integridade física da pessoa humana' - direito humano que o Estado deve proteger em termos absolutos por se tratar de direitos que constituem condição necessária para os demais - do 'direito à saúde'5 - direito social que o Estado deve primeiro formular em seus conteúdos e abrangência para depois poder garanti-lo concretamente, tornando-se, assim, uma condição que podemos chamar de suficiente, porque pode realizar concretamente o bem-estar em termos de saúde.

No entanto, da inter-relação entre esses dois tipos de direitos e as (supostas) obrigações morais que lhes dizem respeito, emergem os mais acalorados debates bioéticos sobre a alocação de recursos para a saúde. Para alguns autores, como Engelhardt (1998) e Nozick (1974), não existe imperativo moral algum que obrigue a dar assistência médica a quem precisa e não pode pagá-la. Já para a Constituição brasileira - como já foi mencionado -, o Estado é obrigado a assistir, com total cobertura médica, a todos seus cidadãos irrestritamente. Finalmente, bioeticistas latinoamericanos, como Schramm e Kottow (2001), consideram que é função e 
responsabilidade de um Estado moralmente legítimo dar 'proteção sanitária' aos cidadãos, em particular aos mais necessitados e desamparados, e isso do ponto de vista de uma 'ética da proteção' que seja eqüitativa, logo não necessariamente universal.

Para um melhor entendimento das propostas de alocação de recursos destinados à assistência médica coletiva defendida por cada uma dessas linhas do pensamento bioético, é preciso analisar, primeiro, as definições de justiça distributiva e os fundamentos morais contidos nas respectivas argumentações.

\section{A questão dA JUSTIÇA DISTRIBUTIVA}

$\mathrm{Na}$ tradição ocidental, desde os tempos de Platão e Aristóteles, a justiça distributiva é concebida como 'a virtude de dar a cada um o que lhe é próprio'. Porém, existem diversas interpretações históricas a respeito do que significa 'dar', de quem deve ser 'cada um' e, principalmente, do que representa 'o que lhe é próprio'. Por exemplo, qual seria o conteúdo dessa definição no caso dos direitos envolvendo a vida e a integridade física, por um lado, e a assistência à saúde, por outro?

No primeiro caso, trata-se de um direito humano ('dado' como herança pela tradição humanista moderna). Conseqüentemente, toda pessoa humana ('cada um') merece a proteção de sua vida e integridade física ('o que lhe é próprio'). Concretamente, esse direito significa obrigações morais que devem ser respeitadas pelos 'outros', mas não obriga a promover qualquer tipo de benefício nem se propõe a alcançar objetivo algum, garantindo tão-somente a ausência de danos a terceiros (não-maleficência). Trata-se, em suma, de uma moral mínima que impõe restrições de tipo deontológico. ${ }^{6}$

No segundo caso, o direito social à assistência à saúde apresenta outras características: para garantir ('dar') a assistência a quem precisa (a 'cada um') para que recupere a saúde ('o próprio'), é preciso agir em benefício de um "outro". Trata-se, em outros termos, de uma moral máxima que obriga o agente a agir de maneira teleológica, ${ }^{7}$ isto é, em busca de um objetivo (beneficência). Agora, se é relativamente fácil imaginar que existe um certo tipo de obrigação moral para agir quando o possível beneficiário 
está unido ao agente beneficente por laços afetivos ou de responsabilidades previamente assumidas, pode-se razoavelmente perguntar: qual é a obrigação moral de socorrer alguém quando o outro é um perfeito estranho? Ou seja, quando o outro é - nos termos de Engelhardt (1998) - um 'estranho moral'?

A resposta a esta pergunta constitui, sem dúvidas, o principal ponto de divergência entre os autores que analisam a questão da justiça sanitária. Segundo Ronald Dworkin (1977), esta divergência se deve ao fato de que haveria três teorias normativas básicas em condições de responder, de maneira diferente, a esta questão, a saber: 1) teorias baseadas em objetivos; 2) teorias baseadas em direitos; 3) teorias baseadas em deveres.

As teorias baseadas em objetivos são aquelas para as quais há um objetivo supremo a ser promovido pela ação estatal ou a ação política, objetivo ao qual a atribuição de direitos e deveres aos indivíduos deve se subordinar. No entanto, estas teorias não são de grande relevância no debate bioético acadêmico e laico. As duas seguintes - as teorias baseadas em direitos e as baseadas em deveres - são modalidades do assim chamado individualismo moral, tendo em vista que, para umas e outras, a fonte última do valor é o bem-estar de indivíduos. Porém, a preocupação com o bem-estar individual pode estar mais centrada na noção do direito ou, alternativamente, mais centrada na noção de dever. Fazer esta distinção pode parecer estranho, principalmente porque 'direito' e 'dever' são indissociáveis na concepção de justiça mais imediata do senso comum. Com efeito, o que se pede à justiça é que ela dê o direito como um debitum. Em outras palavras, o direito manda ('caráter imperativo') dar a cada um o que lhe é devido; ao mesmo tempo, o direito atribui alguma coisa ('caráter atributivo') (Mata Machado, 1995). Contudo, a normativa fundamentada no individualismo moral depende fortemente da ênfase que se dê a um ou a outro.

Um exemplo de individualismo moral com ênfase nos direitos é dado pela concepção de justiça sanitária que fundamenta o Estado de bem-estar e que está baseada nos 'direitos' sociais que as pessoas possuem na qualidade de cidadãos. Segundo esta perspectiva, um indivíduo 'A' tem um direito a ' $\mathrm{X}$ ' ('assistência sanitária') se é plausível sustentar que há um aspecto 'a' 
do bem-estar de 'A' ('saúde') que consideramos tão importante eticamente a ponto de fundamentar a imposição de um dever ' $\mathrm{Y}$ ' a outro indivíduo 'B' e relativo a um ato 'b' ('pagar impostos'). Com respeito aos deveres, estes não são valorizados em si mesmos, mas como instrumentos para a proteção de interesses individuais aos quais se atribui um significado moral ('saúde'). O que importa são as condições (estado de coisas) que permitam a cada um se empenhar ativamente na realização daquilo que julga ser valioso na vida (Vita, 2000).

Um agente moral que considera desejável atingir um estado de coisas em que os direitos de todos sejam protegidos não está apenas valorizando seus próprios interesses, mas também atribuindo relevância moral aos interesses mais fundamentais dos outros, mesmo que estranhos à sua pessoa. Quando as instituições básicas da sociedade incorporam uma consideração igual e imparcial pelo bem-estar de todos, então cada pessoa pode considerar-se livre - moralmente falando - para viver sua própria vida à sua maneira e dar o peso necessário às obrigações especiais que deve reconhecer sua conduta (Vita, 2000). A partir deste ponto de vista, a justiça somente é alcançada quando todos os indivíduos possuem liberdade e autonomia suficientes para alcançar seu bem-estar e para escolher, entre os diferentes tipos de vida alcançáveis, aquela que consideram a mais digna de ser vivida.

Em resumo, os pressupostos básicos do individualismo moral, baseado em direitos, são os seguintes: 1) a vida de todas as pessoas tem valor e um igual valor; 2 ) cada pessoa tem sua vida para levá-la segundo sua própria concepção de bem-estar; 3) a saúde tem prioridade lexical como condição de realização dos outros valores.

Entre as teorias teleológicas que subsidiam a alocação de recursos para saúde, destacam-se duas baseadas em direitos: o utilitarismo e o igualitarismo. Ambas estão baseadas na relevância moral da satisfação das preferências individuais. Porém, se diferenciam no que diz respeito ao valor dessas preferências para determinar os critérios distributivos. 


\section{UTILITARISMO E IGUALITARISMO}

Enquanto o utilitarismo exige que os indivíduos ajam de forma a maximizar o total da utilidade (seja 'líquida' ou per capita), o igualitarismo centra a sua atenção nos arranjos institucionais a que os indivíduos devem contribuir para conseguir (do ponto de vista dos 'efeitos ou conseqüências') que os encargos e benefícios da sociedade sejam eqüitativamente distribuídos.

O utilitarismo apresenta duas grandes desvantagens: 1) os objetivos e valores comuns prevalecem sempre sobre os objetivos individuais; 2) sua base moral permite a barganha de interesses relacionados à vida e à liberdade de um pequeno grupo de pessoas por uma soma maior de interesses, quando comparada com interesses menores de outros (Vita, 2000).

Por sua vez, a grande desvantagem do igualitarismo é que considera 'iguais' todas as pessoas quando, na verdade, as pessoas nascem em condições iniciais desiguais e estão dotadas com capacidades diferentes, o que se reflete fortemente na hora de exercerem sua cidadania. Efetivamente, em sociedades com distribuição assimétrica dos bens sociais (riqueza, educação etc), as políticas igualitárias (universalistas) de alocação de recursos para a saúde não têm, de fato, efeitos igualitários (ou são intimamente contraditórios).

O que se observa, na prática, é uma focalização sui generis da assistência em saúde, na qual a alocação dos recursos está determinada pelo poder de barganha dos indivíduos ou grupos sociais com melhores condições de negociação, os quais acabam, portanto, sendo favorecidos. Dessa maneira, os fundamentos morais que legitimam o igualitarismo na teoria vêem-se desvirtuados na prática (Schütz, 2003). Isto é particularmente dramático no caso da saúde materno-infantil, quando os envolvidos - mulheres e crianças, em geral pobres - aparecem entre os grupos sociais com menores condições de barganha.

Em contraste com o Estado de bem-estar, o modelo de Estado liberal ${ }^{9}$ está baseado em uma concepção do individualismo moral que dá maior ênfase aos 'deveres'. A preocupação central desta perspectiva restringe-se 
à não-violação de deveres morais - por indivíduos ou pelo Estado -, quaisquer que sejam as conseqüências disso, inclusive para a proteção dos direitos individuais.

\section{A neutralidade do Estado liberal}

A autocompreensão do Estado liberal consiste em considerar-se 'neutro' e limitar-se a institucionalizar (em lei) as restrições deontológicas. Os deveres obrigam a evitar a maleficência (não matar, não roubar, não mentir), mas as restrições não exigem que o agente se empenhe para que essas coisas não ocorram no mundo, pois isso seria uma interferência indevida nos espaços de liberdade de cada um.

Em suma, cada um está obrigado a cumprir seus próprios deveres, mas ninguém está obrigado a contribuir para que os outros possam cumprir com os seus. A partir deste ponto de vista, nenhuma pessoa é moralmente responsável pelos danos ou privações que outras sofram porque deixou de realizar o que estava ao seu alcance para evitar esse dano ou diminuir esse sofrimento. Contribuir para minorar o sofrimento de pessoas que vivem em um Estado de privação atroz pode ser meritório para os mais abastados, mas o sofrimento de outros não autoriza moralmente o Estado a tomar compulsoriamente recursos - por mínimos que sejam - dos ricos para distribuições sociais (Vita, 2000). Esta perspectiva é defendida, por exemplo, por Nozick (1974) e por Engelhardt (1998).

As concepções de justiça fundamentadas em deveres são a base moral do neoliberalismo, teoria política que, desde a década de 1980, se expande pelo mundo ocidental com a globalização. Para Álvaro de Vita (2000), esta 'moral' neoliberal se apresenta como a maior defensora da 'liberdade individual', mas, na verdade, está preocupada apenas com a liberdade contratual e com a propriedade. Se a liberdade individual fosse um valor moralmente relevante - argumenta Vita -, a sociedade justa seria aquela que a garantisse a todos os seus membros. O autor conclui que a 'moral neoliberal', de fato, rejeita os direitos que derivam de uma consideração imparcial pelo bem-estar de todos, ao desobrigar os membros de uma comunidade da responsabilidade moral pelos menos favorecidos. 
Na visão deontológica do Estado liberal, a sociedade justa é aquela que garante a propriedade adquirida em conformidade com os princípios de aquisição e transferência e não permite que 'ninguém' (indivíduo ou Estado) possa ameaçar a propriedade - para isto é que necessita das restrições morais que fundamentam sua moral.

Nozick (1974), por exemplo, considera que a propriedade é o valor moral de maior relevância. Para este autor, o Estado liberal neutro não deve somente levar em conta as constrições morais, mas deve também respeitá-las de forma absoluta, de maneira a não ameaçar a propriedade dos cidadãos. Segundo sua perspectiva, se um Estado obriga uma pessoa (mais privilegiada) a contribuir para o bem-estar de outra (mais desafortunada) age como um Estado que não é neutro entre seus cidadãos; neste caso - o que é pior -, o Estado estaria utilizando um cidadão como instrumento para os fins de outro, o que infringiria o imperativo prático kantiano. Mas, de acordo com Vita (2000), esta seria uma interpretação um tanto forte da moral kantiana.

Também Engelhardt (1998) defende, com veemência, a aplicação das teses do liberalismo à problemática da alocação de recursos em saúde. Para o autor, o recurso a idéias de justiça social na formação das políticas de assistência à saúde pode ser desonesto ao sugerir um acordo canônico em uma reflexão moral secular. E pode ser, também, demagógico, provocando o uso coercitivo da força não-justificada do Estado. Segundo Engelhardt, se uma pessoa possui propriedades de justa aquisição ou de justa transferência, então sua posse sobre aquela propriedade não poderá ser prejudicada pelas tragédias e necessidades dos outros. Na mesma linha de raciocínio, Nozick (1974) afirma que toda transferência de titularidades involuntária é inadmissível devido ao fato de que todas as coisas que existem nascem vinculadas a pessoas que têm titularidade sobre elas e que contam com elas para desenvolver seus projetos de vida.

\section{Crítica ao Estado liberal}

Para o ambientalista Guillermo Foladori (2001), aconteceria exatamente o contrário: cada nova geração de humanos não iniciaria em 
igualdade de condições, como seria o caso de qualquer outra espécie viva. ${ }^{10}$ De fato, as gerações de humanos começariam com uma bagagem desigual de coisas produzidas, acumuláveis extracorporalmente, fora da herança genética e, portanto, não imputáveis à necessidade imposta biologicamente. O autor chama tais diferenças, com base material, de 'diferencias sociais'.

Parece óbvio que a aplicação irrestrita do ponto de vista defendido por Nozick e Engelhardt no contexto da América Latina comprometeria a continuidade dos programas de saúde materno-infantil. A resposta dos pensadores liberais a este tipo de demanda social é a caridade, a qual consideram meritória, mas não compulsória.

Embora a aplicação de um programa liberal seja socialmente inadmissível na América Latina, visto que estenderia as diferenças e injustiças sociais, também não é possível continuar insistindo no fato de que um modelo igualitarista, universal e irrestrito é de fato sustentável. Com efeito, mesmo que fosse muito sensato em teoria e, talvez, desejável na prática, este modelo não apresenta concretamente os efeitos desejados (acesso e cobertura total a todos) nos contextos de escassez de recursos combinados com profundas injustiças sociais. Em outras palavras, o modelo igualitarista pode, talvez, funcionar em sociedades pequenas, de 'amigos morais', solidários entre si devido ao mútuo reconhecimento e a valores e interesses substanciais compartilhados, mas dificilmente se aplica a sociedades complexas de 'estranhos morais', como são as sociedades pluralistas contemporâneas (Engelhardt, 1998), pois exigiria que todos seus cidadãos tivessem atingido um estágio moral bastante elevado e compartilhassem um grau de responsabilidade em relação a seus semelhantes que desse sempre a prioridade ao Outro sobre si mesmo, como é o caso da ética proposta por Emmanuel Levinas (1997).

\section{Qual Alternativa?}

Uma possível alternativa aos modelos anteriores poderia ser uma política de alocação de recursos baseada na 'eqüidade'. Esta teoria - que tem antecedentes teóricos em Aristóteles - nasceu em 1971, quando John Rawls publica seu livro Uma Teoria da Justiça. Nesta obra clássica da filosofia 
do direito, Rawls levanta uma questão particularmente importante ao afirmar que só existe justiça entre iguais. Mas se as pessoas não são iguais de facto, a justiça deve ser entendida não como 'igualdade', mas como 'eqüidade'. Em outros termos, para Rawls, a distribuição dos 'valores sociais' (liberdade e oportunidade, renda e riqueza e as bases sociais da auto-estima) deve ser igualitária entre os 'iguais'; contudo, tratamentos desiguais poderiam ser justificados sempre que este 'tratamento desigual para os desiguais' trouxesse vantagens aos mais necessitados e, simultaneamente, desde que as liberdades fundamentais e o bem-estar de todos fossem respeitados (Rawls, 1997).

Entretanto, a concepção de justiça de Rawls se presta a algumas sérias críticas. O economista Amartya Sen (2001) critica, por exemplo, a rigidez dos parâmetros rawlseanos de avaliação das desigualdades. Este autor afirma que não é tão importante garantir distribuições justas dos 'bens individuais' (como, por exemplo, a renda), já que, na realidade, as circunstâncias individuais e sociais têm variações decisivas na desigualdade. Sen postula que o que deveria ser igualado numa sociedade justa é a 'capacidade de funcionamento' (capability), isto é, a oportunidade de cada indivíduo para levar sua vida de acordo com suas escolhas e seus valores. Para isto, o indivíduo precisaria desenvolver suas 'vantagens individuais', o que inclui vocação, habilidades, talentos etc. Estes conceitos seneanos apostam fortemente na autonomia e na liberdade individual para poder definir o que deve, afinal, ser entendido concretamente por 'bem-estar'.

\section{CONCLUSÃO}

Seria possível afirmar que as pessoas são desiguais em quase todos os aspectos, sendo iguais em apenas dois: 1) elas têm 'igual dignidade' (igual valor da vida humana); 2) todas apresentam potencialmente 'igual fragilidade' ou 'desamparo' (no sentido freudiano da palavra Hilflosigkeit, literalmente, 'sem ajuda alguma') frente às doenças e catástrofes (que constituem a 'vulnerabilidade natural' da condição humana).

De acordo com a proposta de uma 'ética da proteção', formulada por Schramm \& Kottow (2001), as medidas sanitárias preventivas devem ser 
universais ('igualitárias') porque a vulnerabilidade natural, considerada como fragilidade intrínseca à condição humana do indivíduo, é comum a todos. Porém, de acordo com o princípio de eqüidade, as políticas sanitárias restaurativas não podem ser igualitárias, devendo, logicamente, ser 'focalizadas', isto é, dando prioridade para aqueles que não podem custear os procedimentos que necessitam para recuperar sua saúde e, com ela, sua capacidade de funcionamento. Segundo os autores, quem precisa de cuidados sanitários já não é mais tão-somente 'vulnerável' como qualquer representante da espécie Homo sapiens sapiens, mas, sim, 'vulnerado' ou atingido, que precisa de assistência à saúde para recuperar sua autonomia e, com ela, a possibilidade de escolher que tipo de vida quer para si.

Em particular, a proposta de justiça sanitária baseada em uma 'bioética da proteção', como aquela elaborada por Schramm e Kottow (2001), apresenta-se como a que melhor se ajusta às exigências de eqüidade em contextos de escassez, especialmente para países não-desenvolvidos, nos quais a dívida com a saúde (e com outros bens essenciais) vem somar-se à lista da dívida pública que o Estado não está conseguindo 'pagar'. Com efeito, esta proposta é fortemente eqüitativa ao diferenciar entre 'vulneráveis' (iguais), que precisam prevenir os problemas de saúde, e os 'atingidos' (desiguais), que precisam de cuidados sanitários especiais ou adicionais para recuperar sua saúde.

Pode-se, portanto, concluir que todo investimento em saúde está eticamente legitimado, já que a saúde é um valor social que tem 'prioridade lexical' no sentido de constituir a condição necessária para a realização de todos os outros valores desejáveis e realizáveis pelos indivíduos. Contudo, em uma sociedade que tenha como uma de suas características fundamentais o pluralismo de valores morais, cabe à própria sociedade, através dos mecanismos democráticos de participação, a construção de uma política sanitária em que não existam pessoas excluídas nem negligenciadas.

A responsabilidade do Estado de 'proteger' a saúde de forma eqüitativa é sensivelmente importante para a implementação de políticas e programas de saúde materno-infantil. Embora não lhe seja possível evitar 
a 'loteria natural' que adjudica a algumas pessoas capacidades diferentes, muitas vezes não desejadas, ao menos se perfila como um modelo para reduzir os efeitos da 'loteria social' que prejudica muitos cidadãos que não tiveram a fortuna de nascer em um 'berço esplêndido'.

\section{NotAs}

1 Chama-se de principialismo a aplicação de quatro princípios - não-maleficência, beneficência, autonomia e justiça - como modelo teórico para resolver conflitos morais em Bioética.

2 Trata-se do artigo "They decide who lives, who dies" ['Eles decidem quem vive, quem morre'], publicado na revista Life de 9 de novembro de 1962, pela jornalista Shana Alexander.

3 É o caso de Brasil, que garante, no artigo 196 da Constituição Federal, "a saúde [como] um direito de todos e um dever do Estado".

4 Os direitos sociais são aqueles que precisam de um Estado que formule seu conteúdo em lei e os efetive na prática. Em contraste com os direitos humanos, que são prévios ao Estado e pertencem por igual a todos aqueles que nascem pessoas humanas.

5 O direito à saúde é entendido aqui como o direito de quem precisa de assistência médica ou sanitária.

6 A visão deontológica (do grego deon e ontos, 'dever ser') está caracterizada por princípios abstratos que estabelecem o que se deve fazer, independentemente das conseqüências e dos contextos, tendo, portanto, uma prioridade lexical sobre o justo e o injusto, que serão conteúdos derivados do respeito ao dever.

7 A visão teleológica (do grego telos, 'fim', 'finalidade') avalia as conseqüências e finalidades práticas dos atos.

8 Trata-se do welfare state, tal o caso do modelo assistencialista praticado nos países da Europa Ocidental pós Segunda Guerra Mundial.

9 Os Estados Unidos representam o melhor exemplo de modelo de assistência à saúde de tipo liberal.

10 Cada nova geração dos seres vivos, com exceção do Homo sapiens sapiens, nasce com igual probabilidade de acessar a bagagem genética da sua espécie. As propriedades geneticamente herdadas são aleatórias, submetidas a uma 'loteria natural' . 


\section{ReferênCIAs Bibliográficas}

DANIELS, N. Is there a right to health care and, if so, what does it encompass? In: KUHSE, H. \& SINGER, P. (Eds.) A Companion to Bioethic. New York: Oxford, 1998.

DWORKIN, R. Taking Rights Seriously. London: Duckworth, 1977.

ENGELHARDT, H. T. Jr. Fundamentos da Bioética. São Paulo: Loyola, 1998. FOLADORI, G. Limites do Desenvolvimento Sustentável. Campinas: Unicamp, 2001. FORTES, P. Dilemas éticos na alocação de recursos em saúde. In: PALÁCIOS, M.; MARTins, A. \& PEGORARO, O. (Orgs.) Ética, Ciência \& Saúde. Petrópolis: Vozes, 2001.

GIDDENS, A. As Conseqüências da Modernidade. São Paulo: Unesp, 1991. GRINBERG, C. \& SVANSTRÖM, R. La Edad Media. Buenos Aires: Circulo de Lectores, 1984.

HARRIS, J. Micro-allocation: deciding between patients? In: KUHSE, H. \& SINGER, P. (Orgs.) A Companion to Bioethic. New York: Oxford, 1998.

KOTTOW, M. Bioética e política de recursos em saúde. In: GARRAFA, V. \& COSTA, S. I. F. (Orgs.) A Bioética no Século XXI. Brasília: UnB, 2000.

LARREA, C. Desigualdad social, salud materno-infantil y nutrición en ocho países de América Latina: análisis comparativa de las encuetas DHS III. OPS-OMS, 2002. Disponível em: http://www.paho.org/Spanish/HPP/ HPN/larrea-encuestaDHS.htm. Acesso em: 10 jan. 2004.

LEVINAS, E. Entre Nós: ensaios sobre a alteridade. Petrópolis: Vozes, 1997.

LOLAS STEPKE, F. Bioética: una palabra con historia, 1997. Disponível em: http://www.uchile.cl/bioetica/doc/biohis.htm. Acesso em: 10 jan. 2004.

MATA MACHADO, E. Elementos de Teoria Geral do Direito. Belo Horizonte: UFMG, 1995.

NOZICK, R. Anarchy, State and Utopia. New York: Basic Books, 1974.

ORGANIZAÇÃO PANAMERICANA DA SAÚDE (OPS). Bioética. Publicação científica n. 527. Washington: Opas, 1990. 
RAWLS, J. Uma Teoria da Justiça. São Paulo: Martin Fontes, 1997.

SCHRAMM, F. R. Da Bioética privada à Bioética pública. In: FLEURY, S. (Org.) Saúde e Democracia: a luta do Cebes. São Paulo: Lemos, 1997.

SCHRAMM, F. R. Bioética, economia e saúde: direito à assistência, justiça social, alocação de recursos. Revista Brasileira de Cancerologia, 46(1): $41-47,2000$.

SCHRAMM, F. R. \& KOTTOW, M. Principios bioéticos en salud pública: limitaciones y propuestas. Cadernos de Saúde Pública, 17(4): 949-956, 2001.

SCHÜTZ, G. Quando o "igual tratamento" acaba em injustiça: um paradoxo bioético das políticas sanitárias universalistas de alocação de recursos, 2003. Dissertação de Mestrado, Rio de Janeiro: Escola Nacional de Saúde Pública, Fiocruz.

SEN, A. Desigualdade Reexaminada. Rio de Janeiro: Record, 2001.

VITA, A. de. A Justiça Igualitária e Seus Críticos. São Paulo: Unesp, 2000.

WALZER, M. Las Esferas de la Justicia: una defensa del pluralismo y la igualdad. México: Fondo de Cultura Económica, 2001.

WEBER, M. História Geral da Economia. Coleção Os Pensadores. São Paulo: Nova Cultural, 1980.

WIKLER, D. \& MARCHAND, S. Macro-allocation: dividing up the health care budget. In: KUHSE, H. \& SINGER, P. (Eds.) A Companion to Bioethic. New York: Oxford, 1998. 


\section{Bió́tICA E BIODIREITO:}

QUEM DEFENDE OS INTERESSES DA CRIANCA?

6

Heloisa Helena Barboza

\section{INTRODUCÃO}

Parecem indiscutíveis as maravilhas que as denominadas biotecnociências trouxeram a uma sociedade talvez ainda não preparada para assimilá-las por completo. Exatamente por esse aspecto, parece também não haver dúvida quanto às angústias e aos confrontos que as mesmas vêm gerando em diversos campos do conhecimento humano.

Do mesmo modo, em nenhuma outra época a medicina se especializou tanto e encontrou meios diagnósticos e terapêuticos tão sofisticados, ou dispôs de aparato tecnológico tão avançado. Na mesma medida, porém, aumentaram os conflitos dos médicos: até quando devem ser utilizados os recursos disponíveis e em que medida? Permanece uma obrigação do médico manter a vida a qualquer custo, ainda que os benefícios sejam diminutos em relação à probabilidade de danos ou seqüelas provocados, ou quando se está diante de um quadro irreversível? Neste último caso, é possível se admitir a distanásia?

A orientação hoje vigente é no sentido de respeitar, sempre que possível, a vontade do paciente, embora sejam rejeitados, na maioria dos países, o suicídio assistido e a eutanásia, só permitida na Suíça, Holanda e Bélgica. Se o doente está impossibilitado de manifestar-se, a família em geral considerada a guardiã do enfermo - tem assumido tal responsabilidade. Deve-se advertir, contudo, que esse entendimento está longe de ser pacífico, merecendo análise específica. 
De qualquer modo, tratando-se de adulto, pessoa maior e capaz, a observância da sua vontade encontra amparo no princípio bioético da autonomia, nos cânones do biodireito (Barboza, 2003) e no Código de Ética Médica, cumpridas que sejam as regras sobre a eficácia das declarações de vontade e as limitações estabelecidas à disponibilidade sobre o próprio corpo.

A questão cresce em complexidade se o paciente é criança ou adolescente, incapaz, portanto (ainda que em estado de consciência), de se autodeterminar e de expressar sua livre vontade de forma válida. Além de indagar o que, quando e como fazer, impõe-se verificar se o procedimento cabível 'pode' ser adotado, isto é, se o médico tem pleno poder de decisão ou se depende de autorização para adoção das práticas entendidas cabíveis. Os pais têm o poder para conceder tal autorização? Em qualquer caso? Para qualquer fim?

Considerado o princípio da beneficência, que deve orientar as práticas médicas, é de presumir-se que todas as medidas adotadas em relação aos pacientes sejam para o seu bem-estar. E com mais razão ainda em se tratando de pessoa menor de idade, em que 'todas' as ações, médicas ou não, devem estar voltadas para sua proteção. Portanto, surge a indagação: quem protege, quem defende os interesses da criança?

As breves considerações que se seguem possuem fundamento jurídico, tendo em vista o papel reconhecido ao direito de regulamentador, por excelência, das relações sociais, não só dirimindo conflitos, mas, igualmente, orientando condutas e mesmo promovendo novos comportamentos nessas relações.

A abordagem não compreenderá aspectos penais, em razão de escaparem à ambiciosa proposta do presente: contribuir, ainda que pela mera apresentação de pontos de reflexão, para a solução dos complexos problemas que emergem da relação médico-paciente, sendo a criança ou o adolescente matéria que ainda não mereceu a necessária atenção dos estudiosos do Direito.

Observe-se que a lei cuidou expressamente da proteção à vida e à saúde da criança, a ser atendida mediante efetivação de políticas sociais públicas que permitam o nascimento e o desenvolvimento sadio e harmonioso, 
em condições dignas de existência, assegurando cuidados à gestante, aleitamento materno e cuidados com o recém-nascido (ECA, 1990). Contudo, a proteção da criança já em desenvolvimento, especialmente no que diz respeito a sua saúde, está contida em cláusulas gerais que exigem a necessária interpretação.

\section{A Proteç̃o do lncapaz}

A lei brasileira, no que diz respeito à "capacidade natural de entendimento, inteligência e vontade própria da pessoa natural" (Amaral, 2003: 230), estabelece duas categorias de pessoas humanas: 1) as capazes, ou seja, as que podem agir por si próprias, gerenciando seu corpo e seus bens; 2) as incapazes, isto é, pessoas a quem a lei não reconhece o poder de se autodeterminar, por força de uma das causas indicadas pelo legislador, como idade ou doença, e que dependerão de outra que 'decida', 'fale' ou 'atue' em seu lugar - em outras palavras, que as represente ou assista até que cesse a causa da incapacidade.

Em função da causa e da menor ou maior possibilidade de consciência dos seus atos, a lei considera, respectivamente, absolutamente incapazes para os atos da vida civil: 1) os menores de 16 anos; 2) os que, por enfermidade ou deficiência mental, não têm discernimento para tais atos; 3) os que, mesmo por causa transitória, não possam exprimir sua vontade. Já os relativamente incapazes são: 1) os maiores de 16 e menores de 18 anos; 2) os ébrios habituais; 3) os toxicômanos; 4) os que, por deficiência mental, tenham discernimento reduzido; 5) os excepcionais, sem desenvolvimento mental completo (Código Civil, 2002).

$\mathrm{O}$ instituto da incapacidade tem por fim a proteção dos incapazes ou, como afirmava a lei civil anterior, a "proteção da pessoa e bem dos incapazes" (Lei 3071/16, 1916). Esta lei atribui a determinadas pessoas poderes sobre os incapazes, para que exerçam diretamente essa proteção. Tais poderes têm como fim e limite, portanto, o interesse do incapaz.

O exercício do poder de representação e assistência encontra-se regulamentado no Código Civil de 2002. A lei civil é razoavelmente clara no que diz respeito à gerência dos bens dos incapazes. O mesmo não se 
pode afirmar em relação à pessoa dos incapazes, ou seja, sobre o poder de interferência e decisão que se admite ao representante ou assistente em relação aos interesses não-patrimoniais do incapaz, inclusive seu corpo físico, sobressaindo as questões relativas à sua saúde.

Sob esse último aspecto, a matéria suscita acesa divergência, cujo exemplo é o problema da esterilização cirúrgica de mulheres alienadas mentais. Em alguns casos em que foi requerida autorização judicial para realização da cirurgia, visto reconhecer-se que a matéria é de alta indagação e não se inclui nos limites da representação, as decisões foram contrárias: no caso de portadora de esquizofrenia irreversível, que costumava fugir e retornar grávida, autorizou-se a cirurgia, entendendo-a como "remédio necessário para minorar o mal causado" - no caso, a gravidez (Tribunal de Justiça de São Paulo, 1988). Em outros dois casos, foi negada a autorização: no primeiro, por inexistir "amparo legal, moral ou científico para a pretensão de laqueadura das trompas da interdita" (Tribunal de Justiça do Rio Grande do Sul, 1997); no segundo, "por abrir um precedente perigoso e terrível", sob o fundamento de que o avanço da Ciência poderá mais tarde até curar a psicose de que padecia a mulher, que perderá a possibilidade de procriar, visto não haver garantia de reversão dos efeitos do ato cirúrgico (Tribunal de Justiça do Rio Grande do Sul, 1997).

Em todos os casos, sob diferentes argumentos, se objetivava proteger o interesse da mulher incapaz. Destaca-se, contudo, um aspecto comum: a intervenção no corpo da pessoa incapaz, por seus efeitos irreversíveis, ultrapassou o poder de decisão do médico e dos representantes legais dos pacientes, cabendo aos tribunais decidir. A divergência das decisões judiciais, tomadas com o mesmo objetivo - defesa dos interesses do incapaz -, demonstra a dificuldade de encontrar orientação adequada, em face da multiplicidade de fatores envolvidos.

A ação sobre o próprio corpo é matéria que tem posto em confronto os limites do consentimento livre e esclarecido, mesmo de pessoas capazes, visto que se questiona até que limite pode alguém dispor do próprio corpo, quer para fins terapêuticos e experimentais, quer meramente estéticos, aqui incluídas desde cirurgias plásticas, implantes diversos até tatuagens, 
para não se falar nas amputações voluntárias (voluntary amputation) (Geocities, 2000). Não se cogita, no momento, ações relativas à preservação ou ao prolongamento da própria vida, questão de alta complexidade que merece tratamento distinto.

No caso de pessoas incapazes, a afirmativa de que o seu representante ou assistente - do encarregado, portanto, da defesa dos seus interesses pessoais e patrimoniais - pode autorizar os procedimentos necessários para proteção revela-se de todo insuficiente, como visto no exemplo anteriormente citado.

Em relação ao tratamento, é razoável entender-se que seu poder se restringe aos procedimentos normais, indicados pelo médico como necessários ou convenientes à preservação da saúde da pessoa incapaz. A dificuldade reside em saber o que se deve entender por 'procedimentos normais'. É também razoável considerar, de modo geral, que os procedimentos de natureza irreversível, que impliquem supressão permanente de órgão, sentido ou função, bem como aqueles que acarretem risco de vida ou de comprometimento grave das aptidões vitais, da saúde mental, mutilação ou deformidade fogem à normalidade.

Nesse sentido, serve de exemplo a lei sobre a disposição de tecidos, órgãos e partes do corpo humano vivo para fins de transplante ou tratamento. A regra impede a disposição por pessoa juridicamente incapaz, exceção feita ao autotransplante, para o qual basta a autorização de um de seus pais ou responsáveis legais. Observe-se que a doação de medula óssea, admitida na forma da lei, por exceção, também aos juridicamente incapazes, desde que o ato não ofereça risco à sua saúde, exige, além do consentimento dos responsáveis legais, autorização judicial.

À evidência, devem ser tomados os procedimentos em caso de emergência ou urgência, destinados a salvar a vida do paciente ou mesmo evitar um dano maior à sua saúde física ou mental, em que há impossibilidade ou dificuldade de se obter a autorização do responsável legal pelo incapaz. Fora dessas hipóteses, a falta de autorização, quando necessária, poderá sujeitar o médico à responsabilização. 


\section{O Poder dos Pais: LIMITES}

A Constituição da República vigente incorporou, ao ordenamento jurídico brasileiro, a denominada doutrina da proteção integral, que se pode traduzir, em síntese, pelo atendimento ao princípio do melhor interesse da criança e do adolescente (Pereira, 2000), assegurando, com absoluta prioridade, direitos próprios à sua condição peculiar de pessoa em desenvolvimento (Oliveira, 1996). Entre esses direitos, inclui-se a saúde, devendo o Estado promover programas de assistência integral à saúde da criança e do adolescente.

De acordo com o Estatuto da Criança e do Adolescente (ECA, 1990), que dispõe sobre a proteção integral à criança e ao adolescente, considerase criança a pessoa até 12 anos incompletos e adolescente, o maior de 12 e menor de 18 anos. A lei, na linha da Constituição, além de assegurar a essas pessoas em desenvolvimento todos os direitos fundamentais inerentes à pessoa humana, determina que é dever da família, da comunidade, da sociedade em geral e do poder público assegurar, com absoluta prioridade, a efetivação dos direitos referentes à vida, à saúde, à alimentação, à educação, ao esporte, ao lazer, à profissionalização, à cultura, à dignidade, ao respeito, à liberdade e à convivência familiar e comunitária.

Os pais têm o dever constitucional de assistir, criar e educar os filhos menores (Oliveira, 1996), competindo-lhes representá-los até os 16 anos e assisti-los, após essa idade, até os 18 anos, momento em que se tornam plenamente capazes para todos os fins de direito (Código Civil, 2002).

Os pais exercem, com exclusividade e em igualdade de condições, o poder familiar, anteriormente denominado pátrio poder, sendo os representantes legais das pessoas menores de 18 anos. Havendo discordância entre os pais, qualquer um deles pode recorrer ao juiz para solução da divergência. Não havendo titular do poder familiar, por serem falecidos os pais ou por terem decaído do poder familiar, nos termos da lei, a representação dos menores deve ser feita por um tutor, nomeado pelo juiz.

Como ressaltado, a atuação do representante (ou assistente) dos incapazes, deve pautar-se pela guarda e defesa dos interesses pessoais e patrimoniais daqueles. No caso de criança e adolescente, há determinações 
constitucionais e legais específicas que não podem ser preteridas, ou seja, mesmo os pais devem observá-las.

Contudo, afirma-se, de modo corrente, que os pais têm 'direito' sobre seus filhos, visto caber-lhes o pátrio 'poder' - hoje poder familiar. Já se assinalou, com propriedade, que o senso comum costuma legitimar todas as ações paternas/maternas, presumidamente exercidas no interesse do filho, ainda que tais ações sejam violentas, visto serem as crianças e os adolescentes "detentores do privilégio da clarividência dos pais, definidores do que é melhor para seus filhos", compreensão essa que foi durante muitos anos assimilada pelas instituições públicas e privadas, redundando em um sistema cheio de "boas intenções" e lotado de "infernos" (Marques, 2000: 467). Esse entendimento de que os pais 'sabem tudo o que é melhor para os filhos' se mantém legitimando, ainda, desde regimes de educação repressivos e punições até o trabalho infantil, considerado 'educativo', quando não se encontram ambos conjugados.

O senso comum, no caso, deve ser de todo rejeitado e não encontra qualquer amparo no direito vigente. Na verdade, os pais são titulares de um 'poder jurídico' que se revela um conjunto de deveres. As faculdades ou 'poderes' sobre os filhos, que são legalmente atribuídos aos pais, têm o fim exclusivo de permitir ou facilitar o cumprimento desses deveres. Assim, os pais devem exercer o poder familiar exclusivamente no interesse do filho.

Caso exerçam esse poder em benefício próprio ou de modo prejudicial aos interesses pessoais ou patrimoniais do filho, seu poder pode ser suspenso ou até retirado. O melhor interesse do filho (Barboza, 2000) é a medida e o limite do poder dos pais e estará atendido à medida que sejam observados, pela família, pela sociedade e pelo Estado, os direitos que lhe foram constitucionalmente assegurados. As decisões dos pais quanto aos procedimentos a serem adotados com seus filhos devem ser respeitadas levando em conta essa nova compreensão do poder sobre os filhos.

\section{Responsabilidade do Médico}

A alteração de entendimentos também se fez sentir na atuação médica, que não ficou imune às profundas modificações socioculturais e 
tecnológicas ocorridas no último século, indicando-se um conflito de pelo menos três paradigmas nos códigos brasileiros de ética médica: o tecnocientífico, o comercial-empresarial e o benigno-humanitário (Martin, 2002).

Essa mudança decorreu, também, da crescente interferência dos direitos humanos nas relações médico-paciente, especialmente no reconhecimento dos direitos do paciente que acabou assimilado pelo Código de Ética Médica de 1988. Tem o doente, entre outros: 1) o direito de tornarse paciente; 2) o direito ao sigilo; 3) o direito à verdade; 4) o direito de decidir sobre seu tratamento e sua vida; 5) o direito de não ter seu tratamento complicado (Martin, 2002).

Nessa linha, estabelece o Código de Ética Médica (1988) ser vedado ao médico efetuar qualquer procedimento sem o esclarecimento e consentimento prévios do paciente ou de seu responsável legal, salvo iminente perigo de vida (art. 46). O médico também é impedido de exercer sua autoridade de maneira a limitar o direito do paciente de decidir livremente sobre a sua pessoa ou seu bem-estar (art. 48). Igualmente é vedado ao médico desrespeitar o direito do paciente de decidir livremente sobre a execução de práticas diagnósticas ou terapêuticas, salvo em caso de iminente perigo de vida (art. 56).

Pode-se identificar duas conseqüências diretas dessa nova orientação, que acabam por se imbricar: altera-se, em parte, a responsabilidade do médico e cresce a importância do consentimento livre e esclarecido, que assume o papel de pressuposto para os procedimentos médicos, salvo havendo risco de vida.

O médico que não observar o direito dos pacientes de decidir livremente, além de afrontar o Código de Ética Médica, está sujeito à responsabilização civil e, dependendo do fato e das circunstâncias, também penal e administrativa. Ao lado das causas normais que ensejam a responsabilização do médico, inscreve-se mais uma: a de agir, exceto nos casos de iminente perigo de vida, sem ou contra a vontade do paciente.

O médico, contudo, não fica submetido à vontade do paciente, pois, como já se esclareceu, o profissional da saúde pode, por razões éticas, 
valendo-se da denominada 'cláusula de consciência', opor-se aos desejos do paciente de realizar certos procedimentos, tais como técnicas de reprodução assistida e aborto, ainda que exista amparo legal ou deontológico para tais ações (Muñoz \& Fortes, 1998).

Para emitir um consentimento realmente livre e tomar sua decisão, o doente deve ter sido suficientemente esclarecido, em linguagem acessível a uma pessoa leiga, sobre o procedimento proposto pelo médico, a forma e o tempo do seu desenvolvimento, os desconfortos e riscos a se enfrentar, os possíveis benefícios ou malefícios, os métodos alternativos existentes, os custos etc. Enfim, tudo o que razoavelmente possa interferir na decisão, não sendo aconselhável adotar-se um padrão ante as inúmeras variáveis existentes (Muñoz \& Fortes, 1998).

É indispensável que o paciente seja capaz de compreender os esclarecimentos e de consentir. Juridicamente, em termos formais, em se tratando de criança ou adolescente, o consentimento será dado por seus representantes legais, normalmente pelos pais. Contudo, impõe-se observar que o ECA (1990) lhes 'deu voz', determinando expressamente em vários dispositivos que sejam ouvidos nas ações de seu interesse. Ainda que assim não fosse, os menores têm assegurados todos os direitos humanos, o que seria o bastante para tornar necessária sua manifestação de vontade.

Parece razoável a orientação no sentido de que, sempre que possível, se cumpra a regra do ECA, ou seja, que se ouça a criança ou o adolescente, respeitando sua vontade, desde que não agrave seu estado ou ponha sua vida em perigo. Em outras palavras, consideradas as condições pessoais do paciente menor (sua idade, capacidade de percepção e de cumprir as prescrições médicas), deve-se respeitar, o quanto possível e razoável, seu consentimento livre e esclarecido.

Já se assinalou, em estudo sobre o princípio da autonomia, que esta deva ser particularizada no caso dos adolescentes. Cita-se, como exemplo, a incorporação ao Código de Ética da noção de 'maioridade sanitária', embora de modo não expresso, possibilitando aos profissionais ocultarem informações a respeito de seus pacientes menores de idade a seus pais ou responsáveis legais, quando julgarem que os adolescentes tenham 
competência para decidir a partir de uma avaliação adequada de seus problemas de saúde, salvo quando a ocultação possa causar danos ao paciente (art. 103) (Muñoz \& Fortes, 1998).

Embora tal compreensão não seja, à primeira vista, adequada em se tratando de criança - ou seja, de menor de 12 anos -, não se deve afastar, sempre que possível, sua manifestação de vontade, principalmente para aferir seu real estado e suas necessidades, pondo-a, não raro, a salvo da 'clarividência dos pais' antes referida.

A avaliação das condições pessoais da criança e do adolescente, assim como o maior ou menor respeito à sua vontade, inclusive no que diz respeito ao sigilo, em face da vontade dos representantes legais, estão a cargo exclusivo do médico. O médico assume, desse modo, papel de grande relevo social: o de defensor da criança e do adolescente, de guardião de seus interesses e direitos. Este talvez seja um dos aspectos mais relevantes e delicados de sua responsabilidade.

\section{Conflito entre o Médico e os Pais}

Na prática, certamente haverá conflito entre a orientação médica e a dos pais. Se por um lado, como visto, os pais não 'dispõem' dos filhos segundo o que entendem que lhes seja melhor, por outro, o médico - ainda que no interesse do menor - deve agir com cautela, de modo a não ultrapassar os limites éticos e legais, sob pena de responsabilização.

Deve-se observar que em determinadas situações, como as referidas de início, que comprometem ou põem em risco a vida e/ou a integridade psicofísica do paciente, a decisão caberá ao poder judiciário. Tome-se como exemplo a necessidade de autorização judicial para tratamentos experimentais, mesmo que em busca de benefício para a criança ou o adolescente, que tenham esse tipo de comprometimento.

Em alguns casos, a solução encontra-se na lei, como a vacinação obrigatória das crianças nos casos recomendados pelas autoridades sanitárias. Não podem os pais, em regra, impedir a vacinação em tais casos. À evidência, poderão criar empecilhos de fato, não levando seus filhos aos locais de vacinação, mas se esses forem vacinados em ações 
coletivas - por exemplo, em escolas - não poderão os pais se insurgir e acionar os responsáveis pela vacinação, que terão agido francamente no melhor interesse pela criança.

Há outras hipóteses mais tormentosas, como a transfusão de sangue para crianças pertencentes a famílias cuja religião não admite tal procedimento, como testemunhas de Jeová. O que deve prevalecer é a decisão dos pais ou mesmo do próprio adolescente, no sentido de não admiti-la, ou a determinação médica que a entende necessária? Do mesmo modo, deve o médico acatar o pedido dos pais, no caso de hermafroditismo verdadeiro, e definir cirurgicamente o sexo da criança, ou aguardar seu crescimento, assegurando-lhe o direito de opção em face do sexo (ou do gênero) que estiver vivenciando? Questões como essas exigem exame específico, particularmente por colocarem em confronto outras garantias constitucionais, como a dignidade da pessoa humana, o princípio da liberdade de credo, também assegurado de modo expresso à criança e ao adolescente (ECA, 1990), e o direito à identidade, que inclui a opção sexual, escapando, portanto, dessas breves considerações.

Afastadas as hipóteses de maior complexidade, constata-se que a solução dos conflitos cotidianos deve ter como objetivo único o melhor interesse do paciente menor. A defesa desse melhor interesse compete aos pais ou representantes legais, mas também ao médico.

Deve-se observar que o ECA (1990) determina que sejam obrigatoriamente comunicados ao conselho tutelar da respectiva localidade os casos de suspeita ou confirmação de maus-tratos contra criança ou adolescente, sem prejuízo de outras providências legais. Na ausência ou inoperância do conselho tutelar, a comunicação deve ser feita ao ministério público ou ao próprio juiz responsável pela localidade. Mas não só nestes casos devem ser tomadas providências. Contundentes relatos de médicos testemunham a importância desse tipo de atuação. Além disso, dão um bom exemplo de atendimento à vontade da criança. Em um deles, um menino de um ano e dois meses chegou aos médicos apresentando infecções de repetição, sendo constatado em alguns meses que o mesmo sofria de doença congênita, que evolui com infecções de repetição até a morte. Não havia tratamento à 
época, mas as infecções poderiam ser atenuadas com medicação apropriada. Ocorreram seguidos períodos de internação e, por longo período, a criança ficou com cateter semi-implantado para alimentação parenteral domiciliar e sonda nasogástrica, que ficava permanentemente em seu nariz. "Nunca aceitou gastrostomia e o respeitamos". Os médicos assistentes evitavam também fazer procedimentos ou interná-lo "quando o time do seu coração jogava". Repentinamente, a criança desapareceu. Os pais não mantinham mais contato. Sem esperanças e cansados, haviam entregado o filho "nas mãos de Deus", nada mais fazendo. Os médicos, "após várias tentativas e com muito constrangimento", os ameaçaram com denúncia ao conselho tutelar por maus-tratos, caso não procurassem ajuda para o filho. A criança retornou pior, desnutrida e com severa infecção, que resultou na amputação de um pé. Mesmo assim, não houve melhora. Haviam passado cinco anos desde o primeiro atendimento. O menino faleceu (Kipper \& Clotet, 1998: 37-39).

Não há dúvida quanto a terem os médicos respeitado a vontade do paciente, ainda que criança. Também parece não haver dúvida quanto a terem minorado o sofrimento de seu pequeno paciente e de lhe terem proporcionado uma morte mais digna.

\section{CONCLUSÃO}

Após 15 anos da promulgação da Constituição Brasileira de 1988, parece ser tempo de efetivar, na medida do possível, os direitos ali consagrados. Esta efetivação se inicia pela compreensão do alcance de suas normas. No caso da criança e do adolescente, impõe-se reconhecer a nova feição das relações familiares, notadamente entre o menor e seus representantes legais. Mais do que isso, é imperativo que se compreenda que a defesa da criança e do adolescente é dever de todos e que a lei fornece os instrumentos para tanto. 


\section{RefERÊNCIAS BibLIOGRÁficAS}

AMARAL, F. Introdução. In: Direito Civil. Rio de Janeiro: Renovar, 2003.

BARBOZA, H. H. O Estatuto da Criança e do Adolescente e a disciplina da filiação no Código Civil. In: PEREIRA, T. S. (Org.) O Melhor Interesse da Criança: um debate interdisciplinar. Rio de Janeiro: Renovar, 2000.

BARBOZA, H. H. Princípios do biodireito. In: Novos Temas de Biodireito e Bioética. Rio de Janeiro: Renovar, 2003.

CÓDIGO CIVIL. Lei 10.406, 10 jan. 2002. São Paulo: Revista dos Tribunais, 2002.

CÓDIGO DE ÉTICA MÉDICA. Resolução CFM n. 1.246/88, 8 jan. 1988 (D.O.U. 26.01.88), 1988.

ESTATUTO DA CRIANÇA E DO ADOLESCENTE (ECA). Estatuto da Criança $e$ do Adolescente. Lei 8.069, 13 jul. 1990.

GEOCITIES. What kind of individual seeks voluntary amputation?, 2000. Disponível em: http://Www.geocities.com/starstranger_2000/ who.html. Acesso em: 14 jan. 2004.

KIPPER, D. J. \& CLOTET, J. Princípios da beneficência e não-maleficência. In: COSTA, S. I. F. et al. (Orgs.) Iniciação à Bioética. Brasília: Conselho Federal de Medicina, 1998.

MARQUES, M. T. S. Melhor interesse da criança: do subjetivismo ao garantismo. In: PEREIRA, T. S. (Org.) O Melhor Interesse da Criança: um debate interdisciplinar. Rio de Janeiro: Renovar, 2000.

MARTIN, L. M. Os Direitos Humanos nos Códigos Brasileiros de Ética Médica. São Paulo: Loyola, 2002.

MUÑOZ, D. R. \& FORTES, P. A. C. O princípio da autonomia e o consentimento livre e esclarecido. In: IBIAPINA, S. F. C. et al. (Orgs.) Iniciação à Bioética. Brasília: Conselho Federal de Medicina, 1998.

OLIVEIRA, J. Constituição da República. São Paulo: Saraiva, 1996.

PEREIRA, T. S. O 'melhor interesse da criança'. In: PEREIRA, T. S. (Org.) O Melhor Interesse da Criança: um debate interdisciplinar. Rio de Janeiro: Renovar, 2000. 
Bioética e SAúde

TRIBUNAL DE JUSTIÇA DE SÃO PAULO. Apelação 92.948-1, 14 abr. 1988. RT 630/87. Disponível em: http://www1.tj.rs.gov.br/jprud/ documento.php. Acesso em: 13 maio 2002.

TRIBUNAL DE JUSTIÇA DO RIO GRANDE DO SUL. Apelação 596210153, 6 ago. 1997. Disponível em: http://www1.tj.rs.gov.br/jprud/ documento.php. Acesso em: 13 maio 2002. 


\section{Ética em Pesquisa na Área MATERNO-lNFANTIL}

7

Marisa Palácios

Sergio Rego

Fermin Roland Schramm

INTRODUÇ̃̃O

Este artigo tem o objetivo de discutir alguns aspectos éticos relacionados à realização de pesquisas com seres humanos na área maternoinfantil. É importante assinalar que as análises aqui priorizadas não estão relacionadas ao caráter ou à moral do pesquisador. Considera-se, a princípio, a boa intenção, a seriedade e a competência técnica dos pesquisadores. O propósito das análises éticas de um protocolo de pesquisa não está relacionado com estas questões, mas à moralidade dos atos em si.

Tendo em conta a necessidade de ampliar a discussão estimulando a criação de uma cultura sobre o tema, optou-se por realizar uma breve introdução na qual é apresentada, de forma bastante sucinta, a regulamentação vigente no Brasil e dois temas de extrema relevância atualmente: o conflito de interesses e a política de duplo padrão proposta por organizações internacionais. Em seguida, serão consideradas algumas questões específicas do campo materno-infantil. Assume-se que os leitores não são especialistas no tema, tendo seu interesse relacionado à prática em pesquisas ou à participação em um Comitê de Ética em Pesquisas.

Até 1996, não havia uma regulamentação ética efetiva sobre a realização de pesquisas na área da saúde com seres humanos. Nos primórdios da prática médica no Brasil, essa regulação era uma atribuição implícita dos órgãos corporativos. Após a criação dos conselhos federais profissionais, 
o Estado delegou a eles a responsabilidade pelo controle do exercício profissional, incluindo aí a ética profissional. A realização de pesquisas estava também incluída. Mas, na verdade, os profissionais da saúde, em particular a corporação de médicos, estiveram submissos, em muitos momentos, à lógica do desenvolvimento científico, que procurava justificar a realização de muitas pesquisas em nome de sua cientificidade e de sua utilidade para o avanço científico, em detrimento, muitas vezes, de seu dever de proteger seus pacientes.

São inúmeros os exemplos de experiências com seres humanos, nos mais diversos países e nos mais diferentes períodos, que demonstraram a insuficiência do controle realizado apenas por pares corporativos. Assim, seguindo a tendência observada no mundo ocidental, após o fim da ditadura e com a promulgação da Constituição de 1988, o Brasil criou sua primeira regulamentação sobre Ética em Pesquisa, através da Resolução 01/88 do Conselho Nacional de Saúde (CNS).

\section{A Regulamentação Brasileira}

Esta primeira resolução do CNS procurou estabelecer as regras iniciais para apreciação dos aspectos éticos na pesquisa que envolve humanos. Sua abrangência, entretanto, era muito limitada e não ocorreram maiores debates antes de sua publicação. Assim, decidiu-se realizar uma ampla consulta à comunidade científica, de usuários da saúde, corporações e muitas outras organizações de representação de interesses e, em 1996, o conselho aprovou suas diretrizes e normas regulamentadoras de pesquisas envolvendo seres humanos. Essa resolução, a de número 196 de outubro de 1996, conforme consta de seu preâmbulo, insere-se no movimento que se inicia com o Código de Nüremberg de 1947, passa pela Declaração Universal dos Direitos Humanos de 1948, faz referência às regulamentações internacionais - como a Declaração de Helsinque e a da Organização Mundial da Saúde (OMS) - no intuito de recuperar a experiência fora do Brasil e, ainda, avançar no sentido da garantia da autonomia e proteção aos sujeitos da pesquisa, especialmente os vulneráveis. 
A Resolução 196/96 incorpora alguns princípios éticos da tradição hipocrática que foram sendo incorporados à discussão ética aplicada às pesquisas desde Nüremberg até o Relatório Belmont. Esses princípios associam-se mais freqüentemente ao chamado principialismo e são: 1) o respeito à autonomia dos sujeitos da pesquisa; 2) beneficência (a pesquisa deverá beneficiar os sujeitos que dela participam); 3) não-maleficência (minimização de todo e qualquer risco de dano aos sujeitos da pesquisa); 4) deverá ser justa, socialmente relevante, tanto no sentido de ter repartido os benefícios que a pesquisa poderá oferecer - de acordo com a necessidade dos grupos populacionais - quanto no sentido de proteger os mais vulneráveis quando há possibilidade de se obter os mesmos resultados em pessoas com capacidade de entendimento e autonomia plena, ou sujeitas à coerção, como estudantes e militares.

Esses princípios devem ser considerados válidos de acordo com o contexto pertinente de cada caso específico, sem que haja primazia obrigatória de um sobre os outros, podendo, portanto, serem vistos como deveres imperfeitos ou prima facie.

Considere-se - como exemplo para reflexão - um projeto de pesquisa para testar a eficácia e segurança de um medicamento. Se o princípio da não-maleficência fosse um dever absoluto, os efeitos adversos dos medicamentos impediriam a realização da pesquisa.

Nem mesmo o princípio da autonomia ou do dever de se obter o consentimento esclarecido de qualquer sujeito, objeto de pesquisa, pode ser considerado absoluto, quando se suponha, por exemplo, o caso de pesquisa para determinar a prevalência e distribuição da infecção pelo HIV no Brasil, e tomando alíquotas anônimas de sangue a partir de material que seria desprezado em laboratórios. Seria possível argumentar que, embora o princípio da autonomia tivesse sido desrespeitado, a pesquisa poderia aumentar a eficiência das políticas direcionadas ao controle da infecção no Brasil com a disponibilização de dados que, de outra forma, seriam inviáveis de se obter. Esta impossibilidade (ou insuficiência) permite que outros princípios possam (ou devam) ser considerados na tomada de decisão. Em suma, esses princípios seriam necessariamente negociados a cada caso, 
na análise de cada projeto de pesquisa, já que não correspondem a deveres absolutos. Afirmando isso, quer-se ressaltar que, na análise dos projetos, é preciso considerar sempre os princípios ou deveres morais de forma contextualizada.

Analisar os aspectos éticos de um protocolo de pesquisa não é uma atividade que possa ser considerada como restrita a Comitês de Ética em Pesquisa (CEPs), criados sob a orientação da Resolução 196/96 em todas as instituições que realizam pesquisas envolvendo seres humanos. Eles devem ser considerados, em primeiro lugar, pela equipe que o elabora, em seguida pelo CEP que o apreciará antes de seu início e pelo sujeito da pesquisa que julgará se quer ou não participar dela.

\section{O Princíplo da Alutonomia (OU DO CONSENTIMENTO ESCLARECIDO) NA Resoluç̃̃o 196/96}

No Código de Nüremberg, em 1947, a questão do consentimento foi considerada da seguinte forma:

O consentimento voluntário do ser humano é absolutamente essencial. Isso significa que as pessoas que serão submetidas ao experimento devem ser legalmente capazes de dar consentimento; essas pessoas devem exercer o livre direito de escolha sem qualquer intervenção de elementos de força, fraude, mentira, coação, astúcia ou outra forma de restrição posterior; devem ter conhecimento suficiente do assunto em estudo para tomar uma decisão. Esse último aspecto exige que sejam explicados às pessoas a natureza, a duração e o propósito do experimento; os métodos segundo os quais será conduzido; as inconveniências e os riscos esperados; os efeitos sobre a saúde ou sobre a pessoa do participante que eventualmente possam ocorrer devido à participação no experimento.

É significativo lembrar que na Alemanha, desde o início do século XX, já havia uma regulamentação que demandava o consentimento dos 
indivíduos para que eles participassem de pesquisas. Isto fez com que as pesquisas realizadas pelos nazistas com seus prisioneiros ganhassem um significado ainda mais terrível, pois representava negar àqueles indivíduos sua própria condição humana reconhecida juridicamente.

A Resolução 196/96 refere-se ao consentimento afirmando que "o respeito devido à dignidade humana exige que toda pesquisa se processe após consentimento livre e esclarecido dos sujeitos, indivíduos ou grupos que por si e/ou por seus representantes legais manifestem a sua anuência à participação na pesquisa" (Brasil, 1996: capítulo IV). É importante notar que a expressão adotada pela resolução é "consentimento livre e esclarecido", enquanto no Brasil é muito freqüente que médicos, especialmente, utilizem equivocadamente uma tradução literal do inglês informed consent e se refiram a 'consentimento informado'. O equívoco está na impropriedade da aparente tradução literal. A palavra informed está associada não apenas a obter a informação, como também a entender essa informação. Já a palavra 'informado' está associada a uma comunicação em apenas uma direção, não pressupondo a compreensão da informação prestada, nem a sua anuência. Daí a propriedade com que os membros da comissão que prepararam a minuta da resolução tenham optado por referir-se ao consentimento como "livre e esclarecido".

O sujeito da pesquisa terá, portanto, de consentir em participar dela. Isso significa que tem de ser estabelecida uma relação entre pesquisador e sujeito da pesquisa de respeito e confiança mútuos. O pesquisador deverá considerar a linguagem que seja mais adequada ao entendimento do indivíduo. Não é aceitável o argumento de que o sujeito é incapaz de compreender o que se passa com ele e o que está sendo proposto como objetivos e métodos da pesquisa. Quando o pesquisador está convencido de que isso está ocorrendo, o caminho é usar a criatividade e mudar o estilo de comunicação para que o sujeito possa compreender o que está sendo proposto. Só então, depois de o pesquisador estar convencido de que o sujeito entendeu a pesquisa, deverá perguntar se ele aceita participar.

É preciso, também, levar em conta algumas situações especiais relacionadas às características dos sujeitos e ao contexto ou à natureza da 
própria pesquisa que influenciam ou atuam como limitadores da liberdade de escolher participar ou não da investigação. Conforme se verá adiante, as diferenças relacionadas ao contexto no qual a pesquisa se desenvolve têm sido usadas como argumento favorável ao uso de padrões éticos menos rigorosos em determinadas regiões do mundo, mas é também o caso das grávidas, das crianças, dos portadores de necessidades especiais etc.

\section{Os Princípios da BeneficênCIa e Não-Maleficência na Resoluç̃̃o 196/96}

O balanço crítico de riscos e benefícios é também um importante item da análise ética. Um levantamento exaustivo dos riscos potenciais, atuais ou futuros, é indispensável. Todos os riscos de dano a todas as dimensões do sujeito - física, psíquica, moral, espiritual - ou à coletividade onde está inserido devem ser contemplados. Os danos e os benefícios potenciais que precisam ser primeiramente considerados são os relacionados aos sujeitos diretamente envolvidos na pesquisa. Ponderados danos e benefícios para a população de sujeitos, diretamente envolvidos na pesquisa, é exigência ética "prevalecer sempre as probabilidades dos benefícios esperados sobre os riscos previsíveis" (Brasil, 1996: item III.3.d). Entretanto, não é possível deixar de considerar outros benefícios e danos que estão relacionados aos pesquisadores, à instituição onde se realiza a pesquisa ou ao patrocinador, visto que esses grupos, que estão necessariamente envolvidos na pesquisa, têm distintos interesses e podem influenciar, negativa ou positivamente, seu curso. A questão do conflito de interesses é um importante tópico que preocupa a comunidade científica mundial e, é claro, a população.

Não há pesquisa que seja isenta de risco. Ele sempre existe e pode ser imediato ou tardio e estar associado "às dimensões física, psíquica, moral, intelectual, social, cultural ou espiritual do ser humano, em qualquer fase de uma pesquisa e dela decorrente" (Brasil, 1996: item II.8). O primeiro passo para controlar os riscos é reconhecê-los. 


\section{O PRincípio da Justiça e A Resoluç̃̃o 196/96}

A Justiça como princípio norteador da análise ética de projetos de pesquisa se refere, nos termos da Resolução 196/96 (Brasil, 1996: item III. 1.d), à:

relevância social da pesquisa com vantagens significativas para os sujeitos da pesquisa e minimização do ônus para os sujeitos vulneráveis, o que garante a igual consideração dos interesses envolvidos, não perdendo o sentido de sua destinação sociohumanitária (justiça e eqüidade)

Nesse mesmo sentido, convém lembrar das pesquisas conduzidas no exterior que utilizam a população dos países periféricos sem, contudo, oferecer possibilidade de usufruir os benefícios do novo conhecimento produzido com a pesquisa. São exigências para que a pesquisa seja eticamente adequada:

assegurar aos sujeitos da pesquisa os benefícios resultantes do projeto, seja em termos de retorno social, acesso aos procedimentos, produtos ou agentes da pesquisa; assegurar aos sujeitos da pesquisa as condições de acompanhamento, tratamento ou de orientação, conforme o caso, nas pesquisas de rastreamento; demonstrar a preponderância de benefícios sobre riscos e custos. (Brasil, 1996: item III.3. p e q)

Além dos princípios que orientam a análise dos aspectos éticos da pesquisa, a resolução tornou obrigatória a análise de todo projeto de pesquisa por um CEP. Antes do primeiro sujeito da pesquisa ser abordado para participar da investigação, o CEP da instituição de pesquisa, à qual o projeto está vinculado, precisará ter aprovado o projeto. Para apreciação, o projeto tem de ser apresentado com todos os dados relevantes, desde os detalhes do processo de recrutamento - inclusive o modelo de termo de consentimento que será utilizado - até os objetivos, a metodologia e os resultados esperados, articulados de forma coerente. Um projeto só será factível após uma avaliação relevante, e depende, por exemplo, do orçamento e do 
financiamento, do consentimento da instituição, se a pesquisa será realizada em outra instituição ou se usará dados sob a guarda de outra instituição e de todos os elementos que deverão constar do corpo ou anexo ao projeto de pesquisa (Brasil, 1996).

\section{Resoluções Complementares}

Existem outras três resoluções particularmente relevantes para os que se dedicam a pesquisas na área materno-infantil: as Resoluções 251/97, 292/00 e 303/01 (Brasil, 1997, 2000, 2001). A primeira refere-se às pesquisas que envolvem novos fármacos, a segunda regulamenta as pesquisas conduzidas com financiamento do exterior e a terceira é sobre reprodução humana, a qual será abordada mais adiante. A Resolução 292/00 é extremamente importante no atual contexto de abusos sistemáticos contra as populações de países periféricos por pesquisadores de organizações ou indústrias localizadas em países centrais.

\section{O Duplo Padrão}

O duplo padrão é uma expressão que tem sido utilizada para designar, em diversas áreas, o tratamento diferenciado a países e culturas diferentes. Robert Cooper, ex-assessor do primeiro ministro Tony Blair, expressa o sentido da expressão no trecho que será reproduzido a seguir e que está disponível na íntegra no site do jornal britânico The Guardian:

Para o estado pós-moderno há, então, uma dificuldade. Nós precisamos nos acostumar à idéia de dois padrões (double standard). Entre nós mesmos, nós operamos com base em leis e em segurança cooperativa franca, mas ao lidarmos com tipos mais antiquados de Estado, nós precisamos reverter para métodos mais duros, característicos de uma era passada força, ataque preventivo, enganação, tudo que é necessário para esses que ainda moram em mundos característicos do século XIX, onde cada Estado cuidava de si. Um conselho para os estados pós-modernos: aqueles que têm vizinhos amigáveis, obedientes à lei, não deveriam se esquecer que em outras partes 
do mundo impera a lei da selva. Entre nós mesmos, nós mantemos a lei, mas quando nós estivermos operando na selva, nós também temos que usar as leis da selva. (Cooper, 2000: 37-38)

Essa idéia não é utilizada apenas para sustentar as ações do Reino Unido e dos Estados Unidos no campo da dominação pela força de Estados Nacionais, mas aplica-se também ao campo da ética em pesquisa. Essa idéia tem sido usada para justificar a realização, em países periféricos, de pesquisas que não são eticamente aceitáveis em seus países de origem. Um exemplo muito divulgado foi o estudo realizado na Tailândia financiado pelo National Institute of Health (NIH) dos Estados Unidos e que previa oferecer aos participantes da pesquisa (mulheres grávidas infectadas com o HIV) tratamento inferior ao padrão para prevenir a transmissão vertical, sob a alegação de que os países pobres não têm condições de oferecer o tratamento padrão pelo seu alto custo.

A reação internacional fez com que o debate fosse absorvido pela Associação Médica Mundial, que levou para sua assembléia a proposta de alteração de suas normas internacionais para pesquisa médica, conhecida como Declaração de Helsinque. A alteração, aparentemente sutil, propunha que, ao invés de assegurar o melhor método comprovado a todos os participantes da pesquisa, inclusive o grupo controle, fosse alterado para o melhor método disponível. Isso seria a consagração do duplo padrão: a possibilidade de realizar pesquisa em mulheres grávidas africanas infectadas com HIV utilizando até placebo, observar a história natural da Aids, como se dá a transmissão vertical na ausência de qualquer tratamento etc. Na proposta de revisão de 2000, o artigo 29 da declaração passou a ter a seguinte redação:

os benefícios, riscos, danos e efetividade de um novo método devem ser testados contra os atuais melhores métodos profiláticos, diagnósticos e terapêuticos. Isso não exclui o uso de placebo ou não-tratamento em estudos onde não há métodos profiláticos, diagnósticos e terapêuticos comprovados. (World Medical Association, 2000) 
Já a assembléia de 2002 tentou flexibilizar um pouco mais o uso do placebo agregando uma nota ao citado artigo, considerando-o aceitável nos casos de exigências metodológicas para determinação da eficácia e segurança e quando o risco de dano for considerado muito pequeno. Embora ainda não seja possível afirmar que há consenso internacional para a aprovação do duplo padrão e outras flexibilizações, está claro que tem havido um esforço grande de diversos pesquisadores em todo o mundo no sentido de flexibilizar por razões, real ou supostamente, pragmáticas. E a pressão tem sido aparentemente eficaz, visto que os padrões éticos preconizados estão cada vez menos rigorosos.

Em 2002, o Nuffield Council on Bioethics, que é uma organização com um corpo independente que examina questões éticas suscitadas pelo desenvolvimento da Biologia e da Medicina, publicou o livro The Ethics of Research Related to Healthcare in Developing Countries. A diretiva da Nuffield para pesquisas em países em desenvolvimento é que:

o padrão apropriado de cuidado a ser oferecido a participantes do grupo controle no projeto de pesquisa só pode ser definido em consulta com os que trabalham dentro do país no qual a pesquisa será realizada. Deve, então, ser justificado aos comitês de éticas de pesquisa pertinentes. (Nuffield Council on Bioethics, 2002)

Em outra parte, o documento afirma que nos cuidados médicos oferecidos ao sujeito de pesquisa:

onde quer que seja apropriado, deve ser oferecido aos participantes do grupo controle um padrão universal de cuidado para a doença que está sendo estudada. Onde não seja apropriado oferecer tal padrão, o mínimo que terá que ser oferecido é a melhor intervenção atualmente disponível como parte do sistema de saúde pública nacional. (Nuffield Council on Bioethics, 2002 - grifos nossos)

Com o argumento de assegurar o respeito à autonomia dos sujeitos de pesquisa e investigadores de países em desenvolvimento, este texto procura justificar o duplo padrão. Na realidade, como Schramm e Kottow (2000) já assinalaram, não se pode falar sobre dois padrões porque só 
existe um padrão válido (o paradigma), caso contrário não é um padrão. De acordo com esses autores, pode-se admitir - para exercício mental que dois (ou mais) paradigmas competitivos existam, caracterizando o que Thomas Kuhn (1992) chamou de crise do paradigma existente. Mas, neste caso, alguém deveria justificar, com argumentos cogentes, por que a referência a um paradigma do único padrão é válida para países desenvolvidos e a outra (com dois paradigmas competitivos) seria válida para pesquisas em países periféricos. Isto é, certamente, possível - devido a relações de força e de poder - mas não é, sem mais, moralmente legítimo.

De facto - mas não de iure - duas idéias básicas sustentam a adoção de padrões éticos inferiores em países periféricos: 1) que as pesquisas conduzidas pelos países centrais são realizadas em benefício do país hospedeiro; 2) os sujeitos da pesquisa e os pesquisadores dos países periféricos estão em condições de exercer plena autonomia. Nem a primeira nem a segunda idéia podem ser aceitas como verdadeiras.

Quanto à primeira assertiva, não se pode esquecer de que se está falando de um mundo globalizado, com relações de dependência e poder ainda fortemente concentrados. Um mundo globalizado onde a divisão internacional do trabalho em pesquisas biomédicas tende a reservar aos países periféricos o papel de objetos de pesquisas. Neste contexto, a decisão sobre o foco de pesquisas desenvolvidas nos países periféricos tem de expressar os interesses e as características da população, da comunidade científica e do Estado, ou seja, aqueles que tomam a decisão sobre onde investir terão de ser autênticos representantes do país onde se realiza a pesquisa. Em suma, não se pode compactuar com a visão de desenvolvimento presente desde as grandes navegações, que escravizou e dizimou populações nativas das mais variadas partes do mundo, e que continua presente nas guerras de hoje, acreditando que a humanidade, naturalmente, caminha para um mesmo padrão de desenvolvimento e que os países desenvolvidos têm a 'responsabilidade' de fazer com que os 'menos desenvolvidos' cheguem também ao mesmo ponto, nem que para isso seja necessária a guerra. Esse tipo de visão não passa de uma pífia justificativa para a subjugação dos povos aos interesses dos assim chamados "países centrais", cujo conceito 
contradiz, de fato, a própria idéia de globalização quando entendida como uma estrutura em rede sem nenhum centro a priori. E é assim também no desenvolvimento científico relacionado à saúde.

Quanto à segunda assertiva, para que se possa pensar a respeito da autonomia, é preciso que tanto os sujeitos da pesquisa quanto os pesquisadores dos países periféricos sejam aceitos como seres humanos em princípio autônomos. Nesse sentido, é inaceitável pensar que possa ser considerado apropriado oferecer menos do que o tratamento padrão, a não ser que possa ser aceita a idéia de que existam seres humanos de "segunda classe" ou seres humanos que não merecem cuidado e respeito (habitualmente dado nos países de origem deles) por causa de uma suposta condição de inferioridade, ontológica ou contingencial que seja.

Se, então, são todos, por princípio, pertencentes ao grupo dos humanos, os quais possuem, inclusive, seus direitos uniformizados na Declaração de 1948, ainda assim o contexto impõe condições para o real exercício da autonomia. Com efeito, em países onde há miséria e grande escassez de recursos para políticas públicas, os sujeitos envolvidos em pesquisa (e também os investigadores) são vulneráveis e têm capacidade limitada para exercer sua autonomia de forma plena. Por exemplo, um pesquisador, diante da possibilidade de ver seu programa de pesquisas financiado por organismos internacionais, estará em condições de pensar com clareza e isenção nos interesses da população para a qual presta serviços de saúde? Isso leva a outro ponto que será abordado: o conflito de interesses.

\section{O Conflito de lnteresses nas Pesquisas}

Conflito de interesses é uma situação de um conjunto de condições nas quais o julgamento de um profissional relativo a um interesse primário tende a ser, indevidamente, influenciado por um interesse secundário (Thompson, 1993). Como interesse primário do pesquisador tomamos a garantia de proteção dos sujeitos da pesquisa, em primeiro lugar. Por interesse secundário, é entendido qualquer tipo de interesse que possa afetar a prioridade lexical do interesse primário. Esse é um ponto de discussão importante, cada vez mais presente no cenário mundial. 
Considerar as condições em que interesses secundários possam influenciar o julgamento de profissionais não quer dizer que sejam as condições em que a maior parte dos profissionais agiria de forma inadequada, mas sim que, nas condições em exame, alguém poderá agir inadequadamente. Não se trata de um exame da casuística ou do caráter do agente, mas da análise das situações concretas de realização das pesquisas identificando quais são aquelas situações nas quais o interesse de proteger os sujeitos da pesquisa poderá estar ameaçado. Visto desta forma, a identificação de situações de conflito de interesses é importante para a proteção dos sujeitos da pesquisa e também dos pesquisadores. Alguns exemplos de fatos efetivamente ocorridos poderão mostrar melhor esta questão.

\section{Caso l: o caso da consulta ginecológica}

M., em visita à sua ginecologista com queixa de alteração do ciclo menstrual, obteve uma caixa de remédios que julgou ser amostra grátis. Sua médica orientou-a que tomasse aqueles comprimidos segundo a posologia que indicara. Não obtendo melhora, inclusive com a aparição de dismenorréia intensa, $M$. entrou em contato algumas vezes com a ginecologista, que a orientou continuar o tratamento até completar dois meses, quando então a veria novamente em seu consultório. Na segunda visita, M. foi solicitada a interromper o uso do medicamento oferecido. A ginecologista preencheu um formulário com as queixas de M.

Este caso apresenta um fato comum: o profissional está participando de um ensaio clínico, toma as decisões coerentemente com o protocolo de pesquisa e sequer informa ao paciente em que circunstância está prescrevendo determinado medicamento, nem seu caráter experimental. O conflito de interesses é facilmente observado quando se reconhece que o bem-estar da paciente em questão não foi considerado para que o protocolo fosse cumprido. Entretanto, a orientação de que o interesse primário do pesquisador deve sempre ser o bem-estar do sujeito da pesquisa está expressa não apenas nos códigos de ética profissional como na própria Declaração de Helsinque da Associação Médica Mundial, que afirma: “2. 
É dever do médico promover e salvaguardar a saúde da população. A consciência e o conhecimento do médico são dedicados ao cumprimento desse dever" e "5. Em pesquisa médica em humanos, considerações relacionadas ao bem-estar dos humanos têm precedência sobre os interesses da ciência e da sociedade" (World Medical Association, 2000).

\section{Caso 2: o caso de Nancy Olivieri, do HOSPITAL FOR SICK CHILDREN, DA UNIVERSIDADE DE TORONTO, CONTRA} A EMPRESA FARMACÊUUTICA APOTEX

Caso de grande repercussão no Canadá, inclusive com manifestações na grande imprensa, no qual a pesquisadora sofreu diversos constrangimentos, inclusive a perda de seu cargo de pesquisadora - depois recuperado -, porque resolveu informar seus pacientes de um caso de efeito adverso. A empresa alegou que, por força da cláusula de confidencialidade no contrato assinado pela pesquisadora, ela estaria obrigada a não revelar nada que ocorresse no curso da pesquisa. Ela foi acusada de má-conduta pela Apotex (Somerville, 2002).

Este exemplo mostra que a relação com a indústria é desigual, pois, apesar de não ter havido malefício para os sujeitos da pesquisa, a situação vivida pela pesquisadora poderia ter resultado em má pratica, caso ela omitisse informações de seus pacientes. De fato, há interesses distintos entre a empresa financiadora e os pesquisadores, e é preciso que todos os envolvidos estejam muito atentos para que os interesses da indústria e seu poder econômico não imponham ao pesquisador interesses que entrem em conflito com a garantia de proteção devida aos sujeitos da pesquisa. Particularmente, o Comitê de Ética em Pesquisa - que é o parceiro do pesquisador no que se refere ao interesse de garantir o bem-estar dos sujeitos da pesquisa - tem de estar atento para identificar e evitar situações como as dos dois exemplos.

Diversas são também as vozes que expressam preocupação com o conflito de interesses, principalmente quando o assunto é teste de 
medicamentos. A Dra. Marcia Angell, num editorial do New England Journal of Medicine escreve: "Mas confiar na indústria farmacêutica para avaliação não enviesada de seus produtos faz tanto sentido quanto confiar na indústria de cerveja para ensinar-nos sobre alcoolismo. O conflito de interesses é óbvio" (Angell, 2000: 509).

O Dr. Jerome Kassirer, num recente editorial do The Journal of the American Medical Association (JAMA), também escreve:

diretores de Escolas Médicas e programas de treinamento precisam fazer um bom trabalho para lidar com o conflito de interesses. Onde a preocupação for o profissionalismo, eles precisam ensinar que não existe almoço grátis. Nem jantar grátis. Nem livros. Nem mesmo uma caneta esferográfica. (Kassirer, 2001: 2.156)

Als-Nielsen et al. (2003) realizaram uma revisão de 370 relatórios de ensaios clínicos farmacológicos citados nas revisões publicadas na Cochrane Library. Entre os objetivos deste trabalho estava o de verificar se havia alguma relação entre a fonte financiadora da pesquisa e os resultados do ensaio clínico. Em relação a este tema, o estudo demonstrou que quando a pesquisa era financiada por uma entidade não-lucrativa havia uma maior probabilidade de não se comprovar a superioridade da droga experimental. Eles observaram que esse tipo de problema não estava necessariamente associado a erros na realização da pesquisa, mas na interpretação das tabelas que eles próprios apresentavam. Nesse sentido, recomendaram que os pareceristas fossem mais rigorosos na avaliação dos artigos submetidos para publicação para fazer seus autores observarem a coerência entre os resultados e as conclusões.

Os relatos apresentados dão conta das conseqüências quando o conflito de interesses se resolve pelo interesse secundário (com malefício para o sujeito da pesquisa - caso 1) ou pelo interesse primário (com malefício para o pesquisador - caso 2) ou quando resulta em distorções na publicação das conclusões dos estudos (como apresenta Als-Nielsen). Mostram, ainda, como os conflitos são gerados principalmente pela prática da indústria, 
quando financia diretamente os pesquisadores (Angell), ou através de ação insidiosa e sistemática durante a formação de profissionais (Kassirer).

O conflito de interesses está presente em grande parte das pesquisas, embora de forma muito significativa nos ensaios clínicos, possivelmente devido à forma de atuação da indústria farmacêutica. É preciso que os pesquisadores estejam atentos para essas situações, e que a relação entre CEPs e pesquisadores seja, de fato, de parceria. Muitas vezes, exatamente por força dos interesses secundários, o pesquisador não consegue enxergar a situação de conflito. É principalmente nesses casos que os CEPs são fundamentais: tanto porque estão de fora (são constituídos de forma independente) quanto porque seus olhares estão treinados para a observação dos aspectos éticos da pesquisa e os contextos que as envolve.

A identificação dos conflitos de interesse constitui o primeiro passo. A providência imediata é procurar evitar que a situação de conflito exista. Não sendo possível, é preciso evitar que os sujeitos da pesquisa sejam prejudicados e também evitar que os pesquisadores sejam prejudicados.

E quando há conflito de interesse? Podem estar presentes já no próprio CEP, quando não há independência. Por exemplo, quando o coordenador é o diretor da instituição ou seu principal pesquisador; ou quando é constituído exclusivamente por pessoal da saúde ou por funcionários da instituição ou, de maneira geral, por uma mesma categoria profissional, tendencialmente corporativa. Nesse sentido, são condições para evitar conflito de interesses presentes na Resolução 196/96 e complementares - a composição plural do CEP e a obrigatoriedade de incluir pelo menos um representante de usuários, não ter captação de recursos independente da instituição, trabalho nãoremunerado dos membros do CEP e a relação entre os CEPs e a Comissão Nacional de Ética em Pesquisa (Conep).

Quando os CEPs são constituídos de forma a garantir a pluralidade de enfoques (multiprofissionalismo), opiniões e interesses, com membros externos à instituição na qual se desenvolve a pesquisa e com representantes de usuários - isto é, quando funcionam regularmente e, inclusive, se preocupam com a formação de seus membros em Bioética -, eles estão via de regra em melhores condições para identificar situações 
de conflito de interesses. Essa identificação começa com a análise do projeto de pesquisa. Agora, há que se ter em conta que identificar os interesses envolvidos em um projeto de pesquisa não pressupõe julgamento de valor a priori, ou seja, não se pode, a princípio, valorizar negativamente o interesse da instituição de captar recursos através de pesquisa. De fato, conforme foi apresentado, todo projeto de pesquisa deve ser avaliado levando em conta todos os benefícios e danos possíveis: primeiro, dos sujeitos envolvidos na pesquisa, mas, também, é preciso que o balanço seja feito para cada um dos grupos identificados e envolvidos de alguma forma com a pesquisa, sejam organizações não-governamentais de pacientes, sejam a própria instituição e a empresa financiadora etc.

Assim sendo, é papel dos CEPs identificar as condições em que surgem interesses secundários capazes de influenciar o julgamento do profissional seja na condição de cuidador, seja naquela de pesquisador ou representante da instituição. E que interesses pode ter o pesquisador? Financeiros (diretos e indiretos - viagens, hotéis, almoços, presentes, entre outras vantagens), prestígio e interesses científicos (expostos anteriormente através de casos e citações). Os interesses da instituição também estão em jogo. É bastante sugestivo o caso do acordo da Novartis com a Universidade da Califórnia, Berkeley, em 1998. Foram 25 milhões de dólares em troca do:

direito de se apropriar de até um terço das descobertas feitas pelos pesquisadores do departamento [inclusive as financiadas pelo Estado da Califórnia ou pelo governo federal], assim como a concessão de negociar patentes das invenções decorrentes das pesquisas e do controle de duas das cinco cadeiras da Comissão de Pesquisa do Departamento de Microbiologia. (Warde, 2001)

Por último, o processo de reflexão sobre estas questões deve envolver não apenas pesquisadores, instituições de pesquisa e um sistema como aquele representado por CEP-Conep, mas especialmente os usuários, na medida em que a forma mais eficaz de garantir a proteção dos sujeitos da pesquisa (interesse primário) é seu próprio exercício do controle, seja 
diretamente exercendo a cidadania, através de seus mecanismos judiciais, seja através de suas organizações independentes do Estado.

\section{EsPeCIFICIDADE DO OBJETO}

Embora seja importante uma discussão genérica sobre ética e bioética em pesquisa, quando se debruçam sobre a temática da pesquisa na área materno-infantil, surgirão questões específicas. A especificidade da mulher e da criança tem merecido tanto de bioeticistas como de juristas reflexões e soluções particulares para este universo prático-discursivo. Com mais freqüência, essas questões relacionam-se com a discussão sobre a autonomia das crianças, a vulnerabilidade de crianças e adolescentes, as pesquisas em reprodução humana e na área da genética etc.

Por já estar sendo tratada em outros artigos desse livro, aqui será dado um enfoque mais específico na abordagem que as regulamentações brasileiras conferem. Nesse sentido, é importante ver, inicialmente, como a Resolução 196/96 define vulnerabilidade e a distingue de incapacidade:

II.15 - Vulnerabilidade - refere-se a estado de pessoas ou grupos que, por quaisquer razões ou motivos, tenham a sua capacidade de autodeterminação reduzida, sobretudo no que se refere ao consentimento livre e esclarecido.

II.16 - Incapacidade - Refere-se ao possível sujeito da pesquisa que não tenha capacidade civil para dar o seu consentimento livre e esclarecido, devendo ser assistido ou representado, de acordo com a legislação brasileira vigente. (Brasil, 1996: II.15 e 16)

Esta distinção expressa a diferença entre o aspecto ético (expresso no conceito de vulnerabilidade) e o aspecto legal (expresso na definição de incapacidade) que, em diversas situações, entram em conflito.

Considere-se uma pesquisa sobre aborto em adolescentes. A lei não os reconhece como tendo direito de decidirem por si e reclama que a autorização seja concedida pelos pais. Isto, entretanto, pode provocar graves danos às adolescentes que, eventualmente, não tenham relatado a situação de aborto para os pais. A alternativa para o respeito à lei e para não provocar 
danos está, por exemplo, em recorrer ao Conselho Tutelar. Agora, não é possível que a regulamentação ética seja entendida como uma receita de bolo, prescrevendo e condenando comportamentos ou ações, sem considerar aspectos relevantes, do ponto de vista moral, do contexto e que podem fazer com que a interpretação mude de forma significativa. Nesse sentido, o espírito da regulamentação, seu objetivo maior, é a proteção dos sujeitos de pesquisa em seus contextos concretos e é nesta perspectiva que ela deve ser lida e aplicada.

Em algumas situações, definir um indivíduo ou um grupo de indivíduos como 'incapazes' pode gerar algumas resistências em setores que defendem a autodeterminação desses indivíduos e grupos. Entendemos que o enquadramento como 'incapazes' é uma forma pertinente e legítima de caracterizar indivíduos ou comunidades cuja capacidade de defesa é frágil ou nula e que, portanto, devem ser objeto de proteção particular: como indivíduos com deficiência cognitiva acentuada ou indivíduos muito jovens. Poucas pessoas contestarão a incapacidade dos lactentes, mas o caso de pessoas de culturas diferentes, sobretudo minoritárias, merece a proteção do Estado, ainda que também deva ser respeitada a sua capacidade de, uma vez esclarecidas, tomarem suas próprias decisões de acordo com seus referenciais de valoração razoáveis e compartilháveis.

Assim, a Resolução 196/96 preconiza que as pesquisas devem ser realizadas, preferencialmente, em indivíduos com plena capacidade de tomar decisões, ressaltando que os indivíduos ou grupos populacionais vulneráveis ou incapazes também podem participar, desde que a participação na investigação possa trazer benefícios diretos a eles (Brasil, 1996: III.3.j).

Em relação às gestantes, esta resolução é também específica: “as pesquisas em mulheres grávidas devem ser precedidas de pesquisas em mulheres fora do período gestacional, exceto quando a gravidez for o objetivo fundamental da pesquisa" (Brasil, 1996: III.3.v). Outro cuidado relacionase à necessidade de realizar a avaliação de riscos e benefícios, levando em consideração as possíveis repercussões da participação na pesquisa sobre fertilidade, gravidez, bem-estar do embrião, feto ou recém-nascido, trabalho de parto, puerpério e lactação. 


\section{As Criancas também Devem Ser Ouvidas sobre a Participaç̃o em Pesquisas?}

Uma criança tem o direito de se recusar a participar de uma pesquisa? A partir de que idade a criança adquire este direito? Devemos acatar decisões de não participarem de uma pesquisa quando elas forem tomadas por crianças? E quando seus pais ou responsáveis legais tiverem concordado previamente?

Em 2000, realizou-se em Mônaco um simpósio sobre Bioética e os Direitos das Crianças no qual estes temas foram debatidos, concluindo-se que "[a] criança deve participar na tomada de decisões relativas tanto à sua saúde quanto à sua educação, de maneira crescente e mais qualificada, à medida que sua autonomia se afirmar. Cabe aos pais aceitar essa necessidade". Preconizou-se também que "quando houver diferença de interesses, o interesse da criança deve, em princípio, prevalecer sobre o do adulto" (Unesco e Associação Mundial dos Amigos da Criança, 2000).

A criança deve ter garantido o direito de ter suas questões como objeto do conhecimento científico, além do reconhecimento de sua especificidade como objeto de consideração moral. Com efeito, o avanço nas ciências biomédicas e humanas enfatiza agora as características próprias do organismo infantil, de forma que as pesquisas feitas com adultos não são necessariamente válidas para crianças. Assim, a população infantil, embora vulnerável, precisa que sejam realizadas pesquisas que atenderão às suas necessidades específicas. Em suma, por serem particularmente vulneráveis, as crianças precisam de especial proteção e não simplesmente de ser excluídas da pesquisa.

Qualquer avaliação para tomada de decisão na área da saúde que envolva criança deve levar em consideração seu processo de desenvolvimento, e, portanto, suas necessidades especiais e as conseqüências específicas dos procedimentos realizados. O que é benefício para a criança é o que melhor promova seu desenvolvimento para tornar-se uma pessoa autônoma, autosuficiente e capaz de desenvolver suas potencialidades, tornando-a, portanto, capaz de se 'auto-proteger'. Assim, é importante considerar, na 
análise dos riscos e no reconhecimento dos possíveis danos que possam ser provocados nas crianças, as repercussões em seu desenvolvimento físico, cognitivo, psicológico, moral e espiritual, condição necessária de ela se tornar autônoma.

Então, quem deve decidir sobre a participação das crianças em pesquisas? Quem deve tomar a decisão? É suficiente acreditar que os pais ou tutores decidem, acreditando serem as suas opções as que melhor preservam os interesses da criança?

Kopelman (1995a) assinala que existem quatro diferentes abordagens sobre o envolvimento de crianças com pesquisas. Na primeira, há uma pessoa plenamente autônoma que toma decisão em substituição à criança. Enfatiza-se a idéia de que os pais ou tutores têm autoridade moral e legal, sabem o que é melhor para a criança e, portanto, não há diferença entre a pesquisa realizada com crianças ou outras populações, bastando, assim, que sejam cumpridas as demandas éticas gerais. A segunda abordagem propõe que nenhuma criança pode ser envolvida em projeto de pesquisa, uma vez que não tem autonomia. É a chamada abordagem de Nüremberg. A terceira é a abordagem de Helsinque, que só admitiria a participação de crianças em pesquisas no caso de haver um benefício terapêutico imediato. E, por último, a quarta abordagem preconiza que deve ser levado em consideração o balanço crítico de riscos e benefícios.

É nessa última abordagem, em um mistura com a terceira, que tem se situado a regulamentação brasileira, segundo a qual nem é possível delegar aos pais toda a responsabilidade pela participação da criança na pesquisa, nem é possível estabelecer, a priori, de que tipo de pesquisa a criança pode participar. O caminho proposto é que, antes de a criança ser consultada e/ou dos pais ou tutores autorizarem, deve-se realizar uma cuidadosa e criteriosa avaliação de riscos e benefícios diretos pela equipe de pesquisa. Ainda antes de qualquer contato com a população envolvida, um CEP deve realizar sua análise da pesquisa considerando, com o mesmo cuidado e atenção, as condições que fundamentaram a equipe na tomada de decisão de realizá-la. 
Considere-se o caso descrito por Nascimento (2002) em uma reportagem que venceu um prêmio internacional sobre jornalismo científico. O jornalista descreve uma pesquisa realizada com crianças por um conceituado médico de Belo Horizonte, na qual foram induzidos ataques de asma nas crianças e uma parte da população estudada recebeu apenas placebo (uma substância que não provoca qualquer efeito no organismo, embora seja visualmente semelhante ao medicamento que está sendo testado). Este mesmo médico, segundo a reportagem, estava desenvolvendo a mesma pesquisa com menores de dois anos. A mãe de um bebê usado na pesquisa relatou que ele ficou cansado e com a respiração pesada no dia do teste com indução de um ataque de asma. E que também 'chiou' bastante, se assustou e chorou.

Estas pesquisas relatadas são exemplos claros de estudos que não respeitam a regulamentação brasileira e internacional sobre ética em pesquisa, já que não há benefício direto para as crianças, os riscos não são desprezíveis e o uso de placebo não deveria ter sido feito, já que existe tratamento conhecido (ou comprovado) e disponível para a crise asmática. De forma alguma as exigências éticas foram atendidas e é lamentável que ninguém - nem a Sociedade de Pediatria, nem o Conselho Regional de Medicina, nem a Procuradoria da República, nem os editores científicos das revistas onde os estudos foram divulgados - tenha resolvido considerar a afronta ao bem-estar das crianças que representaram estas pesquisas.

A Resolução 251, de 1997, que regulamenta pesquisas com novos medicamentos, estabelece que "quando se tratar de sujeitos cuja capacidade de autodeterminação não seja plena, além do consentimento do responsável legal, deve ser levada em conta a manifestação do próprio sujeito, ainda que com capacidade reduzida [por exemplo, idoso] ou não desenvolvida [por exemplo, criança]" (Brasil, 1997: IV.1.q).

\section{A Mulher como Sujeito de Pesquisa}

Há um debate internacional intenso sobre a autonomia e vulnerabilidade das mulheres objetos de pesquisa. Até o início dos anos de 
1990, evitava-se muito a inclusão de mulheres como objetos de pesquisa até que, neste período, surgiu nos Estados Unidos um movimento que defendia sua inclusão. Argumentava, apropriadamente, que as mulheres possuem uma especificidade biológica que precisa ser estudada e, particularmente nos ensaios clínicos de teste de medicamentos, precisavam ser especificamente avaliadas suas interações com o metabolismo das mulheres. Em 1993, com o NIH Revitalization Act foi determinado que as mulheres "têm que ser incluídas em todo projeto de pesquisa biomédica ou comportamental apoiado pelo $N I H$, salvo se houver uma clara e forçosa razão e justificativa [contrária]". Estas diretrizes acrescentam que o "custo não é uma razão aceitável para a exclusão" e que "mulheres com potencial para engravidar não podem ser rotineiramente excluídas da participação em pesquisa clínica" (Wilson, 1995).

As razões que fundamentaram a luta pela inclusão das mulheres como objetos de pesquisa são bem explicitadas por Kopelman (1995b), que defendeu a possibilidade de ser uma injusta negação de benefício estabelecer que as mulheres não possam ser sujeitos de pesquisa. Aqueles que, em geral, se manifestam contrários à inclusão de mulheres em pesquisas apresentam, como argumento principal, o fato de as mulheres poderem estar sujeitas a efeitos teratogênicos. Mas este é um argumento insuficiente, não apenas por privá-las dos benefícios específicos que as pesquisas de teste de medicamentos podem oferecer-lhes, mas porque os homens também estão sujeitos ao risco de efeitos teratogênicos. Essa mesma autora ainda se refere ao consenso, expresso nos guias internacionais do Council for International Organizations of Medical Sciences (Cioms) desde 1993, que considera que, quando há conflito em termos de necessidades de saúde entre mãe e feto, a mulher deve ter liberdade para tomar ela própria a decisão (Kopelman, 1995b; Cioms, 2002). Em suma, gravidez e a maternagem não tornam a mulher incapaz de dar seu consentimento como é, ao contrário, o caso de crianças - nem, muito menos, vulnerável à coerção ou manipulação, como estudantes ou prisioneiros.

Outra questão comum ao debate em torno da participação das mulheres em pesquisa é também a inclusão da perspectiva de gênero em 
todos os passos da pesquisa. São importantes os estudos que procuram conhecer as conseqüências psicológicas e sociais das intervenções em pacientes com câncer de mama, por exemplo. Qual o significado dessas mutilações terapêuticas para as mulheres?

Ao lado da preocupação com o fato de não excluir, o movimento feminista no Brasil tem colocado a questão da necessidade dos estudos do ponto de vista da abordagem de gênero e tem salientado a necessidade de proteger as populações das crescentes demandas, nem sempre eticamente adequadas, da indústria farmacêutica e do 'colonialismo científico', isto é, da importação, aceitação e aplicação acrítica e descontextualizada de modelos 'importados', sem uma avaliação ponderada de suas possibilidades de aplicação em nossa realidade específica. Assim sendo, alguns temas especiais para a população feminina precisam de mais discussão no campo da ética em pesquisa. A reprodução assistida e a genética são dois desses temas que serão abordados a seguir.

\section{Reproduç̃o Assistida}

A Resolução 196/96, quando foi assinada, estabeleceu algumas áreas especiais que demandaram resoluções específicas. O campo da reprodução humana foi um desses temas e resultou na Resolução 303, de 2000. Esta resolução definiu a abrangência de sua regulamentação como sendo referente às pesquisas "que se ocupam com o funcionamento do aparelho reprodutor, procriação e fatores que afetam a saúde reprodutiva da pessoa humana" (Brasil, 2000). Estabeleceu que as pesquisas relacionadas à reprodução assistida, anticoncepção, medicina fetal e manipulação de gametas, préembriões, embriões e feto devem ser analisadas pelo CEP que, depois de aprová-las, as encaminhará para apreciação da Conep, sendo que as pesquisas nas demais áreas da reprodução humana serão analisadas apenas pelo CEP.

Definiu também quem serão considerados 'sujeitos da pesquisa', neste campo, "todos os que forem afetados pelos procedimentos da mesma" (Brasil, 2000). No entanto, a despeito das boas intenções dessa formulação, 
está claro como ela é pouco precisa e, na prática, traz mais problemas do que ajuda. De fato, com esta definição, a resolução dá margem a que sejam pretensamente reconhecidos como sujeitos da pesquisa embriões ou mesmo pré-embriões, dependendo do que se opte por reconhecer como indivíduo ou pessoa. Em outros termos, esta concepção é pouco condizente com o espírito livre e moderno das regulamentações do Conselho Nacional de Saúde, parecendo ter sido influenciada por crenças religiosas que, em hipótese alguma, poderiam fundamentar políticas públicas em um Estado laico e democrático como o brasileiro.

\section{GenÉTICA}

A Instrução Normativa 9 da Comissão Técnica Nacional de Biossegurança (CTNBio) (Brasil, 1997) considera como pesquisa em seres humanos todo experimento de intervenção ou manipulação genética, sujeitando-os, portanto, ao preconizado pela Resolução 196/96. Neste momento, assiste-se à discussão sobre as pesquisas em genética sendo realizadas na sociedade e no Congresso Nacional. Ao que tudo indica, de acordo com o texto aprovado na Câmara dos Deputados que foi encaminhado ao Senado Federal, deve ser mantida a proibição da realização de pesquisas com células germinais.

De acordo com a referida instrução normativa da CTNBio:

todas as propostas de intervenção ou manipulação genética de humanos serão examinadas pela CTNBio, sob o prisma de dois riscos maiores do ponto de vista de biossegurança, a saber: (1) risco de transmissão horizontal da seqüência nucleotídica transferida ou do vetor a outras pessoas com quem o paciente tenha contato, e (2) risco de modificação inadvertida de células germinativas, com transmissão vertical das alterações genéticas à progênie do paciente. (Brasil, 1997)

As discussões sobre os limites a serem impostos aos pesquisadores no campo da genética costumam ser apaixonadas e, muitas vezes, pouco racionais. Existem dois argumentos principais daqueles que são contrários 
às pesquisas que possibilitem manipulações genéticas ou clonagens de seres humanos. O primeiro é fundamentado por uma perspectiva religiosa e baseia-se na inadequação da conduta humana em atuar como Deus (playing god, expressão que não aceita ser traduzida como 'brincar de Deus' - certamente uma das traduções possíveis do verbo to play -, mas que passa sob silêncio, de maneira sub-reptícia, a outra tradução, também possível e que se adota, por entender que a primeira não seria uma tradução imparcial, mas sim sobredeterminada conotativamente e tendenciosa, isto é, já incorporando valores que visam, de fato, a desqualificar qualquer intervenção transformadora).

As pessoas que adotam este ponto de vista também tentam fundamentar sua posição contrária a essas experiências fazendo referência a um conceito de pessoa (de origem inicialmente literária ou teatral, em seguida prevalentemente filosófica e, eventualmente, teológica) identificado com o conceito de ser humano (que, embora possa ser reelaborado filosófica e teologicamente, é, de fato, um conceito biológico referente à entidade Homo sapiens sapiens), considerados sinônimos perfeitos e, sobretudo, tendo em conta, sem mais, que um ser humano existiria 'potencialmente' desde os estágios mais primitivos do desenvolvimento do embrião, quando de fato as células ainda são passíveis de serem contadas com os dedos das mãos, ou mesmo desde a concepção. Agora, esta posição extremista é identificada como a posição oficial da igreja católica embora "o magistério eclesiástico não afirme absolutamente que o feto é pessoa" (Mori, 1997: 30), o que deveria, pelo menos, fazer refletir sobre a problematicidade desta identificação.

Outro grupo pretende utilizar como argumento o princípio da precaução, entendendo que não há segurança sobre quais seriam as possíveis conseqüências de clonagens e intervenções genéticas nas gerações futuras, muitas vezes interpretando-o como uma eqüiprobabilidade de riscos e benefícios, mas no sentido de que, nesta situação, seria necessário optar por privilegiar, talvez de acordo com uma interpretação 'pessimista' e conservadora da assim chamada lei de Murphy, pelo pior egresso. Entendido dessa forma, o princípio da precaução serviria como fundamento para a 
negação de boa parte das pesquisas científicas, para não se dizer da utilização de tecnologias em geral.

Considere-se, por exemplo, a utilização dos raios-X em procedimentos diagnósticos. É sabido que o excesso de raios-X no organismo pode favorecer até o desenvolvimento de neoplasias. Quem pode assegurar quais são as conseqüências da exposição profissional a esta radiação para o genoma de indivíduos que se reproduzirão e que podem estar transmitindo às futuras gerações uma bomba de efeito retardado sob a forma de uma mutação genética? No entanto, o 'espanto' frente ao desconhecido que, tradicionalmente, é tido como a razão ou o 'disparo' do começo do 'filosofar' na Grécia não pode ser reduzido ao mero medo do desconhecido, nem pode, sem argumentos adicionais, servir para impedir a pesquisa, podendo, em realidade, servir também como estímulo para o rigor científico e ético.

\section{Consideracões Finais}

Assim sendo, o verdadeiro desafio do momento é delimitar a discussão ao campo da ética laica, reconhecendo-a como o campo que possibilita os debates em torno de políticas públicas de forma racional e imparcial, pois se julga que este é o 'caminho' (ou o método) que permite melhor distanciarse seja do deslumbre, seja do medo, ambos acríticos frente ao possível e, eventualmente, desejável. Em suma, é auspicioso que, em sociedades complexas e secularizadas, como é possivelmente a brasileira, as convicções religiosas possam permanecer orientando as decisões dos que têm fé e aceitam as orientações de suas igrejas, mas deixando às políticas públicas um espaço respeitador das diferentes concepções sobre a vida e a fé, integrando-as no espírito republicano, isto é, deixando claro que as instituições, ainda que respeitem cada uma das crenças específicas, devem assumir uma postura também secular que separa as questões da Cidade Celeste daquelas da Cidade Terrena. O que não significa, evidentemente, deixar que a Ciência seja regulada por alguma 'ética do conhecimento' supostamente capaz per se de dizer o que deve ser feito; isto é, uma ética 
definida pela dinâmica interna ao próprio conhecimento capaz de determinar o rumo correto do agir (o que seria contrário à lei de Hume, que interdita derivar o que deve ser feito daquilo que é, isto é, inferir valores a partir de fatos) ou por qualquer ética endógena, própria de alguma comunidade específica - seja ela de tipo religioso ou profissional - capaz de impor ao imaginário social como um todo regras de conduta aceitáveis por crentes, agnósticos e ateus que queiram conviver respeitando-se reciprocamente. Em resumo, a regulação ética é da sociedade laica e democrática, a partir do reconhecimento das diferenças, do respeito a elas e da construção de consensos, ainda que provisórios, pois ela permite, em princípio, e para além de uma ética maximalista, encontrar meios para que cada um se respeite em suas diferenças, capacidades e, sobretudo, em sua vulnerabilidade, que, como tentamos mostrar, é, ainda, uma das características da condição do humano.

\section{ReFERÊNCIAS BiBliográfiCAS}

ALS-NIELSEN, B. et al. Association of funding and conclusions in randomized drug trials: a reflection of treatment effect or adverse events? The Journal of the American Medical Association (JAMA), 290: 921-928, 2003.

ANGELL, M. Is Academic Medicine for Sale? Editorial. New England Journal of Medicine, 343: 508-510, 2000.

BRASIL. Resolução 196/96: Aprova as diretrizes e normas regulamentadoras de pesquisas envolvendo seres humanos. Brasília: Conselho Nacional de Saúde, Ministério da Saúde, 1996. Disponível em: http:// conselho.saude.gov.br/docs/Reso196.doc. Acesso em: 15 mar. 2004.

BRASIL. Resolução 251/97: Aprova as normas de pesquisa envolvendo seres humanos para a área temática de pesquisa com novos fármacos, medicamentos, vacinas e testes diagnósticos. Brasília: Conselho Nacional de Saúde, Ministério da Saúde, 1997. Disponível em: http:// conselho.saude.gov.br/docs/Reso251.doc. Acesso em: 15 mar. 2004. 
BRASIL. Resolução 292/99: Aprova as normas de pesquisa envolvendo seres humanos para a área temática especial "pesquisas coordenadas do exterior ou com participação estrangeira e pesquisas que envolvam remessa de material biológico para o exterior", 1999 Brasília: Conselho Nacional de Saúde, Ministério da Saúde. Disponível em http:// conselho.saude.gov.br/docs/Reso292.doc. Acesso em: 15 mar. 2004, 1999.

BRASIL. Instrução Normativa n. 9 da Comissão Técnica Nacional de Biossegurança -CTNBio. Publicada do Diário Oficial da União - DOU n. 200, de 16 out. 1997, Seção 1, páginas 23487-23488. Disponível em: http://www.ghente.org/doc_juridicos/in09.htm. Acesso em: 15 mar. 2004, 1997.

BRASIL. Resolução 303/00: Aprova as normas de pesquisa envolvendo seres humanos para a área temática especial "reprodução humana". Brasília: Conselho Nacional de Saúde, Ministério da Saúde. Disponível em: http:/ /conselho.saude.gov.br/docs/Reso303.doc. Acesso em: 15/03/2004, 2000

COOPER, R. The postmodern State and the world order Demos Institute, 2000. Disponível em: http://www.demos.co.uk/uploadstore/docs/ postmodern_state.pdf. Acesso em: 15 mar. 2004.

COUNCIL FOR INTERNATIONAL ORGANIZATIONS OF MEDICAL SCIENCES (CIOMS). International Ethical Guidelines for Biomedical Research Involving Human Subjects. Geneve: CIOMS/WHO, 2002.

KASSIRER, J. P. Financial indigestion. The Journal of the American Medical Association $(J A M A), 284: 2.156-2.157,2000$.

KOPELMAN, L. M. Health-care and research issues. In: REICH, W. T. Encyclopedia of Bioethics. (Org.) CD-ROM. New York: Simon \& Schuster Macmillan, 1995a.

KOPELMAN, L. M. Risk and vulnerable groups. In: REICH, W. T. (Org.) Encyclopedia of Bioethics. CD-ROM. New York: Simon \& Schuster Macmillan, 1995b.

KUHN, T. S. A estrutura das revoluções científicas. Tradução de Beatriz Vianna Boeira e Nelson Boeira. 3.ed. São Paulo: Perspectiva, 1992. 
MORI, M. A Moralidade do Aborto. Brasília: UNB, 1997.

NASCIMENTO, S. Cobaias humanas. Jornal Correio Brasiliense, Brasília, 17 mar., 2002. Disponível em: http://www2.correioweb.com.br/cw/ 2002-03-17/mat_36742.htm. Acesso em: 15 mar. 2004.

NUFFIELD COUNCIL ON BIOETHICS. The ethics of healthcare-related research in developing countries, 2002. Disponível em: http:// wWw.nuffieldbioethics.org/publications/developingcountries/ rep0000000942.asp. Acesso em: 15 mar. 2004.

NÜREMBERG. Experimentação Humana. Código de Nüremberg, 1947. Conselho Nacional de Saúde, jan. 2004. Disponível em: http://conselho.saude.gov.br/docs/doc_ref_eticapesq/ C\%F3digo\%20de\%20Nüremberg.doc. Acesso em: 15 mar. 2004.

SCHRAMM, F. R. \& KOTTOW, M. Nuevos desafios para los comités de ética en investigación. Cuadernos Médico Sociales, XLI (1-2): 19-26, 2000.

SOMERVILLE, M. A. A postmodern moral tale: the ethics of research relationships. Nature Reviews: Drug Discovery, 1: 316-320, 2002.

THOMPSON, D. Understanding conflicts of interest. New England Journal of Medicine, 329: 573-76, 1993.

UNESCO \& ASSOCIAÇÃO MUNDIAL DOS AMIGOS DA CRIANÇA (AMADE). Declaração de Mônaco: Bioética e os Direitos da Criança. Mônaco: Simpósio Internacional sobre Bioética e os Direitos da Criança, 2000. Disponível em: http://www.ensp.fiocruz.br/etica/Docs/Outras/Biodc.rtf. Acesso em: 15 mar. 2004.

WARDE, I. A vampirização mercantil. Le Monde Diplomatique (edição brasileira), 2(14): mar. 2001. Disponível em: http://www.diplo.com.br/ aberto/0103/indice.htm. Acesso em: 15 mar. 2004.

WILSON, A. L. Research issues. In: REICH, W. T. (Org.) Encyclopedia of Bioethics. CD-ROM. New York: Simon \& Schuster Macmillan, 1995.

WORLD MEDICAL ASSOCIATION (WMA). World Medical Association Declaration of Helsinki: ethical principles for medical research involving human subjects. 2000. Disponível em: http://www.wma.net/e/policy/ pdf/17c.pdf. Acesso em: 18 nov. 2004. 


\title{
Bioética e Reproducão Humana
}

\section{8}

Marlene Braz

\begin{abstract}
A reprodução humana não é um ato consciente, nem é um ato voluntário e, sim, um acontecimento natural com suas causalidades e imprecisões, suas presumidas influências transcendentais (...) e suas bordas metafísicas (...)
\end{abstract}

Miguel Kottow

\section{INTRODUCC̃̃O}

A decisão de gerar uma criança não é um processo simples, abrangendo vários aspectos que vão desde os recursos financeiros da família até os de ordem emocional, espiritual e econômico-social. Por ser algo complexo que envolve inúmeras facetas e, principalmente, por tratar-se de um ato humano que envolve um outro ser humano a ser trazido ao mundo e que pode vir a ser fonte de conflitos, há necessidade de refletir, sob o ponto de vista bioético, muito mais que biologicamente, sobre as decisões que devem ser feitas frente à reprodução humana.

Com o objetivo de analisar o tema da reprodução humana e das implicações de que se reveste, será feita uma abordagem analítica, enfocando os seus subtemas, quais sejam: a questão da infertilidade, a anticoncepção, a reprodução dita natural e a medicamente assistida. Deve-se atentar que 
a reprodução humana não pode ser desvinculada de questões relativas ao início da vida, área repleta de conflitos éticos, mas que já foram tratadas em artigo desta coletânea. De qualquer modo, o conceito de início da vida humana deve atender e priorizar os valores dos diretamente afetados.

\section{A lnfertilidade e a Anticoncepcão}

A infertilidade, hoje considerada um problema de saúde, em épocas anteriores era vista como uma manifestação da vontade divina, não se admitindo a interferência dos humanos no processo de reprodução (Neto \& Júnior, 1998). Se, anteriormente, os humanos tinham de se conformar com o fato, atualmente, com as os avanços ocorridos neste campo, assistimos à possibilidade de uma não-aceitação deste quadro e a busca pela reversão de tal situação.

A infertilidade sempre existiu, podendo afetar um dos pares ou o casal e trazer implicações na vida conjugal, gerando, em muitos casos, conflitos e até separações. É fonte de sofrimento, angústia e, não raro, quadros depressivos. A mulher pode se sentir menos completa, menos feminina. Já os homens inférteis são identificados e se identificam como sendo pouco másculos (Neves \& Netto Júnior, 2003; Collucci, 2003).

O problema da infertilidade atinge de 8 a 15\% dos casais em idade reprodutiva (Diaz et al., 2002). No Brasil, a cifra chega a 10 milhões de pessoas em idade fértil, de acordo com o último censo do Instituto Brasileiro de Geografia e Estatística (IBGE) (Collucci, 2002). O número de pessoas atingidas é bastante elevado, constituindo-se, assim, num problema importante de saúde pública, dada a sua magnitude. Entretanto, a infertilidade de homens e mulheres pobres em nosso país não tem merecido a devida atenção por parte das políticas de saúde e, assim sendo, revestese de uma questão moral em função da falta de eqüidade no acesso aos serviços de saúde com vistas à prevenção ou ao tratamento.

Vários fatores contribuem para a infertilidade, tais como: 1) condições sociais precárias, como deficiência alimentar; 2) problemas de saúde ligados tanto a uma infertilidade congênita, como a uma infertilidade 
adquirida por seqüelas de abortos, infecções e doenças não tratadas do aparelho genital feminino; 3) postergação da maternidade, o que aumenta a infertilidade; 4) maior reconhecimento da infertilidade masculina; 5) impedimentos subjetivos de ordem inconsciente (Braz \& Castro, 2003).

Existem, de outro modo, causas de infertilidade que, em sua maioria, não se podem prevenir, tais como:

endometriose, doenças imunológicas (que produzem anticorpos contra espermatozóides ou óvulos), defeitos genéticos das células germinativas, diminuição na quantidade ou qualidade dos espermatozóides, pólipo endometrial, mioma submucoso etc. Também faz parte da prevenção a atenção instantânea aos casais que após um ano com atividade sexual regular, sem usar método contraceptivo, não conseguiram ter uma gravidez. (Macedo, 2004)

É importante frisar, no entanto, que se a infertilidade for assumida apenas como um problema médico a ser solucionado pela tecnologia, haverá um desvio de atenção das causas da infertilidade que podem ser prevenidas, como doenças sexualmente transmissíveis (DSTs), poluição, pobreza, trabalho insalubre, aditivos químicos, hormônios, dispositivo intra-uterino (DIU), infecção pós-parto e esterilização precoce de mulheres.

Medidas que possam prevenir a infertilidade devem ser tomadas, pois têm um maior impacto do que recorrer às técnicas de reprodução assistida ou mesmo à clonagem (Melo-Martín, 2002). Entre as causas produtoras de infertilidade apontadas e preveníveis, é importante ressaltar a esterilização de mulheres, processo tão difundido na sociedade brasileira:

A laqueadura tubária é um importante fator de infertilidade feminina. Cerca de uma em cada três mulheres que fazem laqueadura se arrepende. Este fato é importante, pois os critérios de inclusão destas mulheres devem ser rigorosos. Levando-se em consideração a existência de tantos bons métodos contraceptivos temporários, os definitivos deverão ser a última opção, pois gerarão infertilidade definitiva. (Macedo, 2004) 
A taxa de fecundidade das brasileiras passou de 6,28 filhos por mulher, em 1960, para 2,38 no ano 2000, o que representou uma diminuição de 62,1\%, de acordo com pesquisa do IBGE (Censo 2000). Esta redução deve-se, principalmente, à região Sudeste, em função de sua grande urbanização,

o que proporciona maior acesso aos meios contraceptivos e o que permite a inserção cada vez maior da mulher no mercado de trabalho - e ao aumento da esterilização feminina, sobretudo na década de 80, que passou a exercer um papel importante na limitação do número de filhos. (Hoje On Line, 2004)

A preferência pela esterilização, no Brasil, não é uma escolha e sim uma falta de opção. Com efeito, de acordo com pesquisa realizada pela Rede Feminista de Saúde, as mulheres negras têm acesso mais precário aos métodos anticoncepcionais e, também, representavam uma parcela maior que não utilizava método algum no momento da investigação e pela pouca opção em relação a tais métodos, visto que "a pílula e a esterilização respondem por $83 \%$ da regulação da fecundidade, em contraposição com os $76 \%$ verificados no grupo das mulheres brancas" (Perpétuo, 2000).

A infertilidade resultante da esterilização precoce torna-se um verdadeiro drama na vida das mulheres que se submeteram à laqueadura e se arrependeram.

Consolidou-se de forma perversa uma cultura reprodutiva onde, ainda muito jovens, as mulheres, por desinformação e ausência de outras alternativas, incluem em seu projeto de vida a cesariana e a esterilização. Por esta opção pagam caro, pois além da mortalidade referida herdam seqüelas quase sempre definitivas, aumento da mortalidade perinatal e altas e inconcebíveis taxas de arrependimento pós-laqueadura. Os estudos dedicados ao arrependimento pós-laqueadura estabelecem uma relação direta entre esta situação e a desinformação sobre a existência e disponibilidade de outras alternativas contraceptivas, bem como a reversibilidade do procedimento cirúrgico. Em significativo percentual, as esterilizações são realizadas no curso das cesarianas, 
freqüentemente indicadas com o objetivo da realização simultânea da laqueadura. As altas taxas de cesariana que o Brasil exibe estão entre as mais elevadas do mundo. (Costa, 1996)

Observando-se a Tabela 1, a seguir, vê-se que até 39 anos já existem $50 \%$ de mulheres esterilizadas, encontrando-se 30\% de mulheres laqueadas antes dos 30 anos.

Tabela 1 - Percentual de mulheres esterilizadas, segundo idade. Brasil, 1996

\begin{tabular}{cc}
\hline Idade (anos) & $\%$ \\
\hline $15-19$ & 0,1 \\
\hline $20-24$ & 5,9 \\
\hline $25-29$ & 21,1 \\
\hline $30-34$ & 37,6 \\
\hline $35-39$ & 49,0 \\
\hline $40-44$ & 53,4 \\
\hline $45-49$ & 47,6 \\
\hline Total & 27,3 \\
\hline & \\
\hline
\end{tabular}

Fonte: Bemfam (1997).

De acordo com o Boletim Eletrônico Saúde Reprodutiva na Imprensa (2003), comprovou-se que em torno de 59\% das mulheres que foram esterilizadas optaram pela cirurgia por desconhecimento de outros métodos contraceptivos e, segundo este Boletim, "é justamente essa falta de informação sobre métodos contraceptivos que leva as mulheres a fazerem 
a esterilização". O procedimento de reversão da laqueadura, além de ser possível só em alguns casos sem garantias de que ocorra uma gravidez, tem o problema sério que é a inexistência de serviços de tratamento de infertilidade ou de reprodução em várias regiões do país. Nos locais onde existem tais serviços, a fila de espera é longa. As chances de recuperar a fertilidade são de apenas $60 \%$, porque o funcionamento das trompas fica prejudicado (Boletim Eletrônico Saúde Reprodutiva na Imprensa, 2003).

Também chamam a atenção outros dados divulgados pelo Departamento de Informática do Sistema Único de Saúde (Datasus):

51 mil crianças e adolescentes foram atendidas em hospitais, em 2000, por complicações do aborto. Três mil tinham entre 10 e 14 anos. Dados do Sistema Único de Saúde (SUS) mostrados no Mapa da Criança e do Adolescente, em matéria que afirma que os abortos estão ligados à alta incidência de gravidez precoce. (Boletim Eletrônico Saúde Reprodutiva na Imprensa, 2003)

Tudo isto comprova a pouca atenção que o Sistema de Saúde oferece à população pobre do nosso país em relação à saúde reprodutiva. Além disso, muitas crianças e adolescentes apresentarão seqüelas de aborto que redundarão em esterilidade que poderia ser evitada se a lei descriminalizasse o aborto. A discussão sobre o aborto não será aqui discutida, pois já foi abordada por outros autores neste livro.

Outro fator que merece ser considerado é a pressão social, ainda existente, pró-natalista sobre a mulher, na qual se valoriza a maternidade e se mistura o papel de mãe com o da mulher:

Ser mulher ainda seria sinônimo de ser mãe. Tal concepção deveria ser totalmente modificada, no sentido de reforçar que a maternidade não seria seu principal papel, encorajando a compreensão da maternidade como possibilidade, e não como uma escolha necessária, com facilitação da adoção ou da promoção de diferentes formas de afeição materna. (Braz \& Castro, 2003) 
Isto quer dizer que se o papel de mãe ainda é fortemente cobrado e mitificado pela sociedade, uma mulher infértil se sentirá obrigada a ter filhos, a qualquer custo, de qualquer modo. E o homem, que ainda tem sua imagem de virilidade ligada à possibilidade de gerar filhos, da mesma maneira se sentirá compelido a tê-los. Este, de modo geral, é o quadro do problema de infertilidade e da anticoncepção no Brasil, onde, apesar do Programa de Atenção Integral à Saúde da Mulher (PAISM), pouco se tem avançado no sentido de corrigir tais distorções.

As questões bioéticas que se apresentam podem ser expressas pela falta de autonomia das pessoas em decidir sobre o melhor método, já que a eles não têm acesso, seja por desinformação, seja pela ausência de serviços de saúde. Do mesmo modo, ocorre uma injustiça em relação à prevenção dos problemas e ao seu tratamento quando eles se configuram. Parece haver uma política velada de não investir nas causas de infertilidade e no seu tratamento, já que muito claramente a política, nos países em desenvolvimento, é diminuir a prole para combater a miséria. Quanto mais filhos as pessoas pobres tenham (que fique claro que toda a preocupação com a prole se refere aos pobres) menos chances estas crianças teriam de se tornar cidadãos livres e responsáveis. Tudo isto é inferido pelos números que apontam que, quanto mais pobre, mais filhos, como se uma coisa causasse a outra, quando o que ocorre é justamente o contrário, como também postulado por Moser (1996):

Particularmente no que se refere à reprodução das populações pobres, é necessário tomar como ponto de partida outro postulado: os pobres não são pobres porque se multiplicam tanto e tão rapidamente, mas se multiplicam tanto e tão rapidamente porque são pobres.

Esquece-se de que se a miséria for combatida, se melhorar o acesso à informação e aos serviços de saúde com qualidade, tal questão não demandará discussão. Há uma crença de que a miséria acabará se os pobres pararem de procriar. Este é um fato que não se pode deixar de apontar. Realmente, seria necessário atacar a pobreza, diminuir as desigualdades existentes, incluir as pessoas de tal modo que todas pudessem se sentir 
cidadãs. Este é o caminho que a Bioética propõe porque é o moralmente correto e necessário para proteger a população excluída que ainda compõe, infelizmente, a maioria no Brasil.

\section{Reproduç̃o Humana e a Liberdade de Procriaç̃o}

O movimento feminista, o avanço das técnicas e a produção de novos medicamentos mudaram de forma importante a relação da mulher com o seu corpo. O corpo passa a ser domínio de cada mulher em particular e, daí por diante, ela pode decidir se e quando terá filhos, graças aos métodos contraceptivos, principalmente à pílula. Paralelamente a isto, o aborto tornase realidade em muitos países. Isto é entendido como liberdade de procriação. Pode-se dizer que, apesar de essa afirmação ser verdadeira, no caso brasileiro, ainda não se coloca esta questão para a maior parte da população.

Vários direitos como estudar e trabalhar, alcançados pelas mulheres em sua busca pela igualdade com os homens, vêm trazendo à tona uma outra questão que surte impacto sobre elas, que é a postergação da maternidade e, com ela, uma dificuldade maior de engravidar que tem sido tratada através das Novas Tecnologias de Reprodução (NTRs).

Quando se fala em liberdade de procriação, parte-se do princípio de que a política não deve se intrometer na vida das pessoas regulando quando e quantos filhos devem ter. De fato, isto ocorre na procriação dita 'natural' - por meio de uma relação sexual. Já a reprodução dita medicalizada, assexuada ou artificial é regulada por normas e leis, existindo um controle social sobre a mesma que pode ser questionado (Mori, 2001). As NTRs são controladas porque há vários níveis de preocupação em relação, principalmente, ao desejo de ter filhos de qualquer maneira, mesmo contra a 'natureza'. Muitos autores que se colocam contra estas tecnologias o fazem imbuídos de uma ética naturalista, aquela que considera que é bom o que é natural e mau o antinatural, e por uma razão supostamente essencial, visto que a natureza possuiria um finalismo intrínseco ou telos. 
Para justificar isso, recorre-se, muitas vezes, a Aristóteles, para quem, conhecer os fins humanos significa observar suas práticas efetivas, as quais seriam orientadas pelos fins, que atuariam por atração e apontariam, em última instância, o caminho da prudência, situado entre os excessos e os defeitos, isto é, 'o meio justo'. Nesse sentido, as decisões e as normas têm de fornecer respostas à 'natureza humana', o que permite aos humanos se relacionarem entre si e com a natureza naquilo que se denomina harmonia antropocósmica, ordenando, assim, sua vida interior, que é a harmonia espiritual (Schramm, 2004). Tudo o que contrarie este princípio prudencial é visto como errado e, se não houver outro modo, o procedimento deverá ser fonte de vigilância, normas e leis, de modo a tentar normalizálo. Os atos possuem, dentro desta visão, algo intrinsecamente bom ou intrinsecamente mau, sendo que os primeiros respeitariam a ordem interna da natureza e os maus a contrariariam (Gracia, 1998). Nesse sentido, nada mais há de antinatural do que a procriação artificial e - ainda mais estranho e que foge da finalidade da natureza - a clonagem reprodutiva.

O direito à liberdade procriativa refere-se à liberdade de uma pessoa determinar se terá ou não filhos e como evitá-los. Segundo Mori (2001), o direito à liberdade procriativa pode ser subdividido em dois: 1) liberdade de procriar sem interferência de outros, tanto fazendo um ser 'naturalmente' (através de relações sexuais) ou por técnicas de reprodução, no seio de uma família tradicional ou não, como até o tipo de crianças que nascerão; 2) liberdade de evitar a procriação, dependente do método que pode ser por abstinência, uso de contraceptivos, pela esterilização ou aborto.

Alguns argumentos são utilizados para fundamentar o direito moral à liberdade reprodutiva, quais sejam: 1) o princípio da autonomia, já que esta é uma decisão bastante pessoal, porque a concepção muda a vida das pessoas, o sentido que se atribui à vida e a identidade de cada um; 2) o argumento utilitarista, que postula que este direito contribui para o bem-estar geral, mas que, entretanto, sofre seu contraponto que é a superpopulação, o abandono de crianças com o conseqüente aumento da miséria, oferecendo, desta forma, argumentos a favor do direito de não procriar; 3) o princípio da igualdade, defendido pelas feministas, que aponta 
para o lugar da mulher na sociedade, identificado com a função materna e, portanto, com as decisões pesando mais sobre ela. $\mathrm{O}$ direito à liberdade facilitaria a eliminação de uma forma de desigualdade (Mori, 2001).

Em relação aos direitos de reproduzir, existem dois tipos: 1) negativos, que se referem à não-interferência dos outros na decisão, isto é, nada deve interferir nas decisões reprodutivas de uma pessoa; no entanto, pode-se considerar como havendo direito positivo quando se impõe ao Estado a previsão de alguns cuidados em saúde, como contraconceptivos e aborto (Salles, 1998); 2) positivos, que requerem outras pessoas (Salles, 1998) e, neste caso, além do citado, temos o caso da reprodução medicamente assistida.

Cabe ressalvar que a evidência da existência de limites morais não respalda a afirmação de que, em certos casos, devem existir obrigações legais de não procriar. A liberdade de não procriar implica que uma pessoa tem o direito de não ter filhos se isto for fruto de uma decisão autônoma e voluntária por duas razões: 1) respeito à autonomia, significando que não procriar é um direito à liberdade de gerir a própria vida; 2) autodeterminação em relação ao próprio corpo.

Este direito de não procriar, infelizmente, ainda não deu origem a um princípio correspondente à liberdade de procriar (Mori, 2001) - aqui se fala da procriação natural -, já que a decisão de não ter filhos implica muitas vezes em esterilização, sujeita ao controle social e ao aborto proibido na maioria dos casos.

Surge, então, a questão do direito à procriação e a doutrina da tutela do 'interesse do nascituro'. Não procriar, para Mori (2001), seria uma liberdade absoluta porque sua prática não causaria dano a ninguém, considerando-se o argumento de que não se pode lesar a quem não existe ou não o fazendo existir. Por outro lado, para este autor, a liberdade positiva (procriar) deveria ser controlada e limitada, porque seu exercício pode causar danos àquele que nasce. Nesse sentido, o critério inspirador que deve servir de guia é a 'tutela do bem-estar do nascituro'. 
Não é lícito querer ter um filho

a todo custo, forçando até mesmo os limites naturais. O desejo de ter um filho é 'apreciável', mas não indispensável nem fundamental (...) Em muitos casos, o desejo de ter um filho não é em nada algo supérfluo e frívolo; pelo contrário, a decisão de fazer nascer um filho é um aspecto importante e crucial para o próprio projeto de vida, pois constitui um compromisso para com a existência. (Mori, 2001: 67)

Preocupações em relação às crianças geradas de forma nãoresponsável, isto é, sem preocupação com seu destino, com os cuidados que se deve ter em relação a esta parcela desamparada e mais vulnerável da humanidade, são fonte de discussões morais. Um dos argumentos mais usados é que, em relação à reprodução 'natural', nenhum tipo de coerção deve existir porque seria um desrespeito à autonomia das pessoas, podendo ser usado de forma discriminatória visando à seleção de pessoas consideradas aptas a procriarem. No entanto, a reprodução assistida é regulada, e vários tipos de interdição são colocados e, neste caso, tal direito seria desrespeitado. Isto porque existem critérios de seleção de quem pode ser o beneficiário da técnica

Muito embora, constitucionalmente, seja assegurado o direito a qualquer tipo de procriação, seja natural ou assistida, na prática a parcela pobre da população não tem acesso à reprodução medicamente assistida ou, quando tem, isto se faz, com exceções, de forma moralmente inaceitável. Certos serviços públicos que oferecem tal procedimento fazem-no trocando os óvulos da mulher pobre pelos medicamentos pagos pelas ricas que deles necessitam, usando-se o eufemismo de doação de óvulos (Braz \& Schramm, 2003). Além desta questão, há várias outras, motivo de polêmica no campo da reprodução medicamente assistida, que serão vistas em seguida.

\section{Reproducão Humana Assistida (RHA)}

Sabe-se que a queda da taxa de nascimentos é um problema sério em vários países desenvolvidos, onde, pelas mudanças sociais e científicas, 
a gravidez deixou de ser o objetivo principal do matrimônio (Greer, 1987). Acresce-se a isto o adiamento da gravidez para idades mais avançadas, de modo que a fertilidade da mulher sofre um sério declínio, assim como aumenta a chance de gerar crianças com anomalias. Junte-se a isto as questões abordadas sobre a infertilidade e teremos, então, um quadro mais amplo das pessoas que querem recorrer às NTRs.

A possibilidade de utilizar o recurso das NTRs e a sua aceitação crescente trouxeram novas questões e conflitos tanto para a sociedade como para os legisladores e os bioeticistas. Em quase todos os países, foram formuladas normas e leis - em alguns casos, mais liberais e, em outros, mais rígidas. A questão que mobiliza os bioeticistas está não tanto na tecnologia em si, mas na aplicação dela que suscita problemas que podem também demandar ordenamento jurídico, no sentido de traçar limites e direitos para a liberdade de procriar. Por outro lado, há um alerta para esta questão que passa pela intromissão do público no privado, porque existe um aumento crescente da intervenção dos governos nacionais no interior das instituições de saúde que se estendem no sentido de controlar a doação e a disposição de gametas e embriões humanos. Segundo Diaz et al. (2002: 1), "desta forma a tecnologia reprodutiva se converte numa desculpa para fomentar duas tendências: a já presente 'medicalização' da reprodução e a 'judicialização' da gravidez".

Outras questões, de fato, implicam a necessidade imperiosa da criação de novas leis, ou modificação das já existentes, tais como: os aspectos relacionados à filiação, herança, paternidade, maternidade, como também aos direitos de família e os direitos à vida (Diaz et al., 2002). Para além da regulamentação, a reprodução assistida vem sendo motivo de debates e se constitui, de acordo com Corrêa (2001), em um dos principais problemas vivenciados pela Bioética e que cresce em função da cobertura ostensiva realizada pelos meios eletrônicos.

Levando-se em conta os problemas vivenciados pelas pessoas inférteis, como já visto anteriormente, pode-se considerar a infertilidade como um problema de saúde que pode ser solucionado de acordo com as técnicas reprodutivas existentes e, naturalmente, as NTRs estão aí incluídas. 
Tal postura pode ser contestada por outra, que implica, de um ponto de vista utilitarista, argumentar que, em países em desenvolvimento (como é o caso do Brasil), com escassos recursos e vários outros problemas graves que atingem o bem-estar e a saúde da população, seria fundamental dar prioridade às políticas de saúde que enfrentem e solucionem patologias mais prevalentes e preveníveis, consideradas mais importantes do ponto de vista de controle social, pelo fato de afetarem um grande número de pessoas. No entanto, cabe lembrar, novamente, que o percentual de pessoas que sofrem de infertilidade é bastante considerável, assim como não se pode ignorar o sofrimento que acarreta e, nesse sentido, é uma questão para a saúde pública, visto que:

8 milhões de casais brasileiros são inférteis. 10 mil implantações de bebês são feitas por ano, no Brasil, três vezes menos do que na Espanha. Apenas 0,8\% das mulheres que precisam ser submetidas à reprodução assistida conseguem atendimento nos hospitais, nas clínicas e nos consultórios. (Boletim Eletrônico Saúde Reprodutiva na Imprensa, 2003)

Nesse sentido, a história de Suzana de Oliveira Miossi, 30 anos, é comovente:

Aos 24 anos, ela resolveu ligar as trompas no momento em que deu à luz sua filha, Eloisa Carolina. O parto foi uma cesariana, o que facilitou o processo. Suzana e o marido, o comerciante Antonio Carlos, já tinham um filho, e achavam que duas crianças era o número ideal. Mas aconteceu o imprevisto. Eloisa nasceu com os pulmões prematuros e ela morreu alguns dias depois, ainda no berçário. Era o início de um calvário pelo qual Suzana jamais imaginou passar. Ela foi desencorajada por diversos especialistas a reverter a laqueadura. Sem recursos para pagar uma proveta, percorreu várias clínicas na esperança de encontrar um orçamento que coubesse em seu bolso. Em vão. (Gullo \& Vitória, 1996)

Estas duas citações mostram o drama das pessoas que desejam ter um filho pelas NTRs e não conseguem. Além desta questão da eqüidade do acesso aos tratamentos existentes, outros pontos são levantados quando 
se debate a RHA, quais sejam: 1) em quais circunstâncias se deve utilizar o recurso; 2) quem pode se beneficiar da técnica; 3) a gravidez de substituição; 4) quantos embriões podem ser transferidos; 5) o congelamento de embriões, o tempo de congelamento; 6) o destino dos embriões congelados; 7) diagnóstico pré-implantatório; 8) a questão do sigilo dos doadores de gametas.

Atualmente, tramitam no Congresso Nacional alguns projetos que visam a legislar sobre este tema. Até hoje, os médicos seguem a Resolução 1.358, de 11/11/1992, do Conselho Federal de Medicina (CFM), que em relação a estes tópicos tem as seguintes deliberações:

Toda pessoa maior e capaz tem direito ao planejamento familiar na forma da lei, no entanto, em relação ao item 1 e 2, esta Resolução e as leis que tramitam no congresso limitam esta prática. Isto porque o recurso só deve ser utilizado em casais que sofram de infertilidade, o que exclui, por exemplo, mulheres solteiras ou casais homossexuais.

As pessoas excluídas, seja pela opção de manterem-se sozinhas, seja pela orientação sexual, não podem recorrer ao método. Os que defendem a posição de estender o direito nestas situações baseiam-se no fato de que a adoção de crianças já é permitida nestes casos e, assim sendo, não há por que não garantir o direito à reprodução assistida também. Do mesmo modo, argumenta-se que existem várias mudanças ocorridas no seio das famílias, Aquelas ditas 'normais', com pai, mãe e filhos, cada vez mais estão desaparecendo e, em seu lugar, novos modos de organização familiar estão surgindo (Roudinesco, 2003). Evidentemente, não há uma proibição explícita no texto do CFM quanto à questão da orientação sexual dos beneficiários da técnica, mas ela está implícita ao só permitir a reprodução assistida aos casados ou em união estável. Tal fato se configura como discriminação e sob o ponto de vista da Constituição não se pode discriminar pessoas em função disto. Como aponta Rios (2002: 66):

Seja como for, a mera possibilidade da utilização da tecnologia reprodutiva com propósitos discriminatórios acarreta, para 
homens e mulheres homossexuais, inúmeros prejuízos, principalmente em virtude do cultivo de atitudes e percepções negativas diante da homossexualidade, do reforço da preferência pela heterossexualidade, da fragilização das posições políticas e sociais dos grupos homossexuais e do conseqüente incentivo da ocultação da orientação sexual, mesmo daqueles que optam por fazê-la ultrapassar o foro privado e atingir a esfera pública.

Este autor enfatiza que a desigualdade neste aspecto se reveste "de um risco de 'genocídio homossexual' e de 'eugenia heterossexual'" (Rios, 2002: 66).

O projeto de lei do senador Lúcio Alcântara (Projeto Ghente, 2003) acompanha esta tendência de só permitir o recurso à técnica em casos de infertilidade, o que será uma perda da possibilidade de avançar em relação aos direitos dos homossexuais e das pessoas solteiras. De qualquer modo, recomenda-se que a utilização das NTRs se justifique apenas como procedimento que auxilie na resolução de problemas relativos à procriação. Desta forma, o recurso às técnicas deve se dar quando houver limitação à reprodução natural e nos casos em que possa ocorrer um risco da geração de filhos com patologias genéticas graves, hereditárias ou não. A prática deve continuar a ser vista como excepcional, gerando sempre mais benefícios do que riscos, principalmente para os filhos. Esta posição, entretanto, não exclui as pessoas solteiras ou os casais homossexuais se houver aceitação da expressão 'limitação da procriação', sem especificar a infertilidade como único motivo para usar o recurso.

A Resolução do CFM permite a gestação de substituição apenas nos casos da existência de um problema médico impeditivo ou contra-indicado pela mulher que necessita da técnica. Em condições excepcionais, será autorizada a gestação de substituição desde que exista parentesco em linha reta ou colateral até o segundo grau, o que é bastante limitante, entre a(o) beneficiária(o) da técnica e aquela que consente em gestar o filho. Há uma tendência a ampliar o parentesco para o terceiro grau, pois até o segundo implica que somente a mãe da beneficiária ou sua irmã ou filha poderiam 
ser gestantes substitutas. Neste aspecto, o texto também preconiza que a gestação de substituição não deve ter caráter remuneratório e a definição da filiação materna é conferida à beneficiária da técnica.

Existem pressões de determinados grupos que visam a excluir a possibilidade da gravidez de substituição, o que não parece razoável se alguma outra mulher estiver disposta a gestar por outra. A proibição, se for levada em consideração no Congresso Nacional, é um retrocesso importante em relação à Resolução do CFM. Isso porque, nos casos em que exista uma impossibilidade de a beneficiária da técnica poder gestar, por problemas uterinos ou pela ausência do mesmo, a única saída é a gestação de substituição. Proibir a gestação de substituição impede o acesso das portadoras desse problema a uma das ações que fazem parte do atendimento integral à saúde da mulher. A proibição, que não está amparada por qualquer justificativa sob o ponto de vista moral ou legal, afronta, inclusive, um direito garantido pela Constituição Federal Brasileira, que, em seu art. 226, parágrafo $7^{\circ}$, preconiza:

Fundado nos princípios da dignidade da pessoa humana e da paternidade responsável, o planejamento familiar é livre decisão do casal, competindo ao Estado propiciar recursos educacionais e científicos para o exercício desse direito, vedada qualquer forma coercitiva por parte de instituições públicas e privadas.

Este parágrafo foi regulamentado pela Lei n. 9.263, de 12 de janeiro de 1996, em seu artigo 90, onde fica estabelecido:

Para o exercício do direito ao planejamento familiar, serão oferecidos todos os métodos e técnicas de concepção e contracepção, cientificamente aceitos e que não coloquem em risco a vida das pessoas, garantida a liberdade de opção.

Parágrafo Único: A prescrição a que se refere o caput só poderá ocorrer mediante avaliação e acompanhamento clínico e com informação sobre seus riscos, vantagens, desvantagens e eficácia. (grifo meu) 
Obviamente, há que se concordar que a gestação de substituição não seja remunerada, pois, além de ferir o disposto no artigo 199, parágrafo $4^{\circ}$, da Constituição Federal, que veda todo tipo de comercialização de órgãos, tecidos e substâncias humanas para fins de transplante, pesquisa e tratamento, afronta a dignidade da pessoa porque se sabe que as mais vulneráveis e menos favorecidas socialmente poderão ser usadas pelas mais afortunadas para engravidar por elas.

Uma questão importante que se coloca refere-se ao consentimento livre e esclarecido. Na Resolução do CFM, consta o termo consentimento informado, que seria um documento em formulário especial completado com a concordância, por escrito, da paciente ou do casal infértil. Deve-se enfatizar que o termo precisa ser nomeado e incorporado à prática médica no sentido de ser uma decisão livre e, portanto, autônoma e esclarecida, ou seja, os beneficiários da técnica devem ser completamente esclarecidos sobre os riscos, as conseqüências e as taxas de sucesso referentes ao que se denomina 'bebê em casa'. Também os doadores de gametas deveriam assinar o termo e não apenas os beneficiários. Importante apontar que o consentimento deve e pode ser revogado por qualquer parte a qualquer momento, por arrependimento, divórcio ou morte.

No caso do número de embriões a serem transferidos, a Resolução prevê um número máximo de quatro no intuito de evitar gravidezes múltiplas. Os projetos em tramitação preconizam dois ou no máximo três embriões a serem transferidos em função do aumento de multiparidade que vem ocorrendo, já que não pode haver redução embrionária. Também há projetos que querem impedir o congelamento de embriões em função do destino que se deve dar aos excedentes, isto é, não transferidos.

Logicamente deve haver a preocupação de transferir o mínimo possível, sendo que hoje se preconiza a transferência de até três embriões em função da faixa etária. Mulheres acima de 35 anos têm mais dificuldade em engravidar e este número aumenta as chances.

Neste ponto não se pode ignorar que a redução embrionária, proibida no Brasil, tem a mesma ideologia contida quando se fala em descarte de embriões ou sua destruição, como questiona Queiroz (2002: 28): 
Juridicamente, o ponto relevante da utilização da redução seletiva está na semelhança que esta apresenta em relação ao aborto, seu correlato clínico. Como tratar, então, o aborto e a redução embrionária de formas distintas no âmbito legal? Como, por sua vez, discutir o descarte embrionário numa perspectiva jurídica tendo em vista que o embrião fecundado laboratorialmente contém material genético de duas pessoas?

Este é o ponto relevante na discussão e por trás do aborto se coloca o problema do estatuto do embrião, isto é, se e quando se pode considerar um embrião como uma pessoa. Esta discussão está contida neste livro em artigo próprio.

Em relação ao destino dos embriões, a questão ética passa pelo que fazer com os excedentes ou também pela desistência de implantar. A atual Resolução prevê o congelamento em seu artigo V, transcrito a seguir:

V - CRIOPRESERVAÇÃO DE GAMETAS OU PRÉ-EMBRIÕES

1 - As clínicas, centros ou serviços podem criopreservar espermatozóides, óvulos e pré-embriões.

2 - O número total de pré-embriões produzidos em laboratório será comunicado aos pacientes, para que se decida quantos pré-embriões serão transferidos a fresco, devendo o excedente ser criopreservado, não podendo ser descartado ou destruído.

3 - No momento da criopreservação, os cônjuges ou companheiros devem expressar sua vontade, por escrito, quanto ao destino que será dado aos pré-embriões criopreservados, em caso de divórcio, doenças graves ou de falecimento de um deles ou de ambos, e quando desejam doá-los.

O que fazer com os embriões atualmente congelados nas clínicas? De acordo com os dados divulgados por uma revista de circulação nacional, já existiriam 20 mil embriões congelados no Brasil (Oliveira, 2002). Quando da aprovação da nova Lei de Biossegurança, em 2005, descobriu-se que existem apenas 3 mil embriões congelados nas clínicas. Com esta lei, fica 
autorizada a utilização de embriões criopreservados com vistas à pesquisa de células-tronco (Lei n. 11.105, de 24/03/2005).

Tenta-se evitar esta questão proibindo-se o congelamento, o que não parece ser a melhor solução, tendo em vista que o procedimento para fertilização in vitro, além de oneroso, oferece riscos pela quantidade de hormônios que a mulher deve tomar para aumentar a produção de óvulos maduros. Ela pode desejar guardar seus embriões para outras gravidezes e, deste modo, terá de se submeter a um novo tratamento.

Quanto tempo os embriões devem ser congelados? Preconizava-se cinco anos, só que experiências atuais mostram a viabilidade de embriões que foram implantados depois de uma década (Oliveira, 2002). Deixar por tempo indefinido, no entanto, coloca em evidência outro problema de difícil equacionamento: a angústia das pessoas que deixam nas clínicas os embriões. Numa reportagem do jornal O Globo (2003), um médico, que trabalha em fertilização disse que há casais que 'esquecem' os embriões e outros que ligam sempre para saber como estão (os filhinhos?). Não se sabe se aqueles que 'esquecem' de fato olvidam ou se por algum mecanismo de defesa, por não saber o que fazer, tentam se desligar do problema, restando, contudo, sempre um mínimo de desconforto. Pela nova Lei de Biossegurança, os embriões congelados há três anos ou mais podem ser utilizados para pesquisa com células-tronco.

Desse modo, seria importante estabelecer um prazo máximo findo o qual os embriões deveriam ser descartados, doados ou liberados para a pesquisa, desde que as pessoas beneficiárias concordem com o destino. Não parece correto, sob o ponto de vista moral, deixar as pessoas ligadas, para sempre, a um material biológico, material reprodutivo, feto, préembrião, concepto, criatura concebida (Puerto, 2000), denominações diversas que tentam substituir a palavra embrião, no intuito de desviar a atenção da questão que se coloca em relação ao estatuto do mesmo, isto é, se ele é ou não uma pessoa. Em muitos casos, deixar o embrião congelado nas clínicas pode implicar um grau de sofrimento e até, de maneira velada, ser uma forma de punição por atentar contra a natureza: “Jamais esquecerás o que fizestes". 
Outra questão emergente é a do diagnóstico pré-implantatório, hoje prática comum nos consultórios. As posições são divergentes. Alguns argumentam que estes testes visam, no fundo, à eugenia, à escolha de sexo e, futuramente, à cor dos olhos e cabelos, à estatura, à inteligência. A escolha do sexo já é realizada em clínicas, apesar da proibição. Se a reflexão for em direção da liberdade de procriação, não há como negar o direito de uma pessoa ter um bebê como sonhado em sua fantasia. Entretanto, muitos bioeticistas condenam aquilo que denominam de bebê de encomenda (Thévenon, 2003; Testart \& Godin, 2001). A proibição parece ser consensual, admitindo-se o diagnóstico genético pré-implantatório nos casos que visem à prevenção da transmissão de doenças genéticas em famílias de risco.

A questão do sigilo sobre a identidade dos doadores também é polêmica. Países como a Suécia e alguns estados americanos vêm abrindo o sigilo dos doadores após a criança concebida completar 18 anos. Na Resolução atual e nas leis em tramitação, permanece o sigilo da identidade dos doadores.

O argumento mais utilizado se dá em função da possibilidade de a criança ou a mãe vir a requerer, na Justiça, pensão alimentícia ou mesmo parte da herança e, por isso, haveria uma recusa das pessoas em quererem ser doadoras caso o sigilo fosse quebrado. No entanto, algumas questões necessitam ser debatidas além dos interesses das pessoas envolvidas neste processo e que excluem a criança. Refletindo-se analogamente com o caso das crianças adotadas, já se assistiu a muitos problemas, principalmente de cunho emocional, até que as pessoas compreendessem que deveriam falar a verdade para as crianças. As leis em vários países já deixam à disposição os dados necessários para a busca dos pais genéticos se o adolescente assim o desejar. Foi necessário muito sofrimento por parte destas crianças e destes adolescentes para a quebra do sigilo que envolvia a adoção. O mesmo ocorrerá com a reprodução assistida. Lachowicz (1996: 138) diz que, no "caso dos filhos nascidos com gametas de terceiro, não está alheia a aplicação dos mais atuais princípios acerca do respeito a seu direito a conhecer sua verdadeira identidade biológica". Mais adiante, completa: 
não se pode deixar de ressaltar que se está dispondo do estado civil de uma criança que está por nascer, que será desde sua concepção e de forma deliberada 'filho' de seus pais jurídicos que não coincidem com seus pais biológicos: afeta-se a identidade do filho. (Lachowicz, 1996: 141)

A verdade é sempre melhor, nestes casos, do que os argumentos frágeis utilizados para manter o anonimato, que é o da possibilidade de diminuição dos doadores. Se uma pessoa se dispuser a ser doador sabendo que no futuro poderá vir a conhecer o filho gerado, implica, evidentemente, numa maior responsabilidade e, neste sentido, uma maior motivação altruísta. Por outro lado, não podemos esquecer de que os avanços científicos descortinam mais e mais possibilidades de curar doenças até agora incuráveis, nas quais a linhagem genética se faz importante para a elucidação, como, por exemplo, as doenças hereditárias de expressão tardia. Até o momento, há preocupação em relação ao transplante de órgãos ou tecidos do corpo. Se há desconhecimento dos doadores, diminui a chance de uma pessoa se beneficiar do único tratamento que pode restar - o transplante.

A tendência internacional é assegurar o direito à identidade genética da criança, o que não deve acarretar parentesco ou mesmo qualquer outro efeito jurídico em relação aos doadores. Deve ser assegurado ao filho a parentalidade afetiva daqueles que recorreram à técnica para alcançar seu projeto parental, que só por isso constitui a filiação jurídica reconhecida através da certidão de nascimento.

Finalizando, não se pode deixar de sugerir que deva haver uma instância de controle social responsável pela concessão de licença de funcionamento, fiscalização e atuação de clínicas e serviços de saúde que realizam as NTRs no Brasil, assim como um banco de dados que organize e elabore estatísticas, tornando disponíveis os dados sobre o número de embriões congelados, de bebês em casa, taxas de insucesso (abortos, não-fecundação etc), incidência e prevalência dos efeitos colaterais, nascimento de crianças com malformações e demais complicações. Também devem estar disponíveis as clínicas e os serviços 
de saúde públicos que fazem o procedimento, assim como os profissionais habilitados para executá-lo.

No Brasil, houve um elevado crescimento de clínicas de fertilização que necessitam de regulamentação para assegurar os direitos e deveres de cada parte envolvida no processo, assim como a saúde dos que demandam a técnica. Além da importância de que o recurso à fertilização ocorra em condições de segurança, deve-se estar atento para debater as questões éticas que mais e mais vão se colocando com a manipulação genética. É preciso ter cuidado ao legislar, porque a mudança de lei é um processo demorado e a Ciência avança em largos passos. É melhor traçar princípios e normas éticas do que fazer leis que podem dificultar a vida das pessoas ou impedir o progresso científico.

Por fim, entre as diversas posições a favor ou contra a utilização, a posição Bioética laica que parece a mais adequada é expressa por Segre e Schramm (2001: 43-44), quando escrevem:

Distinguindo-nos das posições moralistas (...) essencialmente preocupadas com os argumentos que visam a proibição, (...) defendemos o ponto de vista ético da aceitabilidade prima facie das técnicas e biotécnicas de reprodução assistida - ou NTRs - que consideramos necessárias para enfrentar problemas ligados à reprodução humana, desde que tal aceitação seja fruto do exercício da autonomia responsável em termos de reprodução, esteja acompanhada pela indispensável vigilância em termos de biossegurança e uma razoável garantia de respeitar e/ou ponderar os direitos fundamentais dos sujeitos morais envolvidos.

Esta parece ser a posição mais sensata, pois, ao mesmo tempo, assegura o pleno exercício da autonomia enfatizando o lado responsável que deve acompanhar não só esta tomada de decisão, mas todas as outras que implicam em riscos. Fazer fertilização in vitro tem risco não-desprezível devido à possibilidade de aumentar as chances de desenvolvimento de neoplasia endometrial e devido aos sofrimentos oriundos de fracassos sucessivos que podem ocorrer - e ocorrem. Estes pontos têm de ser enfatizados pelos profissionais que dominam a técnica para que o 
consentimento se dê de forma absolutamente autônoma e só depois de esgotados todos os outros meios, inclusive os de ordem emocional que possam ser utilizados para reversão da infertilidade ou mesmo a possibilidade de abertura para novas formas de parentalidade que não seja pela gestação obrigatória. Muitos querem passar seu patrimônio genético e não aceitam outra forma de ter um filho. Entretanto, outros não têm como transmiti-lo, por serem inférteis, e lançam mão da gestação de substituição com embriões doados. Não cabe aqui a discussão sobre a motivação ou o desejo destas pessoas, porque cada uma traz um sentido diferente. De qualquer modo, uma pesquisa feita pela City University de Londres comprova que as mães que utilizam outras mulheres para gestar são "mães mais carinhosas e dedicadas" (Oliveira, 2002: 33).

Nota-se, dessa forma, de quanto preconceito e falta de informação podem se revestir tais discussões. Prós e contras devem ser pesados em cada caso, não se podendo generalizar em cima de apenas um caso e, por isso, condenar o procedimento ou parte dele.

\section{REFERÊNCIAS BiBLIOGRÁFICAS}

BEMFAM. Macro International Inc. Pesquisa Nacional de Demografia e Saúde, 1996. Rio de Janeiro: Bemfam, 1997.

BOLETIM ELETRÔNICO SAÚDE REPRODUTIVA NA IMPRENSA. 1: 30 set. 2003. Disponível em: http://www.redesaude.org.br/html/ body_boletim-01a30set-2003.html. Acesso em: 1 out. 2003.

BRASIL. Resolução n. 1358. Conselho Federal de Medicina. Brasília: CFM, 1992. http://www.portalmedico.org.br/resolucoes/cfm/1992/ 1358_1992.htm. Acesso em: 04 jan. 2004

BRAZ, M. \& CASTRO, L. Clonagem humana, reflexões bioéticas e psicanalíticas. Manufatura de humanos? Cyber Revue dos Estados Gerais da Psicanálise, 2003. Disponível em: http://www.estadosgerais.org/ mundial_rj/port/trabalhos/2e_Braz_72031003_port.htm. Acesso em: 25 out. 2003. 
BRAZ, M. \& SCHRAMM, F. R. O ninho vazio: a desigualdade no acesso à procriação no Brasil e a Bioética. Rio de Janeiro, 2003. (Mimeo).

COLLUCCI, C. Urologistas lançam livro sobre infertilidade masculina, 2002. Folha ONLINE, 20 jun. 2002. Disponível em: http:// ww 1 .folha.uol.com.br/folha/colunas/querosermae/ ult601u74.shtml. Acesso em: 5 jun. 2003.

COlluCCI, C. Por que a Gravidez não Vem? Rio de Janeiro: Atheneu, 2003. CORRÊA, M. V. Novas Tecnologias Reprodutivas: limites da biologia ou biologia dos limites? Rio de Janeiro: Eduerj, 2001.

COSTA, A. M. Planejamento familiar no Brasil. Revista Bioética, 4(2): 1996. Disponível em: http://www.portalmedico.org.br/revista/ind2v4.htm. Acesso em: 19 jan. 2004.

DIAZ, J. M. et al. Aspectos éticos y legales de la reproduccion asistida. Disponível em: http://wWw.cfm.org.br/bancotxt/des_etic/16.htm. Acesso em: 3 jun. 2002 .

GRACIA, D. Ética de los Confines de la Vida. Bogotá: El Búho, 1998.

GREER, G. Sexo e Destino: a política da fertilidade humana. Rio de Janeiro: Rocco, 1987.

GULlO, C. \& VITÓRIA G. Goooooooll! DE PROVETA. Isto É, 1996. http:// www.terra.com.br/istoe/capa/138503.htm. Acesso em: 15 dez. 2003.

HOJE ON LINE. Disponível em: http://www.jhoje.com.br/271203/ politica.asp. Acesso em: 4 jan. 2004.

JORNAL O GLOBO. Código civil muda a vida de casais inférteis. Jornal da Família, 29 set. 2003.

LACHOWICZ, M. Algunos aspectos de las legislaciones vigentes relacionadas con la aplicación de las nuevas tecnologias reproductivas. In: SOMMER, S. E. (Org.) Procreación: nuevas tecnologias: um enfoque interdisciplinario. Argentina: Atuel, 1996.

MACEDO, F. Reprodução humana (IV): o melhor tratamento. Disponível em: http://www.biosgenetica.com.br/artigos_iv.htm. Acesso em: 5 jan. 2004. 
MELO-MARTÍN, I. On cloning human beings. Bioethics, 16(3): 246-265, 2002.

MORI, M. Fecundação assistida e liberdade de procriação. Bioética, 9(2): 57-70, 2001.

MOSER, A. Política Demográfica: aspectos éticos. 4(2): 1996. Disponível em: http://www.portalmedico.org.br/revista/ind2v4.htm. Acesso em: 23 fev. 2004.

NETO, A. H. P. \& JÚNIOR, J. G. F. Reprodução assistida. In: COSTA S. I. F., GARRAFA, V. \& OSELKA, G. (Orgs.) Iniciação à Bioética. Brasília: CFM, 1998.

NEVES, P. A. \& NETTO JÚNIOR, N. R. Infertilidade Masculina. Rio de Janeiro: Atheneu, 2003.

OLIVEIRA, F. O "Estado da Arte" da Reprodução Humana Assistida em 2002. Brasília: Ministério da Justiça. Secretaria de Estado dos Direitos da Mulher, 2002.

PERPÉTUO, I. H. O. Raça e acesso às ações prioritárias na agenda da saúde reprodutiva. Jornal da Rede Feminista de Saúde, 22: nov. 2000. Disponível em: http://www.redesaude.org.br/jornal/html/body_jr22-encignez.html. Acesso em: $10 \mathrm{dez} .2003$.

PROJETO GHENTE. Reprodução assistida. Disponível em: http:// www.ghente.org/. Acesso em: 10 dez. 2003.

PUERTO, J. La consideración de los nuevos derechos humanos en la legislación sobre reproducción asistida. Acta Bioethica, VI(1): 128-140, 2000.

QUEIROZ, A. Tecnologias reprodutivas e direito: algumas conexões. In: DINIZ, D. \& BUGLIONE, S. (Orgs.) Quem Pode Ter Acesso às Tecnologias Reprodutivas? Diferentes Perspectivas do Direito Brasileiro. Brasília: Letras Livres, 2002.

RIOS, R. R. Acesso às tecnologias reprodutivas e princípios constitucionais: igualdade, pluralismo, direito constitucional da família e orientação sexual no debate bioético brasileiro. In: DINIZ, D. \& BUGLIONE, S. (Orgs.) Quem Pode Ter Acesso às Tecnologias Reprodutivas? Diferentes Perspectivas do Direito Brasileiro. Brasília: Letras Livres, 2002. 
ROUDINESCO, E. A Família em Desordem. Rio de Janeiro: Jorge Zahar, 2003. SALLES, A. Libertad reproductiva y sus límites. Conflictos materno-fetales. In: LUNA, F. \& SALLES, A. (Orgs.) Bioética: investigación, muerte, procreación y otros temas de ética aplicada. Buenos Aires: Sudamericana, 1998.

SCHRAMM, F. R. Abordagens formais da Ética Antiga (a) e da Ética Moderna (m). Aula no III Curso de Especialização em Ética aplicada e Bioética do Instituto Fernandes Figueira da Fundação Oswaldo Cruz. Rio de Janeiro, 2004 (Mimeo).

SEGRE, M. \& SCHRAMM, F. R. Quem tem medo das (bio)tecnologias de reprodução assistida? Bioética, 9(2): 43-56, 2001.

TESTART, J. \& GODIN, C. Au Bazar du Vivant. Paris: Seuil, 2001.

THÉVENON, E. Biotecnologias: o homem em perigo? A fabricação do ser humano. Label France, 49: jan. 2003. Disponível em: http:// www.france.org.br/abr/label/label49/dossier/02.html. Acesso em: 8 mar. 2003. 


\section{Bioética, Testes Genéticos e a Sociedade Pós-Genômica}

\section{9}

João Gonçalves Barbosa Neto

Marlene Braz

\section{INTRODUCC̃̃O}

No anúncio feito por Bill Clinton sobre o primeiro rascunho do genoma humano, o presidente norte-americano estava acompanhado de representantes da Celera Genomics - simbolizando, assim, o potencial do genoma humano como uma mina de ouro para a exploração biotecnológica - e dos cientistas representantes do consórcio, que tornaram pública nossa herança genética comum como espécie e fizeram uma descrição molecular do que é o ser humano e um registro molecular do nosso progresso evolucionário desde os primórdios. Foi um momento propício às palavras de esperança para os males físicos e mentais de que padecem os humanos. O presidente Bill Clinton (2000) disse:

Hoje, estamos aprendendo a linguagem na qual Deus criou a vida. Estamos tomando consciência da complexidade, da beleza, da maravilha do mais divino e sagrado presente de Deus. Com este profundo conhecimento novo, a humanidade está no limiar de ganhar um poder novo e imenso de curar. A ciência genômica terá um impacto real em todas as nossas vidas - e, mais ainda, nas vidas de nossas crianças. Revolucionará o diagnóstico, a prevenção e o tratamento de muitas, senão todas, doenças humanas.

Resta imaginar de quê morreremos... 


\section{A História dos Testes Genéticos COMEÇA COM O DNA}

O DNA é um grande banco de dados de informações químicas. Localiza-se no núcleo de cada uma das células do corpo humano e carrega o conjunto completo de instruções para a produção de todas as proteínas que uma célula irá necessitar. Ele consiste em duas longas cadeias pareadas e espiraladas formando uma dupla hélice. Cada cadeia é formada de milhões de peças químicas chamadas bases nitrogenadas. Existem apenas quatro bases químicas diferentes no DNA (adenina, timina, citosina e guanina), que podem ser arrumadas de inúmeras maneiras. A ordem na qual as bases estão alocadas determina a mensagem a ser enviada - um pouco como as letras do alfabeto combinam para formar palavras e frases.

Toda célula humana, com exceção das hemácias maduras que não têm núcleo, contém o mesmo DNA. Cada célula contém 46 moléculas de DNA. Cada molécula de DNA é constituída de 50 a 200 milhões de bases hospedadas em um cromossomo.

Um gene é uma subunidade de uma molécula de DNA. Um gene é qualquer segmento ao longo da cadeia de DNA que carrega um conjunto de instruções o qual permite à célula produzir um produto específico tipicamente, uma proteína (geralmente, uma enzima). Existem, ainda não se sabe ao certo, entre 30 e 130 mil genes (evidências apontam para o número menor), e cada gene é constituído de milhares, até mesmo centenas de milhares de bases químicas.

Construir proteínas é uma das funções principais da célula. Para uma célula produzir uma proteína, a informação de um gene é copiada, base a base, de uma fita de DNA para um RNA. O RNA transfere a informação copiada do núcleo para o citoplasma, para a organela celular, chamada ribossomo, onde a síntese da molécula da proteína ocorre. Embora cada célula contenha potencial para produzir todas as proteínas humanas, as células usam os genes seletivamente.

Alguns genes codificam proteínas necessárias para a função celular básica e estes genes permanecem ativos todo o tempo em muitos tipos de 
células. Geralmente, uma célula ativa apenas os genes necessários no momento e suprime os restantes. Uma seleção de genes usados por uma célula confere a ela o seu caráter - uma célula cerebral é diferente de uma célula do osso, por exemplo. Um corpo saudável depende da interação contínua de milhares de proteínas, atuando juntas na quantidade exata e no local exato - cada proteína funcionando apropriadamente é o produto de um gene intacto.

Muitas doenças, talvez a maior parte delas, têm raízes em nossos genes. Mais de 8.500 doenças humanas raras são causadas por mutações em um único gene. Progresso considerável tem sido feito em isolar estes genes. No entanto, existem mais de cem doenças relativamente comuns, cada uma delas atingindo em torno de 0,5\% ou mais da população (exemplos: diabetes, hipertensão, alguns tipos de câncer, osteoporose e asma) que envolvem a interação de um ou mais genes de suscetibilidade e o meio ambiente. A identificação destes genes é mais difícil, porém, eventualmente serão encontrados. O entendimento desse mecanismo possibilitará o adiamento do início da doença e o desenvolvimento de novas drogas para combatê-las.

Os genes podem ser alterados (mutados) de muitas formas. A mudança (mutação) mais comum envolve uma leitura errada do DNA. Outras vezes, uma base é retirada ou adicionada e, mais raramente, pedaços maiores de DNA são repetidos erroneamente ou 'deletados'.

Quando um gene contém uma mutação, a proteína codificada por este gene será provavelmente anormal. Algumas vezes, a proteína poderá funcionar, porém imperfeitamente. Em outros casos, estará totalmente incapacitada. O desfecho dependerá não somente em onde ou como a mutação altera a função protéica mas também em quão vital esta proteína é para a sobrevivência celular.

As mutações podem ser tanto herdadas quanto adquiridas. Mutações herdadas são carreadas no DNA de células reprodutivas. Quando células reprodutivas contendo mutações produzem embriões, a mutação será encontrada em todas as células do embrião. O fato de todas as células conterem o gene mutado torna possível o uso de células ou de amostra de 
sangue para o teste genético. Mutações adquiridas são mudanças no DNA que se desenvolvem durante a vida de uma pessoa. Embora erros aconteçam sempre, especialmente durante a divisão celular, as células têm capacidade notável de corrigi-los. Porém, se o mecanismo de reparo do DNA falhar, a mutação pode passar para gerações futuras por meio de cópias da célula alterada.

As células humanas contêm dois conjuntos de cromossomos (22 autossomos e um cromossomo determinante do sexo, X ou Y), um conjunto herdado da mãe e outro do pai. Os genes vêm em pares, uma cópia de cada genitor. Em um mesmo local (locus), os genes ocorrem em formas variadas, chamados alelos. O efeito de um alelo dominante prevalece sobre o do alelo homólogo. O efeito de um alelo recessivo só se torna aparente se o seu homólogo for igual, tornar-se inativo ou for perdido. Nas doenças genéticas dominantes, um dos pais tem o alelo causador da doença que predomina sobre o seu homólogo normal. As crianças da família têm 50\% de chance de herdar este alelo e, por conseqüência, a doença.

Em doenças associadas com gene recessivo, ambos os pais, embora livres de doença, têm um alelo normal e um alelo alterado. A probabilidade para os filhos herdarem a doença é de 25\%. A maioria das doenças não segue padrões simples de herança. Muitos fatores influenciam os genes na sua capacidade de produzir proteínas. Mutações diferentes no mesmo gene podem produzir efeitos variados. Na fibrose cística, por exemplo, o gene que controla a produção de muco pode ter mais de 300 mutações diferentes, sendo que algumas causam sintomas severos e outras, nenhum sintoma.

Proceder a uma testagem genética significa examinar o DNA de uma pessoa - geralmente extraído de células de uma amostra de sangue - para identificar uma mutação que anuncia uma doença ou desordem química. Alguns testes genéticos podem identificar mudanças envolvendo todo o cromossomo. Outros examinam pedaços curtos de DNA marcadores, dentro ou próximos aos genes, ou ainda procuram por produtos protéicos dos genes.

Os testes genéticos servem a muitos propósitos e são amplamente utilizados em triagens de recém-nascidos para variadas doenças. Estes testes permitem aos casais saberem se são portadores de mutações. Em programas de pesquisa, os médicos estão utilizando testes de DNA para 
câncer ou para estágios pré-cancerosos. Muito da excitação em torno do teste genético nos dias atuais está centrada nos testes genéticos preditivos: testes que identificam pessoas em risco de ter uma doença antes de os sintomas aparecerem.

Identificar genes associados com doenças - na realidade, rastrear toda a base química em cada um dos genes, assim como os espaços entre eles (processo chamado de mapeamento do genoma humano) - é a tarefa de um estudo colaborativo internacional conhecido como Projeto Genoma Humano (HUGO). O HUGO é a mais ampla exploração sistemática, jamais realizada, da biologia humana. É um projeto multinacional que visa a identificar e a determinar as funções de todos os genes humanos. Determinará, em nível molecular, o que constitui um ser humano: cada um é o produto de seu genoma e sua interação com o meio ambiente. $\mathrm{O}$ projeto tem evoluído muito bem em relação às suas metas, sendo que algumas, como o mapeamento ou 'rascunho', foram atingidas antes do tempo estimado e com custos abaixo do orçado. Compreender a base genética das doenças humanas é uma das metas do HUGO.

O impacto na maneira como os seres humanos se vêem será enorme, semelhante ou superior ao causado pelo Origens das Espécies, de Charles Darwin. Será um livro diferente, pois o homem poderá olhar tanto para o passado quanto para o futuro; poderá escrever nele e mudar o futuro.

Para identificar as bases do DNA nos genes, os cientistas começam com o mapa genético, usando marcadores genéticos para orientar a posição do gene ao longo de um cromossomo. Os cientistas clonam ou copiam sítios específicos, obtendo milhões de cópias idênticas, que são estocadas. Quando os marcadores indicam que um gene de interesse se localiza em um clone particular, os cientistas podem recuperar aquele clone e usá-lo para seqüenciamento e identificar a ordem de cada uma das bases químicas no gene estudado.

A procura científica de um gene relacionado à doença começa pela análise de amostras de famílias doentes que tenham história de algumas gerações de pessoas afetadas. Os pesquisadores inicialmente procuram marcadores facilmente identificáveis - segmentos de DNA conhecidos que 
se localizam próximo ao gene da doença e que sejam consistentemente herdados pelas pessoas com a doença e não sejam encontrados nos parentes sem doença. Em seguida, estabelecem o ponto zero na exata localização do gene ou dos genes alterados e, finalmente, caracterizam as bases específicas modificadas.

Antes mesmo da exata localização da mutação ser conhecida, sondas podem ser feitas a partir de marcadores confiáveis. Uma sonda é um pedaço de uma fita única de DNA ligado a uma molécula radioativa e que é capaz de ligar-se a uma área próxima ao gene. Os sinais radioativos são visíveis em filmes de raios-X, mostrando onde o DNA e a sonda se combinam.

A determinação do risco futuro de doença baseada na identificação de genes de suscetibilidade é o escopo do que tem sido chamada de medicina preditiva. Tecnologias vêm sendo empregadas para comparar a seqüência de DNA de um grande número de indivíduos com uma seqüência padrão de muitos genes e revelarão muitas diferenças - a maioria será a variação genética normal, que nos faz diferentes, mas um pequeno número poderá indicar a presença de genes de suscetibilidade. Quando estiver disponível o conhecimento completo dos mecanismos pelos quais essas mudanças genéticas podem resultar em doenças, estratégias para adiar o início da doença e prover melhores tratamentos poderão ser formuladas. Essas estratégias poderão ser mudança de hábitos de vida, tratamentos com drogas ou terapia genética. No mundo todo, a indústria farmacêutica está investindo centenas de milhões de dólares na genômica das doenças.

A tendência da medicina preditiva é progredir no sentido de tratamentos personalizados. Isto requer a determinação de genes de suscetibilidade que o indivíduo tenha para condições não-malignas ou o perfil molecular de células tumorais, comparar com terapêuticas específicas e então desenhar o regime e as doses apropriadas para o polimorfismo nos transportadores de drogas e nas enzimas que as metaboliza (Evans \& Relling, 1999).

Antes do mapeamento ou seqüenciamento do genoma, encontrar um gene era uma tarefa muito laboriosa. Por exemplo, o cromossomo $\mathrm{X}$ frágil foi descrito em 1969, porém só foi isolado em 1991. A doença de 
Huntington, uma doença neurodegenerativa autossômica dominante que se manifesta na idade adulta, caracterizada por distúrbios motores e de personalidade progressivos e que levam à demência, foi mapeada no braço curto do cromossomo 4 em 1983 e o gene (huntingtin) foi encontrado em 1993. O progresso do trabalho do HUGO encurtou esta tarefa: o gene da displasia espôndilo-epifisária tardia foi mapeado em uma região do cromossomo X que foi seqüenciada, a análise da seqüência revelou um bom gene candidato e mutações neste gene foram encontradas em três famílias diferentes menos de um mês após o mapeamento (Gedeon et al., 1999).

Atualmente, o principal fator limitante para o isolamento dos diversos genes que causam doenças monogênicas é a disponibilidade de famílias nas quais estes genes estejam presentes. Muitas dessas doenças são bastante raras e afetam menos de uma pessoa por milhão.

Os genes de suscetibilidade são mais difíceis de encontrar. As doenças que seguem o padrão de herança multifatorial ou poligênica possuem $20 \mathrm{a}$ 30 genes de suscetibilidade que, potencialmente, têm um papel na sua causalidade. Os elementos ambientais são igualmente importantes. Um bom exemplo é o da dependência ao álcool. Uma pessoa suscetível que nunca beba álcool obviamente não se torna alcoólatra.

Os genes de suscetibilidade, importantes em alguns grupos étnicos, não são relevantes para outros. Os genes que conferem alto risco de suscetibilidade são fáceis de encontrar. Os genes de suscetibilidade para câncer de mama BRCA1 e BRCA2 são bons exemplos. Eles conferem um risco de 50 a 80\% de desenvolvimento de câncer de mama durante a vida, comparado com o risco de $9 \%$ da população. No entanto, são responsáveis por menos de 10\% dos cânceres de mama. Genes que aumentam pouco o risco populacional são mais difíceis de encontrar.

Testes genéticos preditivos já estão disponíveis para cerca de cem doenças. Também foram encontrados genes para diversos tipos de câncer e testes para alguns tipos já estão em uso clínico. Todos os cânceres são genéticos, isto é, provocados por genes alterados. Os genes que controlam a replicação ordenada das células são danificados, fato que permite à célula reproduzir-se sem restrição. O câncer geralmente surge em uma única 
célula. O progresso da célula de normal para maligna e, em seguida, para metastática parece obedecer uma série de etapas distintas, cada uma controlada por um gene diferente ou por um conjunto de genes.

Apesar de todo câncer ser genético, talvez apenas uma pequena porção (5 a 10\%) seja hereditária. Muitos cânceres surgem de mutações ao acaso que se desenvolvem nas células corporais durante a vida, a partir de erros durante a divisão celular ou em resposta a agressões ambientais - irradiação ou agentes químicos, por exemplo.

Os testes genéticos encontram mutações e não doenças. Um teste genético pode dizer se uma mutação está presente, porém este achado não garante que a doença se desenvolverá. Por exemplo, mulheres com o gene de suscetibilidade ao câncer de mama (BRCA1) têm 80\% de chance de ter um câncer de mama aos 65 anos de idade. O risco é alto, mas não é absoluto. Os membros da família que apresentem teste negativo para a mutação BRCA1 não estão isentos de risco para câncer de mama e podem adquirir câncer provocado por outras mutações na mesma proporção da população geral.

A testagem genética oferece alguns benefícios. Um teste negativo pode criar uma sensação de enorme alívio e pode eliminar a necessidade de check-ups freqüentes, que são parte da rotina de famílias com alto risco de câncer. Mesmo um teste positivo é capaz de causar alívio pela eliminação da incerteza e permite ao paciente a decisão informada sobre o futuro. Tem o efeito, ainda, de levar o paciente a tomar providências para a redução do risco antes de a doença aparecer.

Porém, os testes genéticos apresentam várias limitações. Por exemplo, algumas doenças que cursam em famílias podem ser devidas a exposições ambientais compartilhadas e não a suscetibilidades herdadas. Além disso, algumas mutações detectadas por um teste positivo podem nunca levar à doença. E mais ainda: os testes existentes procuram apenas as mutações mais comuns nos genes e algumas doenças são provocadas por mutações que escapam à detecção.

Talvez a mais séria limitação dos testes genéticos esteja no fato de que a informação não acompanha os avanços na terapia e diagnose. Receber 
um resultado positivo quando não se dispõe de tratamento pode ser trágico. Embora a testagem genética ofereça pequeno risco físico, não mais do que a coleta de uma amostra de sangue pode afetar seriamente a vida de uma pessoa. Um teste confirmando o risco de uma doença séria pode desencadear conseqüências psicológicas graves.

A questão dos benefícios, das limitações e das conseqüências dos testes genéticos não é pacificada. Braz (2001) discute em profundidade este tema. Uma vez que os testes revelam informações não apenas do indivíduo, mas também de seus parentes e futuros descendentes, os resultados podem ameaçar as famílias e outros parentes. Com quem se deve compartilhar os resultados? Outros membros da família devem ou querem saber?

Confidencialidade é uma preocupação importante. Nos Estados Unidos e na Austrália, por exemplo, algumas pessoas já têm sido recusadas por planos de saúde, têm perdido empregos ou promoções e, até mesmo, têm sido recusadas para adoção com base em resultados de seu status genético (Braz, 2001).

A decisão de fazer o teste é pessoal e deve ser totalmente voluntária. Após o aconselhamento genético, a pessoa deve concordar com a realização do teste apenas se quiser e não para acomodar preocupações de parentes, seguradoras ou qualquer outro interesse. Uma consideração importante para pesar é: se o teste for positivo, há possibilidade de detecção precoce, prevenção ou tratamento da doença?

O aconselhamento genético tem papel vital. Especialistas treinados estão habilitados para apoiar indivíduos quando está em consideração a realização do teste, quando os resultados são conhecidos e durante as semanas e meses que seguem o resultado.

Uma vez que os testes preditivos são desenhados para identificar pessoas que tenham uma mutação genética, os primeiros candidatos para estudos são os membros de famílias de alto risco. Mais tarde poderão ser oferecidos para pessoas cujas famílias sejam menos informativas. Não está longe de ser possível a realização de vários testes para mutações em amostras de sangue, semelhante ao teste do pezinho. Antes de os testes 
preditivos se tornarem disponíveis em larga escala, os especialistas e a sociedade devem enfrentar a discussão das preocupações técnicas, éticas e econômicas. Se a difusão ampla dos testes se tornar realidade, será necessário o desenvolvimento de testes simples, custos efetivos e acurados. Testes de milhões de pessoas requererão muitos laboratórios e pessoal especializado, assim como um número muito maior de pessoal treinado em aconselhamento genético. Outro requisito importante: os médicos devem compreender os princípios de genética clínica e aplicada para interpretar os testes corretamente.

Após estas considerações técnicas e algumas questões éticas associadas aos avanços genéticos e aos testes preditivos, o foco deste trabalho se fixará no que se denomina sociedade pós-genômica: um futuro indeterminado, embora inevitável, no qual se prevê uma descrição do que todos os nossos genes fazem; quais mutações provocam doenças; como e quais genes interagem para causar patologias; como as variações normais contribuem para doenças e qual é a participação do ambiente no fenótipo dos indivíduos. Na sociedade pós-genômica, os indivíduos terão acesso a determinações individuais de risco probabilístico durante a vida para a maioria das doenças.

\section{Breves Considerações sobre o Problema Econômico dos Testes Preditivos}

À medida que o conhecimento evolui, a demanda por testes genéticos deve aumentar, particularmente para testes pré-natais, screening de portadores e testes preditivos. As principais variáveis a serem consideradas são: a educação do público, a magnitude do risco, a severidade das conseqüências da doença, a possibilidade de intervenção, os fatores culturais e o custo para o consumidor.

Nas populações de risco nos países desenvolvidos, geralmente bemeducadas, onde já estão disponíveis programas de testagem com rápido acesso garantido, um número surpreendente de jovens (por exemplo, com risco de 50\% para Huntington) já fez seu teste preditivo (Turner et al.,1997). 
O custo atual de um teste preditivo para doença de Huntington é de US\$ 250; para o gene BRCA1, de US\$ 1.250. Embora as técnicas mais modernas possam diminuir os custos unitários, parece inevitável que a demanda aumentada pelos testes causará um substancial aumento nos custos da oferta destes testes (mais baratos, mais testes, mais despesas). Quando a estratificação do risco estiver disponível, é provável que a demanda se justifique e supere o problema econômico. Por exemplo: um indivíduo que apresente um polimorfismo herdado indicativo de risco aumentado para doença coronariana poderá realizar estudos hemodinâmicos antes da idade em que eclodiria a doença e adotar medidas preventivas mais eficazes.

Parece também inevitável que opções de tratamento e demanda de tratamento profilático aumentarão com o crescimento exponencial do conhecimento sobre os mecanismos moleculares geradores de doença. Algumas vezes, o tratamento profilático exigirá apenas mudanças de hábitos, com mínimos custos agregados; outras vezes, como na doença de Gaucher, ${ }^{1}$ o tratamento implica em uso, por toda a vida, de enzimas suplementares, com custos elevados.

Os testes pré-natais para defeitos congênitos são bem-difundidos e têm grande utilização. Não parece que se terá grande aumento na sua utilização, nos países onde se permite a interrupção de gestação por defeitos congênitos. No entanto, o segmento de testes para doenças que eclodirão na vida adulta, ainda com utilização baixa, deverá experimentar uma demanda crescente e conseqüente pressão dos custos sobre o sistema de saúde e seguradoras, assim como já desencadeou uma série de questionamentos éticos. Será válido fazer um teste preditivo para câncer de mama em embriões? Se o teste der positivo, éjusto e moralmente correto abortar neste caso? A questão colocada refere-se a algo que não é e não pode ser mais facilmente decidido, como nos casos de malformações incompatíveis com a vida, por exemplo. Será justo não deixar nascer uma criança por ela ser portadora de uma mutação que poderá ou não se expressar? Não estaremos limitando demais a ocorrência de uma doença em função do aspecto econômico? Na sociedade indolor na qual se vive, 
será válido, em nome do não-suportamento do sofrimento, não deixar vir ao mundo uma pessoa que poderá ter uma doença que pode ser tratada e curada se descoberta a tempo?

À medida que fique mais bem-definido o papel da genética na etiologia das doenças e o desenvolvimento da farmacogenômica e de técnicas de diagnóstico, podemos esperar redução de iatrogenias e redução das despesas em longo prazo, já que, em curto prazo, os exames ainda serão muito onerosos.

A expectativa de vida tem aumentado de forma importante nos últimos anos e espera-se que atinja um platô máximo natural ainda não atingido. Nos países desenvolvidos, a velocidade do incremento da expectativa de vida tem sido inversamente proporcional à alocação de recursos em saúde. Nos países pobres, o problema se agrava com o duplo fardo resultante da ainda não resolvida doença transmissível e do aumento da expectativa de vida que também cresce. Nos países desenvolvidos, estima-se que, para cada ano de vida a mais na expectativa de vida, o resultado é um incremento de cerca de 5\% no índice de dependência (a relação da população de mais de 65 anos com a de trabalhadores ativos de 15 a 64 anos). As doenças degenerativas poderão, com o aprimoramento de técnicas de regeneração de tecidos (transplantes autólogos, célulastronco, entre outras), ser curadas.

Células não-humanas perenizadas já podem ser manipuladas para obtenção de produtos com a constituição genética desejada. Se essas técnicas forem combinadas em células humanas com clonagem, será possível fabricar seres humanos sob encomenda. Seria tolice pensar que não existem barreiras técnicas ainda numerosas para se conseguir este objetivo, assim como uma imensa barreira ética e moral. Porém, a tecnologia existe, e a sociedade deve continuar o debate sobre a possibilidade de redefinição genética do ser humano. Como escreveu Parker (1994: 138): "Não se deve ignorar o impacto que a genética preditiva terá na sociedade e nem a reação da sociedade a ela". E afirmou que "um aspecto saudável da 'bioética preventiva' antecipa problemas que poderão ser mais facilmente prevenidos que curados". 


\section{Os Dilemas Morais e Filosóficos e a Aplicabilidade do Princípio da Protecão}

Os indivíduos que terão conhecimento de seu futuro viverão experiências que a humanidade ainda não vivenciou. Como será viver com a certeza de que progressivamente perderemos uma função primordial como, por exemplo, motora ou mental? Na verdade, se trará para o presente os problemas futuros. Esse conjunto de problemas será certamente comum na sociedade pós-genômica e requer uma redefinição das obrigações que tais conhecimentos e técnicas criarão.

A sociedade produziu leis, regras, direitos, normas de justiça e códigos nas relações humanas baseados em contratos que não previam certeza do futuro. A informação genética pode mudar esta situação. O indivíduo que sabe algo de seu futuro é diferente? Essas pessoas têm a capacidade de julgamento comprometida? Têm obrigações e deveres morais diferentes daquelas que não conhecem ou não querem conhecer seus futuros? Um indivíduo pode ser punido pelo seu genótipo e não pelo seu fenótipo?

Saber o próprio destino genético pode ser um direito autônomo mesmo que os recursos necessários para obter esta informação sejam muito custosos para a sociedade? Tem-se aqui um conflito entre o princípio da autonomia e o da justiça. O conhecimento do futuro em saúde é uma informação privada. Porém, o respeito à autonomia implica também uma certa reciprocidade, desde que não afete outras pessoas, como se discutirá a seguir.

Há obrigação de compartilhar esta informação com terceiros envolvidos? Podemos considerar como moralmente não recomendável um indivíduo que sabe, por exemplo, que é portador de doença de Huntington e não informa ao possível parceiro? No escopo da lei, uma pessoa que esconde uma doença grave de seu cônjuge pode ter o casamento anulado. Fora do domínio privado, quais as obrigações em termos de compartilhamento de informações com os parceiros comerciais, empregadores ou companhias de seguros? Uma pessoa pode interagir lealmente sem compartilhar tais informações? Em muitos casos, os testes genéticos não serão tão dramáticos como na doença de Huntington. O que esperar de uma pessoa que toma 
conhecimento de sua condição de portador de um risco ou uma certeza de doença?

Uma companhia de seguros é uma empresa de mútuo que compartilha riscos e oportunidades e representa um interesse legítimo da comunidade. Quando alguém contrata um seguro, a informação genética é um fator importante cuja omissão poderá invalidar cobranças futuras de prêmios. Preservar o conhecimento do risco de futuras doenças em nome da autonomia individual deixa os outros indivíduos, que fazem parte do mesmo grupo de mútuo, em desvantagem. Novamente, aparece uma tensão entre autonomia individual (segredo) e justiça distributiva.

A possibilidade de uso da informação genética é uma questão inquietante por várias razões. Obter uma informação que poderá levar o indivíduo a uma posição de inferioridade ou mesmo ser discriminado é um impeditivo para a realização do teste que o poderia beneficiar (adiar o início de sintomas, mudar alguns hábitos, tratamento profilático). Considerandose que todos, de certo modo, estão sujeitos à predisposição genética, pode-se apontar que a discussão do problema dos discriminados está ocorrendo antes do problema de todos.

Tais expectativas e suas conseqüências estão de modo inextrincável ligadas a como a sociedade enxerga a loteria natural da herança. Respondendo a essa questão, filósofos tendem a adotar campos opostos. Interpretações deontológicas do segundo princípio da justiça de Rawls (1997) defendem que a sociedade tem como obrigação procurar redirecionar iniqüidades, quando possível, e acreditam que a redistribuição de bens primários pode ser justificada com essa finalidade. No primeiro princípio, acerca do desejo universal de que esteja disponível para todos a máxima quantidade de liberdade e bens primários, Rawls (1997) preconiza o véu da ignorância (veil of ignorance), que confronta com pré-ciência, e discute se esta limita a capacidade de tomar decisões justas. Bioeticistas como Engelhardt (1998: 455) defendem que a loteria natural é apenas isso, uma loteria moralmente neutra: "[a] loteria natural cria desigualdades e coloca indivíduos em desvantagens, sem criar uma obrigação moral secular direta de parte dos outros em ajudar aqueles que têm necessidades". 
Vive-se numa sociedade na qual as iniqüidades abundam e onde a aquisição econômica e o culto do individualismo prevalecem. A autoridade moral para induzir ou forçar o redirecionamento das iniqüidades é severamente limitado (Turner, 2000). A posição de Turner o aproxima dos defensores da tese do neolítico moral, a qual defende a noção de que os problemas da humanidade têm origem na existência de uma grande disparidade entre, de um lado, os progressos científico, tecnológico e econômico e, de outro, a falta de desenvolvimento ético. Tese que se baseia em um conceito negativo com ênfase no atraso moral dos homens, isto é, os seres humanos carecem de maturidade ética. Esta concepção olha para o que falta e não para o que existe.

Será que se pode concordar com este postulado? Pode-se esperar que em uma sociedade tão fixada em imagens de pseudoperfeição humana ocorrerá uma tomada de consciência de que o que verdadeiramente caracteriza o ser humano é sua imperfeição? Celebrar a individualidade sem discriminação pode ser difícil em uma sociedade pós-genômica, o que aparentemente reforça a tese de Turner (2000).

Parece inevitável que os excluídos genéticos formarão um novo grupo de pessoas atingidas, indesejáveis pelos agentes públicos e privados de saúde, aumentando o contingente de pessoas discriminadas. A proposta de Schramm e Kottow (2001) para dar conta deste problema, no campo da saúde pública, em sociedades complexas e pobres, é o princípio da proteção.

Em seu trabalho fundador que introduz este princípio como proposta alternativa para dar conta das necessidades sanitárias coletivas, especialmente nos países latino-americanos, os autores afirmam que, uma vez que ele seja aceito, se terá justificado submeter, inevitavelmente, a autonomia individual aos interesses do bem-estar coletivo:

As políticas de proteção de saúde pública aparecem como propostas frente a necessidades sanitárias coletivas. Uma vez aceitas, se tornam obrigatórias e permitem que o cumprimento das medidas de proteção justifique exercer um legítimo poder de disciplina e autoridade para que sejam efetivas. Também se justifica submeter a autonomia individual aos requisitos do 
bem-estar coletivo, a princípio sem contemplar exceções. A legitimidade das ações sanitárias e a inevitável restrição da autonomia individual constituem características dos atos protetores, a proteção adquire assim uma forma de poder sui generis, avalizado pelo princípio da responsabilidade e caracterizado, como assinalado, pela postergação das obrigações frente ao indivíduo. Quer dizer, a justiça sanitária prevalece sobre a autonomia individual. (Schramm \& Kottow, 2001: 954)

Pode-se dizer que o pensamento destes autores se alinha com a tese da ética como fator de coesão social e baseia-se num conceito afirmativo. Afirma que a presença e a importância de atributos de natureza ética são determinantes da capacidade de sobrevivência comunitária dos indivíduos, das empresas e das nações. Ênfase não no que falta, mas no que conta: a ética que importa e faz diferença.

Diferentemente da tese do neolítico moral, não se trata de uma avaliação negativa e sim de uma análise positiva da ética como fator de coesão social. Contém dois núcleos temáticos: o valor para a sobrevivência e coesão social da moralidade e a relação entre ética, comportamento individual e eficiência coletiva. Aponta para as tensões e os imperativos conflitantes: moralidade cívica versus pessoal e racionalidade individual versus coletiva.

Resta claro, porém, que a proposta carrega um excesso de autoridade. À ficção hobbesiana do estado de natureza é preciso contrapor a imagem do rebanho nietzchiano. Existe uma tensão perene entre moralidade cívica que garante a sobrevivência e a ordem social, de um lado, e a moralidade pessoal que expressa a liberdade do indivíduo e dá valor à sobrevivência, de outro. Se o colapso da primeira leva à anarquia troglodita da metáfora de Montesquieu (2003), retratada nas Cartas Persas, o enfraquecimento da segunda é o caminho para o niilismo do formigueiro humano retratado na metáfora da colméia de Mandeville (2003), uma ordem estável, é verdade, porém rígida, mecânica e desprovida de valor.

Por diferentes razões e caminhos, filósofos como Nietzsche, Mill, Tocqueville e Russel desenvolveram argumentos contra a hipertrofia da 
moralidade cívica e o abuso do poder. Sob a diversidade motivacional e retórica de seus argumentos, podemos identificar uma premissa comum: a afirmação moral do indivíduo, mais precisamente a atribuição de significado metafísico especial à capacidade de escolha com a qual o ser humano é singularmente dotado (Giannetti, 2002).

Se numa situação de guerra ou emergência coletiva a imposição de restrições à liberdade individual ocorre por se tratar de condição de sobrevivência para a comunidade, então ela se justifica. Mas em condições normais, mesmo que adoção signifique a promoção do conforto, não se justifica, resulta em um "sobreviver insípido em condição indolor de conforto" (Giannetti, 2002: 104).

Outro tipo de objeção é de natureza econômica. Quais são as conseqüências práticas do coletivismo? A resposta, qualquer que seja ela, dependerá de um argumento econômico. Qualquer sistema econômico representa uma resposta aos desafios da escassez e da escolha. O problema econômico da comunidade reside na disparidade entre essas necessidades e esses desejos, por um lado, e os meios disponíveis para satisfazê-los, por outro. Se não existisse a escassez, desapareceria o problema econômico. Se não houvesse desejo e escolha, muitos morreriam de tédio, viveriam como insetos sociais, presos a padrões biológicos de existência e reprodução.

A existência simultânea de escassez e de escolha é um fato da condição humana. A coordenação, ou seja, como os indivíduos e instituições se ajustam uns aos outros, é a dimensão na qual se pode procurar a ordem. Existem dois tipos básicos de resposta ao problema da coordenação: o Estado e a sociedade (mercado). Schramm e Kottow (2001) optaram pelo Estado: "O Estado deve assumir obrigações sanitárias que implicam uma ética da responsabilidade social correspondente, que chamamos aqui de ética de proteção".

Pode-se encontrar no pensamento de Smith (2002: 292) uma reflexão importante:

O homem do sistema [o planejador estatal] costuma se achar muito sábio em seu próprio juízo; e ele está com freqüência tão enamorado da suposta beleza de seu próprio plano ideal...Ele 
pode imaginar-se capaz de dispor os diferentes membros de uma grande sociedade com a mesma facilidade com que a mão dispõe as diferentes peças sobre um tabuleiro de xadrez. Ele não considera que as peças sobre um tabuleiro de xadrez não possuem qualquer outro princípio de movimento além daquele que a mão confere a elas; mas que, no grande tabuleiro de xadrez da sociedade humana, cada peça tem por si mesma um princípio de movimento que lhe é próprio.

Assim, as tentativas do governo de interferir, manipular e dirigir as atividades de empresas e indivíduos implicam algum grau de coerção e acabam gerando ineficiência, redução do bem-estar e dos efeitos inesperados. Por outro lado, sugeriu Smith, estava o sistema no qual os indivíduos são livres para tentar satisfazer seus objetivos, à luz de seus próprios recursos e conhecimentos. Como se organizará a sociedade pós-genômica? A proposta de Schramm e Kottow (2001) será viável se houver consenso em torno de algumas questões que são levantadas no sentido de abrigar o grupo de excluídos agora reforçado pelos parias genéticos, as quais serão discutidas a seguir.

Em suas conclusões, Schramm e Kottow (2001) propõem: "A avaliação pode melhor realizar-se a partir de um princípio de proteção, o qual impõe o dever de eficácia como condição necessária para um postulado legítimo de intervenção, autorizada para exigir à autonomia pessoal que se ajuste ao bem comum".

Esta afirmativa conduz ao Diálogo em Torno da República, de Norberto Bobbio e Maurizio Viroli (2002: 48), no capítulo em que discutem direitos e deveres. Bobbio, sobre o princípio do bem comum, indaga: "No que consiste o bem comum? É o bem da coletividade ou o bem do indivíduo?" Viroli sustenta que "o bem comum não é nem o bem (ou o interesse) de todos, nem um bem (ou um interesse) que transcende os interesses particulares". E prossegue, apoiando-se em Maquiavel: "Jamais cultivou a idéia de uma comunidade orgânica, na qual os indivíduos operem em vista do bem comum, e nem tampouco perdeu tempo fantasiando repúblicas onde as deliberações soberanas são aprovadas por unanimidade graças às virtudes dos cidadãos." Mais adiante, provocando seu interlocutor: "o bem comum 
é um conceito retórico, no sentido de que não é um critério que possa ser demonstrado de modo incontestável." E termina com a provocação: "Mas se você quiser exortar os governos a buscar o bem comum, fico bem feliz."

Pode-se dizer que todos também ficarão bem felizes se o aprofundamento do princípio da proteção resultar em uma ferramenta possível de ser utilizada para superar os dilemas colocados pela sociedade pós-genômica que se avizinha. Esta é uma questão difícil de ser levada a cabo, existindo entre estas duas posições inúmeras outras. Entre elas, algumas se destacam.

Walzer (2001: 86), condenando a existência de um acúmulo de riqueza com necessidades em busca de satisfação, diz que: "homens e mulheres que se apropriam de grandes somas de dinheiro para beneficio pessoal, e que continuam com as necessidades sem serem satisfeitas, agem como tiranos, dominando e deturpando a distribuição de previdência e bem-estar". Por este motivo - a possibilidade de se cometer injustiças na previdência e no bemestar -, este autor acha justificável "a coação por parte do Estado para defender o cumprimento do contrato social, entendido como vínculo moral de benefícios mútuos" (Walzer apud Schütz, 2003: 88). Isto porque há uma minoria que não consegue perceber quais são seus interesses de fato reais e que somente "o insensível e o imprudente necessitam ser obrigados a contribuir, e poderia ser afirmado que estes indivíduos necessitam ser incorporados ao pacto social precisamente para serem defendidos de sua própria insensibilidade e imprudência" (Walzer, 2001: 91).

Nesse sentido, para Walzer (2001), o mercado continua sendo o principal oponente da esfera da necessidade, mas ele não se esquece de que existem interesses de ordem política, como também burocráticos e corporativos, em relação à organização e ao modo de administrar os recursos previdenciários e os do bem-estar. A solução para este autor é a participação ativa dos cidadãos "nas questões relativas ao bem-estar [e] se propõe [a] evitar o predomínio do poder político na esfera da necessidade" (Walzer, 2001: 105).

Também é importante ressaltar, neste ponto, que se deve continuar tentando soluções, pois o papel da Bioética não deve ser puramente analítico 
e descritivo. Cabe à Bioética, de igual modo, prescrever, opinar sobre o que é moralmente melhor ou o menos pior. Não se pode mais ignorar que os recursos são escassos e as demandas são infinitas. Como postula Callahan (1990: 169): "Tudo indica que a pressão para controlar os custos será ainda maior no futuro e que haverá uma discussão muito mais direta e franca sobre seu racionamento".

Paralelamente ao aumento significativo dos gastos em saúde durante a década de 1970, principalmente em seu término, foram empreendidos esforços para buscar uma saída eficaz e ética para reduzi-los. "Tanto na prática quanto na teoria, admite-se que é preciso estabelecer limites na alocação de recursos para a atenção sanitária" (Callahan, 1990: 169). Em outro trabalho, Callahan (1998) afirma que, nos Estados Unidos, existe uma crença no progresso que levam os indivíduos a buscarem uma utopia da 'saúde perfeita' (Sfez, 1996). Para Callahan (1998), isto é uma fórmula certa para a falência do sistema de saúde e propõe, em função disto, uma medicina sustentável e um aumento da responsabilidade pessoal com a própria saúde. Os objetivos atuais da medicina acabam por se constituir em utopias, já que seu conhecimento parece estar a serviço do desejo humano de resolver problemas para os quais não há e nem haverá soluções, tais como: a eliminação total das doenças, o melhoramento do desempenho mental e o prolongamento da vida.

Schramm (2000: 41) advoga que os:

sistemas de saúde com vocação universalista não podem incorporar despesas indefinidamente, sob o risco de irem à falência; e, ao mesmo tempo, não podem ignorar a sua vocação universalista fundamentada na integridade da atenção médicohospitalar, principalmente para não perder sua identidade e legitimidade.

Isso quer dizer que a cultura dos limites, preconizada por Callahan, se caracteriza pela:

escassez de recursos e a crescente demanda que obriga a racionalizar os encargos sanitários -, o respeito do princípio 
da justiça distributiva implica em ter que se optar entre políticas de universalização (que deve fornecer todos os serviços disponíveis a todos os que precisam deles) e políticas de focalização (que deve decidir o que fornecer e para quem). (Schütz, 2003: 114)

Schramm (2000: 42) acredita que ambas as políticas detêm aspectos bons e ruins, porque:

a solução universalista tem o mérito de respeitar o princípio de justiça entendido como igualdade de oportunidades, mas tem o defeito de desconhecer as diferenças de condição entre indivíduos e classes sociais, além de não poder oferecer todos os serviços para todos (...). A solução focalizadora tem o mérito de considerar as críticas movidas à primeira solução e de aplicar o princípio de justiça entendido como eqüidade (tratar igualmente os iguais e desigualmente os desiguais), mas tem o defeito de introduzir um fator de 'discriminação', que contradiz o direito universal à assistência.

Este debate deve ter como norte a questão ética, isto é, de que modo podem ser distribuídos de forma justa os recursos em função da existência de limitações orçamentárias, o que produz, inevitavelmente, o nãoatendimento de algumas demandas. Esta é a questão que se deve confrontar: quem vai se beneficiar das novas tecnologias? Coloca-se, assim, a necessidade de se priorizar e escolher, o que não é uma tarefa fácil (Schramm, 2000).

Como já visto, o papel da Bioética não é só analisar e descrever. Ela também prescreve e, por este motivo, Schramm afirma que a Bioética também tem uma função protetora no sentido de defender os interesses legítimos dos envolvidos em um conflito, como é o de quem se beneficiará das novas tecnologias - todos (universalização) versus alguns (focalização) (Schramm, 2002).

A tentativa de tentar agradar a todos, de forma universal, mostrase cada vez mais impossível. O princípio da proteção aponta para isto, no sentido de universalizar a prevenção e focalizar os gastos públicos para a parcela menos favorecida e excluída da sociedade. Ao se reportar aos testes 
preditivos, percebe-se que eles carreiam, no momento, mais danos do que benefícios. Danos porque, para a maioria das doenças genéticas, não há ainda solução terapêutica e o gasto para detectar mutações de uma parcela pequena da população ainda é muito alto, o que se configura como um custo muito elevado para o benefício. Há prioridades a serem levadas em conta em países com graves problemas de saúde pública ainda não resolvidos.

A proposta do princípio da proteção não é simpática e seus autores parecem não desconhecer este fato. À Bioética não cabe este papel, mas sim o de alertar para a inviabilidade de certos preceitos populistas que têm tudo a ver com a política, mas muito pouco com a ética.

NOTAS

1 Na doença de Gaucher, o paciente não fabrica a enzima glicocerebrosidase, necessária para a digestão do lipídio glicocerebrosídeo que se acumula progressivamente nas células, principalmente do fígado, do baço e da medula óssea. A suplementação enzimática é feita com 'Alglucerase' (Genzyme, 2004).

\section{ReFERÊNCIAS BiBliOgRÁfICAS}

BObBiO, N. \& VIROLI, M. Diálogo em Torno da República. Rio de Janeiro: Campus, 2002.

BRAZ, M. Aceitação pragmática, otimismo utópico ou reflexão sistemática? nanobiotecnologia, ética, psicanálise... e os testes preditivos de câncer de mama, 2001. Tese de Doutorado, Rio de Janeiro. Instituto Fernandes Figueira, Fundação Oswaldo Cruz.

CALLAHAN, D. Tendencias actuales de la ética biomédica en los Estados Unidos de América. In: Bioética: temas y perspectivas. Washington: OPS, 1990 .

CALLAHAN, D. False Hopes: why America's quest for a perfect health is a recipe for failure. New York: Simon \& Schuster, 1998. 
CLINTON, B. White House Press Conference, 2000. Disponível em: http:// www.whitehouse.gov/WH/New/htm1/genome-20000626.htm. Acesso em: 24 nov. 2002.

ENGELHARDT JR., H. T. Fundamentos da Bioética. São Paulo: Loyola, 1998.

EVANS, W. \& RELLING, M. V. Pharmacogenomics: translating function genomics into rational therapeutics. Science, 286: 487-491, 1999.

GEDEON, A. K. et al. Identification of the genome (SEDL) causing X-linked spondylepiphyseal dysplasia tarda. Nat Gen, 22: 400-404, 1999.

GENZYME. O que é a Doença de Gaucher? Disponível em: http:// www.genzyme.com.br/thera/cz/br_p_tp_thera-cz.asp. Acesso em: 26 mar. 2004.

GIANnetTI, E. Vícios Privados, Benefícios Públicos. São Paulo: Companhia das Letras, 2002.

MANDEVIlle, B. The Fable of the Bees; or, Private Vices, Publick Benefits (1714). Disponível em: http://www.artsci.wustl.edu/ landc/html/ mandeville.html. Acesso em: 22 out. 2003.

MONTESQUIEU, C. S. Lettres Perseanes, lettre XI a lettre IV. Disponível em: htpp:/un2sg4.unique.ch/Athena/Montesquieu/mon_1p_011.html. Acesso em: 28 out. 2003.

PARKER, L. S. Bioethics for human geneticists: models for reasoning and methods for teaching. American Journal of Human Genetics, 54: 137-144, 1994.

RAWLS, J. Uma Teoria da Justiça. São Paulo: Martins Fontes, 1997.

SCHRAMM, F. R. Bioética, economia e saúde: direito à assistência, justiça social, alocação de recursos. Revista Brasileira de Cancerologia, 46(1): $41-47,2000$.

SCHRAMM, F. R. Bioética de la protección del embrión humano, de la reproducción asistida y de la propiedad y transformación del genoma humano. Una perspectiva laica. In: SEMINARIO INTERNACIONAL BIOÉTICA Y FAMILIA: LOS LÍMITES DE LA VIDA HUMANA. Santiago de Chile, 14 nov. 2002. 
SCHRAMM, F. R. \& KOTTOW, M. Bioethical principles in public health: limitations and proposals. Cadernos Saúde Pública. [on-line], 17(4): 949956, 2001. Disponível em: http://www.scielo.br/scielo.php?script= sci_arttext\&pid=S0102-311X2001000400029\&lng =en\&nrm $=$ iso. Acesso em: 20 mar. 2004.

SCHÜTZ, G. E. Quando o "igual tratamento" acaba em injustiça: um paradoxo bioético das políticas sanitárias universalistas de alocação de recursos, 2003. Dissertação de Mestrado, Rio de Janeiro: Escola Nacional de Saúde Pública/Fundação Oswaldo Cruz.

SFEZ, L. A Saúde Perfeita: crítica de uma nova utopia. São Paulo: Unimarco e Loyola, 1996.

SMITH, A. Teoria dos Sentimentos Morais. São Paulo: Martins Fontes, 2002.

TURNER, D. R. et al. Predictive testing for Huntington's Disease in a highly serviced population (South Australia). 17 $7^{\mathrm{TH}}$ INTERNATIONAL MEETING WORLD FEDERATION OF NEUROLOGY RESEARCH GROUP ON HUNTINGTON'S DISEASE. Sydney, Australia, 1997.

TURNER, D. 2000, Post-Genomic society: brave new world or brave new world?, 2000. Disponível em: http://www.ssn.flinder.edu.au/soci/ staff/riaz/genomeproject/2.htm. Acesso em: 18 mar. 2004.

WALZER, M. Las Esferas de la Justicia: una defensa del pluralismo y la igualdad. México: Fondo de Cultura Económica, 2001. 


\section{Bió́tica e Neonatologia}

\section{0}

Carlos Dimas Martins Ribeiro

\section{INTRODUCÃO}

A neonatologia é o campo da medicina que se ocupa da saúde e do desenvolvimento dos recém-nascidos (suas doenças, seus diagnósticos e seus tratamentos), prestando cuidados médicos e preventivos desde o nascimento até o $28^{\circ}$ dia de vida da criança (período neonatal) (Rey, 2003). Na década de 1960, foi introduzida como área de atuação específica da pediatria, tornando-se, nas décadas de 1970 e 1980, um ramo da medicina intensiva (Svenningsen, 1992).

A medicina intensiva originou-se da medicina americana na metade do século XX, passando por extraordinário desenvolvimento nos últimos 20 anos (McCullough, 1998). Trata-se do campo da prática médica que objetiva a atenção aos "pacientes que estão extremamente doentes, cuja condição clínica é instável ou potencialmente instável [constituindo] uma ameaça imediata ou potencial à vida" (Society of Critical Care Medicine, 1999: 1). No caso da medicina intensiva neonatal, incluem-se, nessa condição, recém-nascidos prematuros e/ou com patologias congênitas. Em termos institucionais, tal prática se organiza na Unidade de Tratamento Intensivo Neonatal (UTI Neonatal).

Neste artigo, são abordadas duas questões éticas que preocupam diariamente os profissionais da saúde que trabalham nas UTIs Neonatais: a alocação de recursos em medicina intensiva e a tomada de decisão relativa 
às tecnologias que sustentam a vida. Estas questões são discutidas aqui a partir das opiniões emitidas por médicos e enfermeiros intensivistas (profissionais que trabalham nas UTIs), entrevistados, em virtude de pesquisa realizada (Ribeiro, 2003). ${ }^{1}$

\section{A Alocacão de Recursos em Medicina lntensiva Neonatal}

Na percepção dos intensivistas, os recursos disponíveis para a atenção intensiva neonatal não são suficientes no sentido de atender a todos os recém-nascidos que dela necessitem. Incluem-se, entre os recursos insuficientes, tanto o número de UTIs Neonatais disponível quanto a quantidade de leitos, equipamentos, materiais de consumo, além dos recursos humanos de que dispõem para funcionar de forma satisfatória. A principal causa do descompasso entre a oferta e a demanda nessa área de assistência deve-se a um elemento da primeira - a ampliação da capacidade tecnológica da medicina de recuperar recém-nascidos extremamente doentes - e um componente da segunda - a ausência de assistência pré-natal adequada, que poderia evitar os problemas decorrentes da prematuridade, apontada como a principal causa de internação nas UTIs analisadas.

Os profissionais identificam duas formas de desperdício na aplicação dos recursos públicos para a atenção intensiva neonatal. A primeira é que uma quantidade significativa de recursos excedentes é alocada nessa área de assistência para atender a recém-nascidos prematuros, gerados por mulheres que não tiveram acesso ao pré-natal. Dessa forma, produz-se uma sobrecarga econômica no sistema de atenção à saúde, drenando recursos para as tecnologias de alto custo quando se poderia gastar menos recursos para evitar que recém-nascidos venham a precisar de atenção intensiva. Os recursos seriam aplicados de forma mais produtiva se fosse oferecido um pré-natal adequado a todas as gestantes dentro de um sistema de atenção à saúde integrado e hierarquizado (Goodman, 2001).

Como segunda fonte de desperdícios, os profissionais apontam que uma parte dos recursos é aplicada em recém-nascidos que poderiam ser 
atendidos em unidades menos custosas. Assim, muitos pacientes são atendidos nas UTI Neonatais quando poderiam estar em berçários intermediários. Um sistema integrado e hierarquizado de atenção à saúde deve contemplar serviços de medicina intensiva neonatal com graus diferenciados de complexidade para atender a recém-nascidos com diferentes níveis de gravidade (Viguri \& Dominique, 1998).

\section{Pertinência de se Uttilizar Critérios de Seleção de Pacientes}

Diante de um contexto em que os recursos efetivamente disponíveis não são suficientes para atender a todos os recém-nascidos que necessitam de medicina intensiva neonatal, por que não se deveria estabelecer critérios de seleção para escolher quais recém-nascidos devem usufruir do tratamento intensivo neonatal? Os intensivistas não consideram moralmente correto estabelecer critérios de seleção e levantam três argumentos principais para sustentar essa posição.

O primeiro é de cunho religioso: não se tem o direito de escolher quem vive e quem morre, sendo esta escolha uma prerrogativa de Deus. Cada recém-nascido tem um destino, e escolhê-lo, neste caso, é uma forma de 'fazer o papel de Deus' (playing God). Já o segundo argumento apela para os interesses da família, ressaltando o significado do recém-nascido para os pais, que tinham expectativas em relação a ele. O terceiro argumento apóia-se na linguagem dos direitos: se um número cada vez maior de recém-nascidos pode sobreviver a partir da tecnologia médica avançada, não existe justificativa moral para o Estado não oferecê-la a todos os recém-nascidos que necessitam dela.

Para a maioria dos intensivistas, não é comum surgirem situações no cotidiano de seu trabalho em que uma escolha entre recém-nascidos tenha de ser feita. Duas estratégias básicas são utilizadas pelos profissionais para lidar com a escassez dos recursos: a primeira, acomodase a UTI Neonatal de forma a incorporar os recém-nascidos que necessitam de atendimento, empregando-se diferentes medidas, tais como a instalação 
de incubadoras adicionais ou a retirada do equipamento de um recémnascido que necessita menos para um que precise mais. A desvantagem dessa estratégia é que superlota a unidade, piorando a qualidade do atendimento, com aumento no risco de infecção hospitalar.

A segunda estratégia consiste em transferir o recém-nascido para outro serviço ou, preferencialmente, transferir a gestante para outro hospital com leito de UTI Neonatal disponível, garantindo uma vaga para o recém-nascido, caso necessite de atenção intensiva. Entretanto, embora raras, existem situações nas quais esses tipos de arranjo para contornar e resolver o problema não são possíveis, devendo-se, portanto, escolher qual o paciente será atendido.

\section{Critérios Adotados para Seleç̃o de Pacientes}

Para os intensivistas, nas situações-limite em que seja preciso selecionar os pacientes, o principal critério adotado deveria ser a probabilidade de sobrevivência do recém-nascido ou a sua viabilidade. No entanto, esse critério apenas poderia ser utilizado nos casos em que houvesse um diagnóstico confirmado da condição clínica, e os profissionais levantam uma limitação e um questionamento no tocante à utilização desse critério. A limitação é que existe razoável imprevisibilidade no resultado das intervenções médicas e muitas incertezas quando se avalia o prognóstico dos recém-nascidos ou suas chances de sobreviver. O questionamento é que todo recém-nascido tem o direito à chance de sobrevida, independentemente da magnitude dessa probabilidade.

A respeito da limitação no sentido de se utilizar o critério de viabilidade, de fato existem, em muitas situações, incertezas em relação à avaliação dos possíveis benefícios e riscos que acompanham a admissão na UTI Neonatal (Solsona, 1998). No entanto, os médicos certamente têm responsabilidade em estabelecer um diagnóstico e prognóstico o mais acurado possível, avaliando as alternativas de tratamento disponíveis. 
Como observa Harris (1996), aceitando-se que existam boas razões morais para estabelecer prioridade com base no prognóstico, tem-se o problema prático de produzir a informação necessária, sem a qual injustiças podem ocorrer e questões podem surgir no que diz respeito à legitimidade da escolha por esse critério.

De fato, dois tipos de erro podem acontecer, ambos assinalados pelos profissionais. O primeiro é "tratar ativamente uma criança, que subseqüentemente torna-se inviável ou severamente deficiente". O segundo é "recusar tratamento para uma criança aparentemente irrecuperável, que sobrevive e se sustenta aos mais severos danos por causa da inação terapêutica" (Raivio, 1991: 136).

Em relação ao questionamento - o direito do recém-nascido às probabilidades de sobrevivência -, Harris (1996) argumenta que se cada pessoa tem direito igual à atenção à saúde, deve ser dado igual peso às probabilidades de o recém-nascido beneficiar-se de um tratamento que qualquer um possa ter, seja qual for esta probabilidade. Para esse autor, "se aqueles com melhor chance são sempre preferidos, isto inevitavelmente criaria uma aristocracia dos felizardos" (Harris, 1996: 279). Nesse questionamento, Harris está atribuindo um considerável peso ao direito igual, que cada pessoa possui, às suas chances de sobrevida. No entanto, deve-se ponderar, na tomada de decisões médicas, não apenas os interesses do recém-nascido, mas também a carga que recai sobre a família e sobre a sociedade ao oferecer a ele um tratamento.

Além disso, é possível que essa crítica seja pertinente quando a diferença de probabilidade de recuperação entre os recém-nascidos for relativamente pequena, como no exemplo dado pelo próprio Harris (1996): entre um paciente com 40\% de chance e outro com 90\% de probabilidade. Contudo, poderia ser razoável escolher com base no prognóstico, quando, por exemplo, a escolha ocorre entre um recém-nascido com anencefalia ${ }^{2}$ uma síndrome incompatível com a vida - e outro com um peso ao nascer de 2.500 gramas que, embora necessite de cuidados intensivos, tem, digamos, 90\% de probabilidade de se recuperar sem seqüelas. 


\section{Justificativas MORAis PARA A LiMITAÇ̃̃o do Esforço Terapêutico}

Duas decisões distintas devem ser tomadas ao se recorrer à medicina intensiva neonatal: a relativa à admissão, ou não, na UTI, e a que diz respeito à continuidade, ou não, da atenção intensiva.

No tocante à admissão, é extremamente difícil ter uma clara visão sobre a relação malefício/benefício, estabelecendo um prognóstico confiável imediatamente após o nascimento e decidindo, por exemplo, se é preciso ressuscitar um recém-nascido extremamente prematuro ou grosseiramente mal formado. Neste momento, uma conduta poderia ser implementar "todas as medidas de atenção intensiva disponíveis para prolongar a vida" até que melhor avaliação possa ser feita (Versuys \& Leeuw, 1995: 15). Nesse sentido, os tratamentos iniciados nesse momento devem ser considerados provisórios e, portanto, passíveis de ser interrompidos.

Os intensivistas também utilizam a conduta citada. Para eles, o critério de chance de sobrevida só seria utilizado depois que o recém-nascido estivesse internado na UTI Neonatal, para avaliar se os profissionais devem ou não investir tudo o que estiver ao seu alcance para prolongar a vida do recém-nascido. Lembremos que, nas UTIs Neonatais examinadas, grande parte da demanda é constituída por recém-nascidos prematuros, muitos deles gerados por mães que não tiveram acesso ao pré-natal ou, se o tiveram, não foram adequadamente acompanhadas de modo a se obter informações necessárias para uma avaliação confiável das chances de sobrevida da criança.

Quanto à continuidade da assistência, parece não existir diferença moral intrínseca entre matar e deixar morrer ou entre recusar e retirar uma intervenção médica, ao se considerar a conduta eticamente adequada que se deve adotar frente aos recém-nascidos que nascem em processo de morrer, por serem portadores de síndromes incompatíveis com a vida, embora a família e/ou os profissionais da saúde possam avaliar como psicologicamente mais perturbador remover do que recusar tratamentos (Marsden, 1992; Perrett, 1996; Monzó, Campos \& Rubí, 1998; McHaffie 
et al., 1999). Da mesma maneira, parece ser percebido como mais inquietante agir do que omitir, talvez porque as pessoas não se sintam tão moralmente responsáveis por suas omissões quanto por suas ações (Pace, 1996).

A maioria dos intensivistas é mais reticente em aceitar a retirada de medidas assistenciais do que a não-instauração das mesmas, embora as duas condutas sejam questionadas. Para os profissionais, a retirada de uma medida terapêutica pode ser vista, pela família, como perda de direitos do recém-nascido. Por outro lado, os intensivistas avaliam que a maior ou menor dificuldade de recusar ou retirar uma medida terapêutica depende do tipo de intervenção e da gravidade do recém-nascido.

De qualquer modo, como observa Morton (1996), o que é moralmente relevante é avaliar o quanto as medidas assistenciais são ou não benéficas (ou maléficas) para o paciente. Essa também é a opinião dos intensivistas que ressaltam que o fundamental é ponderar os riscos e os benefícios das intervenções médicas.

Com base em McHaffie et al. (1999), é possível caracterizar três grupos de recém-nascidos, em relação aos quais o critério de chance de sobrevivência poderia ser aplicado. O primeiro é composto por aqueles portadores de condições clínicas que levam inevitavelmente ao óbito, apesar da intervenção médica (situação sem esperança). Nessa situação, encontram-se recém-nascidos que, literalmente, nascem em processo de morrer, por serem portadores de síndromes incompatíveis com a vida, como a anencefalia, ou extremamente prematuros - abaixo de 23 semanas e 400 gramas -, entre outras condições clínicas graves.

Já o segundo grupo é composto por recém-nascidos que podem viver, caso o tratamento seja oferecido, mas cuja qualidade de vida futura é possivelmente paupérrima ou questionável - situação sem perspectiva. Finalmente, o terceiro grupo inclui aqueles que podem sobreviver com qualidade de vida normal ou razoável se o tratamento for oferecido situação com perspectiva. Conforme o relato do conjunto dos intensivistas, as duas UTIs analisadas atenderiam, sobretudo, a recém-nascidos prematuros, pertencentes aos dois últimos grupos. 
Entre os intensivistas, duas abordagens são observadas em relação à dúvida se o profissional deve ou não investir tudo o que estiver ao seu alcance para prolongar a vida do recém-nascido. Na primeira, essa conduta deveria ser adotada em relação a todos os três grupos de recém-nascidos caracterizados anteriormente - situação sem esperança, situação sem perspectiva e situação com perspectiva. Já na segunda abordagem, apenas no caso do primeiro grupo não se deveria investir todos os recursos disponíveis para prolongar a vida.

Os defensores da primeira abordagem recorrem a vários argumentos para sustentá-la, quais sejam: 1) a decisão de quem vive e quem morre é de Deus, devendo o profissional investir o que estiver ao seu alcance para garantir o direito à vida; 2) existe o perigo de se ampliarem os casos em que não se investiria tudo o que estiver ao alcance do médico para estender a vida, incluindo recém-nascidos cada vez menos graves; 3) não existem critérios seguros de prognósticos e, portanto, apenas com a intervenção é possível saber se o recém-nascido vai se recuperar ou não; 4) o médico não pode retirar as chances de sobrevivência do recém-nascido, mesmo que seja muito pequena, porque o que importa é o valor em si, que cada um possui; 5) o recém-nascido tem um significado para os pais, independentemente de alcançar desenvolvimento normal ou não; 6) os profissionais aceitam melhor a morte quando esta ocorre após se investir tudo que esteve ao seu alcance.

Essa primeira posição está baseada no princípio da sacralidade da vida, segundo o qual a "vida humana é sagrada e não pode ser tirada sob quaisquer circunstâncias" (Sklansky, 2001: 6). Para os que adotam esse princípio, existiria o "dever absoluto de respeitar os processos teleológicos da ordem natural, e de não interferir nela" (Mori, 1994: 338). Esse princípio pode ser justificado tanto numa perspectiva religiosa, quando se considera a vida sagrada e a decisão sobre a vida e a morte da alçada divina argumento apresentado pelos defensores dessa primeira abordagem -, quanto numa perspectiva não-religiosa, quando se sustenta que se deve respeitar o finalismo intrínseco da vida - posição que pode ser defendida por um materialista naturalista. 
No entanto, o reconhecimento de um direito à vida do recém-nascido pode entrar em conflito com o princípio de beneficência, estendendo a vida da criança às custas de muito sofrimento para ela e para seus pais ou permitindo a sua sobrevivência com uma carga muito alta para ambos. Por sua vez, essa posição parece estar baseada na idéia de que 'onde existe vida, existe esperança', ou porque pode haver um erro de diagnóstico ou prognóstico, ou por causa da incerteza da evolução clínica dos recémnascidos ou porque, brevemente, um novo tratamento efetivo pode ser desenvolvido (Sklansky, 2001).

Finalmente, essa posição recorre também ao argumento da ladeira escorregadia. Conforme este, a aceitação de uma atitude permissiva pode aumentar a tolerância para com atos similares, mas inaceitáveis. Tal risco não parece existir quando os quadros clínicos são claramente identificados. Assim, não parece que exista o risco de uma limitação do esforço terapêutico em relação à anencefalia, em que parece razoável a limitação - se estender para outros casos em que tal decisão seria inaceitável - como, por exemplo, um recém-nascido moderadamente prematuro (acima de 1.000 gramas).

Os defensores da segunda abordagem, relativa apenas ao primeiro grupo de recém-nascidos - situação sem esperança -, alegam que não se deve investir tudo o que estiver ao alcance do profissional para prolongar a vida do recém-nascido. Na perspectiva desse grupo de entrevistados, quando a cura não pode ser realizada e os recém-nascidos estão em processo de morrer, os médicos devem aceitá-lo e oferecer o tratamento paliativo necessário para propiciar ao recém-nascido uma morte com menos dor e sofrimento possível.

Os argumentos utilizados por esse grupo de entrevistados são os que seguem: 1) prolongar a vida do paciente, nesses casos, causa mais maleficência do que beneficência; 2) a atitude prepotente que não admite os limites na capacidade da medicina de obter resultados satisfatórios também é uma forma de 'fazer o papel de Deus'; 3) não é suficiente salvar o recém-nascido, pois é preciso considerar também, em alguma medida, sua qualidade de vida futura, bem como as condições sociais, econômicas e culturais da família para lidar com uma criança deficiente. 
Essa segunda posição está baseada no princípio da qualidade de vida, segundo o qual a vida só tem valor se provida de determinadas qualidades. Por conseguinte, levar em consideração a qualidade de vida do recém-nascido significa estar preocupado com sua capacidade futura para a reciprocidade nas relações humanas e com os custos humanos para a criança e a família (Campbell \& McHaffie, 1995).

Assim, como sugerem Versluys e Leeuw (1995: 15), o prognóstico da criança deve ser avaliado em termos funcionais, considerando-se as seguintes questões: 1) "Que habilidade comunicativa a criança terá?"; 2) "A criança será capaz de levar uma vida independente?"; 3) "A criança estará continuadamente dependente de serviços médicos?"; 4) "A criança sofrerá mentalmente ou psiquicamente?"; 5) "Qual é a expectativa de vida?".

Nessa perspectiva, a morte não deve ser vista como um inimigo a ser combatido sempre, transformando-se o direito à vida em um direito de impedir a morte a todo custo, além de um limite que poderia ser considerado razoável. Essa postura refletiria, por um lado, "um ideal médico de imortalidade corporal", no qual a "falha em vencer a morte pode ser experimentado como uma falha pessoal" (Marsden, 1992: 414). Por outro lado, a exposição diária a tecnologias sofisticadas e o alto nível de confiança que estas geram nos pacientes e profissionais da saúde podem impedir estes últimos de considerar todas as opções disponíveis, entre as quais a morte do paciente quando o tratamento é considerado fútil.

Na avaliação de Pierucci, Kirby e Leuthner (2001: 657), os médicos "ainda praticam o modelo tradicional de atenção paliativa, tratando as pessoas que não podem ser curadas somente no fim de seu adoecimento", o que é oposto a um modelo mais recente, que consiste em envolver aqueles que estão em risco de morrer ou, no caso da medicina intensiva neonatal, os pais do recém-nascido, incrementando esse envolvimento quando as terapias curativas não funcionarem. Esse processo pode ter reflexo na atenção ao paciente, aumentando a incidência de recusas em instituir ou dar continuidade a medidas médicas agressivas, tais como: ressuscitação cardiorrespiratória, medicação cardíaca e ventilação mecânica, entre outras. 
Por sua vez, deve-se considerar o interesse da família em partilhar com o filho um certo tempo, estendendo um pouco o período de vida do recém-nascido, de modo que ela possa elaborar minimamente os sentimentos envolvidos nessas situações, tais como a decepção e a culpa da mãe por ter gerado um recém-nascido inviável - ou seja, para que ela se prepare, em última instância, para o trabalho do luto. Nessa perspectiva, reconhece-se que, em alguns casos, a intervenção pode não gerar benefícios médicos, mas os benefícios pessoais, religiosos e sociais podem ser suficientemente significativos, justificando o prolongamento, mesmo que pequeno, da vida do recém-nascido (McTurk, 1996).

\section{PARTICIPAÇÃO DA FAMÍlia nas Decisões Médicas}

Como ressalta Marsden (1992: 410), "o direito de uma pessoa competente de aceitar ou recusar atenção médica, incluindo tratamentos que sustentam a vida" está baseado no princípio da autonomia, que estabelece que "as pessoas são livres para fazer as escolhas que determinam o curso de suas vidas".

Entretanto, no caso da medicina intensiva neonatal, os recémnascidos não são competentes para tomar essas decisões. Nesse caso, o padrão moral a ser seguido é decidir a respeito do melhor interesse do paciente; isto é, o tratamento deve ser provido nos casos em que sua vida poderá conter mais benefícios do que cargas (Marsden, 1992; Norup, 1998). Como observa Sklansky (2001: 6), nessa área da medicina, "o princípio de autonomia, naturalmente, tem uma posição secundária em relação ao imperativo moral da beneficência e não maleficência".

Norup (1998: 203), no entanto, comenta que "de acordo com a ampla 'visão da qualidade de vida', a decisão sobre o tratamento não deve estar baseada, exclusivamente, sobre uma avaliação dos interesses da criança, mas pode também envolver considerações dos interesses" da família, bem como do uso de recursos médicos e sociais.

Mas, independentemente do padrão moral a ser seguido na tomada de decisões médicas, como deve ser a participação da família nessas 
decisões? Entre os intensivistas, predomina uma posição contrária à participação da família na tomada de decisões médicas. Dois argumentos são utilizados para justificar tal posição: 1) os pais, por serem leigos, não compreenderiam, de modo adequado, as informações relativas à condição clínica do recém-nascido, para participar conscientemente na tomada de decisão; 2) os pais não têm condições emocionais para participar na tomada de decisão, em virtude do grande sofrimento a que estão sendo submetidos.

Contudo, os profissionais salientam a importância de informar adequadamente a família, utilizando-se linguagem acessível. Ressaltam, para o caso de gestações de alto risco, a preparação dos pais quanto à viabilidade, ou não, do recém-nascido e a possibilidade, ou não, de internação na UTI neonatal, e enfatizam o aconselhamento genético do casal em relação às gestações futuras.

Em relação ao primeiro argumento contrário à participação da família na tomada de decisões médicas - os pais não compreendem as informações -, é preciso destacar que os médicos têm uma responsabilidade para assegurar uma boa comunicação com os pais, de forma que as informações concernentes à atenção ao recém-nascido sejam convenientemente partilhadas, tal como as decisões conjuntamente adotadas. Assim, a equipe profissional deve apresentar aos pais, de modo imparcial, toda informação disponível e relevante para a tomada de decisão, incluindo os argumentos favoráveis ou contrários aos vários cursos de ação alternativos, de modo que estes possam tomar suas próprias decisões (Maldonado \& Álvarez, 1998).

De qualquer forma, as decisões relativas à aceitação ou recusa de tecnologias que sustentam a vida envolvem interpretações de médicos e familiares em relação aos possíveis efeitos das intervenções na UTI Neonatal. Os médicos "devem identificar as alternativas disponíveis e os riscos e benefícios de cada uma delas", mas "não podem determinar o valor que outorgam as diferentes pessoas às diversas opções" (Marín, 1998: 93). Assim, o médico pode julgar a probabilidade de sucesso de uma intervenção de modo a considerar que não vale a pena implementá-la, enquanto os familiares podem ver a mesma probabilidade de outra forma. 
Da mesma maneira, médicos e familiares podem pesar diferentemente os benefícios e as cargas que o tratamento oferece.

Quanto ao segundo argumento, contrário à participação da família na tomada de decisões médicas, vários autores têm salientado o estado vulnerável dos pais, abalados por não terem gerado o bebê normal e saudável que imaginaram (Raivio, 1991; Morton, 1996; Hammermam et al., 1997).

Dessa forma, esses autores consideram que a família deve ser adequadamente informada, mas sua participação na tomada de decisão precisa ser cuidadosamente ponderada. Por um lado, porque pode ser penoso para os pais viverem o resto de suas vidas com o peso de terem decidido sobre a vida e morte de seus filhos. Por outro lado, porque o estado emocional dos pais pode obscurecer-lhes a avaliação sobre o que seria o melhor interesse do recém-nascido. Com efeito, a opinião da família está freqüentemente baseada em falsas esperanças no que concerne à recuperação do paciente e à descoberta de algum novo remédio capaz de curá-lo, bem como em avaliações otimistas sobre a capacidade de a tecnologia contribuir para a sua recuperação.

Sob qualquer ponto de vista, como observam McHaffie et al. (2001: 105), os profissionais devem, nesse momento, guiar os pais de modo a lhes "facilitar um processo de sofrimento saudável", com um mínimo de remorso pelo resultado trágico da gravidez.

Por sua vez, vários autores têm sustentado uma abordagem segundo a qual, embora médicos e pais devam ser parceiros na tomada de decisão quanto à recusa ou retirada de tratamentos médicos para os recém-nascidos, essas decisões estariam, primariamente, sob a responsabilidade dos doutores (Campbell \& McHaffie, 1995; Morton, 1996; Rubi \& Navarro, 1998).

Se, por um lado, os profissionais reconhecem que os médicos são os agentes legalmente autorizados para tomar decisões médicas, por outro, é enfatizado, sobretudo pelos enfermeiros, a importância de uma abordagem multidisciplinar, acreditando-se que a combinação das contribuições de todos os membros da equipe poderia proporcionar melhor assistência ao recém-nascido. Ressalta-se o papel do enfermeiro no cuidado diário com o recém-nascido e a relação que estabelece com a família, contribuindo, com 
o médico, no processo de esclarecimento sobre as condições clínicas do recém-nascido, assim como na preparação dos pais para enfrentar esse difícil momento.

De fato, alguns autores têm enfatizado o papel das enfermeiras, as quais, em razão do contato cotidiano com o recém-nascido e os pais, podem contribuir significativamente na tomada de decisões médicas: em relação ao recém-nascido, fornecendo importantes avaliações sobre a sua condição clínica e, no que diz respeito aos pais, compreendendo melhor seus sentimentos e desejos (Raivio, 1991; Campbell \& McHaffie, 1995).

Para Szawarski e Tulczynski (1988), tem sido cada vez mais reconhecido, pela prática médica ocidental, o papel do profissional de enfermagem como legítimo parceiro para a discussão sobre a saúde e a vida do recém-nascido. Nesse sentido, Melia (1996: 138) enfatiza o trabalho em equipe e a promoção de uma "ética de atenção à saúde como um empreendimento multidisciplinar" e não como uma arena na qual uma ética médica e outra de enfermagem se contrapõem. Para essa autora, a "noção de uma ética de atenção à saúde" focalizada sobre o paciente e a sociedade, mais do que nas profissões, poderia ser um caminho promissor para superar essa fratura.

\section{CONCLUSÃO}

Entre as duas abordagens defendidas pelos intensivistas - a da qualidade e a da sacralidade de vida -, a primeira tem a vantagem de ponderar, na tomada de decisões médicas, não apenas os supostos interesses do recém-nascido, mas também a carga que pode eventualmente recair sobre a família e sobre a sociedade, ao oferecer tratamento a um recém-nascido, permitindo, assim, que os legítimos interesses de todos possam ser mais adequadamente considerados. Esta diferença entre as duas abordagens é particularmente importante se o objetivo for a justa distribuição dos recursos públicos de atenção à saúde e, em particular, o acesso às tecnologias médicas, em que está em questão a forma considerada justa de distribuir os benefícios e as cargas entre os cidadãos de uma sociedade. 
Nessa perspectiva, se forem levados em conta os três grupos de recém-nascidos caracterizados aqui - os que nascem em processo de morrer, os que sobrevivem com qualidade de vida pobre ou questionável e os que sobrevivem com qualidade de vida normal ou razoável - é aceitável pensar que é no segundo grupo que residem as maiores dificuldades. É muito mais difícil uma avaliação da sociedade a respeito do investimento neste grupo.

Por isso, pensamos que se deve investir em pesquisas que possam contribuir para o desenvolvimento de critérios prognósticos mais acurados para os pacientes criticamente doentes; pesquisas capazes de predizer com razoável certeza suas chances de sobrevida ou sua provável qualidade de vida. De fato, não acreditamos que as dificuldades encontradas nessa área de pesquisa possam ser tão maiores do que aquelas que existem em outras áreas da pesquisa biomédica.

NOtAS

1 Foram entrevistados dez médicos e dez enfermeiros de duas UTIs Neonatais localizadas no Estado do Rio de Janeiro (uma na região metropolitana e outra no interior), sendo ambas referência para a atenção neonatal e cadastradas no Sistema Único de Saúde (SUS) - uma pública e outra filantrópica.

2 A anencefalia é uma anomalia do desenvolvimento embrionário em que se constata a não-formação total ou parcial do encéfalo (Rey, 2003).

\section{REFERÊNCIAS BIBLIOGRÁFICAS}

CAMPBELL, A. G. M. \& MCHAFFIE, H. E. Prolonging life and allowing death: infants. Journal of Medical Ethics, 21: 339-344, 1995.

GOODMAN, D. C. et al. Are neonatal intensive care resource located according to need? Regional variation in neonatologists, bed, and low birth weight newborns. Pediatric, 108(2): 426-431, 2001. 
HAMMERMAN, C. et al. Decision-making in the critically ill neonate: cultural background v. individual life experiences. Journal of Medical Ethics, 23: 164-169, 1997.

HARRIS, J. What is the good of health care? Bioethics, 10(4): 269-291, 1996.

MALDONADO, A. L. \& ÁlVAREZ, S. Ética y familiares de pacientes ingresados en una unidad de cuidados intensivos. In: GÓMEZ, R. J. A. \& ABIZANDA, C. R.(Orgs.) Bioética y Medicina Intensiva: dilemas éticos en el paciente crítico. Barcelona: EDIKA MED/SEMICYUC, 1998.

MARÍN, J. Reanimación cardiopulmonar y órdenes de no reanimacíon. In: GÓMEZ, R. J. A. \& ABIZANDA, C. R. (Orgs.) Bioética y Medicina Intensiva: dilemas éticos en el paciente crítico. Barcelona: EDIKA MED/SEMICYUC, 1998.

MARSDEN, C. An ethical assessment of intensive care. International Journal of Technology Assessment in Health Care, 8(3): 408-418, 1992.

MCCULlOUGH, L. B. A transcultural preventive ethics approach to critical care medicine: restoring the critical physician's power and authority. Journal of Medicine and Philosophy, 23(6): 828-842, 1998.

MCHAFFIE, H. E. et al. Withholding/withdrawing treatment from neonates: legislation and official guidelines across Europe. Journal of Medical Ethics, 25: 440-446, 1999.

MCHAFFIE, H. E. et al. Deciding for imperilled newborns: medical authority or parental autonomy? Journal of Medical Ethics, 27: 104-109, 2001.

MCTURK, L. Rational resource allocation: ethical perspective. In: PACE N. A. \& MCLEAN, S. A. M. (Orgs.) Ethics and the Law in Intensive Care. New York: Oxford University Press, 1996.

MELIA, K. M. The nursing perspective. In: PACE N. A. \& MCLEAN, S. A. M. Ethics and the Law in Intensive Care. New York: Oxford University Press, 1996.

MONZÓ, J. L. S; CAMPOS, R. A. \& RUBÍ, J. A. G. Limitación del esfuerzo terapéutico en la prática clínica. In: GÓMEZ, R. J. A. \& ABIZANDA, C. R. (Orgs.) Bioética y Medicina Intensiva: dilemas éticos en el paciente crítico. Barcelona: EDIKA MED/SEMICYUC, 1998. 
MORI, M. A bioética: sua natureza e história. Humanidades, 9(4): 333$341,1994$.

MORTON, N. S. Pediatric issues. In: PACE, N. A. \& MCLEAN, S. A. M. (Orgs.) Ethics and the Law in Intensive Care. New York: Oxford University Press, 1996.

NORUP, M. Limits of neonatal treatment: a survey of attitudes in the Danish population. Journal of Medical Ethics, 24: 200-206, 1998.

PACE, N. Withholding and withdrawing medical treatment. In: PACE, N. A. \& MCLEAN, S. A. M. (Orgs.) Ethics and the Law in Intensive Care. New York: Oxford University Press, 1996.

PERRETT, R. W. Killing, letting die and the bare difference argument. Bioethics, 10(2): 131-139, 1996.

PIERUCCI R. L.; KIRBY, R. S. \& LEUTHNER, S. R. End-of-life for neonates and infants: the experience and effects of palliative care consultation service. Pediatrics, 108(3): 653-660, 2001.

RAIVIO, K. O. Ethical problems in neonatal intensive care. International Journal of Technology Assessment in Health Care, 7(supl. 1): 136-138, 1991.

REY, L. Dicionário de Termos Técnicos de Medicina e Saúde. Rio de Janeiro: Guanabara Koogan, 2003.

RIBEIRO, C. D. M. "Cultura dos limites", justiça sanitária e alocação dos recursos: argumentações racionais acerca dos conflitos morais em medicina intensiva neonatal, do ponto de vista dos profissionais intensivistas, 2003. Tese de Doutorado, Rio de Janeiro: Escola Nacional de Saúde Pública/Fundação Oswaldo Cruz.

RUBI, J. A. G. \& NAVARRO, A. R. Limitación del esfuerzo terapêutico. Fundamentos éticos. In: GÓMEZ, R. J. A. \& ABIZANDA, C. R. (Orgs.) Bioética y Medicina Intensiva: dilemas éticos en el paciente crítico. Barcelona: EDIKA MED/SEMICYUC, 1998.

SKLANSKY, M. Neonatal euthanasia: moral considerations and criminal liability. Journal of Medical Ethics, 27: 5-11, 2001. 
SOCIETY OF CRITICAL CARE MEDICINE (SCCM). Definitions, 1999. Disponível em: http://www.sccm.org/accm/guidelines/guide_body_definitions.httm. Acesso em: 1 jun. 2001.

SOLSONA J. F. Critérios de selección: el triage em la UCI. In: GÓMEZ, R. J. A. \& ABIZANDA, C. R. (Orgs.) Bioética y Medicina Intensiva: dilemas éticos en el paciente crítico. Barcelona: EDIKA MED/SEMICYUC, 1998.

SVENNINGSEN, N. W. Neonatal intensive care: when and where is it justified? International Journal of Technology Assessment in Health Care, 8(3): 457-468, 1992.

SZAWARSKI, Z. \& TULCZYNSKI, A. Treatment of defective newborns: a survey of paediatricans in Poland. Journal of Medical Ethics, 14: 11-17, 1988.

VERSLUYS, Z. \& LEEUW, R. A Dutch report on the ethics of neonatal care. Journal of Medical Ethics, 21: 14-16, 1995.

VIGURI, N. P. R. \& DOMINIQUE, N. P. Consideraciones sobre microasignación y macroasignación de los recursos sanitarios. In: GÓMEZ, R. J. A. \& ABIZANDA, C. R. (Orgs.) Bioética y Medicina Intensiva: dilemas éticos en el paciente crítico. Barcelona: EDIKA MED/SEMICYUC, 1998. 


\section{Macacos sem Mãe, Pesquisas sem Ética: LIÇÕES DOS ESTUDOS DE SEPARAÇ̃̃O MATERNO- INFANTIL E SEUS DESAFIOS À BIOÉTICA 11 \\ Rita Leal Paixão}

\section{INTRODUCÃO}

Um trecho encontrado em um trabalho científico de 1971 chama a atenção daqueles que hoje se preocupam com questões éticas: “Experimentação... com pacientes humanos é seriamente dificultada pela falta de controle experimental e pelas fortes restrições éticas. Esses problemas não existem para o pesquisador que trabalha com macacos" (Suomi apud Blum, 1994: 90).

Trata-se de uma afirmação encontrada na tese de doutorado de Steve Suomi (1971), realizada sob a orientação de Harry Harlow, conhecido psicólogo experimental, cujas principais investigações abordaram a questão da separação materno-infantil em macacos Rhesus. A afirmação expressa o pensamento vigente naquele momento em relação à Ciência e à ética na experimentação. Se, por um lado, demonstra uma preocupação com a ética na pesquisa em relação aos seres humanos; por outro, exclui qualquer tipo de preocupação dessa natureza em relação aos primatas não-humanos e, certamente, o mesmo pensamento se estenderia, naquela época, a qualquer outro animal não-humano.

Em relação ao ato científico, a afirmação revela a incessante busca dos pesquisadores pelo 'controle experimental' e a expectativa vigente de que o modelo animal sempre permitiria que se purificasse cada vez mais o 'fenômeno', a fim de que fosse possível testemunhá-lo. Foi de acordo com essa perspectiva de utilizar macacos sem qualquer preocupação ética - 
como se fossem meros tubos de ensaio - e perseguindo o reconhecimento da psicologia experimental como uma ciência natural, capaz de ser submetida ao rigor do controle experimental, que Harry Harlow tornou-se polêmico. Por vezes reconhecido como um pesquisador inteligente e influente, também como um homem cruel e desumano, que deixou um triste legado à Ciência, Harlow, sua obra e seus seguidores tornaram-se alvos de intensos debates científicos e éticos a partir dos anos de 1970.

De fato, a década de 1970 traria significativas reflexões e mudanças no campo da ética. O nascimento da Bioética foi um marco nesse sentido. O entendimento do contexto em que ele ocorre permite concordar que se iniciava uma "complexificação do campo da moralidade" (Schramm, 1997: 102). Pois, como se sabe, uma série de acontecimentos, ainda nos anos de 1960, prepararam o terreno para que a Bioética se transformasse em algo mais do que um neologismo a partir dos anos de 1970, quando Potter a anunciou pela primeira vez. Vários episódios e fatos que contribuíram para o nascimento da Bioética podem ser relembrados a partir de diversos relatos sobre a sua história. Aqui não se pretende discorrer sobre tais fatos, mas deve-se lembrar que 'as restrições éticas' citadas na afirmação anterior por Suomi em relação às pesquisas com seres humanos já expressavam as preocupações surgidas, em grande parte, devido às denúncias de abusos em pesquisas envolvendo seres humanos, ocorridas no fim dos anos de 1960 (Beecher, 1966).

Naquele momento, começava um controle social - que se tornaria cada vez mais intenso - sobre as atividades que ocorriam nos laboratórios e em nome da Ciência. É por isso que se pretende refletir aqui sobre o que aconteceu no momento em que os resultados dos estudos de separação materno-infantil em macacos saíram dos laboratórios para a sociedade e começaram, de uma forma não esperada por seus idealizadores, a exercer sua influência nesse debate ético. Paradoxalmente, a Ciência, que trancou, isolou e separou os macacos de suas mães, abria as janelas para mostrar à sociedade, científica ou não, que esses animais não-humanos eram algo mais do que meros objetos de laboratório. Com isso, as portas dos laboratórios foram abertas pelos movimentos sociais para mostrar que não há mais um 
espaço da atividade humana imune aos questionamentos éticos, inclusive atividades científicas que envolvem animais não-humanos. Portanto, problemas de natureza ética existem para pesquisadores que trabalham com animais não-humanos, ao contrário do que possa já ter sido afirmado.

\section{As Pesquisas de Harlow, a Busca Científica e suas Repercussões}

Harry F. Harlow (1905-1981), psicólogo americano, estudou e obteve seu doutorado na Universidade de Stanford e desenvolveu suas pesquisas em primatas não-humanos na Universidade de Wisconsin, a partir das quais ganhou notável reconhecimento científico nos anos 1960. Tornouse o primeiro psicólogo eleito para a Academia Nacional de Ciências de seu país, além de ter alcançado outras posições relevantes no meio acadêmico e alguns prêmios científicos importantes, tal como a medalha de ouro da Associação Americana de Psicologia, em 1973.

É possível crer que o fato de Harlow ter conseguido uma posição de destaque entre seus pares tenha contribuído para que maior atenção fosse dada ao seu trabalho também por parte da sociedade em geral. Além de serem publicados em periódicos científicos, seus procedimentos experimentais e conclusões chegavam aos outros meios de comunicação, como a imprensa e a televisão, além de serem freqüentemente divulgados pelo próprio Harlow através de palestras e entrevistas e, com isso, foram atraindo, aos poucos, diversos tipos de interesses (Blum, 1994).

O interesse de Harlow no início de sua carreira, nos anos de 1940, era basicamente a questão do processo de aprendizado em macacos. Através do que chamou de 'aparelho do aprendizado', Harlow testou a capacidade de macacos Rhesus em resolver problemas. Nesse aparelho, o macaco era apresentado a dois objetos diferentes, situação na qual deveria aprender a escolher o 'objeto certo' (definido pelo experimentador e que acarretaria uma recompensa alimentar para o macaco). Assim, o macaco era apresentado a vários pares de objetos, sendo recompensado cada vez que escolhia o objeto certo. 
Harlow demonstrou que, nesse tipo de experimento, os macacos rapidamente 'aprenderam a aprender', de tal forma que quando o macaco escolhia o objeto certo, na primeira tentativa, ele continuava a escolher sempre o certo (o teste constituía-se de seis repetições). Se ele escolhia o objeto errado, logo na próxima tentativa ele trocava de objeto e, portanto, acertava e passava a só escolher o certo nas tentativas restantes. Com isso, Harlow levantou a hipótese de que os macacos mostravam-se capazes de aplicar uma regra geral, um 'princípio' (que pode ser explicado como 'se a primeira escolha está certa, fique com ela; se não está, troque e não volte a ela') que era, então, aplicado para resolver novos desafios, isto é, cada vez que um par de objetos diferentes era apresentado (Dethier \& Stellar, 1988).

Um outro tipo de teste desenvolvido por Harlow foi o do 'aprendizado pelo princípio do objeto diferente' (Dethier \& Stellar, 1988). Nesse caso, o macaco deveria escolher o objeto diferente entre três apresentados a ele. Também nesse tipo de teste, os macacos desempenharam bem a tarefa, a ponto de passarem, depois de alguns ensaios, a acertar na primeira tentativa, quando apresentados a um novo trio de objetos. Ou seja, os macacos eram capazes de levar o princípio geral de uma situação para a outra - concluiu Harlow (1949). No entanto, essa conclusão gerou uma grande discussão no meio científico e tornou-se alvo de diversas críticas.

Uma das principais críticas referia-se ao fato de que Harlow não tinha 'controlado' o desenvolvimento do animal, visto que trabalhou com animais já adultos capturados na natureza (Orlans et al., 1998). Dessa forma, segundo alguns cientistas, não havia garantia de que as respostas observadas já não fizessem parte do repertório comportamental do animal no seu hábitat natural. Na verdade, essa questão precisa ser vista não apenas como uma crítica ao método experimental utilizado por Harlow e sua equipe, pois o que estava em jogo era também uma proteção ao tipo de pensamento dominante associado à psicologia naquela época, ao qual a teoria de Harlow ameaçava. Para que se torne possível entender o tipo de ameaça que as descobertas de Harlow significavam é preciso que sejam revistos alguns conceitos vigentes naquela época. 
Desde 1920, a psicologia norte-americana encontrava-se sob a influência da escola behaviorista, o que se estendeu para vários outros países até por volta da década de 1970. Metodologicamente, o behaviorismo considerava como única fonte legítima de conhecimento os experimentos controlados e como única área pertinente aos estudos da psicologia as respostas comportamentais aos estímulos externos (Elzanowski, 1998). Dessa forma, não se devia falar em estados mentais e nem sobre a questão da consciência, os quais eram ignorados, de acordo com esse tipo de abordagem.

O que permitiu o estudo do comportamento no domínio da Ciência foi exatamente a noção de reflexo, descrita inicialmente por Descartes em 1622, que se referia a uma ação automática, um 'mecanismo natural' (Descartes, 1971). O reflexo - essa ação automática - era sediado no corpo de seres humanos e dos animais, enquanto que apenas os seres humanos apresentavam também um outro princípio não-mecânico, racional, sediado na 'alma'.

Essa oposição entre corpo e alma e mecanismos reflexos e racionais era o ponto de partida para estudos psicológicos que investigavam apenas os reflexos. Isso explica por que considerar estados mentais nos animais, assim como consciência e sentimentos, era não só inapropriado como também não-científico (Gluck, 1998). As explicações mecanicistas dominavam e ratificavam a visão cartesiana do animal-máquina, correspondente a um simples autômato. Falar em sofrimento ou qualquer emoção nos animais não-humanos não tinha significado algum para os pesquisadores behavioristas da época, assim como para os cientistas em geral. O grande estudioso do comportamento animal, Konrad Lorenz (1993: 103), se expressou dessa forma em relação ao behaviorismo:

Quando, por outro lado, behavioristas colocam pombos experimentais dentro de uma caixa opaca que evita a percepção de qualquer informação, exceto aquela de quando e quão freqüentemente o pombo aperta uma barra, eu não posso evitar a idéia de que eles não querem ver as outras atividades executadas pelo animal, porque têm medo de que o que vissem pudesse diminuir sua crença em seu próprio monismo explicativo. 
Por isso, quando levantou a hipótese de que um macaco poderia apresentar uma habilidade cognitiva complexa capaz de 'solucionar problemas', Harlow rapidamente atraiu críticas. Isso abalava a crença no modelo explicativo vigente e contrariava a visão que se poderia ter de um animal de acordo com a escola behaviorista. Considerando que os chamados processos cognitivos, tais como pensamento, raciocínio e intenção, não são diretamente observáveis, tornava-se mais fácil para os behavioristas ignorá-los.

Apenas nos anos de 1960, quando teve início a chamada 'revolução cognitiva', foi-se tornando evidente que desconsiderar a ocorrência de processos cognitivos era uma distorção no estudo da natureza do comportamento animal. Quando alguns estudos começaram a demonstrar indiretamente a existência desses processos nos animais, a opção estava entre ignorá-los, rejeitá-los ou aceitá-los. Por isso é que os primeiros estudos nessa linha de abordagem de 'solução de problemas' - antes de Harlow - foram praticamente ignorados devido ao grande ceticismo com que foram recebidos.

Tais estudos foram desenvolvidos por Wolfgang Köhler no início dos anos de 1920, nos quais ele observou que chimpanzés eram capazes de empilhar um monte de caixotes a fim de subir neles e alcançar um cacho de bananas que, de outra forma, não poderia ser alcançado. Os chimpanzés também se mostraram capazes de unir duas varetas para, então, formar uma vara longa para puxar o alimento, que não podia ser alcançado com uma só vareta (Dethier \& Stellar, 1988). No entanto, naquele momento, não se admitiu que os chimpanzés pudessem solucionar problemas (no caso, desenvolver um meio de alcançar o alimento) e nem que aquela era uma forma de 'ferramenta' confeccionada por primatas não-humanos. Afinal, a capacidade de confeccionar ferramentas era uma entre as várias características utilizadas para diferenciar primatas humanos e não-humanos.

Somente com o trabalho de Jane Goodall, já nos anos de 1960, a capacidade de os chimpanzés confeccionarem ferramentas não pôde mais ser ignorada ou rejeitada. Como ela mesma relata: 
E quando descrevi como um chimpanzé, Mike, resolveu espontaneamente um novo problema utilizando uma ferramenta (ele partiu um pedaço de pau para derrubar no chão uma banana, estando nervoso demais para tirá-la ele próprio de minhas mãos), não creio que tenha havido um franzir de cenhos na comunidade científica. Posso garantir que não fui maldosamente atacada, como acontecera com Köhler e Yerkes, por sugerir que os humanos não eram os únicos seres capazes de raciocínio e percepção. (Goodall, 1991: 24)

O mais interessante é que Jane Goodall observou os chimpanzés no seu próprio hábitat, na natureza, sem restringir as alternativas oferecidas aos animais, tal como acontecia nos laboratórios de estudos comportamentais, promovendo, dessa forma, também uma grande mudança nos métodos de investigação comportamental.

Porém, Harlow, nos anos de 1940, quando viu o 'franzir de cenhos na comunidade científica', resolveu buscar um maior 'controle experimental' como resposta às críticas sofridas. Para isso, a estratégia seria separar os macacos Rhesus de suas mães logo ou pouco após o nascimento, de tal forma que seu desenvolvimento fosse observado e controlado de acordo com o delineamento experimental. Cabe ressaltar que, em decorrência de seus estudos, o próprio Harlow montou as instalações do centro de primatas da Universidade de Wisconsin, onde eram mantidos os primatas e onde teria início a criação propriamente dita.

Em relação ao contexto científico da época, é também importante destacar que os primatas eram trazidos de outros países, principalmente da Índia, e estima-se que, por exemplo, nos anos de 1950, os Estados Unidos tenham importado cerca de 200 mil macacos Rhesus por ano (Blum, 1994).

Isso explica a grande disponibilidade desses animais naquele momento, o que, certamente, representava um fator de estímulo para o pesquisador que quisesse trabalhar com macacos. Uma outra fonte de estímulo que levava ao crescimento do uso de primatas em pesquisas ocorria devido, principalmente, a alguns fatores, tais como: o sucesso advindo de alguns estudos, o crescimento da indústria aérea, que fez diminuir as mortes desses animais durante o transporte (quando 
comparada com o transporte desses animais em navios) e a descoberta de drogas sedativas, que permitiram uma melhor e mais segura manipulação desses animais.

Um famoso estudo em macacos, em 1940, foi a descoberta do fator Rh no sangue ('Rh' vindo de 'Rhesus', devido à descoberta ter ocorrido graças a estudos em macacos Rhesus), feita por Landsteiner e Alexander Wieblood (Blum, 1994). No início dos anos de 1950, destacaram-se os estudos em busca de uma vacina contra a pólio. Os cientistas descobriram que o vírus da pólio crescia em culturas de células de macacos. Com isso, aumentou a demanda por macacos Rhesus, que passaram a representar um 'instrumento' importante de pesquisa. A vacina contra a pólio chegou em 1958 graças aos trabalhos de Albert Sabin, fazendo com que aumentasse ainda mais a demanda por primatas nas pesquisas biomédicas (Blum, 1994). E como o 'modelo' animal foi tornando-se mais conhecido e manipulável, aumentavam também as pesquisas comportamentais. Foi exatamente aí, no fim da década de 1950, que os estudos de Harlow tomariam um novo direcionamento e se voltariam para as pesquisas comportamentais sobre a separação materno-infantil.

Embora a causa da separação dos filhotes de macacos Rhesus de suas mães nos protocolos experimentais de Harlow tenha-se dado inicialmente com vistas à obtenção de uma padronização dos animais quanto à idade e ao tipo de vida, para melhor observar as habilidades relacionadas ao aprendizado, as observações de Harlow o levariam a novas questões, tais como: 1) que fatores contribuem para o vínculo usualmente observado entre mãe e filho?; 2) quais as conseqüências dessa separação?; 3) quais as conseqüências do isolamento social? Ele se propôs, até mesmo, a investigar 'a natureza do amor'.

Em 1958, Harlow publicou um de seus trabalhos mais famosos, considerado um clássico na história da psicologia: A Natureza do Amor. Naquele momento, algumas explicações tentavam dar conta do vínculo observado entre mãe e filho, de uma forma geral. A postura, usualmente defendida por psicólogos e sociólogos, atribuía tal vínculo às motivações primárias, incluindo fome, sede e dor, enquanto que os outros motivos, 
como amor ou afeto, eram derivados ou motivações secundárias. Isto é, o vínculo estabelecido entre o filho e a figura materna estava diretamente associado à capacidade da mãe em reduzir a fome, a sede e a dor principalmente, enquanto que outros fatores, tais como o toque ou o ato de abraçar, eram secundários, segundo o entendimento da perspectiva predominante (Harlow, 1958).

Harlow demonstrou que esse entendimento - a teoria com base na nutrição para explicar o apego do filho à mãe - estava equivocado, a partir de seus experimentos, nos quais ele conseguiu isolar o 'fator alimentação' do 'fator contato materno'. Em uma das variações dos experimentos iniciais de Harlow, os filhotes de macacos Rhesus foram separados de suas mães entre 6 e 12 horas após o nascimento e colocados isolados, cada qual em uma gaiola com 'duas mães substitutas', idealizadas pelo próprio Harlow. Uma mãe substituta, de corpo cilíndrico, era feita de arame e a outra, de pelúcia, sendo que ambas tinham calor adequado, provido por uma lâmpada, e apenas a mãe metálica apresentava um 'mamilo artificial' que garantia a alimentação do filhote. O surpreendente observado nos resultados desse experimento foi o fato de que o filhote preferiu o aconchego e conforto da 'mãe de pelúcia' ao alimento vindo da 'mãe metálica' (Harlow, 1958). Porém, mesmo com esses resultados, permanecia uma dúvida: teria realmente se estabelecido um vínculo, um 'apego' à mãe substituta ou, simplesmente, um maior conforto explicava o fato de os filhotes ficarem a maior parte do tempo com a substituta mais parecida com a mãe verdadeira, independentemente do fator alimento?

Para testar isso, Harlow iniciou outra série de experimentos, nos quais os filhotes eram expostos a situações que provocavam medo quando juntos com a mãe substituta de pelúcia, a fim de que se pudesse observar se realmente existia 'apego' à mãe substituta ou se isso acabaria com o 'conforto' e os filhotes se afastariam. Os resultados mostraram que, com medo, os filhotes mais se agarravam à mãe e, ainda, os que estavam com a mãe substituta reagiam mais rapidamente, reduzindo suas respostas de medo e até mesmo indo explorar o estímulo causador do medo inicial, ao contrário daqueles que tinham sido mantidos completamente isolados. 
Com a continuidade dos experimentos, Harlow observou também que macacos criados com as chamadas 'mães substitutas' eram tímidos na resposta a estranhos ou a situações estranhas, que não brincavam normalmente com seus companheiros e não se acasalavam bem quando se tornavam adultos, comparados com os macacos jovens criados pelas mães verdadeiras. Se a mãe substituta era feita de arame, essas deficiências em comportamento social eram ainda mais profundas e os animais apresentavam um repertório comportamental completamente inadequado. Mas se a mãe substituta era feita de pelúcia e enchimento macio, os sintomas eram menos acentuados. E, ainda, o filhote se desenvolvia melhor se a mãe substituta balançava ou se movimentava ao invés de permanecer imóvel (Harlow, 1959).

Os achados de Harlow fizeram com que a questão do aprendizado propriamente fosse esquecida por ele e sua equipe e os conduzissem a fazer diversos experimentos que, a partir da separação dos filhotes de suas mães, visavam a verificar os efeitos do isolamento social e a produzir psicopatologias, passando do estudo da 'afeição' para criar um 'modelo de depressão'.

Foi dessa forma que a década de 1960 testemunhou os polêmicos experimentos cruéis. Os efeitos da privação social foram investigados de várias formas (Harlow \& Harlow, 1962). Em alguns experimentos, os filhotes, com algumas horas de vida, foram mantidos isolados por meses em uma câmara de aço inoxidável, sem nenhum tipo de contato com outros animais ou seres humanos. Em outras variações experimentais, os filhotes eram entregues às chamadas 'mães-monstros' (substitutas artificiais ou fêmeas criadas totalmente isoladas, contidas à força e inseminadas e, portanto, com comportamento anômalo), que sacudiam, batiam, mordiam e até esmagavam os filhotes. As descrições encontradas nesses trabalhos científicos quase sempre apresentam, de forma detalhada, um quadro de desespero, expresso em choros, gritos, busca da mãe e automutilação por parte dos filhotes.

Outro aspecto relatado nesses trabalhos era a intenção de uma aproximação ao que acontecia em crianças com alterações comportamentais 
e institucionalizadas, ou seja, a proposta de estudar seres humanos a partir do modelo animal (Harlow, Gluck \& Suomi, 1972). Porém, diante desses relatos, relevantes questões vieram à tona (Pearce, 2004): se os filhotes de macacos não sentissem afeição por suas mães, medo, solidão e desespero como as crianças, então para que estudá-los? E se eram capazes de sentir afeto, de sofrer e se desesperar tal como crianças, como justificar moralmente que pudessem ser submetidos a tais procedimentos? É esse tipo de questionamento que vai permear a discussão na década de 1970 e nas décadas seguintes e, ainda que Harlow tenha se aposentado em 1970, seus seguidores continuaram com os estudos de separação maternoinfantil, alguns até nos dias de hoje.

\section{As Críticas, os Movimentos Socials e O Status Moral dos Primatas Não-Humanos}

Os estudos de separação materno-infantil estão hoje entre as linhas de pesquisa mais combatidas pelos grupos de proteção animal. É possível encontrar na Internet sites de organizações que denunciam as instituições onde ocorrem estudos que envolvem separação materno-infantil de primatas, quase sempre relembrando os estudos de Harlow e enumerando uma série de críticas. Em geral, seguidores da linha de pesquisa de Harlow, tais como Levine, Rosenblum e Sackett, recebem cartas ameaçadoras, alguns tiveram laboratórios atacados e sofrem críticas públicas (Blum, 1994).

É fato que a chamada questão animal entrou em debate no cenário social internacional e, especialmente, que todo tipo de experimentação animal tornou-se foco de diversas críticas. Vários aspectos, principalmente na década de 1970, contribuíram para que a questão animal viesse à tona e, embora não se pretenda historicizar aqui os fatos pertinentes a essa questão, é relevante delinear as particularidades desses estudos sobre separação materno-infantil nesse processo. Eles atraíram grande atenção da sociedade em geral e também da comunidade científica, tornaram-se polêmicos, até mesmo odiados, e acabaram contribuindo para a própria causa dos movimentos de liberação animal, como será visto adiante. 
Uma primeira lição das pesquisas de Harlow foi o fato de que foram feitas importantes revelações sobre os próprios macacos. Numa época em que os animais ainda eram vistos como seres irracionais, máquinas incapazes de emoções, tanto os estudos sobre o aprendizado quanto as descrições detalhadas das atitudes dos filhotes sem mãe - que necessitavam de afeto - contribuíram para que essa visão do animal-máquina começasse a ser questionada. Como era intrigante um animal preferir carinho ao alimento! Desde Aristóteles e sua negação da razão aos animais, passando por Descartes e sua afirmação do animal-máquina, a Ciência apenas ratificava essa visão através do behaviorismo e permitia que uma nítida barreira se mantivesse entre seres humanos e não-humanos.

Diversos achados, subseqüentes à década de 1960, começaram a demolir essa barreira e mostraram que alguns primatas não-humanos podem construir ferramentas, fazer contas, se reconhecer no espelho, entre tantos outros aspectos até então categorizados como 'comportamentos humanos' e, até mesmo, apresentar uma linguagem e ter uma cultura própria (Hauser, 2001). A mudança da visão sobre 'quem é esse animal' afirmava a necessidade de discussão de outra questão 'qual o status moral desse animal?' - e, conseqüentemente, ampliava a esfera de abrangência moral.

Um outro aspecto a ser destacado nos experimentos de Harlow é o uso do conceito de 'modelo animal', isto é, o interesse de Harlow e sua equipe era supostamente o conhecimento do que aconteceria com seres humanos se estivessem naquelas condições de isolamento e, para conhecer o comportamento social humano, utilizavam o modelo animal. A inadequação do uso desse 'modelo animal' foi apontada por vários críticos dos estudos de Harlow (Reines, 1989; Stephens, 1986; Liss, 2002).

Em 1986, Martin Stephens, biólogo e vice-presidente da Humane Society of the United States (HSUS), desenvolveu a análise crítica mais detalhada que se tem sobre os estudos de separação materno-infantil; seus argumentos estavam embasados nos seguintes aspectos: as pesquisas eram bastante cruéis para os animais, os resultados produzidos não foram úteis para ajudar os seres humanos e as variações propostas nos 
delineamentos experimentais faziam com que os experimentos não tivessem fim, embora não contribuíssem para considerações clínicas em seres humanos.

Peter Singer (2002) também criticou o trabalho de Harlow, levando em conta, além da questão moral, o fato de que diversas descrições das investigações apontavam sempre para a necessidade de mais estudos, os quais nunca eram conclusivos. De fato, questões sobre a importância da interação materno-infantil já tinham sido abordadas em estudos com seres humanos, especialmente por Spitz e Wolf (1946) e Bowlby (1960). Antes mesmo de Spitz e Wolf, Bakwin (1942) já havia chamado a atenção para as altas taxas de mortalidade de bebês nos orfanatos no fim do século XIX e início do século XX. Já John Bowlby era um dos proeminentes psicanalistas da época de Harlow e defendia a importância inata do contato e do ato de abraçar no desenvolvimento do apego materno-infantil. Em um de seus estudos, ao observar crianças que foram separadas de suas mães, Bowlby elaborou um modelo de resposta que teria uma fase inicial chamada de 'protesto', a qual se caracterizava por agitação, seguida de uma 'depressão', na qual predominavam a tristeza e a retração social e, finalmente, por um certo 'afastamento' em relação à mãe, quando ocorria uma nova aproximação.

Um estudo de Seay, Hansen e Harlow (1962), que visava a observar o mesmo efeito em primatas, obteve dados diferentes em relação à terceira fase, na qual, em vez de afastamento, mãe e filhote tinham maior aproximação, ao contrário do que acontecia nos seres humanos. Posteriormente, o fato de os macacos serem animais arborícolas foi lembrado para revelar a importância de o filhote se agarrar mais à mãe e para, mais uma vez, criticar o uso do 'modelo animal' (Reines, 1989).

As questões de os estudos não serem originais e de vários dados contradizerem pesquisas em seres humanos aparecem nas críticas aos trabalhos de Harlow. Outro fato apontado pelos críticos é que, embora as pesquisas tenham fornecido entendimento sobre privação materna nos laboratórios, o valor desse entendimento é questionável quando aplicado a seres humanos e não-humanos que vivem fora do ambiente laboratorial altamente artificial. 
Colotla (1979) também demonstrou que o fenômeno da depressão produzida em laboratório e os casos encontrados na prática clínica forneceram dados contraditórios. Embora Harlow tenha influenciado significativamente a aceitação da psicologia experimental, nas últimas décadas observa-se uma crescente crítica referente à insuficiência da atual abordagem experimental do comportamento (Cunha, 1989). Realmente, além da abordagem moral, nos anos de 1970, o método científico da experimentação animal começou a receber também críticas que chamaram a atenção para o fato de os animais não serem bons 'modelos' para o estudo de seres humanos e, ainda, é acusado de desviar a atenção de outros métodos de pesquisa que seriam mais eficazes (Reusch, 1978). Essas críticas aumentaram ainda mais nos anos seguintes (Sharpe, 1988; Croce, 1999, Pound et al., 2004) e era de se esperar que, no campo da psicologia, tais críticas se tornassem ainda mais proeminentes (Shapiro, 1998).

Um outro aspecto que pode ser destacado no trabalho de Harlow diz respeito às descrições feitas em seus artigos e suas repercussões. Em vários de seus relatos, pôde-se observar termos geralmente evitados no discurso científico e que evocam fortes imagens emocionais, tais como: 'poço de desespero', para referir-se à câmara de aço onde os filhotes eram mantidos isolados; 'rack de estupro', para identificar a técnica desenvolvida por sua equipe com o intuito de emprenhar fêmeas que não aceitavam naturalmente o acasalamento; 'mães-monstro', para designar as mães que maltratavam os filhotes, mesmo que fossem artificiais, entre outros.

Os detalhes descritos com comentários considerados irônicos também se tornaram uma marca pessoal do cientista, como quando descreveu a preferência dos filhotes pela mãe substituta de pelúcia e concluiu: "nós podemos ter certeza de que nem todo amor é cego" (Harlow, 1958: 680). Além disso, em uma famosa entrevista de 1974, quando questionado sobre sua interação com os animais, ele declarou com forte convicção que desprezava gatos, odiava cães e, portanto, não poderia gostar de macacos também (Blum, 1994). Segundo alguns, o que ele gostava realmente era de chamar a atenção para si próprio, e esses aspectos, certamente, contribuíram ainda mais para chocar a opinião pública, 
especialmente à medida que aumentava a preocupação com o bem-estar animal nos laboratórios.

Assim, essa visão de 'macacos torturados' pela ciência foi tornandose pública ao longo dos anos de 1970, de tal forma que, em 1981, o Instituto de Pesquisa Comportamental, em Silver Spring, Maryland, foi invadido pela polícia devido a denúncias de que crueldades estavam sendo cometidas contra primatas não-humanos. Esse fato - o caso dos macacos de Silver Spring, como ficou conhecido - tornou-se marcante, pois foi a primeira vez na história da Ciência que a força policial entrou num laboratório de pesquisa científica. Tratava-se de investigações que envolviam traumas cranianos, que eram realizados em primatas não-humanos por Edward Taub, o qual, em conseqüência da denúncia de maus-tratos aos animais feita por Alex Pacheco, um dos fundadores do People for the Ethical Treatment of Animals (Peta) -, foi julgado e condenado inicialmente por maus-tratos a seis animais, embora em última instância o processo tenha sido revertido (Rudacille, 2000).

Esse caso teve um grande impacto no debate sobre a experimentação animal. Afinal, a comunidade científica percebeu pela primeira vez que, independentemente da 'validade científica', a questão do bem-estar animal precisava ser seriamente considerada. Em contrapartida, o movimento em prol dos animais percebeu que havia uma crescente possibilidade de interferir nas políticas de controle no uso de animais. Uma das conseqüências diretas desse episódio foi a inclusão de um item específico voltado para a obrigação de garantir 'bem-estar psicológico em primatas não-humanos' submetidos à experimentação na lei americana de bem-estar animal (Animal Welfare Act), na época de sua revisão em 1985.

Vale lembrar que essa mesma lei surgiu nos Estados Unidos em 1966, também em decorrência de um episódio que envolveu o uso de um cão por proprietários de um laboratório de pesquisa. Esse fato mobilizou instituições não-governamentais e culminou com a confecção da lei, a fim de minimizar os conflitos que emergiam no campo da experimentação animal. No entanto, foi preciso esperar até a década de 1980 para que a lei começasse a surtir efeitos. Foi nos anos de 1980 
que os comitês institucionais de ética animal começaram a atuar de fato nos Estados Unidos.

Um aspecto que traz à memória os estudos de Harlow é quando observamos as recomendações das atuais diretrizes (National Institute of Mental Health, 2002) sobre procedimentos que ocasionem o isolamento do animal. Nesses casos, os pesquisadores devem levar em conta que o isolamento do animal, especialmente de um primata, por si só, independentemente de qualquer outro procedimento a ser realizado, já faz com que o procedimento experimental seja considerado um 'experimento de severidade substancial'.

\section{CONSIDERAções Finais: UM DESAFIO PARA A BIOÉTICA}

Os aspectos mencionados, tais como a mudança da visão sobre o animal, especialmente sobre primatas; as críticas científicas à ampla utilização do 'modelo animal'; o papel ativo exercido pela sociedade, particularmente através de organizações não-governamentais em prol dos animais, assim como uma mudança na própria comunidade científica em reconhecer a relevância do bem-estar animal, fizeram com que o debate moral sobre a forma como interagimos com os animais ocupe um lugar na agenda da Bioética. Ao mesmo tempo que esses fatos demonstram alguns dos conflitos, contradições e incertezas que vêm ocorrendo em torno da experimentação animal, desde a época de Harlow até os dias de hoje, demonstram, também, que já não é possível negar totalmente um status moral, pelo menos a alguns animais (seres sencientes).

Provavelmente, nos anos de 1980, Suomi já não afirmaria que não existiriam problemas éticos em trabalhar-se com macacos e, certamente, hoje, afirmaria que trabalhar com primatas não-humanos é seriamente dificultado pelas fortes restrições éticas. De fato, é possível falar-se num aumento do controle das pesquisas em animais nos últimos anos, em diversos países, o que se dá principalmente através de legislações específicas, avaliações por comissões de éticas e avaliações na hora da 
publicação de trabalhos em revistas científicas, pelo menos naquelas que exigem, para a aceitação do trabalho, uma revisão ética por algum Comitê de Ética de Pesquisa.

Tais restrições têm-se pautado, principalmente, pela busca do bemestar animal e por uma avaliação ética do tipo conseqüencialista, avaliandose custos e benefícios em cada caso. No entanto, longe de chegar-se a um consenso, discute-se cada vez mais como essas 'avaliações éticas' vêm sendo feitas. Esses conflitos sobre o papel das 'avaliações éticas' foram recentemente expostos na revista Science através de um interessante estudo de Plous e Herzog (2001), no qual fica evidente que ainda não há habilidade das comissões em realizarem julgamentos confiáveis sobre qual pesquisa deve ser aprovada e qual não deve ser aprovada. A discussão é de fato bem mais ampla, porque envolve, além dos reformistas - os quais trabalham dentro da perspectiva atual de utilização animal para melhorar a qualidade de vida dos animais -, os abolicionistas, que visam a eliminar todas as formas de utilização dos animais que envolvem dor e sofrimento. Talvez, a partir do debate sobre o trabalho de Harlow, mais alguma lição possa ser útil sobre isso também.

Um fato curioso foi a interpretação de Harlow quando se deparou com dados contraditórios dos estudos realizados em seres humanos e daqueles feitos em animais: ele simplesmente afirmou que a teoria baseada em seres humanos era falsa. Para Harlow, os dados observados em macacos eram os 'verdadeiros', os quais deveriam ser aplicados aos humanos (Harlow, Gluck \& Suomi, 1972). Um fato que entraria para os anais da História Científica (Reines, 1989). Afinal, não era a ciência experimental, comprovada nos laboratórios, que deveria explicar a realidade fora dos laboratórios?

Os tempos mudaram e, sem dúvida, a própria Ciência permitiu ao ser humano conhecer melhor toda a realidade à sua volta. No entanto, há nesse debate várias tentativas de conhecer mais e mais detalhes sobre os animais, muitas vezes no intuito de continuar fazendo listas de diferenças entre seres humanos e não-humanos, por mais que a continuidade entre as espécies não possa mais ser negada; quando se observam procedimentos 
para 'medir a dor', 'medir o sofrimento', por mais que já estejam provadas as experiências emocionais de alguns animais; quando se observa toda uma avaliação de custos nos animais para serem pesados numa balança utilitarista em que do outro lado estão benefícios para os seres humanos, por mais que se tenha clareza de que serão dois pesos e duas medidas; quando se observa tudo isso, de fato, surge a pergunta se o homem não está, mais uma vez, tentando achar a resposta para os conflitos da realidade nos laboratórios. Pois, como disse Turner (1980: 140), "nós temos pensado muito pouco sobre as formas e as origens das nossas mais simples atitudes". Eis aí um desafio para a Bioética.

\section{REFERÊNCIAS BIBLIOGRÁFICAS}

BAKWIN, H. Loneliness in infants. American Journal of Diseases in Children, 63: 30-40, 1942 .

BEECHER, H. K. Ethical and clinical research. New England Journal of Medicine, 274: 1.354-1.360, 1966.

BLUM, D. The Monkey Wars. New York: Oxford University Press, 1994.

BOWLBY, J. Grief and mourning in infancy and early childhood. Pschoanalitic Studies of Child, 15: 9-52, 1960.

COLOTLA, V. A. Experimental depression in animals. In: KEEHN, J. D. (Ed.) Psychopathology in Animals - research and clinical implications. New York: Academic Press, 1979.

CROCE, P. Vivisection or Science? An investigation into testing drugs and safeguarding health. New York: Zed Books, 1999.

CUNHA, W. H. A. Insuficiência dos atuais princípios explicativos do comportamento - Proposição de princípios novos. In: ADES, C. (Org.) Etologia de Animais e de Homens. São Paulo: Edicon/Editora da Universidade de São Paulo, 1989.

DESCARTES, R. De homine. In: HERSTEIN, R. J. \& BORING, E. G. (Orgs.) Textos Básicos de História da Psicologia. São Paulo: Edusp, 1971. 
DETHiER, V. G. \& STELlAR, E. Comportamento Animal. São Paulo: Edgar Blücher, 1988.

ELZANOWSKI, A. Behaviorism. In: BEKOFF, M. \& MEANEY, C. A. (Eds.) Encyclopedia of Animal Rights and Animal Welfare. Connecticut: Greenwood Press, 1998.

GLUCK, J. P. Animal cognition. In: BEKOFF, M. \& MEANEY, C. A. (Eds.) Encyclopedia of Animal Rights and Animal Welfare. Connecticut: Greenwood Press, 1998.

GOODALL, J. Uma Janela para a Vida: 30 anos com os chimpanzés da Tanzânia. Rio de Janeiro: Jorge Zahar, 1991.

HARLOW, H. F. The formation of learning sets. Psychological Review, 56: 51-65, 1949 .

HARLOW, H. F. The nature of love. American Psychologist, 13: 573-685, 1958. Disponível em: http://psychclassics.yorku.ca/Harlow/love.htm. Acesso em: 21 de nov. 2004

HARLOW, H. F. Affectional responses in the infant monkey. Science, 130: 421-432, 1959.

HARLOW, H. F. \& HARLOW, M. K. Social deprivation in monkeys. Scientific American, 207: 137-147, 1962.

HARLOW, H. F.; GLUCK, J. P. \& SUOMI, S. J. Generalization of behavioral data between nonhuman and human animals. American Psychology, aug.: 709-716, 1972 .

HAUSER, M. D. Wild Minds. What animals really think. New York: Owl Books, 2001.

LISS, C. Forcibly breaking the maternal blond. Animal Welfare Institute Quartely on the Web, 31(2): Spring 2002. Disponível em: http:// www.awionline.org/pubs/Quarterly/Spring02/maternalbond.htm. Acesso em: 21 nov. 2004

LORENZ, K. Os Fundamentos da Etologia. São Paulo: Unesp, 1993.

NATIONAL INSTITUTE OF MENTAL HEALTH (NIMH). Methods and Welfare Considerations in Behavioral Eesearch With Animals. Report of a National 
Institutes of Health Workshop. NIH Publication n. 02-5083. Washington, DC: U.S. Government Printing Office, 2002.

ORLANS, F. B. et al. The Human Use of Animals. Case studies in ethical choice. New York: Oxford University Press, 1998.

PEARCE, D. Proving the obvious: Harry Harlow. Disponível em: http:// www.petersingerlinks.com/proving.htm. Acesso em: 21 nov. 2004.

PLOUS, S. \& HERZOG, H. Reliability of protocol reviews for animal research. Science, 293: 608-609, 2001.

POUND, P. et al. Where is the evidence that animal research benefits humans? British Medical Journal, 328: 514-517, 2004.

REINES, B. P. A critique of animal psychology research at the University of California at Berkeley. Perspectives on Animal Research on the Web, vol. I, 1989. Disponível em: http://www.curedisease.com/resources.html. Acesso em: 21 nov. 2004.

REUSCH, H. Slaughter of the Innocent. New York: Bantam Books, 1978.

RUDACILLE, D. The Scalpel and the Butterfly: the conflict between animal research and animal protection. Berkeley: University of California Press, 2000.

SCHRAMM, F. R. Niilismo tecnocientífico, holismo moral e 'Bioética global' de V. R. Potter. História, Ciências, Saúde - Manguinhos, IV: 95-115, 1997.

SEAY, B.; HANSEN, E. \& HARLOW, H. F. Mother-infants separation in monkeys. Journal Child Psychology and Psychiatry, 79: 334-340, 1962.

SHAPIRO, K. J. Animal Models of Human Psychology: critique of science, ethics and politics. New York: Hogrefe \& Huber Pub, 1998.

SHARPE, R. The Cruel Deception: the use of animals in medical research. Northamptonshire: Thorsons Publishing Group, 1988.

SINGER, P. Animal Liberation. New York: Ecco-Harper Collins Publishers, 2002.

SPITZ, R. A. \& WOLF, K. M. Anaclitic depression. Psychoanalitic Studies of Child, 2: 313-342, 1946.

STEPHENS, M. Maternal Deprivation Experiments in Psychology: a critique of animal models. Boston: NEAVS, 1986. 
SUOMI, S. Experimental Production of Depressive Behavior in Young Monkeys, 1971. Tese de Doutorado, Madison: University of Wisconsin.

TURNER, J. Reckoning With the Beast: animals, pain, and humanity in the victorian mind. Baltimore: Johns Hopkins University, 1980. 


\section{Bioética e Pediatria}

\section{2}

Arnaldo Pineschi de Azeredo Coutinho

\section{INTRODUCÃO}

O avanço dos estudos e da conceituação sobre a autonomia fez com que aumentasse também a dúvida de como se conduzir em situações de conflito, nas quais a análise dos limites da autonomia seja obrigatória. A dificuldade surge em decorrência de não ser possível ainda, apesar das definições formais existentes, dar o assunto como encerrado, com o risco de ser aquém da complexidade do estudo que o tema requisita. É salutar que se deixe portas abertas à discussão, mas também que a discussão seja sempre feita em bases fundamentadas ou teorias que apresentem algum indicativo de racionalidade e aplicabilidade ética.

O termo 'autonomia' origina-se da palavra grega autonomia, composta pelo adjetivo pronominal autós ('o mesmo', 'o próprio', 'por si mesmo') e nómos ('costume', 'convenção', 'lei'), significando a competência de 'dar-se as próprias leis'. No sentido ético, importa a discussão sobre a capacidade para entender a autonomia dentro do binômio liberdade/normas. Essa capacidade de entendimento pode ser fruto de várias interpretações sobre quem é o indivíduo que obedece a leis feitas por ele próprio (Rousseau), ou que obedece às normas de sua própria razão (Iluminismo), ou que escolhe seus valores, faz seus projetos e toma suas decisões (Kant). Ou, ainda, entender quem é aquele indivíduo que preserva a liberdade individual, mas valoriza a utilidade do ato (utilitarismo) (Segre, Silva \& Schramm, 1998). 
Na prática da Bioética, essas diferenças trazem conseqüências importantes porque:

segundo a concepção kantiana, infringir o princípio de autonomia consiste em violar substancialmente a própria pessoa, ao passo que para a concepção utilitarista infringir o princípio de autonomia pode ser justificado tendo em conta outros objetivos desejáveis e, portanto, úteis à própria pessoa. (Segre, Silva \& Schramm, 1998: 20)

Isso faz com que, de acordo com o sistema ético escolhido, haja uma coexistência entre os princípios de autonomia, beneficência e nãomaleficência, fato este que relativiza cada princípio tomado isoladamente $e$, muitas vezes, reconfigura as hierarquias de valores estabelecidas de antemão, de acordo com as características de cada situação. Isso implica procurar sempre entender e dirimir as dúvidas e resolver os conflitos dentro de uma análise contextual, na qual se valorize o grau de discernimento do agente moral, a ponderação entre riscos e benefícios do ato para a pessoa, entendendo que a autonomia não deva ser exercida quando, desse exercício, resultar dano à própria ou a outras pessoas.

Ainda dentro da discussão sobre autonomia, há que se dedicar espaço para a relação médico-paciente, principalmente na questão da criança e do adolescente, no que tange ao consentimento esclarecido a respeito do dispositivo legal naquelas situações em que já existe um avançado grau de discernimento e de tomada de decisão confrontando com o permitido em função da idade. Isso está explícito no Código Civil que diz o seguinte: "são absolutamente incapazes de exercer pessoalmente os atos da vida civil: I - os menores de dezesseis anos" (Manole, 2004: 200).

Na pediatria, é importante que se veja esse ser do ponto de vista holístico, considerando seu desenvolvimento globalmente, sua capacidade de entender e de tomar decisões e não somente a sua idade cronológica. A simples aplicação do dispositivo legal pode induzir à anulação de uma vontade, já legítima, por ser decorrente de uma capacidade de discernimento já presente na criança e no adolescente, na maioria das vezes. 
O exercício da autonomia leva ao reconhecimento do direito à proteção e ao respeito aos valores que qualquer indivíduo merece. No entanto, essa autonomia não deve ser absoluta, principalmente naquelas situações da prática médica em que se constate um iminente risco de vida, em que se deve sempre procurar preservar o bem maior, sob risco de ser caracterizada uma postura de omissão por parte do médico. E, no caso da criança e do adolescente, a preocupação aumenta na medida em que tal desrespeito ao exercício de suas autonomias possa levar a abusos, gerando violência, tanto física quanto psíquica, e, ainda, tanto institucional quanto doméstica. Em síntese, a autonomia deve ser entendida como o principal referencial em qualquer relacionamento, no qual o reconhecimento dos seus limites e o respeito a eles vão balizar as condutas. Fica, então, mais claro que a prática desse princípio propiciará a profilaxia da violência e dos abusos contra a criança e o adolescente.

\section{A Situacẽo da lnfânCla}

Existe, no Brasil, uma preocupação com a infância e a adolescência manifesta em toda a legislação pertinente, bem como uma cultura cada vez mais desenvolvida de valorização e proteção dessa faixa etária como sinal de respeito pela sua autonomia e seus direitos. O reconhecimento da criança e do adolescente como seres com capacidade, ainda que relativa, de agir por conta própria e com direito à proteção de seus interesses legítimos faz com que sejam criados organismos e leis que se prestam a esse fim.

Há, no país, uma razoável rede de serviços de saúde, educação e assistência social, como também marcos legais fundamentais como o Estatuto da Criança e do Adolescente (ECA), as Leis Orgânicas da Saúde e a Lei de Diretrizes e Bases da Educação (LDB). Além disso, há o Censo da Educação Infantil, o Programa de Saúde da Família (PSF), o Programa Nacional de Imunizações (PNI) e outros programas voltados para essa faixa etária. A sociedade organizada também dispõe de entidades médicas, como a Sociedade Brasileira de Pediatria e suas ramificações estaduais, que já têm em suas composições comitês e departamentos de defesa dos direitos 
da criança e do adolescente e que fazem um trabalho conjunto com as esferas governamentais nessa área. A Sociedade Brasileira de Pediatria conta em sua organização, ainda, com um Departamento de Bioética, que também se ocupa, pelas próprias características, com assuntos relacionados a essa faixa etária. Também de fundamental importância são os conselhos tutelares como guardiões da integridade das crianças e dos adolescentes.

Por si mesmos, esses marcos legais representam um avanço que implica garantir o direito igual de todas as crianças a um nome e à nacionalidade, à alimentação, a bons cuidados de saúde, à educação básica, à justiça e à igualdade em sua condição de seres humanos. Mas, de maneira geral, a qualidade do atendimento das crianças pode e deve ser melhorada de modo a assegurar, desde a gestação, seus desenvolvimentos físico, social, psicológico, cognitivo e emocional.

Situações especiais de vulnerabilidade, nas quais se incluem o trabalho infantil, os maus-tratos, o abuso, a violência e a privação do direito ao convívio familiar, têm um grande impacto na vida da criança e em como ela aprende a criar modelos para suas atitudes sociais. Isso já demonstra a importância da prevenção da violência contra a criança e o adolescente porque, além de sua proteção contextual, física e emocional, há o cuidado na formação desse ser para que, no futuro, não venha a se tornar também um agressor, como um reflexo do que sofreu em sua infância e adolescência.

Há que existir todo um desprendimento e uma disposição da sociedade para a educação, procurando criar famílias esclarecidas e tratadas com eqüidade em suas necessidades. A inserção da pessoa na sociedade a partir de uma família estruturada vai, a princípio, resultar em maior respeito à pessoa e, conseqüentemente, diminuir as agressões e os desrespeitos à autonomia das crianças e dos adolescentes.

Grandes desafios ainda se impõem, em que pesem os avanços já conquistados, para a garantia dos direitos fundamentais desses seres. $\mathrm{O}$ maior desses desafios é, com certeza, a pobreza, que perpetua a exclusão social através de um círculo vicioso, causando evasão familiar e escolar e deixando crianças e adolescentes expostos à exploração, discriminação e 
violência. A iniqüidade no tratamento das famílias na faixa de pobreza é, com certeza, um dos grandes fatores etiológicos da violência social e da exploração de menores.

Segundo o Instituto Brasileiro de Geografia e Estatística (IBGE), em estudo realizado em 1998, 30,5\% das famílias brasileiras com crianças entre 0 e 6 anos de idade vivem com renda per capita igual ou inferior a meio salário mínimo (Unicef, 2001). Assim como bem-estar significa mais do que possuir riqueza, pobreza tem um significado maior do que simplesmente ter uma renda para cobrir as necessidades mínimas de uma família. Sinais de que as necessidades básicas, como saúde frágil, baixa escolaridade, discriminação e marginalização, não estão sendo atendidas também são indicadores de pobreza. Por isso, ela está intimamente ligada ao acesso inadequado a serviços sociais básicos, como escolas, postos de saúde e saneamento adequado (Unicef, 2001).

\section{Os Limites da Autonomia e os PRincíplos da Bió́tica}

O pluralismo ético e a diversidade de valores morais existentes hoje na sociedade fazem com que fique difícil a busca de soluções harmoniosas e generalizadas sobre assuntos ligados à saúde, à vida e à morte. A necessidade de uma teoria acessível e prática para a solução de conflitos de caráter ético fez surgir o principialismo como forma de estudo, análise e proposição de solução dos problemas no campo biomédico. Surge, então, o modelo dos quatro princípios de beneficência, não-maleficência, autonomia e justiça (Kipper \& Clotet, 1998). Sinteticamente:

- Beneficência - refere-se à obrigação ética de fazer o bem. Procura maximizar benefícios e minimizar danos ou prejuízos. É um corolário da atenção à saúde, pois fazer o bem é algo implícito à própria ação de viver e conviver. É próprio da espécie humana e parte integrante das informações transmitidas pelas gerações no processo de criação e desenvolvimento da espécie. 
- Não-maleficência - preconiza não fazer o mal e, junto com o princípio anterior, proíbe infligir danos deliberadamente. Porém, vão surgir situações em que será necessário causar um dano, só que visando a um bem maior. Por exemplo, a amputação de um pé de um diabético é um dano: mutila o paciente, é deliberado, já que é fruto de uma decisão médica para a situação que se apresenta e, além disso, proporcionará uma qualidade de vida provavelmente menor. No entanto, leva à manutenção da vida, que é o bem maior. Prevalece, nesse exemplo, a beneficência, mesmo havendo um dano causado. Contudo, é importante que fique claro que só se encontra justificativa ética para se causar um dano se o principal beneficiado for o próprio paciente. E outra lição que se tira desse exemplo é que essa amputação deve ser o desfecho de um processo em que o paciente dê seu consentimento depois de seu total esclarecimento, no qual, após pesar o risco-benefício, deve fazer valer sua autonomia e, em conjunto com o médico, optar pelo que for melhor para o seu caso.

- Autonomia - pressupõe que a pessoa é livre para fazer suas escolhas desde que suficientemente esclarecida. Deve ter liberdade de pensamento e estar livre de coações para escolher entre alternativas apresentadas. Se não há chance de escolha ou alternativa apresentada, não há o exercício da autonomia. Existem situações especiais e muito conflitantes nas quais um ser, entendido como pessoa, não tem condições de expressar-se e de escolher, como, por exemplo, as crianças, os deficientes mentais e os fetos, entre outros. Mas são pessoas e, como tais, devem ter seus direitos preservados e proteção à sua integridade. Há que se ter mecanismos de controle para que os 'responsáveis legais' não exerçam sua autonomia de maneira deletéria sobre seus protegidos ou tão-somente em benefício de seus próprios interesses.

- Justiça - refere-se ao ato de dar a cada pessoa o que lhe é devido, tratando cada um de acordo com o que é moralmente certo ou adequado numa situação específica. É a eqüidade na distribuição e no acesso. Por esse princípio não se pode negar à pessoa o acesso ao que de melhor se dispuser para a satisfação de suas necessidades. A justiça como eqüidade e como forma de distribuição de bens e de arbitrar as oportunidades de acesso a 
esses bens pode ser vista de duas maneiras: 1) o tratamento igual para os iguais, onde todos os necessitados seriam igualados e os bens distribuídos como uma porção igual para cada um (todos recebem igual); 2) o tratamento desigual para os desiguais, onde haveria uma discriminação positiva dando prioridade aos que têm menos condições sociais ou de capital, onde cada um receberia de acordo com a sua necessidade (os que têm menos recebem mais).

\section{Quem Deve Decidir: O CONTEXTO NORMATIVO}

Quem deve decidir? O médico que sabe mais? Ou o paciente, dono de seu corpo? Na prática médica atual, cada vez torna-se mais difícil a resposta a essa questão. Conquanto o médico seja detentor do conhecimento do que seja mais efetivo e conveniente na escolha da conduta propedêutica e terapêutica a tomar, cada vez mais se propala a valorização da opinião do paciente e seu consentimento após ser plenamente esclarecido sobre seu caso e a conduta mais apropriada. Por conduta propedêutica entende-se todos os meios utilizados para chegar a um diagnóstico (exames laboratoriais, de imagem, biópsias, cirurgias e outros) e, por conduta terapêutica, todos os procedimentos indicados para o tratamento do caso em questão.

O conceito de medicina compartilhada vem em função da dificuldade de tomar uma decisão em determinadas circunstâncias, devendo essas decisões ser fruto de diálogo entre pessoas com valores morais diferentes, procurando resolver os conflitos de maneira racional e pactuada, numa análise contextual da situação (Kipper et al., 2002). Todos devem utilizar argumentação ética e racional para a defesa de seus pontos de vista.

A postura do médico - seja isoladamente ou com seu paciente, seja em equipe multiprofissional de assistência - deve contemplar e respeitar a pluralidade ético-cultural da sociedade atual. Ao médico estaria afeita à beneficência, e ao paciente, a autonomia. Porém, há que se lembrar sempre que existe a autonomia do médico como profissional na condução do caso, procurando sempre o melhor para seu paciente. 
A face deontológica do exercício profissional do médico em relação à autonomia do paciente está contemplada no Código de Ética Médica (1998) no Capítulo IV - "Direitos Humanos", no Capítulo V - "Relação com Pacientes e Familiares" e no Capítulo IX - "Segredo Médico", quando preconiza o que é vedado ao médico:

Art. 46 - Efetuar qualquer procedimento médico sem o consentimento e o esclarecimento prévios do paciente ou de seu responsável legal, salvo em iminente perigo de vida;

Art. 48 - Exercer sua autoridade de maneira a limitar o direito do paciente de decidir livremente sobre sua pessoa ou seu bem estar;

Art. 56 - Desrespeitar o direito do paciente de decidir livremente sobre a execução de práticas diagnósticas ou terapêuticas, salvo em caso de iminente perigo de vida.

Art. 103 - Revelar segredo profissional referente a paciente menor de idade, inclusive a seus pais ou responsáveis legais, desde que o menor tenha capacidade de avaliar seu problema e de conduzir-se por seus próprios meios para solucioná-lo, salvo quando a não revelação possa acarretar dano ao paciente.

Já o Código Civil determina que:

Art. $3^{\circ}$ - São absolutamente incapazes de exercer pessoalmente os atos da vida civil: I - os menores de dezesseis anos;

Art. $4^{\circ}$ - São incapazes, relativamente a certos atos, ou à maneira de os exercer: I - os maiores de dezesseis e menores de dezoito anos;

Art. $5^{\circ}$ - A menoridade cessa aos dezoito anos completos, quando a pessoa fica habilitada à prática de todos os atos da vida civil. (Manole, 2004: 200-201) 
Porém, esse artigo $5^{\circ}$ abre um facultativo quando diz em seu parágrafo único que:

Cessará, para os menores, a incapacidade:

I - pela concessão dos pais, ou de um deles na falta do outro, mediante instrumento público, independente de homologação judicial, ou por sentença do juiz, ouvido o tutor, se o menor tiver dezesseis anos completos;

II - pelo casamento;

III - pelo exercício de emprego público efetivo;

IV - pela colação de grau em curso de ensino superior;

$\mathrm{V}$ - pelo estabelecimento civil ou comercial, ou pela existência de relação de emprego, desde que, em função deles, o menor com dezesseis anos completos tenha economia própria. (Manole, 2004: 201)

O mesmo Código Civil determina, no artigo $3^{\circ}$, que os menores de 16 anos são considerados absolutamente incapazes porque, devido à idade, não atingiram o discernimento para distinguir o que podem ou não fazer, o que lhes é conveniente ou prejudicial e, por isso, para a validade de seus atos, será preciso que estejam representados por seu pai, sua mãe ou por seu tutor. E o artigo $4^{\circ}$ coloca como incapazes relativos os adolescentes entre 16 e 18 anos. Porém, cabe aqui o comentário de que cada vez fica mais patente a necessidade de um entendimento de como esse conceito deve, sempre que possível, ser entendido dentro de uma análise contextual, na qual se considere o grau de maturidade e de discernimento do adolescente, independentemente da visão simplista de sua idade cronológica.

Se na deficiência mental não é considerada a idade cronológica, no oposto, quando se tem uma grande capacidade de discernimento, também 
não se deveria considerar hermeticamente somente essa idade cronológica. Esse raciocínio é considerado no artigo $5^{\circ}$ nos incisos II e V, quando relata que o ato de casar e formar família, bem como o de ter economia própria e reger sua própria pessoa e patrimônio dá a capacidade de discernimento necessária para tirar de outrem a responsabilidade sobre o adolescente (Manole, 2004).

No ECA (1991) é determinado, em seu Capítulo II - "Do Direito à Liberdade, ao Respeito e à Dignidade", que:

Art. 15 - A criança e o adolescente têm direito à liberdade, ao respeito e à dignidade como pessoas humanas em processo de desenvolvimento e como sujeitos de direitos civis, humanos e sociais garantidos na Constituição e nas leis.

Art. 16 - O direito à liberdade compreende os seguintes aspectos: (...) II - opinião e expressão; III - crença e culto religioso (...).

Art. 17 - O direito ao respeito consiste na inviolabilidade da integridade física, psíquica e moral da criança e do adolescente, abrangendo a preservação da imagem, da identidade, da autonomia, dos valores, idéias e crenças, dos espaços e objetos pessoais.

Art. 18 - É dever de todos velar pela dignidade da criança e do adolescente, pondo-os a salvo de qualquer tratamento desumano, violento, aterrorizante, vexatório ou constrangedor.

A pessoa autônoma é aquela que tem liberdade de pensamento e é livre de coações internas e externas para escolher as alternativas que lhe são apresentadas (Muñoz \& Fortes, 1998). Existe um entendimento de que o respeito ao ser humano deva ser o princípio maior, do qual seriam originados todos os demais postulados éticos que norteariam todas as ações envolvendo os seres humanos. Logo, qualquer ação que desrespeite a vontade de uma pessoa poderá ser condenável eticamente. O endosso a essa premissa faz com que se conclua que só vai deixar de haver esse respeito à autonomia 
quando um dos elementos da relação estiver completamente incapacitado de decidir. Isso fica exemplificado nas situações de: 1) incapacidade de receber as informações; 2) não conseguir compreender e avaliar as informações; 3) estar impedido de decidir.

A Constituição Brasileira (Muñoz \& Fortes, 1998) assegura o direito à autonomia a todos os cidadãos, já que determina que ninguém pode ser obrigado a fazer ou a deixar de fazer alguma coisa, senão em virtude da lei. O Código Penal (apud Muñoz \& Fortes, 1998) exige o respeito a esse direito ao punir, no artigo 146, aquele que constranger outrem a fazer o que a lei não manda ou a deixar de fazer o que a lei manda. Porém, essa mesma legislação penal admite uma exceção a essa autonomia quando se tratar de iminente risco de vida ou para evitar suicídio: nessas situações, o constrangimento deixa de ser crime. Não deve ser esquecido nunca que o exercício da autonomia procura dar à pessoa o direito à vida e não sobre a vida; a ela é dada autonomia para viver, mas não para morrer. Em contrapartida, há que se ressaltar que o consentimento do paciente não descriminaliza a conduta médica quando houver tipificação legal para a mesma.

Cabe salientar que, não sendo um direito absoluto, a autonomia do paciente poderá vir a confrontar-se com a do médico ou de outro profissional da saúde que, por razões éticas, podem se opor aos desejos do paciente de realizar certos procedimentos, como eutanásia ou aborto, mesmo que haja amparo legal ou deontológico para tais ações: são as razões de consciência, que também devem ser consideradas por serem de foro íntimo do profissional, tendo este a prerrogativa de não efetivar a ação caso seja contrária aos seus preceitos éticos ou morais. O Código de Ética Médica (1988) garante ao médico, no artigo 28, o direito de: "Recusar a realização de atos médicos que, embora permitidos por lei, sejam contrários aos ditames de sua consciência".

Já houve exemplo dessa situação, noticiada na imprensa e avaliada à época por órgãos ligados à ética e à legislação, em um caso de gravidez com anencefalia, no qual a grávida manifestou desejo de interromper a gravidez. A Justiça entendeu que a demanda era procedente, concedeu o 
direito ao aborto, mas houve dificuldade em conseguir o hospital e a equipe médica que o executasse exatamente com base nessas razões de consciência.

Fica claro que a normalização legal e ética hoje existente caracteriza a autonomia como um princípio e um direito relativos, tanto para o paciente quanto para o médico ou a equipe de saúde, deixando entender que tanto civil quanto eticamente existe um cuidado e um compromisso com o bem maior do paciente, que é sua vida. Dentro dessa relatividade é que a Bioética vem procurando a aplicação da ética na prática diária da medicina, propondo uma maneira de análise de cada situação, respeitando-se os valores, mas tentando uma adequação na qual os conflitos oriundos dessa prática possam ser resolvidos a contento das partes envolvidas.

\section{Bioética em Pediatria e o Consentimento Livre e Esclarecido}

O consentimento esclarecido é um assunto de tamanha importância para a prática médica, especialmente com crianças e adolescentes, que merece alguns comentários a seu respeito, ainda que existam muitas dúvidas sobre como interpretar a legislação existente para o assunto.

A argumentação apresentada até agora dá respaldo e fundamentação para que o consentimento esclarecido seja valorizado e sua prática estimulada, pois é fundamental que o paciente, ou seu responsável legal, esteja totalmente ciente da situação, do prognóstico e da conduta disponível e apropriada para o caso, para que, em conjunto com o médico ou a equipe médica, seja então tomada a decisão propedêutica ou terapêutica melhor indicada.

Cabe aqui fazer uma diferenciação entre consentimento informado e esclarecido. A semântica dos termos não deixa dúvidas sobre a vantagem de esclarecer em vez de somente informar - o esclarecimento detalhado, em termos simples e de fácil entendimento pelo paciente, cria um vínculo de parceria muito forte entre médico e paciente para que, a partir daí, as decisões possam ser tomadas em conjunto, seguindo a orientação técnica do médico, que é o profissional detentor do conhecimento e do saber. É importante que, nesse processo, a pessoa receba uma explicação minuciosa 
sobre o procedimento, compreenda a informação, aja de maneira voluntária, tenha competência para decidir e dê seu consentimento ou não.

Já o consentimento 'informado' pressupõe tão-somente a passagem de informação do caso e suas características sem que abra o canal bidirecional de comunicação, o qual dá chance ao paciente de tirar suas dúvidas, fazer seus questionamentos e poder decidir, em conjunto, pelo caminho que quiser seguir, dentro das normas éticas e jurídicas. A informação pressupõe uma ação unidirecional e passiva, enquanto que o esclarecimento pressupõe ação bidirecional e ativa. A pessoa pode ser informada, o que não significa que esteja esclarecida, caso não compreenda as informações recebidas, principalmente se não forem em termos adaptados à sua realidade psicossocial.

É importante ressaltar, ainda, que o consentimento esclarecido deve ser contextualizado e, portanto, renovável e revogável. Um bom exemplo para essa afirmação é o consentimento para pesquisa com seres humanos, pois a qualquer momento o sujeito da pesquisa, ou seu responsável legal, pode decidir pela interrupção de sua participação. Em relação à pesquisa com seres humanos envolvendo crianças e adolescentes, há normas vigentes. Entre elas, a diretriz 5 das Diretrizes Internacionais do Council for International Organizations of Medical Sciences (CIOMS, 1993) estabelece que:

- Os pais ou representantes legais devem dar um consentimento por procuração;

- O consentimento de cada criança deve ser obtido na medida da sua capacidade;

- A recusa da criança em participar da pesquisa deve sempre ser respeitada, a menos que, de acordo com o protocolo de pesquisa, a terapia que a criança receberá não tenha qualquer alternativa medicamente aceitável.

Já o Conselho Nacional dos Direitos da Criança e do Adolescente (Conanda, 1995) preconiza a respeito dos direitos da criança e do adolescente hospitalizado: "Direito de não ser objeto de ensaio clínico, provas 
diagnósticas e terapêuticas, sem consentimento informado de seus pais ou responsáveis e o seu próprio, quando tiver discernimento para tal”. Na prática clínica, também deve ser observada essa temporalidade do consentimento esclarecido, já que as decisões devem ser revalidadas à medida que evolui o caso, com novas necessidades propedêuticas e terapêuticas.

\section{A Autonomia da Criança e do Adolescente}

Segundo Leone (1998), conceitualmente, a análise do respeito à autonomia de uma criança ou de um adolescente só tem sentido se for conduzida a partir do conhecimento da evolução de sua competência nas diferentes idades. Há que se abrir mão do paternalismo que respalda o conceito de que a criança e o adolescente são seres incapazes e que, por isso, os adultos fazem tudo o tempo todo por eles, visando ao seu bemestar e a benefícios, sempre imbuídos das melhores intenções. O risco implícito nessa visão tem relação com o vazio conceitual sobre o que é o melhor para os interesses da criança e do adolescente, deixando essa interpretação em aberto e sujeita às considerações de quem tem, legalmente, o poder de decidir em nome deles.

O limite da autonomia deve, portanto, ter uma avaliação contextual pela qual seja valorizado o momento de desenvolvimento em que se encontra a criança e o adolescente, lembrando que esse é um processo dinâmico em que as habilidades e capacidades adquiridas e vivências são incorporadas dentro de uma evolução constante. Como essa evolução tem parâmetros conhecidos, passa até a existir uma certa previsibilidade nas modificações que ocorrerão.

Não se deve criar estereótipos, já que a individualidade desse ser em formação faz com que cada um seja único, mesmo que cronologicamente da mesma idade que outros. O ser humano cresce e se desenvolve como fruto de fatores intrínsecos (congênitos e genéticos) e extrínsecos (socioculturais). E isso tem reflexo na formação de sua inteligência e de sua capacidade de discernimento, o que lhe dá competência para tomar 
decisões legítimas, independentemente das normas legais vigentes referentes à idade.

O ser humano em seu desenvolvimento na infância e adolescência, pode tomar decisões baseadas no medo do desconhecido ou ditadas por um capricho da vontade ou, ainda, como fruto de uma reflexão amadurecida. E essa grande variação de fatores desencadeantes é que traz à tona toda a dificuldade envolvida quando se quer analisar a competência para decidir.

O que os pais ou responsáveis e os médicos ou a equipe devem considerar é a aplicação da legislação em consonância com a análise da autonomia da criança e do adolescente, procurando identificar se o mesmo já adquiriu habilidade para entender as informações, a capacidade de realizar escolhas e o discernimento para avaliar o risco-benefício e os danos conseqüentes a uma decisão tomada. Deve ser incentivada a participação da criança e do adolescente na obtenção do consentimento esclarecido em conjunto com a família: a validade moral para tal ação virá à medida que seja adequado o processo ao estágio de desenvolvimento biopsicossocial dos mesmos (Goldin, 2004).

Essa postura na condução dos conflitos vem exatamente mostrar o amadurecimento da sociedade no entendimento dessa fase do desenvolvimento, conhecendo suas características, suas necessidades e expectativas, estabelecendo um canal de comunicação para que as decisões sejam, dentro do permitido e possível, tomadas em conjunto com o interessado, que é a criança ou o adolescente.

\section{ReferênClas BiBliOGRÁfiCAS}

CÓDIGO DE ÉTICA MÉDICA. Resolução CFM n. 1.246/88, de 8 jan. 1988. (D.O.U., 26 jan. 1988). Disponível em: http:// www.portalmedico.org.br/codigo_etica/codigo_etica.asp?portal=. Acesso em: 15 mar. 2004.

CONSELHO NACIONAL DOS DIREITOS DAS CRIANÇAS E DOS ADOLESCENTES (CONANDA). Resolução n. 41, de 13 out. 1995 (D.O.U. Seção 1, 17 out. 1995). 
COUNCIL FOR INTERNATIONAL ORGANIZATIONS OF MEDICAL SCIENCES (CIOMS). Diretrizes Éticas Internacionais para a Pesquisa Envolvendo Seres Humanos. Genebra: OMS, 1993. Disponível em: http:// www.bioetica.ufrgs.br/cioms.htm. Acesso em: 14 fev. 2004.

ESTATUTO DA CRIANÇA E DO ADOLESCENTE (ECA). Brasília: Ministério da Saúde, Projeto Minha Gente, 1991.

GOLDIM, J. R. Princípio do respeito à pessoa ou da autonomia. Disponível em: http://www.bioetica.ufrgs.br/autonomi.htm. Acesso em: 23 dez. 2004.

KIPPER, D. J. \& CLOTET, J. Princípios da beneficência e não-maleficência. In: IBIAPINA, S. F. C.; GARRAFA, V. \& OSELKA, G. (Orgs.) Iniciação à Bioética. Brasília: Conselho Federal de Medicina, 1998.

KIPPER, D. J et al. Uma introdução à bioética. Temas de Pediatria Nestlé 2002, n. 73. Brasil: Nestlé, 2002.

LEONE, C. A criança, o adolescente e a autonomia. Bioética, 6. Disponível em: http://www.portalmedico.org.br/revista/ind1v6.htm. Acesso em: 27 out. 2003, 1998.

MANOlE, EDIT. JUR. Constituição Federal, Código Civil (2002/1916), Código de Processo Civil, Código Penal, Código de Processo Penal, legislação complementar fundamental (Coord. da revisão: Amorim J. R. N). Baruaru: Manole, 2004.

MUÑNOZ, D. R. \& FORTES, P. A. C. O princípio da autonomia e o consentimento livre e esclarecido. In: IBIAPINA, S. F. C.; GARRAFA, V. \& OSELKA, G. (Orgs.) Iniciação à Bioética. Brasília: Conselho Federal de Medicina, 1998.

SEGRE, M.; SILVA, F. L. \& SCHRAMM, F. R. O conceito histórico, semântico e filosófico do priníipio da autonomia. Bioética, 6: 15-23, 1998.

FUNDO DAS NAÇÕES UNIDAS PARA A INFÂNCIA (UNICEF). Indicadores sobre crianças e adolescentes, 2001 Disponível em: http:// www.unicef.org/brazil/sib2001/cap2.html. Acesso em: 19 jan. 2004. 
Formato: $16 \times 23 \mathrm{~cm}$

Tipologia: Carmina Lt BT

Carleton

Papel: Pólen Bold $70 \mathrm{~g} / \mathrm{m}^{2}$ (miolo)

Cartão Supremo $250 \mathrm{~g} / \mathrm{m}^{2}$ (capa)

Fotolitos: Laser vegetal (miolo)

Ace Digital Ltda. (capa)

Impressão e acabamento: Imprinta Gráfica e Editora Ltda.

Rio de Janeiro, junho de 2005.

Não encontrando nossos títulos em livrarias, contactar a EDITORA FIOCRUZ:

Av. Brasil, 4036 - $1^{\circ}$ andar - sala 112 - Manguinhos

21040-361 - Rio de Janeiro - RJ

Tel.: (21) 3882-9039 e 3882-9041

Telefax: (21) 3882-9006

e-mail: editora@fiocruz.br

http://www.fiocruz.br/editora 